Record of Decision

\title{
Record of Decision for Tank Farm Soil and INTEC Groundwater
}

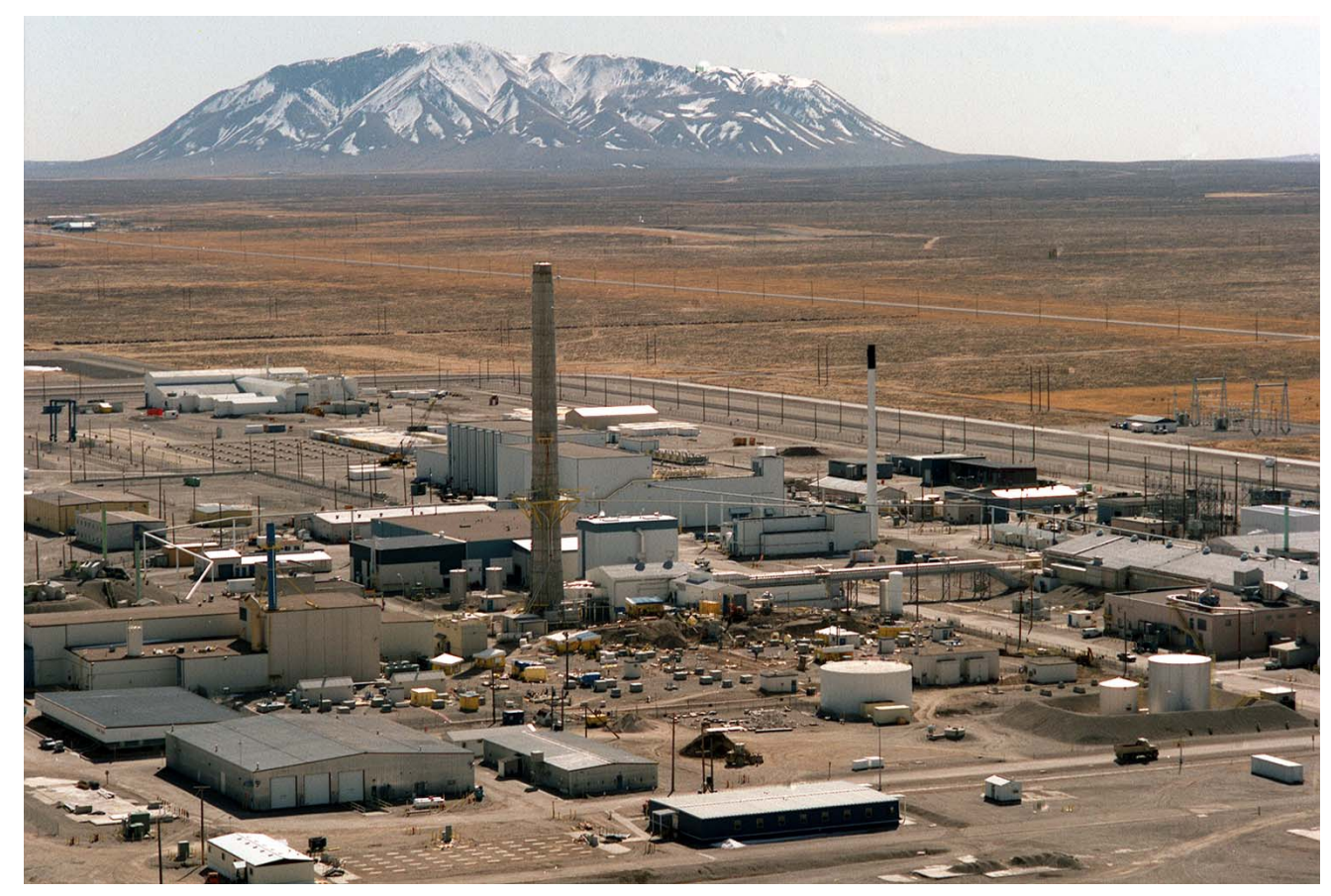

Operable Unit 3-14

Idaho Cleanup Project

Idaho National Laboratory Site

Idaho Falls, Idaho 
DOE/ID-11296

Revision 0

\section{Record of Decision for Tank Farm Soil and INTEC Groundwater}

May 2007

Prepared for the 



\section{PART 1: DECLARATION}

\section{SITE NAME AND LOCATION}

Waste Area Group 3, Operable Unit 3-14, Tank Farm Soil and INTEC Groundwater

Idaho National Laboratory Site, Scoville, Idaho

CERCLIS ID No. 4890008952; CERCLA Site ID No. 1000305

\section{STATEMENT OF BASIS AND PURPOSE}

This decision document presents the selected remedy for Operable Unit (OU) 3-14 tank farm soil and groundwater at the Idaho Nuclear Technology and Engineering Center (INTEC), which is located on the Idaho National Laboratory (INL) Site. The tank farm was initially evaluated in the OU 3-13 Record of Decision (ROD), and it was determined that additional information was needed to make a final decision. Additional information has been obtained on the nature and extent of contamination in the tank farm and on the impact to groundwater. The selected remedy was chosen in accordance with the Comprehensive Environmental Response, Liability and Compensation Act of 1980 (CERCLA) (42 USC 9601 et seq.), as amended by the Superfund Amendments and Reauthorization Act of 1986 (Public Law 99-499) and the National Oil and Hazardous Substances Pollution Contingency Plan (40 CFR 300). The selected remedy is intended to be the final action for tank farm soil and groundwater at INTEC.

The U.S. Department of Energy Idaho Operations Office (DOE-ID) is the lead agency for this decision. The U.S. Environmental Protection Agency (EPA) Region 10 approves this decision and the Idaho Department of Environmental Quality (DEQ) concurs. EPA and DEQ have participated in the evaluation and selection of remedies for OU 3-14 sites and groundwater, including the no action and institutional control decisions. The basis for decisions is established in this ROD and documented in the Administrative Record file for OU 3-14.

\section{ASSESSMENT OF SITE}

The response action selected in this ROD is necessary to protect the public health, welfare, or the environment from actual or threatened releases of hazardous substances into the environment. Such a release or threat of release may present an imminent and substantial endangerment to public health, welfare, or the environment. The remedial actions selected in this ROD are designed to reduce the potential threats to human health and the environment to acceptable levels. In addition, DOE-ID, EPA, and DEQ (the Agencies) have determined that no action is necessary under CERCLA to protect public health, welfare, or the environment at 16 sites located outside the tank farm boundary.

\section{DESCRIPTION OF THE SELECTED REMEDY}

The tank farm remedial action is part of the Idaho Cleanup Project at the INL Site. A comprehensive ROD was completed for INTEC (OU 3-13) in 1999 (DOE-ID 1999a). As part of the OU 3-13 ROD, the Agencies determined that they needed more information and created OU 3-14 to conduct further investigations and select a final remedy for tank farm soil and INTEC groundwater. The OU 3-14 remedy supersedes the OU 3-13 interim actions and is integrated with the OU 3-13 final actions. The OU 3-14 remedy is independent of, but coordinated with, the ongoing INTEC operations and the Tank Farm Facility closure being performed under the State of Idaho Hazardous Waste Management Act/Resource Conservation and Recovery Act. 
The major threats posed by contaminated soil inside the tank farm boundary are direct radiation exposure to workers and internal exposure to biota (such as insects and birds) from radionuclides in the soil. The major threat posed by groundwater is potential ingestion of radionuclide-contaminated water from a portion of the Snake River Plain Aquifer under the INTEC facility in the year 2095 (assumed start of hypothetical residential scenario) and beyond. Although the OU 3-13 ROD considered tank farm soil principal threat waste due to direct radiation exposure and potential leaching and transport of contaminants to the perched water or the Snake River Plain Aquifer, the ROD required further study of tank farm soil under OU 3-14 in order to make a final remedial decision. Further investigation under OU 3-14 has determined, using EPA guidance (EPA 1991), that the soil is not principal threat waste. This determination was made because the residual contamination in the soil is not highly mobile (cesium-137) or no longer mobile (residual strontium-90 in the soil) and not a threat to the Snake River Plain Aquifer. Treatment of the soil was considered in the OU 3-14 Feasibility Study but not selected based on (1) the effectiveness of soil containment, (2) the protectiveness provided by containment for human health and the environment, (3) the other CERCLA evaluation criteria, and (4) the difficulty of treatment due to the complexity of the site and the limitations of treatment technologies for radionuclides in soil. OU 3-14 determined that the threat to the Snake River Plain Aquifer is from the strontium-90 that migrated over 30 years ago to the perched water system, which is not principal threat waste by definition (EPA 1991). The remedy is designed to reduce downward transport of strontium-90 out of the perched water system to protect the Snake River Plain Aquifer.

The purposes of the selected remedy are to (1) contain contaminated soil as the radionuclides decay in place, (2) isolate current and future workers and biological receptors from contact with contaminated soil, and (3) restore the portion of Snake River Plain Aquifer contaminated by INTEC releases to Idaho Ground Water Quality standards (same as maximum contaminant levels) by reducing water infiltration through strontium-90 contaminated perched water and interbeds. In addition, the remedy will prevent future drinking water wells from being drilled into the contaminated portion of the aquifer that is in and near the INTEC facility until such time as the water is restored to maximum contaminant levels or below.

The selected remedy for OU 3-14 consists of remedial actions for tank farm soil and groundwater and no action for a group of sites outside the tank farm. Major components of the selected remedy are summarized below, beginning with items that are common to all time periods (Items 1 through 4), and ending with items that are specific to a time period (Items 5 through 7):

1. Institutional controls will be implemented to prevent exposure to the contaminated soil and groundwater and prevent land uses that would be inconsistent with the selected remedy. The institutional controls include restrictions to (a) eliminate or minimize exposure to contaminated soil or groundwater; (b) limit disturbances of contaminated tank farm soil by non-CERCLA activities; (c) prohibit the use of the portion of the Snake River Plain Aquifer in proximity to INTEC that exceeds maximum contaminant levels; and (d) control drilling activities that could cause potential cross contamination between contaminated perched water and the Snake River Plain Aquifer. These controls will be included in the INL's Sitewide institutional controls plan.

2. Contaminant concentrations and water levels in perched water and Snake River Plain Aquifer indicator wells will be monitored in accordance with a long-term monitoring plan to assist in determining the effectiveness of the groundwater remedy and to ensure that the portions of the Snake River Plain Aquifer contaminated by INTEC releases will meet maximum contaminant levels by 2095 .

3. The selected remedy for 16 sites outside the tank farm boundary is no action under CERCLA. Three of these sites (CPP-125, CPP-126, and CPP-128) involved leaks or releases of nonradioactive, nonhazardous steam condensate or service wastewater and, therefore, require no 
action. The remaining 13 no action sites (CPP-102, CPP-103, CPP-104, CPP-105, CPP-106, CPP-107, CPP-108, CPP-109, CPP-110, CPP-113, CPP-114, CPP-115, CPP-116) are shallow injection wells associated with the steam system. Releases associated with these sites do not pose an unacceptable risk to human health or the environment based on unlimited use and unrestricted exposures and, therefore, do not require CERCLA remediation or implementation of institutional controls. Therefore, upon finalization of the no action decision in this ROD, the sites will exit the CERCLA process.

4. If historic releases to the environment are discovered after the ROD is implemented, this contamination will be addressed using the process the Agencies have established for evaluation and inclusion of new sites under the Federal Facility Agreement and Consent Order. Using this process, a newly identified release is evaluated and, if the contaminants are addressed in an existing ROD, the Agencies may determine that the site may be remediated under the existing ROD. These sites will undergo evaluation during the 5-year review process to assess whether the actions taken are sufficient to protect human health and the environment. To protect workers, the public, and the environment, the institutional controls for newly identified sites will be implemented using the controls in place for similar sites in the operable unit.

5. Prior to Tank Farm Facility closure, these major components will be implemented:

- Install and maintain a low-permeability pavement (or equivalent barrier to reduce infiltration) over the recharge control zone outside the tank farm with expanded drainage system to reduce infiltration of precipitation without interfering with ongoing INTEC operations and remediation activities. Direct water run-off toward lined ditches, which will divert it to an evaporation pond. As buildings and structures are removed through deactivation, decontamination, and decommissioning, extend the low-permeability pavement to maintain an infiltration-reducing barrier over the recharge control zone outside the tank farm.

- Maintain the Tank Farm Interim Action system per the Operations and Maintenance Plan until the selected remedy's drainage and water management system is expanded. Approval of the OU 3-14 Remedial Design/Remedial Action Work Plan, and expansion, completes the Tank Farm Interim Action.

- Implement and maintain additional recharge controls in northern INTEC to reduce anthropogenic and storm water recharge to the northern perched water zones.

6. Following Tank Farm Facility closure, these major components will be implemented:

- Install a low-permeability pavement (or equivalent barrier to reduce infiltration) over the north, central, and south tank farm to reduce infiltration of precipitation. Direct captured surface water run-off toward lined ditches, culverts, and lift station(s) for transport to the lined evaporation pond.

- $\quad$ Maintain the drainage system and low-permeability pavement over the recharge control zone to reduce infiltration of precipitation without interfering with ongoing INTEC cleanup operations.

- Maintain the recharge controls in northern INTEC to reduce anthropogenic and storm water recharge sources to the northern perched water zones. 
7. As part of and coordinated with INTEC facility closure, these major components will be implemented:

- Install a protective cover over the north tank farm. Use characterization results to design the protective cover (i.e., maintain the low-permeability pavement, excavate soil and replace with clean backfill and new low-permeability pavement or equivalent barrier to reduce infiltration, or extend the evapotranspiration cap with capillary biobarrier $[\mathrm{ET} / \mathrm{CB}]$ that is to be placed over the central area).

- Install an ET/CB over the central and south tank farm to protect workers from exposure.

- Monitor and maintain the ET/CB, low-permeability pavement, and drainage system to reduce infiltration of precipitation.

\section{Waste Management}

Soil and other media that have become contaminated by contact with sodium-bearing waste or high-level waste are contaminated media. The characteristics and concentrations of the contaminated soil and media have been altered over time due to transport through the subsurface, chemical and/or physical reaction with surrounding materials, and radioactive decay. Tank farm activities, such as construction, maintenance, and removal of these soils and media, have further modified contaminant concentrations. Contaminated soil and media that are disturbed and removed during remediation activities will be managed based on the actual radioactive and chemical characteristics and concentrations of the media.

Contaminated media from OU 3-14 activities, debris, sample equipment and residue, personal protective equipment, and other investigation- or remediation-derived waste can be disposed of in the Idaho CERCLA Disposal Facility, subject to meeting the facility's Waste Acceptance Criteria. This includes waste generated as a result of previous sampling activities under the OU 3-14 remedial investigation/feasibility study (known as investigation-derived waste). Waste from OU 3-14 remedial design/remedial action activities and investigation-derived waste will be temporarily consolidated within the Waste Area Group 3 area of contamination (described in the OU 3-13 ROD, DOE-ID 1999a).

This ROD also recognizes that OU 3-14 contaminated soil may be disturbed through maintenance or upgrade activities associated with INTEC operations before the final CERCLA remedy is fully implemented. The contaminated soil and media that are generated will be CERCLA remediation waste, because the removal and subsequent storage and disposal of contaminated soil represent progress toward cleanup and can, therefore, be disposed of in the Idaho CERCLA Disposal Facility and otherwise consolidated in accordance with CERCLA within the INL Site.

\section{STATUTORY DETERMINATIONS}

Statutory Requirements - The selected remedy attains the mandates of CERCLA $\S 121$ (42 USC 9621) and is protective of human health and the environment, complies with federal and state requirements that are applicable or relevant and appropriate to the remedial action, is cost-effective, and uses permanent solutions.

Statutory Preference for Treatment-The National Oil and Hazardous Substances Pollution Contingency Plan expresses a preference for remedies that use permanent solutions and alternative treatment technologies to the maximum extent possible to reduce toxicity, mobility, and volume. The remedy in this OU does not employ treatment, which is statutorily preferred to the extent practical, as a principal element of the remedy for the following reasons: (1) most of the contaminants of concern are 
radionuclides that cannot be destroyed through treatment, (2) a cost-effective method to separate cesium-137 from the soil is not available, and (3) the selected remedy, containment, meets EPA's preference for sites where treatment is impractical.

Five-Year Review Requirement - Land use and groundwater restrictions are necessary because the selected remedy will result in contaminants remaining onsite in soil and groundwater at levels above those that allow for unlimited use and unrestricted exposure. A statutory review will be conducted within 5 years after startup of the remedial action to ensure that the remedy continues to provide adequate protection for human health and the environment. The 5-year review will evaluate such factors as contaminant migration from sites where contamination has been left in place, effectiveness of institutional controls, and overall effectiveness of the remedial actions. Five-year reviews will be conducted for remediated sites with institutional controls until it has been determined during a 5-year review that controls and reviews are no longer necessary. It is anticipated that the 5-year review for this operable unit (OU 3-14) will be combined with the comprehensive 5-year review for CERCLA response actions at the INL Site, as practical.

\section{RECORD OF DECISION DATA CERTIFICATION CHECKLIST}

The information listed below is included in the Decision Summary (Part 2) of this ROD:

- $\quad$ Contaminants of concern and their respective concentrations (see Sections 5.2.2, OU 3-14 2004

Soil Sampling Results; 5.6, Current Perched Water and Aquifer Contamination; and 7, Site Risks).

- $\quad$ Baseline risks represented by the contaminants of concern (see Section 7, Site Risks).

- $\quad$ Cleanup levels established for the contaminants of concern and the basis for the levels (see Section 9, Remediation Goals).

- $\quad$ No source materials constituting principal threats were encountered.

- $\quad$ Current and reasonably anticipated future land use assumptions and current and potential future beneficial uses of groundwater used in the baseline risk assessment and ROD (see Sections 4, Scope and Role of Response Action; 6, Current and Potential Future Site and Resource Uses; and 12.4, Expected Outcomes of the Selected Remedy).

- $\quad$ Potential land use and groundwater use that will be available at the site as a result of the selected remedy (see Section 12.4, Expected Outcomes of the Selected Remedy).

- $\quad$ Estimated capital, annual operations and maintenance, and total net present value costs; the discount rate; and the number of years over which the remedy cost estimates are projected (see Section 12.3, Estimated Cost for the Selected Remedy).

- $\quad$ Key factors that led to selecting the remedies (see Sections 7.5, Basis for Action, and 12.1, Summary of the Rationale for the Selected Remedy).

Additional information can be found in the Administrative Record for OU 3-14. 
Signature sheet for the Record of Decision for Tank Farm Soil and INTEC Groundwater at the Idaho National Laboratory, between the U.S. Department of Energy and the U.S. Environmental Protection Agency, with concurrence by the Idaho Department of Environmental Quality.

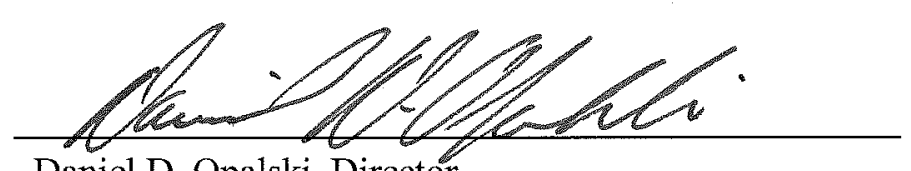

Daniel D. Opalski, Director

Office of Environmental Cleanup

U.S. Environmental Protection Agency

Region 10

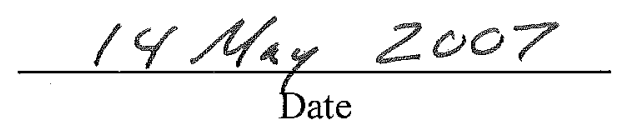


Signature sheet for the Record of Decision for Tank Farm Soil and INTEC Groundwater at the Idaho National Laboratory, between the U.S. Department of Energy and the U.S. Environmental Protection Agency, with concurrence by the Idaho Department of Environmental Quality.

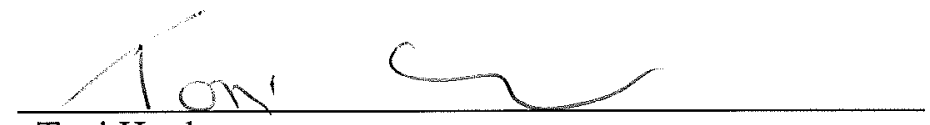

Toni Hardesty

Director

Idaho Department of Environmental Quality

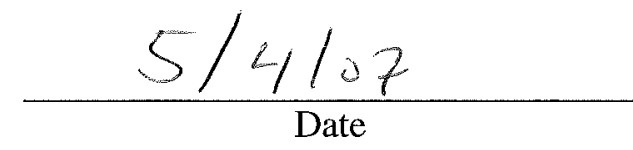


Signature sheet for the Record of Decision for Tank Farm Soil and INTEC Groundwater at the Idaho National Laboratory, between the U.S. Department of Energy and the U.S. Environmental Protection Agency, with concurrence by the Idaho Department of Environmental Quality.
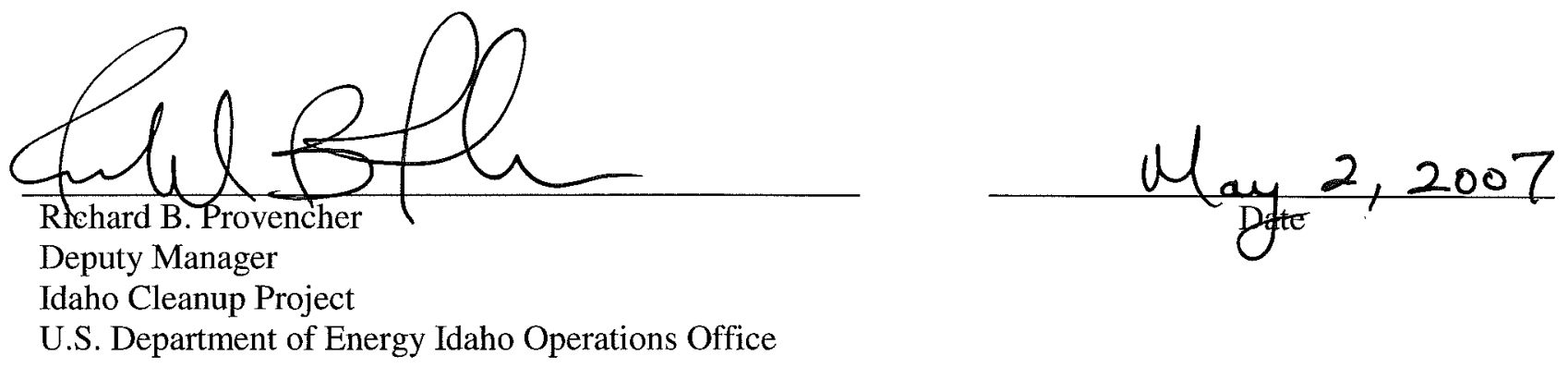

Idaho Cleanup Project

.S. Department of Energy Idaho Operations Office 


\section{CONTENTS}

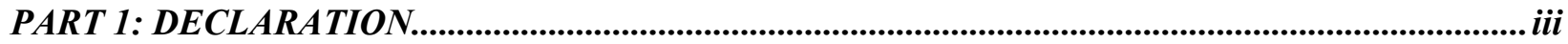

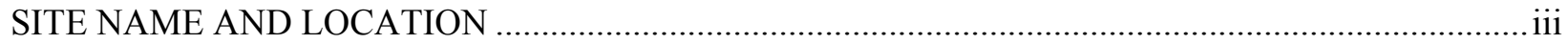

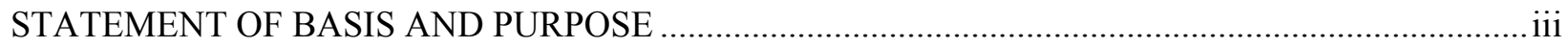

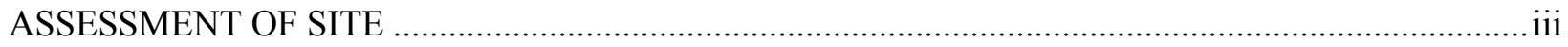

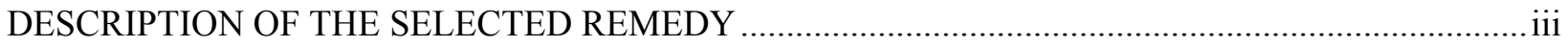

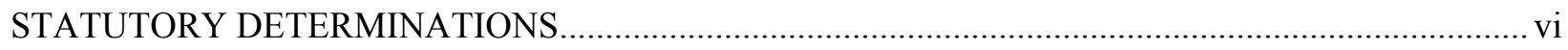

RECORD OF DECISION DATA CERTIFICATION CHECKLIST .................................................... vii

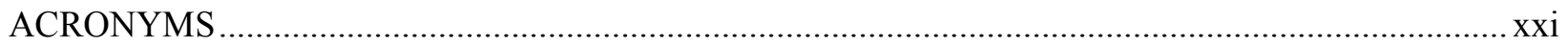

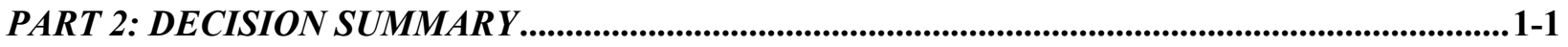

1. SITE NAME, LOCATION, AND BRIEF DESCRIPTION ....................................................... 1-1

2. SITE HISTORY AND ENFORCEMENT ACTIVITIES …................................................. $2-1$

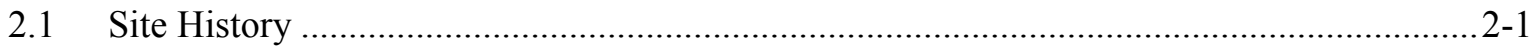

2.2 Regulatory Status of the Tank Farm Facility …............................................................. 2-1

2.3 Background of CERCLA Investigations, Remedial Actions, and Enforcement

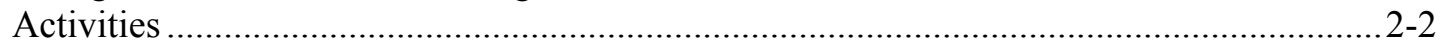

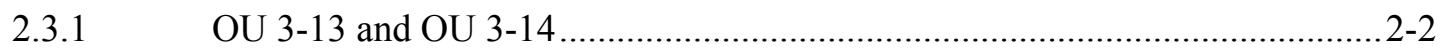

2.3.2 OU 3-13 Group 1, Tank Farm Soil ..............................................................2-3

2.3.3 OU 3-13 Group 2, Soils under Buildings and Structures ...............................2-4

2.3.4 OU 3-13 Group 3, Other Surface Soils .......................................................2-4

2.3.5 OU 3-13 Group 4, Perched Water Final Action...........................................2-4

2.3.6 OU 3-13 Group 5, Snake River Plain Aquifer Interim Action..........................2-4

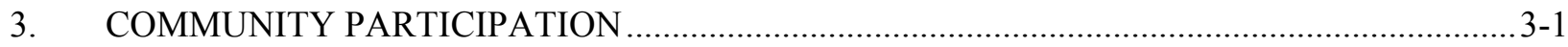

4. SCOPE AND ROLE OF RESPONSE ACTION …...............................................................

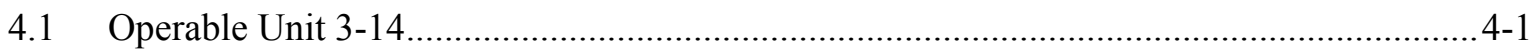

4.2 Coordination between Operable Units 3-13 and 3-14 ................................................4-4

4.3 Deactivation, Decontamination, and Decommissioning ................................................. 4-5

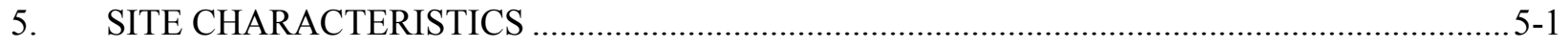

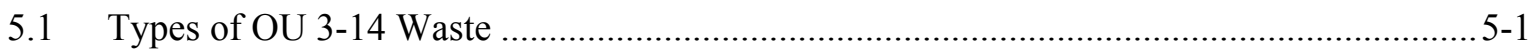




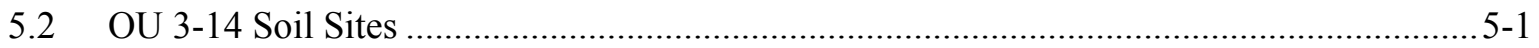

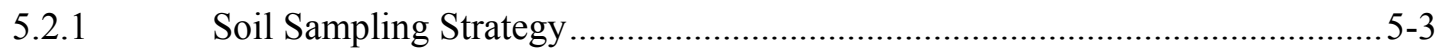

5.2.2 OU 3-14 2004 Soil Sampling Results .................................................. 5-5

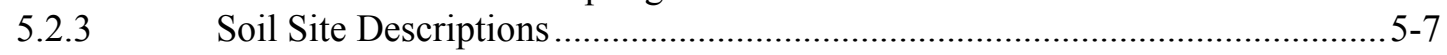

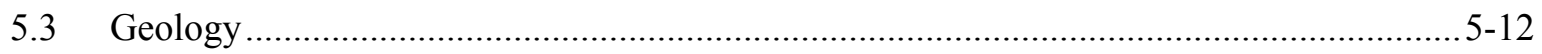

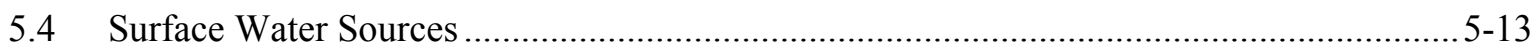

5.4.1 Big Lost River ........................................................................... $\quad$ 5-13

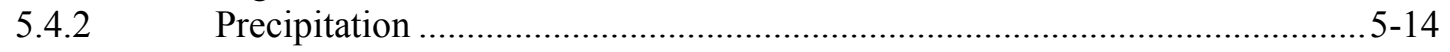

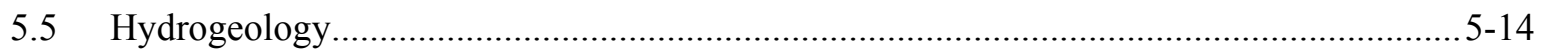

5.5.1 Northern Shallow Perched Water............................................................ 5-16

5.5.2 Northern Deep Perched Water ............................................................. 5-16

5.5.3 Snake River Plain Aquifer.................................................................. 5-16

5.6 Current Perched Water and Aquifer Contamination ................................................... 5-18

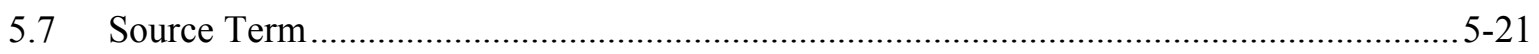

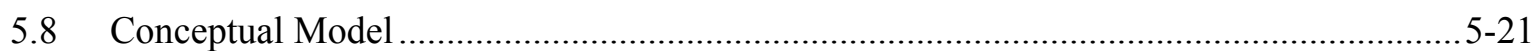

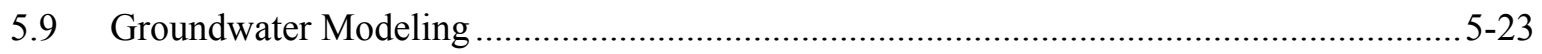

6. CURRENT AND POTENTIAL FUTURE SITE AND RESOURCE USES ...............................6-1

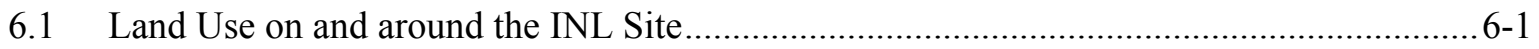

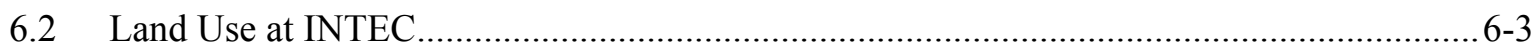

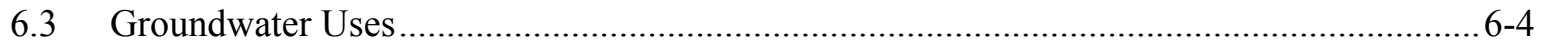

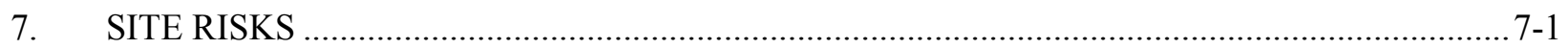

7.1 Summary of Human Health Risk Assessment ........................................................... 7-1

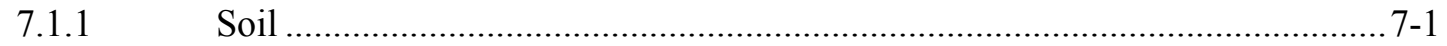

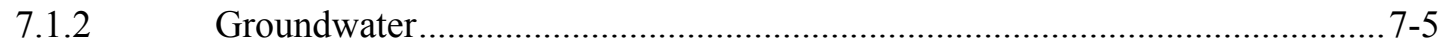

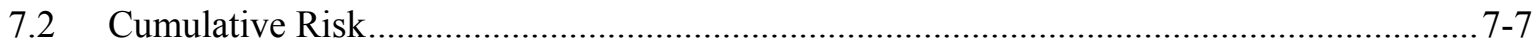

7.3 Cumulative Impacts from Non-CERCLA Residual Sources at INTEC............................. 7-7

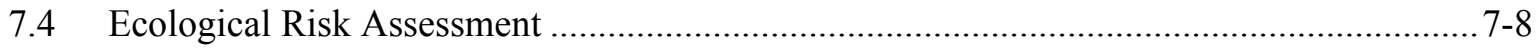

7.4.1 Ecological Risk Assessment Results ............................................................ 7-8

7.4.2 Summary of Results for the Ecological Risk Assessment ............................. 7-8

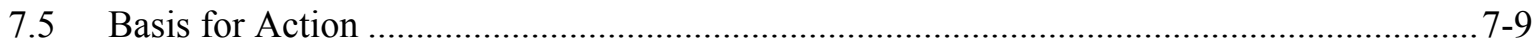




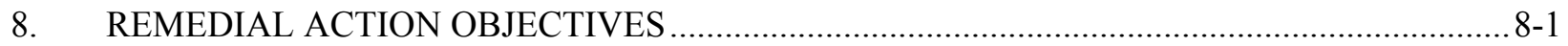

8.1 Remedial Action Objectives for OU 3-14 .......................................................... 8-1

8.2 Basis and Rationale for Remedial Action Objectives .................................................. 8-2

8.3 Risks Addressed by the Remedial Action Objectives..................................................... 8-2

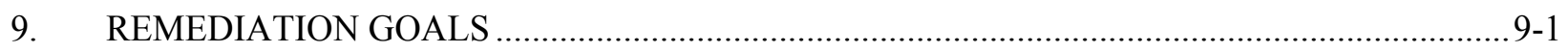

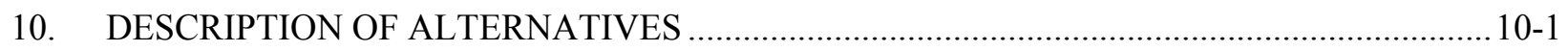

10.1 No Action Alternative ........................................................................................... 10-2

10.2 Alternative 1 - Limited Action ............................................................................. 10-2

10.3 Alternative 2 - Containment and Monitoring ......................................................... 10-3

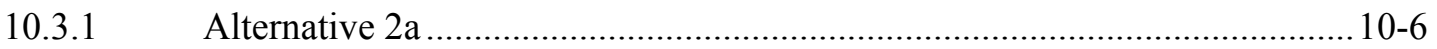

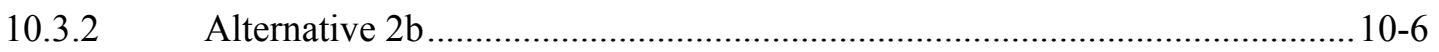

10.4 Alternative 3 - Hot Spot Removal, Containment, and Monitoring ................................. 10-6

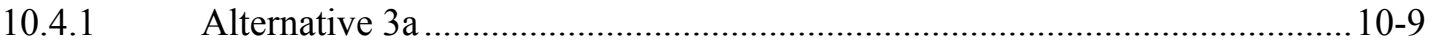

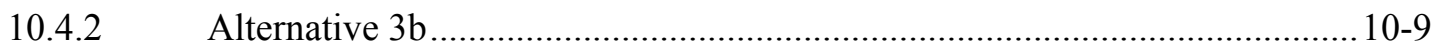

10.5 Alternative 4 - In Situ Hot Spot Treatment, Containment, and Monitoring ....................10-10

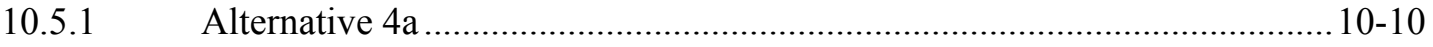

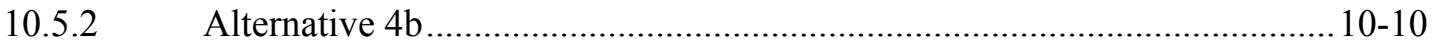

11. COMPARATIVE ANALYSIS OF ALTERNATIVES........................................................ 11-1

11.1 Overall Protection of Human Health and the Environment ...........................................11-1

11.2 Compliance with Applicable or Relevant and Appropriate Requirements ....................... 11-1

11.3 Long-Term Effectiveness and Permanence .......................................................... 11-5

11.4 Reduction of Toxicity, Mobility, and Volume through Treatment ................................ 11-6

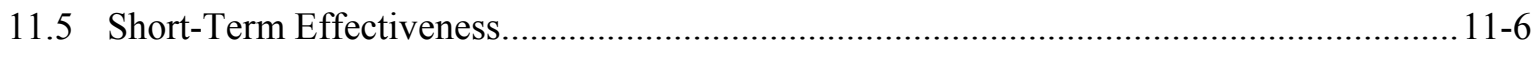

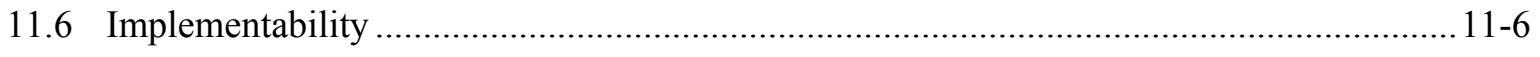

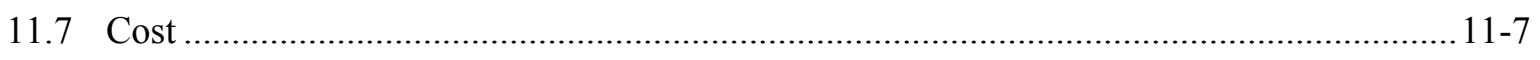

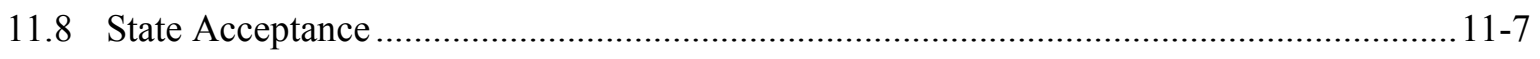

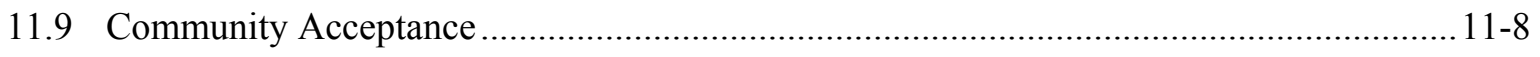


12.1 Summary of the Rationale for the Selected Remedy ................................................ 12-1

12.2 Description of the Selected Remedy …............................................................... 12-1

12.2.1 Components of the Selected Remedy Prior to Tank Farm Facility

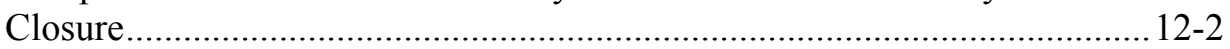

12.2.2 Remedy Components following Tank Farm Facility Closure ....................... 12-3

12.2.3 Remedy Components Coordinated with INTEC Facility Closure...................12-4

12.2.4 Institutional Controls Component of the Selected Remedy ..........................12-5

12.2.5 No Action Sites........................................................................... 12-7

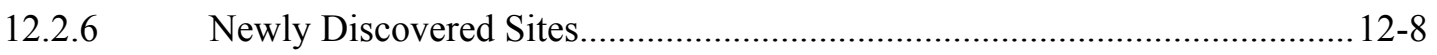

12.3 Estimated Cost for the Selected Remedy .............................................................. 12-8

12.4 Expected Outcomes of the Selected Remedy ....................................................... 12-11

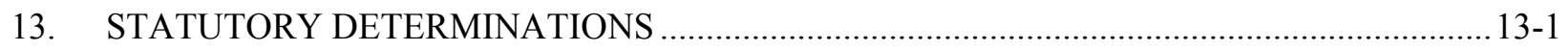

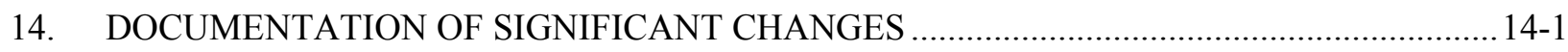

15. DECLARATION AND DECISION SUMMARY REFERENCES ......................................... 15-1

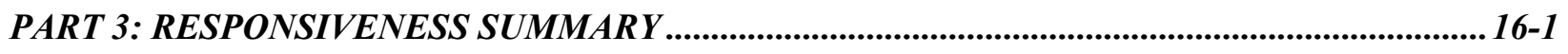

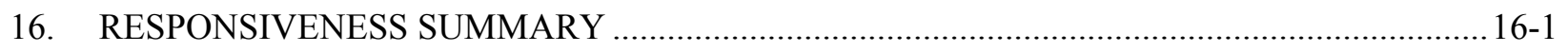

17. RESPONSIVENESS SUMMARY REFERENCES .......................................................... 17-1

\section{FIGURES}

\section{PART 2: DECISION SUMMARY}

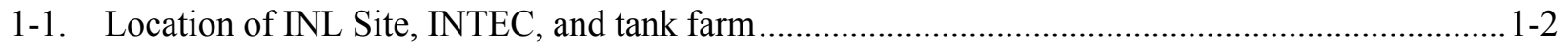

4-1. Tank farm — north, central, and south sections - shown with recharge control zone and

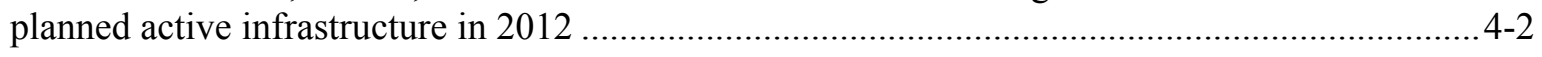

4-2. Industrial use area (soil institutional control area) and CERCLA sites ......................................4-3

5-1. OU 3-14 probeholes and sampling locations....................................................................

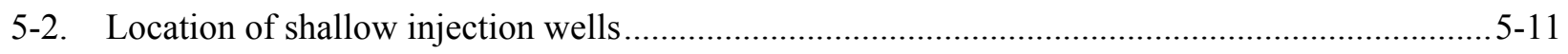

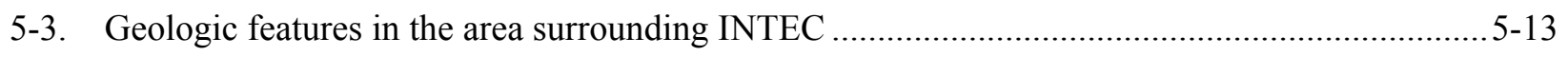

5-4. Big Lost River (upper left) and monitoring wells in the vicinity of INTEC ............................5-15

5-5. Approximate southern and eastern extent of northern shallow perched water in 2006...............5-17 
5-6. Distribution of Sr-90 in the SRPA in 2005 and initial groundwater and drilling institutional control (IC) area

5-7. Conceptual model of the subsurface showing the contamination beneath INTEC

5-8. Predicted SRPA Sr-90 plumes (in pCi/L) for the years 2005, 2022, 2077, and 2096 if no action is taken

5-9. Predicted SRPA Sr-90 plumes for the years 2049, 2077, 2096, and 2151 near INTEC if no action is taken

6-1. Land ownership and use in the vicinity of the Idaho National Laboratory Site

7-1. OU 3-14 conceptual site model showing groundwater source term, OU 3-14 and OU 3-13 contributing sources, release mechanisms, exposure pathways, and exposure routes and receptors for the OU 3-14 risk assessment

10-1. Alternative 2, Containment and Monitoring.

10-2. Conceptual design features of the low-permeability pavement.

10-3. Conceptual design features of the evapotranspiration cap with capillary biobarrier.

10-4. Cap extent for Alternatives 2 through 4 during and following facility operation

\section{TABLES}

\section{PART 2: DECISION SUMMARY}

5-1. OU 3-14 soil sites

5-2. Laboratory analyses of samples during the 2004 OU 3-14 field investigation

5-3. Fiscal Year 2004 soil sampling summary for contaminants of concern.

5-4. Maximum 2005 concentrations of COCs in perched water and the SRPA

5-5. Comparison of selected contaminant sources and their relative contributions

7-1. Current worker scenario risk assessment results for soil inside the tank farm boundary

7-2. Estimated total risk ${ }^{\mathrm{a}}$ to an unprotected worker from contaminated surface soil

7-3. Human health contaminants of concern summary (groundwater ingestion pathway) for all INTEC CERCLA sources (if no action taken)

7-4. Hazard quotients for internal exposure of ecological receptors to radionuclides from soil inside the tank farm boundary

9-1. Groundwater remediation goals for the year 2095 and beyond. $9-1$ 
9-2. Soil remediation goals for Cs-137 for various remedial decision dates

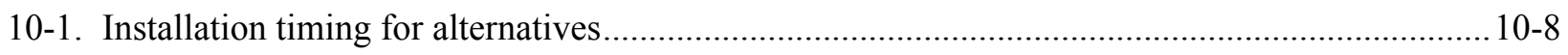

11-1. Detailed analysis summary for the OU 3-14 tank farm soil and groundwater ..........................11-2

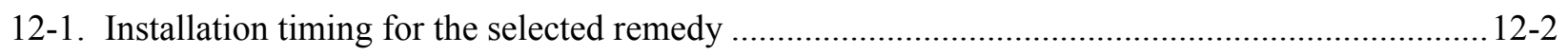

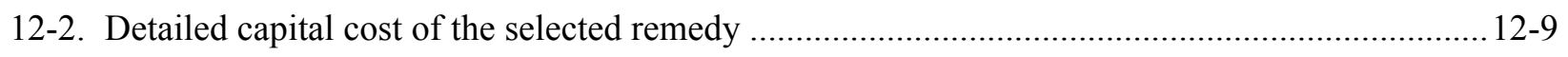

12-3. Detailed operations and maintenance and periodic cost of the selected remedy .......................12-10

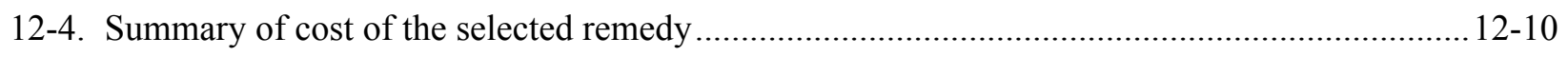

13-1. Summary of applicable or relevant and appropriate requirements for the selected remedy......... 13-2

PART 3: RESPONSIVENESS SUMMARY

16-1. Oral and written comments on the OU 3-14 Proposed Plan. 16-1 


\section{ACRONYMS}

AIP

ARAR

ARD

BLM

BLR

BRA

$\mathrm{CAB}$

CERCLA Comprehensive Environmental Response, Compensation and Liability Act

COC contaminant of concern

CPP

CRMP

DD\&D

DEQ

DOE

DOE-ID

EIS

EM

EPA

ERA

ESD

$\mathrm{ET} / \mathrm{CB}$

FFA/CO

FS

HEAST

HeTO
Agreement-In-Principle

applicable or relevant and appropriate requirement

Agreement to Resolve Dispute

Bureau of Land Management

Big Lost River

baseline risk assessment

Citizens Advisory Board

Chemical Processing Plant

Cultural Resource Management Plan

deactivation, decontamination, and decommissioning

Idaho Department of Environmental Quality

Department of Energy

Department of Energy Idaho Operations Office

Environmental Impact Statement

Environmental Management

Environmental Protection Agency

Ecological Risk Assessment

Explanation of Significant Differences

evapotranspiration cap with capillary biobarrier

Federal Facility Agreement and Consent Order

feasibility study

Health Effects Assessment Summary Table

Heritage Tribal Office 


\begin{tabular}{|c|c|}
\hline $\mathrm{HI}$ & Hazard Index \\
\hline HLW & high-level waste \\
\hline HLW\&FD FEIS & High-Level Waste \& Facilities Disposition Final Environmental Impact Statement \\
\hline HWMA & Hazardous Waste Management Act (Idaho) \\
\hline IC & institutional control \\
\hline $\mathrm{ICDF}$ & Idaho CERCLA Disposal Facility \\
\hline ICP & Idaho Cleanup Project \\
\hline ICPP & Idaho Chemical Processing Plant \\
\hline IDAPA & Idaho Administrative Procedure Act \\
\hline INL & Idaho National Laboratory \\
\hline INTEC & Idaho Nuclear Technology and Engineering Center \\
\hline MCL & maximum contaminant level \\
\hline MRDS & Monitoring Report/Decision Summary \\
\hline $\mathrm{NCP}$ & National Oil and Hazardous Substances Pollution Contingency Plan \\
\hline NEPA & National Environmental Policy Act \\
\hline NOV & Notice of Violation \\
\hline NPL & National Priorities List \\
\hline O\&M & operations and maintenance \\
\hline $\mathrm{OU}$ & operable unit \\
\hline PEW & process equipment waste \\
\hline PRG & preliminary remediation goal \\
\hline RAO & remedial action objective \\
\hline RCRA & Resource Conservation and Recovery Act \\
\hline $\mathrm{RCZ}$ & recharge control zone \\
\hline $\mathrm{RD} / \mathrm{RA}$ & remedial design/remedial action \\
\hline RG & remediation goal \\
\hline
\end{tabular}




$\begin{array}{ll}\text { RI } & \text { remedial investigation } \\ \text { ROD } & \text { Record of Decision } \\ \text { RTC } & \text { Reactor Technology Complex } \\ \text { SBW } & \text { sodium-bearing waste } \\ \text { SNF } & \text { spent nuclear fuel } \\ \text { SRPA } & \text { Snake River Plain Aquifer } \\ \text { TFF } & \text { Tank Farm Facility } \\ \text { TFIA } & \text { Tank Farm Interim Action } \\ \text { TMI } & \text { Three Mile Island } \\ \text { UCL } & \text { upper confidence limit } \\ \text { USGS } & \text { U.S. Geological Survey } \\ \text { WAG } & \text { waste area group } \\ \text { WCF } & \text { Waste Calcining Facility }\end{array}$


xxiv 


\section{PART 2: DECISION SUMMARY}

\section{SITE NAME, LOCATION, AND BRIEF DESCRIPTION}

Operable Unit (OU) 3-14 in Waste Area Group (WAG) 3 is located at the Idaho Nuclear Technology and Engineering Center (INTEC) on the Idaho National Laboratory (INL) ${ }^{\mathrm{a}}$ Site in southeastern Idaho. The Comprehensive Environmental Response, Compensation and Liability Act (CERCLA) (42 USC 9601 et seq.) identification number for the INL Site is 1000305.

The U.S. Department of Energy Idaho Operations Office (DOE-ID) is the lead agency responsible for the Idaho Cleanup Project's (ICP's) cleanup actions. The U.S. Environmental Protection Agency (EPA) Region 10 and the Idaho Department of Environmental Quality (DEQ) are support agencies and are responsible for regulatory oversight. DOE-ID, EPA, and DEQ are referred to collectively as the Agencies. EPA approves of the decision presented in this Record of Decision (ROD) and DEQ concurs. Both EPA and DEQ participated in the evaluation and selection of remedies for OU 3-14.

OU 3-14 consists of a group of soil sites located in and around the INTEC tank farm (see Figure 1-1), contaminated backfill within the tank farm boundary, and the underlying Snake River Plain Aquifer (SRPA) affected by INTEC releases. The OU 3-14 soil sites are located in an industrial land use area.

a. INL's name has changed over time. It began as the National Reactor Testing Station, was the Idaho National Engineering Laboratory from 1974 through 1996, and was the Idaho National Engineering and Environmental Laboratory from 1997 through January 2005, when it became Idaho National Laboratory. 


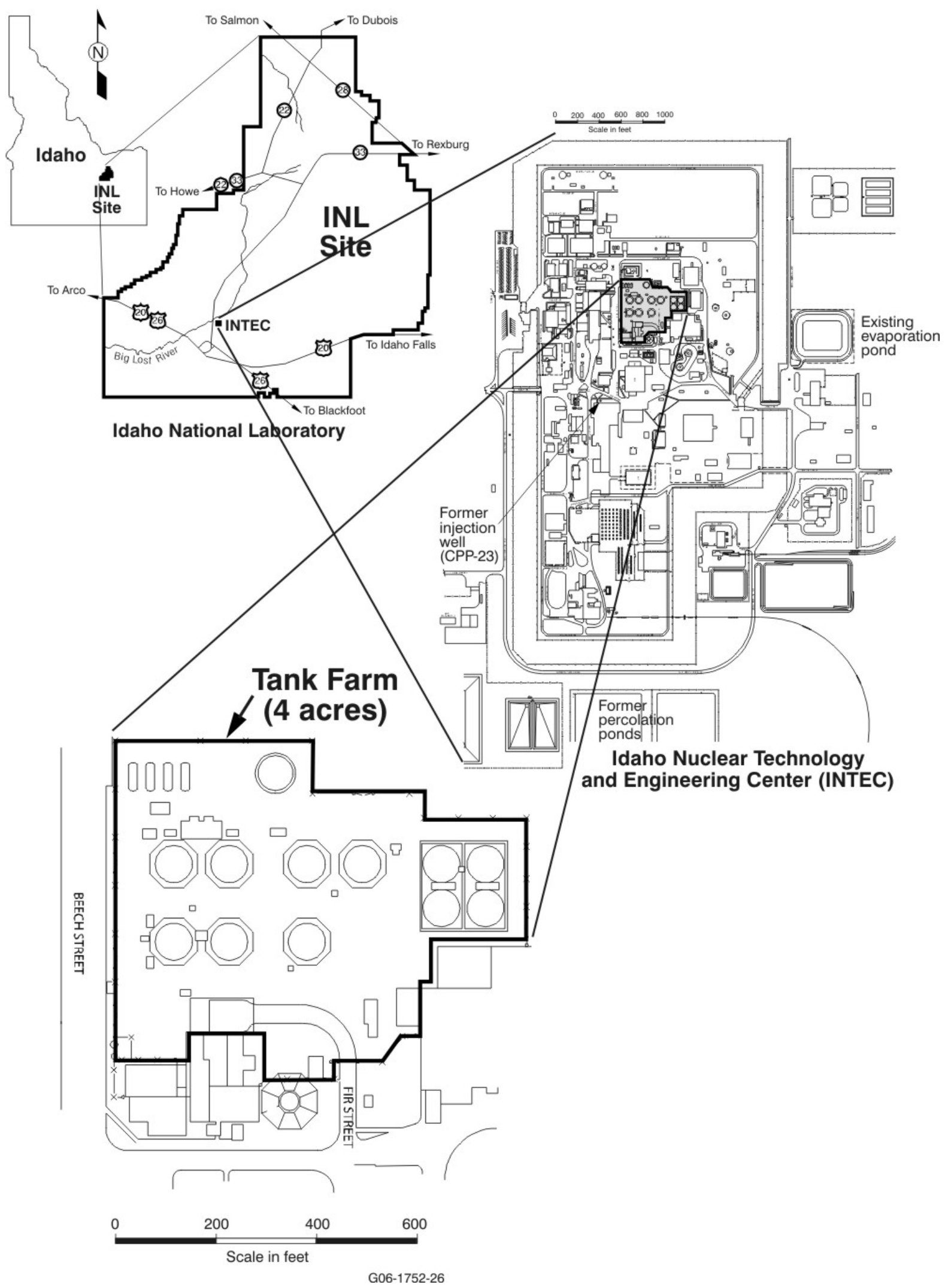

Figure 1-1. Location of INL Site, INTEC, and tank farm. 


\section{SITE HISTORY AND ENFORCEMENT ACTIVITIES}

This ROD selects a remedy for OU 3-14 CERCLA sites that are collocated within an operating Hazardous Waste Management Act (HWMA)/Resource Conservation and Recovery Act (RCRA) facility. The regulatory background under CERCLA is summarized below and includes a discussion of CERCLA, OU 3-13 (some OU 3-14 sites were originally in OU 3-13), and HWMA/RCRA as they pertain to the OU 3-14 remedy for the tank farm soil and INTEC groundwater. The OU 3-14 remedy for the contaminated soil surrounding the tanks is integrated with, and limited by, ongoing HWMA/RCRA closure activities and ongoing INTEC cleanup operations.

\subsection{Site History}

The tank farm was built beginning in the early 1950s and continuing into the mid-1960s. The tank farm is an integral part of the former Chemical Processing Plant (CPP, also called the Idaho Chemical Processing Plant [ICPP]), which is now INTEC. The Chemical Processing Plant was built to reprocess spent nuclear fuel (SNF) from reactors and recover and recycle uranium-235 (U-235) and other nuclear materials. Fuel reprocessing generated highly radioactive wastes. These wastes were stored underground in the tank farm in stainless-steel tanks. Most of these wastes have been removed from the tanks for treatment and have been concentrated in evaporators and/or converted into solids through a process called calcining.

From a CERCLA perspective, the term "tank farm" refers to the underground tanks used to store radioactive liquid wastes; the infrastructure used to transfer, monitor, and control the liquid wastes; and the surrounding soil within the tank farm boundary. Some of the piping and valves outside both the tanks and vaults leaked, contaminating soil, perched water, and groundwater. Some of the leaks were a result of flaws in piping or valve designs that were corrected during several major upgrades at the tank farm. The leaks and spills occurred mainly between 1954 and 1986. No leaks occurred from the tanks themselves.

Another source of contamination was the former INTEC injection well. It was used from the early 1950s to the mid-1980s for the routine discharge of service wastewater to the SRPA. The well was sealed and abandoned in 1989.

\subsection{Regulatory Status of the Tank Farm Facility}

The CERCLA tank farm soil and INTEC groundwater remedial action is independent of, and coordinated with, the operations and closure of the Tank Farm Facility (TFF). The TFF consists of eleven 300,000-gal and four 30,000-gal belowgrade stainless-steel tanks and the associated piping, valve boxes, encasements, and vaults. The hazardous components of wastes stored at the TFF are regulated through DEQ. The TFF is currently operating under HWMA/RCRA interim status as a hazardous waste management unit and is undergoing closure. As such, the requirements of 40 CFR 265, "Interim Status Standards for Owners and Operators of Hazardous Waste Treatment, Storage, and Disposal Facilities," apply to tank closure. These requirements apply to the 15 underground tanks, the tanks' contents, and ancillary equipment and piping.

The HWMA/RCRA closure of the tank system (emptying, cleaning, and grouting in place) is being performed in phases in accordance with a closure plan that is prepared for each phase. The final closure of the tank system will be complete when all of the tanks and ancillary equipment have been closed, including any post-closure requirements. A decision to close the tank system as a landfill or as a HWMA/RCRA clean closure will be determined during final closure (DOE-ID 2003), currently scheduled to be completed by December 31,2012. The TFF is also being closed in accordance with 
Department of Energy (DOE) Order 435.1 requirements for managing a radioactive waste storage facility and the Ronald W. Reagan National Defense Authorization Act (Public Law 108-375).

\subsection{Background of CERCLA Investigations, Remedial Actions, and Enforcement Activities}

This section of the ROD summarizes the CERCLA activities that are pertinent for OU 3-14.

\subsubsection{OU 3-13 and OU 3-14}

The INL Site was placed on the National Priorities List (NPL) of CERCLA hazardous substance release sites in 1989 (40 CFR 300) and became subject to the provisions of CERCLA $\S 120$ (42 USC 9620) governing remedial action at federal facilities. The former INTEC injection well was one of the sites that caused the INL Site to be listed on the NPL. In 1991, the Agencies signed a Federal Facility Agreement and Consent Order (FFA/CO) and Action Plan (DOE-ID 1991) governing CERCLA cleanups and HWMA/RCRA corrective actions on the INL Site. Under the terms of the CERCLA $\S 120$ as implemented through the FFA/CO, DOE will carry out the cleanup and fund all associated costs.

The FFA/CO placed all known CERCLA release sites at INTEC in OU 3-13 and required a comprehensive remedial investigation/feasibility study (RI/FS) for this OU. All known release sites within INTEC in 1997 were evaluated in the OU 3-13 Comprehensive RI/FS (DOE-ID 1997a, b). Ninety-five release sites were evaluated in the RI, 40 of which exceeded the soil remedial action objectives (RAOs) and were, therefore, further evaluated for remedial alternatives in the FS. In 1999, the Agencies signed the ROD for OU 3-13 (DOE-ID 1999a). The ROD divided the WAG 3 release sites requiring remedial action into groups according to shared characteristics or common contaminant sources. The groups that are relevant for this OU 3-14 ROD are

- $\quad$ Group 1: Tank Farm Soils

- $\quad$ Group 2: Soils Under Buildings and Structures

- Group 3: Other Surface Soils

- Group 4: Perched Water

- $\quad$ Group 5: Snake River Plain Aquifer.

As part of the OU 3-13 ROD, the Agencies determined that they needed more information before they could make a final remedial action decision. Information needed included

- The nature and extent of contamination in tank farm soil, including contaminated backfill, and in three soil sites outside the tank farm, as well as the impact of this contamination on groundwater

- Whether the former injection well, which was used from the early 1950s to 1986, was a continuing source of contamination to groundwater

- How a planned environmental impact statement (DOE 2002, 2005) for disposition of the waste in the TFF tanks would affect the decision for contaminated soil surrounding the tanks.

To address the need for the additional information, the Agencies created OU 3-14 to conduct further investigations and select a final remedy for tank farm soil and groundwater, while interim actions were being implemented under the OU 3-13 ROD. The final remedy for tank farm soil and groundwater in the OU 3-14 ROD supersedes the OU 3-13 Group 1 and Group 5 interim actions. 


\subsubsection{OU 3-13 Group 1, Tank Farm Soil}

2.3.2.1 Tank Farm Interim Action. The Tank Farm Interim Action (TFIA) addressed sites with soil contamination located in the area of the tank farm. The interim action was selected to provide protection until a final remedy could be developed and implemented. The major components of the remedy for the TFIA (Tank Farm Soils, Group 1) (DOE-ID 1999a) were to

- Restrict access to soil to control exposure to workers and prevent exposure to the public

- $\quad$ Reduce precipitation infiltration by $80 \%$ of the average annual precipitation at the tank farm by grading and surface-sealing the tank farm soil

- Use surface water run-on diversion channels to accommodate a one-in-25-year, 24-hour storm event

- Improve exterior building drainage to direct water away from the contaminated areas.

The interim action specified for tank farm soil consisted of institutional controls (ICs) with surface water control to reduce surface water infiltration into tank farm soil until OU 3-14 remedial action begins.

2.3.2.2 Agreement to Resolve Dispute. During implementation of the TFIA Remedial Design/Remedial Action (RD/RA) Work Plan (DOE-ID 2000a), EPA issued a Notice of Violation (NOV) for a dispute raised under the FFA/CO (Kreizenbeck 2002). The NOV alleged that violations were caused by the failure of DOE-ID to complete work as required under the RD/RA Work Plan (DOE-ID 2000a). On February 21, 2003, the Agencies agreed to resolve the dispute.

In the Agreement to Resolve Dispute (ARD) (DOE 2003), DOE-ID agreed to meet the intent of the TFIA by completing two phases. Phase 1, completed before September 30, 2003, included improving storm water drainage and collection to reduce infiltration. Phase 2, completed by September 30, 2004, required DOE-ID to place infiltration barriers over the affected areas of three principal soil contamination sites (CPP-28, CPP-31, and CPP-79). The purpose of Phase 2 was to meet the intent of the interim action, which was to reduce precipitation infiltration.

In the ARD, DOE-ID also agreed to revise the data quality objectives as a modification to the existing Operable Unit 3-14 Tank Farm Soil and Groundwater Phase I Remedial Investigation/Feasibility Study Work Plan (DOE-ID 2000b). The revised RI/FS Work Plan (DOE-ID 2004a) superseded the December 2000 Work Plan and the 1999 RD/RA Scope of Work (DOE-ID 1999b). In the ARD, the Agencies agreed to a planned date of December 31, 2006, for completion of an early draft OU 3-14 ROD.

2.3.2.3 Explanation of Significant Differences for OU 3-13 ROD. DOE-ID also agreed in the ARD to separate the non-tank-farm soil components from the OU 3-14 RI/FS (the former INTEC injection well [CPP-23] and three no action sites [CPP-61, CPP-81, and CPP-82]) and prepare an Explanation of Significant Differences (ESD) to the OU 3-13 ROD to address these components. Additional investigations were completed on the former INTEC injection well and three no action sites (CPP-61, CPP-81, and CPP-82). The investigations determined that the three soil sites required either no action or no further action. The ESD, which was signed by the Agencies in 2004 (DOE-ID 2004b), transferred the three soil sites back to OU 3-13 and finalized the no (further) action decisions for these sites. The investigations also determined that the former injection well was not a continuing source of contamination to groundwater. The ESD transferred the injection well to OU 3-13 Group 5, established additional SRPA monitoring requirements, and modified the Group 5 interim remedy. 


\subsubsection{OU 3-13 Group 2, Soils under Buildings and Structures}

Group 2 release sites are contaminated soils that are located under buildings and structures. Until the buildings and structures are closed and removed, the structures help to minimize infiltration of water through the contaminated soil and prevent direct exposure of personnel. Once the structures are removed, the sites will be remediated in accordance with the remedy that applies to the particular area.

\subsubsection{OU 3-13 Group 3, Other Surface Soils}

Group 3 is other surface soil sites that have been contaminated by radiological and chemical spills and releases. The remediation of Group 3 sites consists of excavation to remove the contaminated soil or capping the contaminated areas. Some Group 3 sites occur in the OU 3-14 industrial use area.

\subsubsection{OU 3-13 Group 4, Perched Water Final Action}

Perched water (limited zone of subsurface water that is separated from the SRPA by layers of unsaturated basalt and other geologic materials) exists beneath the tank farm and is a potential pathway for contaminants to migrate to the aquifer (DOE-ID 1999a). The OU 3-13 perched water (Group 4) remediation goals are to (1) reduce recharge to the perched zones and (2) minimize the migration of contaminants to the aquifer so that SRPA groundwater outside of the INTEC security fence meets, by 2095, applicable State of Idaho groundwater standards (same as maximum contaminant levels [MCLs]). The selected OU 3-13 perched water remedy consists of ICs combined with recharge controls and includes the following items:

- Implementing ICs that include limiting access to prevent perched water use and future unauthorized drilling into or through the perched zone.

- $\quad$ Controlling surface water recharge to perched water by upgrading the surface water drainage system on and near the tank farm and implementing infiltration controls. Actions taken to reduce infiltration include removing the former INTEC percolation ponds from service and replacing them with new percolation ponds located 2 miles west of INTEC, minimizing lawn irrigation at INTEC, minimizing steam condensate discharges to ground, and eliminating the Sewage Treatment Plant's infiltration trenches by redirecting the treated wastewater effluent to the new percolation ponds. The TFIA implemented upgrades to surface water drainage systems within the tank farm and immediate area, including construction of a lined storm water retention pond to manage this drainage. The OU 3-13 ROD also stated that additional infiltration controls, if necessary, might include lining the adjacent reach of the Big Lost River (BLR).

- $\quad$ Measuring moisture content and contaminant of concern (COC) concentrations in the perched water to determine if water contents and contaminant fluxes are decreasing as predicted and to verify the vadose zone model.

\subsubsection{OU 3-13 Group 5, Snake River Plain Aquifer Interim Action}

The human health threat posed by the contaminated SRPA is exposure to radionuclides, via ingestion, of a future worker or hypothetical future resident. The Agencies selected an interim action for the SRPA. While the OU 3-13 remedy selection for the contaminated portion of the SRPA groundwater outside the INTEC security fence was final, the final remedy for the contaminated portion of the SRPA inside the INTEC fence was deferred to OU 3-14. As a result of dividing the SRPA groundwater contaminant plume associated with INTEC operations into two zones, the remedial action was classified as an interim action (DOE-ID 1999a). 
The OU 3-13 remediation goals for the SRPA outside of the current INTEC security fence are

- $\quad$ Prevent current on-Site workers and the public from ingesting groundwater that is contaminated above the applicable State of Idaho groundwater standards or risk-based groundwater concentration during the IC period (i.e., until the year 2095)

- $\quad$ Achieve the applicable State of Idaho groundwater standards or risk-based groundwater concentrations in the SRPA contaminant plume south of the INTEC security fence by the year 2095.

The selected OU 3-13 SRPA interim action for contaminated portions of the SRPA, both inside and outside the INTEC security fence, was ICs with monitoring and contingent remediation to meet MCLs outside the INTEC fence by 2095. The WAG 3, Group 5 Monitoring Report/Decision Summary (MRDS) (DOE-ID 2004c) served as the remedial action report for OU 3-13, Group 5 (Snake River Plain Aquifer). Based on the results of the tasks performed, the conclusions of the MRDS report were that the remedy for Group 5 specified in the 1999 ROD is operational and functional. Additionally, the Group 5 MRDS concluded that

- $\quad$ Contrary to previous modeling predictions, the field and laboratory results demonstrated that elevated radionuclide concentrations do not exist within the HI interbed downgradient of INTEC.

- The former INTEC injection well does not appear to constitute a significant continuing source of contaminants to the aquifer.

- $\quad$ As of 2003, tritium (H-3) and iodine-129 (I-129) activities were already below their respective MCLs in all SRPA monitoring wells downgradient of INTEC; therefore, the RAOs for these two constituents have already been met.

- $\quad$ Strontium-90 (Sr-90) levels in the aquifer in 2003 exceed the MCL downgradient of INTEC, but Sr-90 concentrations are slowly declining in nearly all wells as a result of radioactive decay and dilution/dispersion. Trends indicate that Sr-90 activities in groundwater outside the INTEC security fence will decline below the MCL by 2095.

- $\quad$ The Group 5 remedy is anticipated to be successful in achieving the RAOs established for the aquifer by the year 2095, and there was no need to invoke the contingent remedy (groundwater pump and treat). 


\section{COMMUNITY PARTICIPATION}

The Agencies have been actively engaged in dialogue with the community and have strived for early and meaningful community participation during all remedial activities at the ICP. These community participation activities meet the public participation requirements in CERCLA and the National Oil and Hazardous Substances Pollution Contingency Plan (NCP).

In accordance with CERCLA § 113(k)(2)(b)(i-v) (42 USC 9613(k)(2)(b)(i-v)) and § 117 (42 USC 9617), and the NCP (40 CFR 300.430(f)(3)), opportunities for public information and participation in the OU 3-14 RI/FS project were provided between October 1998 and October 2006. The opportunities to obtain information and/or provide input included the OU 3-13 Proposed Plan (DOE-ID 1998) and ROD (DOE-ID 1999a), two open houses, EM Progress newsletters, two fact sheets, the OU 3-14 Proposed Plan (ICP 2006a), briefings and presentations to interested groups, tours, and public meetings.

In October 1998, the Agencies released to the public the OU 3-13 Proposed Plan, which also briefly outlined the approach for the OU 3-14 RI/FS. The OU 3-13 ROD, released in October 1999, gave further details on the planned scope for the OU 3-14 RI/FS. The Agencies released the ESD for OU 3-13, which addressed additional SRPA monitoring requirements, to the public in January 2004 (DOE-ID 2004b).

In August 2000, the Agencies released an OU 3-14 "kickoff" fact sheet to approximately 1,200 citizens on the Environmental Management (EM) mailing list. DOE-ID also released to the public EM Progress newsletters, which discussed the OU 3-14 project.

DOE-ID provided updates on this project to the Citizens Advisory Board from 1998 through 2006. The advisory board is a group of 15 Idaho citizens who make recommendations to DOE-ID regarding environmental management activities at the INL Site. The Citizens Advisory Board holds meetings every 2 months that are open to the public and include opportunities for public comment.

In March 2006, DOE-ID, EPA, DEQ, INL Oversight Program, and ICP program managers sponsored two open houses to discuss all significant ICP projects, including OU 3-14. The Agencies held one of these evening open houses in Twin Falls during the Citizens Advisory Board's 2-day meeting there. At the conclusion of the RI/FS in late spring 2006, DOE-ID provided specific presentations to the Citizens Advisory Board on (1) the results of the RI and baseline risk assessment (BRA) (May meeting) and (2) the results of the FS and evaluation of remedial alternatives (July meeting).

In July 2006, DOE-ID released a fact sheet to approximately 1,200 citizens on the EM mailing list. The fact sheet discussed the results of the RI/FS and outlined upcoming public involvement opportunities, including briefings, the release of the Proposed Plan, and public meetings.

The OU 3-14 Proposed Plan was mailed to approximately 1,200 citizens on the EM mailing list during the week of August 14, 2006. An electronic copy of the Proposed Plan was made available via the Internet on the ICP home page (http://www.idahocleanupproject.com/). The public comment period for the Proposed Plan began August 22, 2006, and was planned to end on September 21, 2006. However, at the request of the public, DOE-ID extended the comment period 30 days, to October 21, 2006.

Also during the week of August 14, 2006, large display advertisements announcing the availability of the Proposed Plan and the locations of public meetings appeared in regional newspapers in Idaho and one in Wyoming. These ads appeared in the following newspapers: (1) the Post Register (Idaho Falls), (2) the Arco Advertiser (Arco), (3) The Sho-Ban News (Fort Hall), (4) The Idaho State Journal 
(Pocatello), (5) The Times-News (Twin Falls), (6) the Idaho Statesman (Boise), (7) the Moscow-Pullman Daily News (Moscow), and (8) the Jackson Hole News and Guide (Jackson, Wyoming).

Postcards were mailed to approximately 1,200 citizens on the EM mailing list during this time, informing them of the availability of the OU 3-14 Proposed Plan, the duration of the comment period, and the times and locations of upcoming public meetings. An electronic note was sent to all ICP/INL employees providing this information.

On August 17, 2006, a press release was sent to the media, interested Idaho and Wyoming stakeholders, and elected officials concerning the beginning of a 30-day public comment period pertaining to the OU 3-14 Proposed Plan and upcoming public meetings. The news release resulted in articles running in various newspapers and in one publication based in Washington, D.C. The news release gave notice to the public that supportive OU 3-14 investigation documentation was available in the Administrative Record section of the INL Information Repositories located in the INL Technical Library in Idaho Falls and Albertsons Library on the campus of Boise State University as well as on the Internet.

ICP issued another press release on August 25, 2006, to inform the public of the comment period extension for the Proposed Plan, based on a request from the public. A follow-up advertisement ran in newspapers. Additionally, a postcard was mailed to approximately 1,200 citizens on the EM mailing list.

Several telephone calls were made to environmental interest groups in Idaho and Wyoming to remind them of public meetings and the comment period and to assess if a technical briefing was desired. Emails were also sent to these groups and to some elected officials in and near communities where the public meetings were held. DOE-ID, EPA, DEQ, and ICP contractor staff hosted a public meeting in Idaho Falls on August 29, 2006. Approximately 17 people not associated with the OU 3-14 project attended the public meeting. Written comment forms (including a postage-paid, business-reply form) were made available to those attending the public meeting. The forms were used to submit written comments either at the meeting or by mail. A survey form was made available for public use in evaluating the effectiveness of the meeting. A court reporter was also present to record public comments. One person made oral comments and another submitted written comments, which were transcribed by the court reporter. Another public meeting was held in Twin Falls on August 30, 2006. Seven members of the public attended; one provided oral comments. The format was identical to the Idaho Falls public meeting.

The ICP arranged and participated in 12 briefings with environmental interest groups, elected officials, members of the Citizens Advisory Board, and the Shoshone-Bannock Tribes. The OU 3-14 project was also discussed in three separate public tours.

On September 19, 2006, the Citizens Advisory Board met to finalize their formal recommendations on the Proposed Plan. DOE-ID and ICP contractor staff were on hand to answer questions.

The Agencies received both oral and written comments during the comment period. All comments received on the OU 3-14 Proposed Plan were considered during the development of this ROD.

Part 3 of this ROD, the Responsiveness Summary, includes responses to all formal comments presented at the public meetings in Idaho Falls and Twin Falls and all written comments received on the OU 3-14 Proposed Plan during the public comment period. The oral and written comments are also included in the Administrative Record for OU 3-14. 


\section{SCOPE AND ROLE OF RESPONSE ACTION}

This section of the ROD describes the scope and role of the remedial actions to be performed under OU 3-14 and how these actions relate to other cleanup projects being performed on the tank farm. The selected remedy presented in this ROD addresses the contaminated soil and groundwater from historical releases. It is supported by other cleanup projects, including actions performed under the OU 3-13 ROD, disposition of the sodium-bearing waste (SBW) and closure of the TFF, and deactivation, decontamination, and decommissioning (DD\&D) of the surrounding infrastructure. Combined, these actions will permanently close and remediate the tank farm in accordance with applicable environmental regulations and DOE orders.

It is anticipated that the TFF will be closed in 2012 (see Section 2.2). Following closure, INTEC cleanup and waste management activities will continue to support the 1995 Settlement Agreement (DOE 1995), whose key objectives are to remove all SNF from Idaho by 2035 and to prepare waste stored at the INL Site for removal from Idaho by the same date. Many of the waste management facilities and infrastructure around the tank farm will remain active until that mission is completed. Some of the key waste management facilities include the buried tanks north of CPP-604 (WM-100, WM-101, WM-102, WL-101, WL-102 and WL-133); several buildings/structures (CPP-604, CPP-605, CPP-659, CPP-756, and the main stack); and transfer piping and valve boxes located in the tank farm. The active infrastructure to remain past 2012 is shown in purple in Figure 4-1. The OU 3-14 remedy will allow the continued use of this infrastructure while protecting human health and the environment.

The TFF is in an area of established industrial infrastructure. Following closure, this infrastructure will include grouted underground tanks, piping, and ancillary equipment. In addition, the Waste Calcining Facility (WCF) (CPP-633) has been closed with waste left in place to the standards applicable to a HWMA/RCRA landfill. The end state of other nearby facilities, such as the New Waste Calcining Facility (CPP-659), bin sets where calcined waste is stored, and the Fuel Reprocessing Complex (CPP-601, CPP-602, and CPP-630) is unknown at this time, but may include some permanent barriers such as grout. As a result, the Agencies agreed that residential use over these facilities, the associated underground utilities, and the grouted tanks is not a reasonably anticipated future use and that an industrial future land use is appropriate. The outline of the industrial land use area is shown in Figure 4-2.

\subsection{Operable Unit 3-14}

The selected remedy presented in this ROD addresses both the OU 3-14 soil and groundwater contamination from INTEC activities. Action is necessary because workers could be externally exposed to unacceptable levels of cesium-137 (Cs-137) from contamination in the soil. The contaminated soil will be capped to protect workers from exposure to Cs-137. Action is also necessary to restore to MCLs that portion of the SRPA contaminated by INTEC releases and to prevent ingestion of contaminated groundwater at INTEC. If no action is taken, the Sr-90 contamination in the perched water system could migrate to the SRPA and present an unacceptable risk to hypothetical future residents outside of the industrial land use area and to future workers who might drink the groundwater. Infiltration controls will also be implemented at INTEC to reduce the migration of Sr-90 from the perched water system to the SRPA so that MCLs are met beneath INTEC by 2095. 


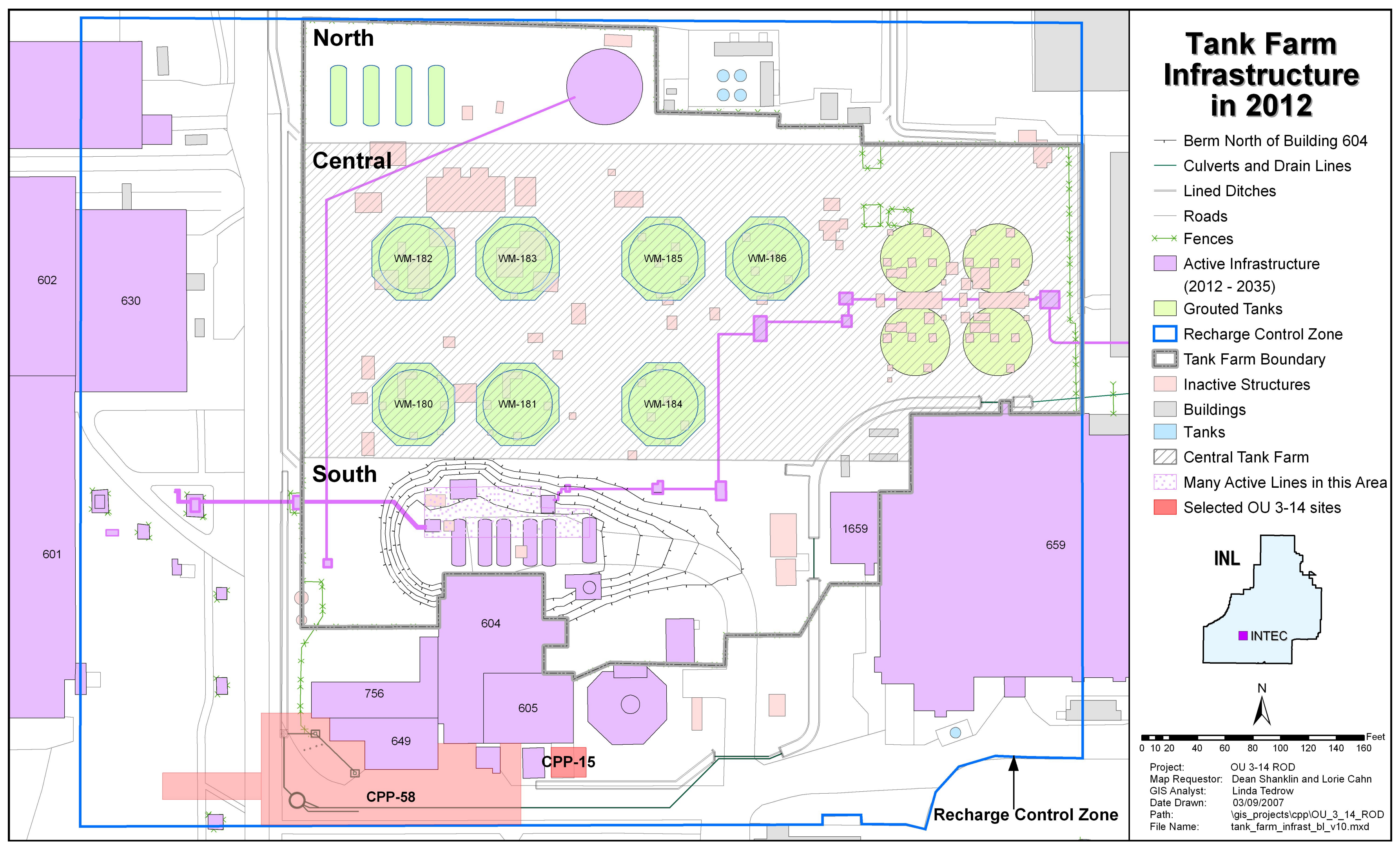

Figure 4-1. Tank farm—north, central, and south sections—-shown with recharge control zone and planned active infrastructure in 2012. 


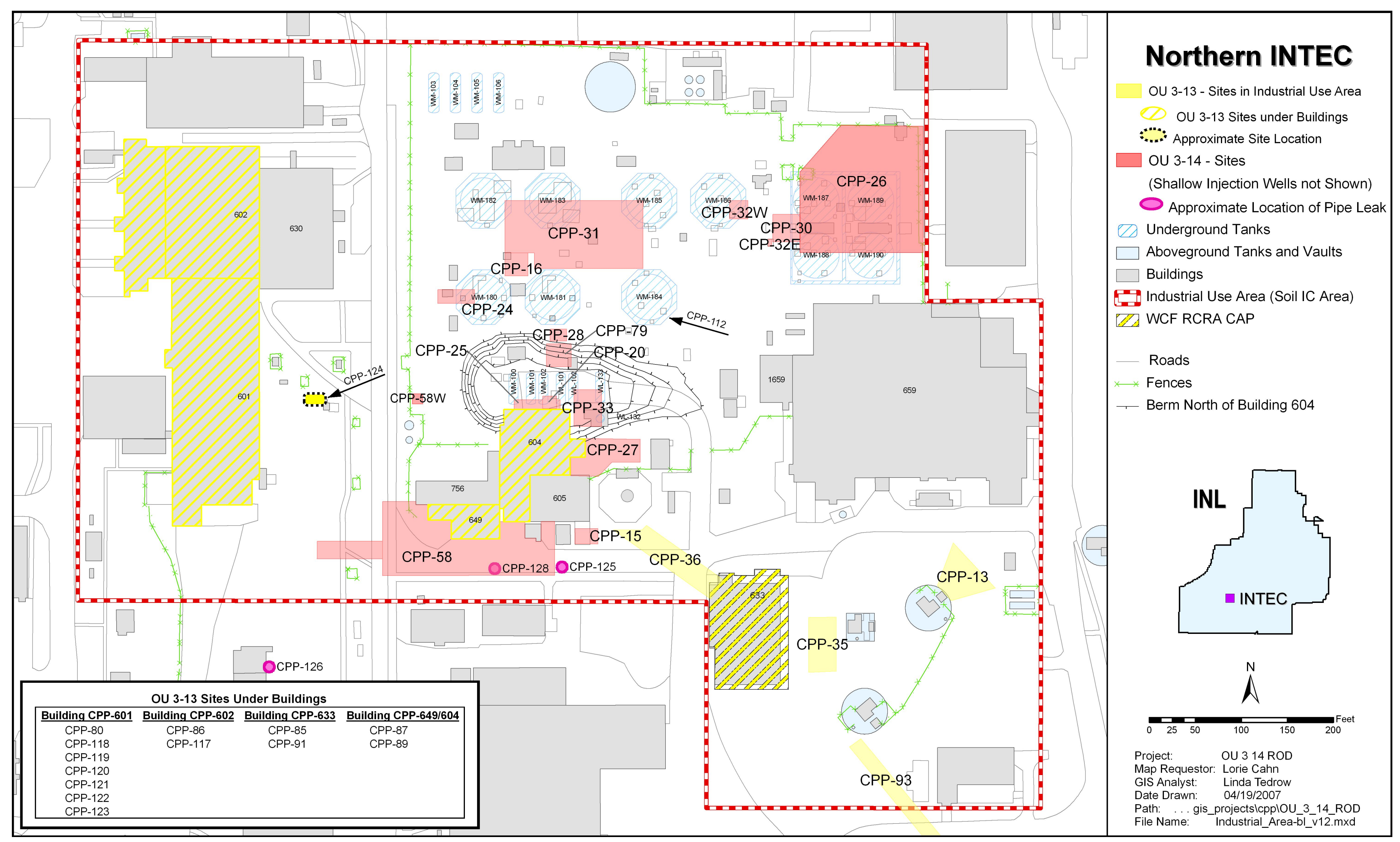

Figure 4-2. Industrial use area (soil institutional control area) and CERCLA sites. 
The principal infiltration control will consist of an infiltration-reducing, low-permeability pavement (or equivalent barrier) that will be installed over the recharge control zone (RCZ), which is centered over the tank farm (see Figure 4-1). This pavement will greatly reduce the amount of water infiltrating from the surface down through the perched water and interbeds. Without this water, the Sr-90 in perched water and interbeds will be less mobilized. Because the pavement is about 6 in. thick, it can be installed around the existing infrastructure without disrupting operations in northern INTEC. It will require ongoing maintenance (such as patching) to ensure its effectiveness and the use of lift stations to remove surface water accumulating in the low areas and to transport that water to a lined evaporation pond.

Other infiltration controls will also be implemented in northern INTEC to reduce the amount of anthropogenic and storm water infiltrating through the northern perched water. Some of these controls include (1) eliminating intentional water discharges (lawn watering, steam condensate, etc.) in northern INTEC; (2) improving the surface water diversion system around the low-permeability pavement; (3) improving the metering of INTEC water usage; and (4) real-time water level monitoring in selected northern perched water wells. These additional controls will continue during the timeframe of active operations in northern INTEC.

Once the active infrastructure in northern INTEC is no longer needed and is demolished, an evapotranspiration cap with a capillary biobarrier (ET/CB) will be installed over approximately two-thirds of the tank farm that correspond to areas having higher soil contamination (e.g., over the soil release sites). This cap varies in thickness and is a minimum of $6 \mathrm{ft}$ thick at the edges of the south and central tank farm and sloped to drain from the crown. It will protect workers from external exposure to contaminated soil, reduce water infiltration, and prevent biota from intruding through the cap and bringing contamination to the surface. This type of cap requires less maintenance than the low-permeability pavement and does not require lift stations or evaporation ponds for managing surface water. Instead, it minimizes recharge by storing moisture and returning it to the air using plants and evaporation.

\subsection{Coordination between Operable Units 3-13 and 3-14}

As described in Section 2.3, the OU 3-13 ROD selected interim actions for the tank farm soil and the SRPA and final actions for the other contaminated soil sites that reside within the industrial land use area and for the perched water. The OU 3-13 ESD (DOE-ID 2004b) transferred the injection well (CPP-23) back to Group 5 and modified the Group 5 remedy. Coordination of the actions under OU 3-13 and OU 3-14 is given below:

- The OU 3-13, Group 1, Tank Farm Interim Action, is currently in operation to reduce the amount of precipitation infiltrating through the contaminated tank farm soil. The primary components of this system (diversion ditches, lift station, evaporation pond, etc.) will be enhanced under the OU 3-14 remedy to help meet the performance requirements for infiltration reduction.

- $\quad$ The OU 3-13, Group 5 interim action (ICs with monitoring and contingent pump and treat, see Section 2.3.6) was selected for the portion of the SRPA contaminated from INTEC activities. This OU 3-13 interim action was modified by the ESD (DOE-ID 2004b), which transferred the injection well to Group 5 and modified the steps that would trigger the OU 3-13 interim action of contingent pump and treat. The ESD required vertical profiling of three SRPA monitoring wells (USGS-44, USGS-46, and USGS-47) to determine if I-129 concentrations exceeded the modified trigger level of $5 \mathrm{pCi} / \mathrm{L}$. An assessment of results of the vertical profiling has shown that I-129 concentrations in the SRPA are below $5 \mathrm{pCi} / \mathrm{L}$ and further vertical profiling was discontinued. The remedy selected in the OU 3-14 ROD supersedes the OU 3-13 interim remedy. However, until the OU 3-14 RD/RA 
work plan and groundwater monitoring plan are developed and implemented, the OU 3-13 Group 5 interim activities of ICs and groundwater monitoring will be continued.

- $\quad$ The OU 3-13, Group 4 final action (ICs with aquifer recharge controls) was selected for the contaminated perched water beneath INTEC (see Section 2.3.5). The OU 3-13 Group 4 remediation goals are to (1) reduce recharge to the perched zones and (2) minimize the migration of contaminants to the SRPA so that SRPA groundwater outside of the current INTEC security fence meets applicable State of Idaho groundwater standards by 2095. Based upon the results of the OU 3-14 groundwater modeling, it is anticipated that no additional actions will be required to meet the OU 3-13 RAOs for perched water. However, OU 3-14 will implement actions to reduce infiltration through contaminated perched water that could contribute to SRPA contamination at INTEC. In addition, monitoring of perched water will continue under Group 4 until it is incorporated into the WAG 3 groundwater monitoring plan included in the OU 3-14 RD/RA work plan.

- The OU 3-13, Group 3 sites within the industrial land use area include three sites east of the WCF cap (CPP-13, CPP-35, and the northern portion of CPP-93); one site between the stack and the WCF cap (CPP-36); one site under the WCF cap (CPP-91); and one site between the tank farm and Building CPP-601 (CPP-124). These sites are shown on Figure 4-2. These sites will be cleaned up under the OU 3-13, Group 3 Phase II Remedial Design/Remedial Action Work Plan (DOE-ID 2006a) using the OU 3-14 remediation goals for soil in the industrial use area.

- $\quad$ The OU 3-13, Group 2 sites within the industrial land use area include sites under Buildings CPP-601 and CPP-602 (CPP-80, CPP-86, CPP-117, CPP-118, CPP-119, CPP-120, CPP-121, CPP-122, and CPP-123) and under Buildings CPP-649 and CPP-604 (CPP-87 and CPP-89). These are shown on Figure 4-2 as hatched areas in yellow. These sites will be cleaned up under OU 3-13 in accordance with the process identified in the Operable Unit 3-13 Group 2 Closure Evaluation Criteria and Checklist (DOE-ID 2000c) using the OU 3-14 remediation goals for soil in the industrial use area.

\subsection{Deactivation, Decontamination, and Decommissioning}

Many buildings and structures located in and around the OU 3-14 sites require closure prior to completing the OU 3-13 and OU 3-14 remedies. For example, the low-permeability pavement cannot be installed over the tank farm until several structures have been removed. The ET/CB cap cannot be installed in the southern portion of the tank farm until the affected facilities (CPP-604, CPP-605, etc.) and structures (Tanks WM-100, WM-101, WM-102, WL-101, WL-102, and WL-133) are no longer in use. Finally, the OU 3-13 Group 2 sites cannot be remediated until the overlying facilities have been closed. Once these infrastructure are no longer needed for ongoing cleanup activities, they may need DD\&D before they can be demolished. Some of these actions are being conducted under DOE's CERCLA removal authority as non-time-critical removal actions. Contaminated waste and debris from these removal actions are being disposed of in the Idaho CERCLA Disposal Facility (ICDF) located outside the southwestern corner of INTEC. For example, Building CPP-627 (Remote Analytical Facility), located just west of the TFF, has undergone DD\&D as a non-time-critical removal action (ICP 2006b) and the building has been demolished. The sequencing of the OU 3-14 remedy has been integrated with the OU 3-13 remedy, INTEC operations, TFF closure, and facility DD\&D. 


\section{SITE CHARACTERISTICS}

This section discusses the types of waste at the tank farm and describes the known releases and soil contamination. It then discusses site characteristics - geology, surface water sources, hydrogeology — and current aquifer and perched water contamination as well as the source term used in modeling to describe the releases to the environment. The conceptual model is then presented, followed by a summary of the groundwater modeling, which predicts transport of contamination in the subsurface in the future.

\subsection{Types of OU 3-14 Waste}

Two types of waste contributed to OU 3-14 contamination - tank farm waste and waste sent to the former injection well. The waste managed at the INTEC tank farm came from reprocessing SNF and related activities such as equipment decontamination, uranium purification, laboratory work, off-gas treatment, fuel receipt and storage, and waste calcination. There were five major sources of tank farm waste: first-cycle, second-cycle, and third-cycle raffinates from SNF reprocessing; process equipment waste (PEW) evaporator concentrate; and miscellaneous sources.

Reprocessing SNF generated the greatest volume of waste. Typically, SNF reprocessing had three steps. Each reprocessing step generated liquid waste, called raffinate. The first step (called first-cycle extraction) separated the uranium from the dissolved fuel cladding and radioactive material in the SNF and generated first-cycle raffinate. First-cycle raffinate is classified as high-level waste (HLW). The second and third SNF reprocessing steps (called second- and third-cycle extraction) purified the uranium in preparation for off-Site shipment and generated second- and third-cycle raffinates. First-cycle raffinate comprised the bulk of the SNF reprocessing waste in terms of both radiological activity and waste volume.

The PEW evaporator system collected dilute radioactive wastes from a variety of sources, including equipment decontamination, cell floors drainage, fuel storage basin water treatment systems, laboratories, off-gas condensers, and other SNF support activities. The evaporator concentrated the dilute waste and sent the concentrate (bottoms) to the tank farm, where it was often combined with the SNF second- and third-cycle raffinates for storage. This waste became known as SBW due to its high concentrations of sodium and potassium nitrates (1-2 molar). SBW is an acidic waste that contains much less radioactivity than first-cycle raffinate (typically 10 to 100 times less).

The tank farm wastes also included "miscellaneous" wastes such as steam-jet condensate, dilute wastes that exceeded the Waste Acceptance Criteria for the PEW evaporator, and nonradioactive waste from equipment testing and operator training.

The vapors from the PEW evaporator, which contained traces of radioactivity, were condensed, sampled, and discharged to the former INTEC injection well (until the mid-1980s) via the service waste system.

\subsection{OU 3-14 Soil Sites}

Operable Unit 3-14 consists of sites that required additional information when the OU 3-13 ROD was signed or are newly identified sites. For the sites that were known when the OU 3-13 ROD was signed, the OU 3-13 ROD selected an interim action and deferred the final remedy to OU 3-14. Table 5-1 lists all CERCLA soil sites at INTEC that are part of OU 3-14. Some of these sites were transferred to OU 3-14 by the OU 3-13 ROD, and some were newly identified sites that the Agencies agreed should be part of OU 3-14. 
Table 5-1. OU 3-14 soil sites.

\begin{tabular}{|c|c|c|c|}
\hline $\begin{array}{c}\text { Site } \\
\text { Name }\end{array}$ & Site Description & $\begin{array}{l}\text { Pathway } \\
\text { to OU 3-14 }\end{array}$ & \begin{tabular}{|l} 
Final Disposition \\
in OU 3-14
\end{tabular} \\
\hline CPP-15 & $\begin{array}{l}\text { Spill from storage tank associated with solvent burner east of } \\
\text { CPP-605 }\end{array}$ & OU 3-13 ROD & $\mathrm{RD} / \mathrm{RA}$ \\
\hline CPP-16 & $\begin{array}{l}\text { Contaminated soil from leak in line from Tank WM-181 to } \\
\text { PEW evaporator }\end{array}$ & OU 3-13 ROD & $\mathrm{RD} / \mathrm{RA}$ \\
\hline CPP-20 & CPP-604 radioactive waste unloading area & OU 3-13 ROD & $\mathrm{RD} / \mathrm{RA}$ \\
\hline CPP-24 & Tank farm area bucket spill & OU 3-13 ROD & $\mathrm{RD} / \mathrm{RA}$ \\
\hline CPP-25 & Contaminated soil in the tank farm area north of CPP-604 & OU 3-13 ROD & $\mathrm{RD} / \mathrm{RA}$ \\
\hline CPP-26 & Contaminated soil in the tank farm area from steam flushing & OU 3-13 ROD & $\mathrm{RD} / \mathrm{RA}$ \\
\hline CPP-27 & Contaminated soil in the tank farm area east of CPP-604 & OU 3-13 ROD & $\mathrm{RD} / \mathrm{RA}$ \\
\hline СРP-28 & $\begin{array}{l}\text { Contaminated soil in the tank farm area south of Tank WM-181 } \\
\text { by Valve Box A-6 }\end{array}$ & OU 3-13 ROD & $\mathrm{RD} / \mathrm{RA}$ \\
\hline CPP-30 & Contaminated soil in the tank farm area near Valve Box B-9 & OU 3-13 ROD & $\mathrm{RD} / \mathrm{RA}$ \\
\hline CPP-31 & Contaminated soil in the tank farm area south of Tank WM- 183 & OU 3-13 ROD & $\mathrm{RD} / \mathrm{RA}$ \\
\hline CPP-32 & $\begin{array}{l}\text { Contaminated soil in the tank farm area southwest and } \\
\text { northwest of Valve Box B-4 }\end{array}$ & OU 3-13 ROD & $\mathrm{RD} / \mathrm{RA}$ \\
\hline CPP-33 & $\begin{array}{l}\text { Contaminated soil in the tank farm area near Tank WL-102, } \\
\text { northeast of CPP-604 }\end{array}$ & OU 3-13 ROD & $\mathrm{RD} / \mathrm{RA}$ \\
\hline CPP-58 & $\begin{array}{l}\text { Pipeline spills of PEW evaporator overheads outside the tank } \\
\text { farm boundary near the southwest corner }\end{array}$ & OU 3-13 ROD & $\mathrm{RD} / \mathrm{RA}$ \\
\hline CPP-58W & $\begin{array}{l}1954 \text { service waste line leak inside tank farm boundary between } \\
\text { CPP-601 and CPP-604 }\end{array}$ & OU 3-13 ROD & $\mathrm{RD} / \mathrm{RA}$ \\
\hline CPP-79 & Tank farm releases near Valve Box A-2 (shallow/deep) & OU 3-13 ROD & $\mathrm{RD} / \mathrm{RA}$ \\
\hline СРP-96 & $\begin{array}{l}\text { All soil sites transferred to OU } 3-14 \text { in the OU } 3-13 \text { ROD and } \\
\text { interstitial soil inside the tank farm boundary, including } \\
\text { contaminated backfill }\end{array}$ & OU 3-13 ROD & $\mathrm{RD} / \mathrm{RA}$ \\
\hline CPP-102 & Shallow injection well from steam system & New site & No action \\
\hline CPP-103 & Shallow injection well from steam system & New site & No action \\
\hline CPP-104 & Shallow injection well associated with fuel oil storage tanks & New site & No action \\
\hline CPP-105 & Shallow injection well associated with fuel oil storage tanks & New site & No action \\
\hline CPP-106 & Shallow injection well associated with fuel oil storage tanks & New site & No action \\
\hline CPP-107 & Shallow injection well associated with fuel oil storage tanks & New site & No action \\
\hline CPP-108 & Shallow injection well associated with fuel oil storage tanks & New site & No action \\
\hline CPP-109 & Shallow injection well from steam system & New site & No action \\
\hline CPP-110 & Shallow injection well from steam system & New site & No action \\
\hline CPP-112 & $\begin{array}{l}\text { Potential release from tank vault around Tank WM-184 during } \\
\text { rinsing with deionized water }\end{array}$ & New site & $\mathrm{RD} / \mathrm{RA}$ \\
\hline CPP-113 & Shallow injection well from steam system & New site & No action \\
\hline
\end{tabular}


Table 5-1. (continued).

\begin{tabular}{|c|l|l|l|}
\hline $\begin{array}{c}\text { Site } \\
\text { Name }\end{array}$ & \multicolumn{1}{|c|}{ Site Description } & \multicolumn{1}{|c|}{$\begin{array}{c}\text { Pathway } \\
\text { to OU 3-14 }\end{array}$} & $\begin{array}{l}\text { Final Disposition } \\
\text { in OU 3-14 }\end{array}$ \\
\hline CPP-114 & Shallow injection well from steam system & New site & No action \\
\hline CPP-115 & Shallow injection well from steam system & New site & No action \\
\hline CPP-116 & Shallow injection well from steam system & New site & No action \\
\hline CPP-125 & 1 1/2" SWA-106450 leak north of CPP-1618 & New site & No action \\
\hline CPP-126 & 20" SW-NS-110477 flange leak east of CPP-601 & New site & No action \\
\hline CPP-128 & 4" SWA-100532 leak near the intersection with 8" SWN-3001 & New site & No action \\
\hline
\end{tabular}

Sites CPP-15, CPP-16, CPP-20, CPP-24, CPP-25, CPP-26, CPP-27, CPP-28, CPP-30, CPP-31, CPP-32, CPP-33, CPP-58, CPP-58W, and CPP-79 were transferred by the OU 3-13 ROD to OU 3-14. They were combined with contaminated backfill in the tank farm and became CPP-96. All of these OU 3-14 sites are inside the tank farm boundary except for CPP-15 and CPP-58. Three of these sites (CPP-16, CPP-20, and CPP-30) were no action sites in OU 3-13 but were reinvestigated under OU 3-14 and are part of the soil inside the tank farm boundary selected for remediation in this OU 3-14 ROD.

Sites CPP-102 through CPP-110 and CPP-113 through CPP-116 are shallow injection wells that were identified as new sites for OU 3-14 after the OU 3-13 ROD was signed and are no action sites under CERCLA. Sites CPP-125, CPP-126, and CPP-128 are new sites in OU 3-14 that are outside the tank farm boundary and are no action sites (ICP 2005a, b, c). CPP-112 is a new site under OU 3-14 that is inside the tank farm and will be discussed as part of the remedy for soil inside the tank farm boundary (ICP 2005d).

\subsubsection{Soil Sampling Strategy}

The contaminated soil sites at the tank farm were investigated through various sampling and probing activities between the initial discovery of each site and the OU 3-13 investigation in 1995 (DOE-ID 1997a, b). As part of the OU 3-13 ROD, the Agencies determined that they needed more information on these sites before they could make a final remedial action decision. The sampling strategy for OU 3-14, discussed in detail in the OU 3-14 RI/FS Work Plan (DOE-ID 2004a), addressed these key data needs:

- Determine the extent, distribution, and composition of contamination at known release sites

- $\quad$ Characterize soil from known release sites between the ground surface and basalt as necessary to support RI/FS tasks

- $\quad$ Estimate the level of contamination in the tank farm soil used for backfill.

The Agencies determined that additional information was needed to address these data gaps for Sites CPP-15, CPP-27, CPP-28, CPP-31, and CPP-79. New probeholes were installed and downhole gamma radiation surveys conducted on all new and existing probeholes. Samples were collected in selected probeholes every $4 \mathrm{ft}$ through the alluvium for laboratory analysis. The locations of all probeholes and sampling locations are shown on Figure 5-1, and the analyses run by the laboratory are listed in Table 5-2. Section 5 of the OU 3-14 RI/BRA (DOE-NE-ID 2006a) contains details on the 2004 field investigation, including analytical methods, quality assurance/quality control requirements, and sampling results. 


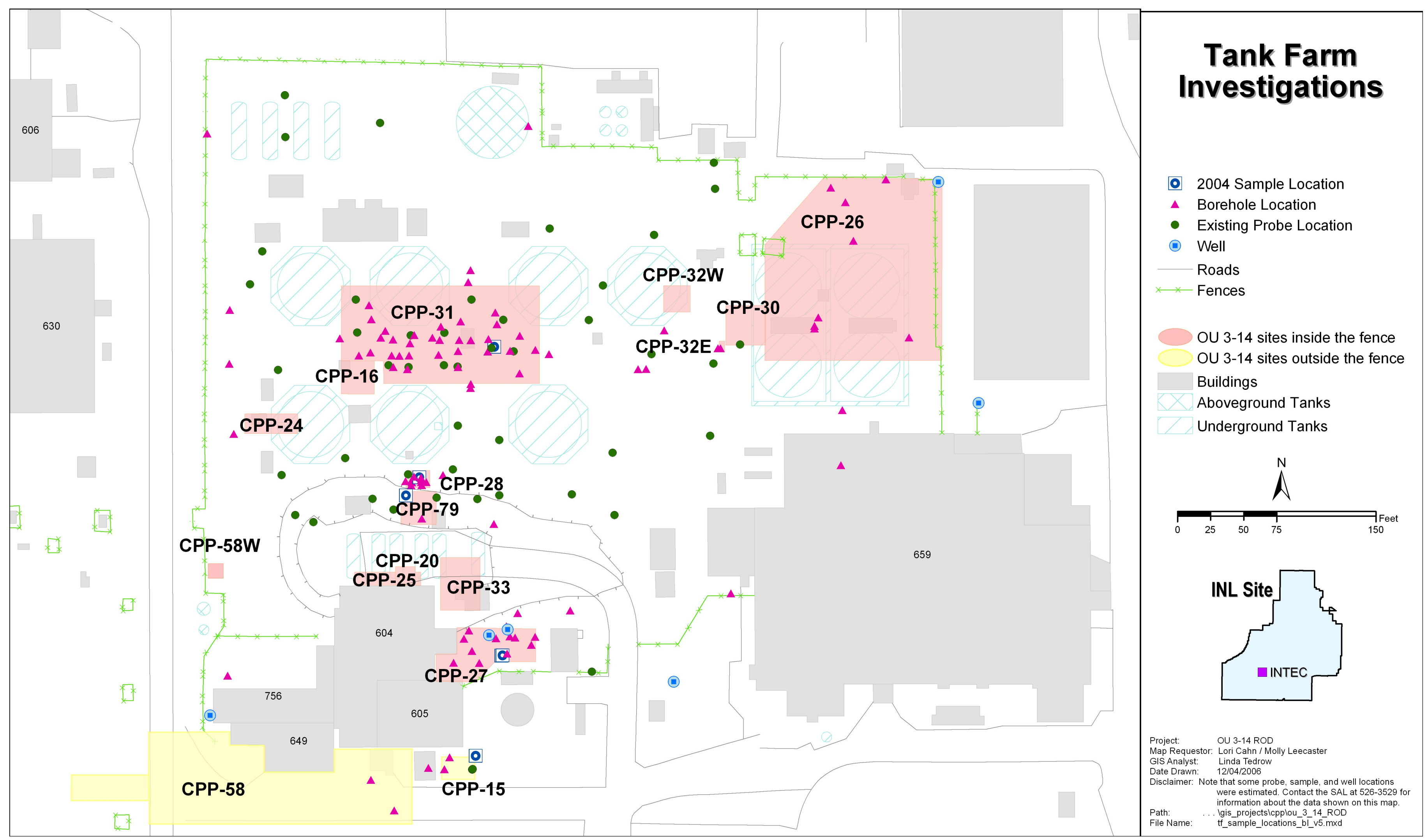

Figure 5-1. OU 3-14 probeholes and sampling locations. 
Table 5-2. Laboratory analyses of samples during the 2004 OU 3-14 field investigation.

\begin{tabular}{ll}
\hline Analytical Group & Analytes \\
\hline Radionuclides & $\mathrm{H}-3, \mathrm{C}-14, \mathrm{Sr}-90, \mathrm{Tc}-99, \mathrm{I}-129, \mathrm{Cs}-137, \mathrm{Eu}-154, \mathrm{U}-235, \mathrm{U}-238$, \\
& $\mathrm{Np}-237, \mathrm{Pu}-238, \mathrm{Pu}-239 / 240, \mathrm{Am}-241$ \\
Metals & Arsenic, chromium, mercury \\
Wet chemistry & Nitrate-N, nitrite-N, pH \\
Organic compounds & Appendix IX to 40 CFR 264 target analyte list semivolatile organic \\
& compounds and volatile organic compounds \\
Toxicity characteristic leaching procedure & Metals and organic compounds \\
\hline
\end{tabular}

\subsubsection{OU 3-14 2004 Soil Sampling Results}

The sample results for COCs are shown on Table 5-3. Site CPP-31 contained the highest activities for Cs-137 (8,990,000 pCi/g at 18-20 ft bgs [below ground surface]) and for Sr-90 (20,700,000 pCi/g at $22-24 \mathrm{ft} \mathrm{bgs})$. Site CPP-79 contained the highest concentration of nitrate ( $9 \mathrm{mg} / \mathrm{kg}$ at $44-46 \mathrm{ft} \mathrm{bgs})$. I-129 was not detected.

Table 5-3. Fiscal Year 2004 soil sampling summary for contaminants of concern. ${ }^{\mathrm{a}}$

\begin{tabular}{|c|c|c|c|c|c|c|}
\hline & $\begin{array}{l}\text { Depth } \\
\text { (ft) }\end{array}$ & $\begin{array}{l}\text { Cs-137 } \\
(\mathrm{pCi} / \mathrm{g})\end{array}$ & $\begin{array}{c}\mathrm{Sr}-90 \\
(\mathrm{pCi} / \mathrm{g})\end{array}$ & $\begin{array}{c}\mathrm{I}-129 \\
(\mathrm{pCi} / \mathrm{g})\end{array}$ & $\begin{array}{c}\text { Tc-99 } \\
(\mathrm{pCi} / \mathrm{g})\end{array}$ & $\begin{array}{c}\text { Nitrate-N } \\
(\mathrm{mg} / \mathrm{kg})\end{array}$ \\
\hline CPP-15 & $1.4-2.8$ & 59 & $27 \mathrm{~J}$ & $\mathrm{U}$ & UJ & 4 \\
\hline \multirow[t]{4}{*}{ (slant) } & $4.2-5.7$ & 90 & $12 \mathrm{~J}$ & $\mathrm{U}$ & 4 & 3 \\
\hline & $7.1-8.5$ & 85 & $21 \mathrm{~J}$ & $\mathrm{U}$ & 11 & 4 \\
\hline & $9.9-11.3$ & 47,000 & $7,180 \mathrm{~J}$ & $\mathrm{U}$ & 15 & 4 \\
\hline & $11.3-12.7$ & 5,830 & $13,900 \mathrm{~J}$ & $\mathrm{U}$ & 26 & 3 \\
\hline \multirow[t]{9}{*}{ CPP-27 } & $2-4$ & $\mathrm{U}$ & $\mathrm{U}$ & $\mathrm{U}$ & UJ & 3 \\
\hline & $6-8$ & 40 & $126 \mathrm{~J}$ & $\mathrm{U}$ & $\mathrm{U}$ & 3 \\
\hline & $10-12$ & 25 & $8 \mathrm{~J}$ & $\mathrm{U}$ & $\mathrm{U}$ & 4 \\
\hline & $14-16$ & 288 & $711 \mathrm{~J}$ & $\mathrm{U}$ & UJ & 3 \\
\hline & $18-20$ & 7 & $24 \mathrm{~J}$ & $\mathrm{U}$ & 4 & 3 \\
\hline & $20-24$ & U & U & $\mathrm{U}$ & 7 & 3 \\
\hline & $24-28$ & U & UJ & $\mathrm{U}$ & 3 & 2 \\
\hline & $28-32$ & UJ & U & $\mathrm{U}$ & U & 3 \\
\hline & $32-36$ & UJ & $\mathrm{U}$ & $\mathrm{U}$ & $\mathrm{U}$ & 2 \\
\hline \multirow[t]{10}{*}{ СРP-28 } & $2-3$ & 1,070 & $78 \mathrm{~J}$ & $\mathrm{U}$ & UJ & 4 \\
\hline & $6-7$ & 217 & $34 \mathrm{~J}$ & $\mathrm{U}$ & 3 & 2 \\
\hline & $8-12$ & 1,180 & 32,600 & $\mathrm{U}$ & 16 & 1 \\
\hline & $12-16$ & 1 & 21,600 & $\mathrm{U}$ & 100 & 1 \\
\hline & $16-20$ & 3 & 3,040 & $\mathrm{U}$ & $4 \mathrm{~J}$ & $\mathrm{U}$ \\
\hline & $20-24$ & 0.5 & 3,950 & $\mathrm{U}$ & $4 \mathrm{~J}$ & 1 \\
\hline & $\begin{array}{l}20-24 \\
\text { duplicate }\end{array}$ & 0.5 & 2,460 & $\mathrm{U}$ & $3 \mathrm{~J}$ & 1 \\
\hline & $24-28$ & 3 & 56 & $\mathrm{U}$ & $3 \mathrm{~J}$ & 1 \\
\hline & $28-32$ & $2,540,000$ & 223,000 & $\mathrm{U}$ & $196 \mathrm{~J}$ & 1 \\
\hline & $32-36$ & 110 & 379,000 & U & $40 \mathrm{~J}$ & 1 \\
\hline
\end{tabular}


Table 5-3. (continued).

\begin{tabular}{|c|c|c|c|c|c|c|}
\hline & $\begin{array}{l}\text { Depth } \\
\text { (ft) }\end{array}$ & $\begin{array}{l}\text { Cs-137 } \\
(\mathrm{pCi} / \mathrm{g})\end{array}$ & $\begin{array}{c}\mathrm{Sr}-90 \\
(\mathrm{pCi} / \mathrm{g})\end{array}$ & $\begin{array}{c}\mathrm{I}-129 \\
(\mathrm{pCi} / \mathrm{g})\end{array}$ & $\begin{array}{c}\mathrm{Tc}-99 \\
\text { (pCi/g) }\end{array}$ & $\begin{array}{c}\text { Nitrate-N } \\
(\mathrm{mg} / \mathrm{kg})\end{array}$ \\
\hline \multirow[t]{5}{*}{$\begin{array}{l}\text { CPP-28 } \\
\text { (con't.) }\end{array}$} & $36-40$ & 1 & 1,950 & $\mathrm{U}$ & $3 \mathrm{~J}$ & $\mathrm{U}$ \\
\hline & $40-44$ & 1 & 95 & UJ & $7 \mathrm{~J}$ & $\mathrm{U}$ \\
\hline & $44-48$ & 4 & 19 & $\mathrm{U}$ & $5 \mathrm{~J}$ & 1 \\
\hline & $48-52$ & 2 & 18,000 & $\mathrm{U}$ & $2 \mathrm{~J}$ & 1 \\
\hline & $52-56$ & 1 & 85,200 & $\mathrm{U}$ & $3 \mathrm{~J}$ & 1 \\
\hline \multirow[t]{12}{*}{ СРP-31 } & $0-4$ & 214 & $\mathrm{U}$ & $\mathrm{U}$ & $\mathrm{U}$ & $0.033 \mathrm{~J}$ \\
\hline & $6-8$ & 438 & 175 & $\mathrm{U}$ & $\mathrm{U}$ & 0.065 \\
\hline & $10-12$ & 428 & 815 & UJ & $\mathrm{U}$ & 0.162 \\
\hline & $14-16$ & 241,000 & 547,000 & $\mathrm{U}$ & 13 & 0.099 \\
\hline & $16-18$ & $3,720,000$ & $1,320,000^{\mathrm{b}}$ & NA & NA & NA \\
\hline & $18-20$ & $8,990,000$ & $1,850,000$ & $\mathrm{U}$ & 69 & $0.054 \mathrm{~J}$ \\
\hline & $22-24$ & 57,500 & $20,700,000$ & $\mathrm{U}$ & 23 & $0.038 \mathrm{~J}$ \\
\hline & $26-28$ & 63 & 810,000 & $\mathrm{U}$ & 25 & 0.072 \\
\hline & $30-32$ & 126 & 663,000 & $\mathrm{U}$ & 17 & $0.049 \mathrm{~J}$ \\
\hline & $32-36$ & 73 & 941,000 & UJ & 16 & 0.089 \\
\hline & $36-40$ & 33 & 528,000 & $\mathrm{U}$ & 7 & 0.097 \\
\hline & $\begin{array}{l}36-40 \\
\text { duplicate }\end{array}$ & 32 & 603,000 & $\mathrm{U}$ & 65 & 0.111 \\
\hline \multirow[t]{16}{*}{ CРP-79 } & $2-4$ & 30 & 20 & UJ & $3 \mathrm{~J}$ & 1 \\
\hline & $6-8$ & 53 & 48 & $\mathrm{U}$ & $2 \mathrm{~J}$ & 1 \\
\hline & $10-12$ & 78 & 76 & $\mathrm{U}$ & $\mathrm{U}$ & 1 \\
\hline & $14-16$ & 110 & 38 & $\mathrm{U}$ & $1 \mathrm{~J}$ & 1 \\
\hline & $16-18$ & 19,600 & 25,900 & $\mathrm{U}$ & 33 & 3 \\
\hline & $20-22$ & 0.2 & 29,200 & $\mathrm{U}$ & UJ & 3 \\
\hline & $24-26$ & UJ & 13,400 & $\mathrm{U}$ & 65 & 1 \\
\hline & $30-32$ & $0.02 \mathrm{~J}$ & 9J & $\mathrm{U}$ & 19 & 1 \\
\hline & $34-36$ & $3,350,000$ & 219,000 & $\mathrm{U}$ & 182 & 1 \\
\hline & $36-38$ & 1,770 & 60,100 & $\mathrm{U}$ & 15 & $0.2 \mathrm{~J}$ \\
\hline & $42-44$ & 455 & 6 & $\mathrm{U}$ & $4 \mathrm{~J}$ & 4 \\
\hline & $44-46$ & 300 & 10 & $\mathrm{U}$ & $2 \mathrm{~J}$ & 9 \\
\hline & $\begin{array}{l}44-46 \\
\text { duplicate }\end{array}$ & 301 & 8 & UJ & $3 \mathrm{~J}$ & 8 \\
\hline & $48-52$ & 293 & 126 & $\mathrm{U}$ & $3 \mathrm{~J}$ & 7 \\
\hline & $52-56$ & 31 & 25 & $\mathrm{U}$ & $2 \mathrm{~J}$ & 5 \\
\hline & $56-60$ & $1,350,000$ & 34,700 & UJ & $13 \mathrm{~J}$ & 6 \\
\hline \multicolumn{7}{|c|}{$\begin{array}{l}\text { a. U means not detected; UJ means false positive; J means estimated quantity. NA means not analyzed; standard error not shown but can be } \\
\text { found in Appendix G of DOE-NE-ID ( } 2006 \mathrm{a}) \text {. } \\
\text { b. Total strontium, which is equivalent to Sr-90 for this sample. }\end{array}$} \\
\hline
\end{tabular}




\subsubsection{Soil Site Descriptions}

The following sections provide a brief summary of each OU 3-14 soil site. CPP-96 sites will be discussed first, followed by the no action sites. All the individual OU 3-14 soil sites are shown in Figure 4-2 except the shallow injection wells, which will be discussed in Section 5.2.3.19. The results of field investigations, analytical data, employee interviews, historical record searches, and process knowledge have been used to determine the nature and extent of contamination and establish the source terms (volume and composition of liquid released) at the OU 3-14 sites. Extensive details on the releases, previous sampling and cleanup, and nature and extent of contamination remaining can be found in Section 5 of the RI/BRA (DOE-NE-ID 2006a).

5.2.3.1 CPP-96. CPP-96 includes all soil inside the tank farm boundary, including contaminated backfill (Sites CPP-16, CPP-20, CPP-24, CPP-25, CPP-26, CPP-27, CPP-28, CPP-30, CPP-31, CPP-32, CPP-33, CPP-58W, CPP-79, and CPP-112) and two soil sites adjacent to the tank farm (CPP-15 and CPP-58). Three of these sites (CPP-16, CPP-20, and CPP-30) were no action sites in OU 3-13 but were reinvestigated under OU 3-14 and are to be remediated under this OU 3-14 ROD.

All soil inside the tank farm boundary is included in Site CPP-96 because major tank farm construction and maintenance projects spread contamination from the CERCLA release sites to other areas of the tank farm when contaminated soil was placed back in excavations as backfill. The backfill met requirements for use as backfill in the tank farm at the time, but does not meet the more stringent cleanup criteria under CERCLA. Sampling data collected in 2004, historical records, and photos support this conclusion. However, estimating the amount and location of the contaminated backfill is not possible due to the lack of complete historical records detailing the location of contaminated backfill and estimates of contamination levels.

5.2.3.2 CPP-15. CPP-15 is near the site of the former solvent burner and is located just outside the tank farm boundary near the southeast corner of Building CPP-605 (Figure 4-1). CPP-15 was a release in 1974 of approximately $100 \mathrm{~L}$ of kerosene and condensate from the main INTEC stack onto the ground. The bulk of the contamination was removed shortly after the release and during the removal of the solvent burner and organic waste storage tank in 1983. The site was excavated in 1995 to a depth of $10 \mathrm{ft}$ or until clean alluvium was encountered, whichever came first. This information is confirmed by the low radionuclide activity (consistent with backfill) in the 2004 soil samples (see Table 5-3) from the near-surface locations and the high levels of radiological contamination encountered below approximately $10 \mathrm{ft}$ (9.9-11.3 ft below grade level). A concrete transformer pad and electrical duct banks are located on top of Site CPP-15.

5.2.3.3 CPP-16. Site CPP-16 is between underground tanks WM-180 and WM-181 (see Figure 4-2). CPP-16 was a release in January 1976 of noncontaminated service wastewater with about 5\% PEW evaporator concentrate. An estimated 150 gal, containing $1.4 \mathrm{Ci}$, leaked in an unlined gravel-bottomed manhole at a depth of $5.7 \mathrm{ft}$. The manhole was replaced when Valve Box C-8 was installed during the ICPP Radioactive Liquid Waste System Improvement project in 1977 and much of the contaminated soil removed. The site has been disturbed during construction activities. This was a no action site under OU 3-13 that was transferred to OU 3-14 for evaluation as part of CPP-96.

5.2.3.4 CPP-20. Site CPP-20 is located on top of the berm immediately north of Building CPP-604 (see Figure 4-2) and overlaps Site CPP-25. The source of contamination to the ground surface was low-activity waste from temporary hoses used for unloading waste from tank trucks prior to 1978 . The total volume was estimated at approximately 100 gal of waste containing $16 \mathrm{mCi}$ of activity. Leaks from the system were observed and cleaned up at the time of the leak. The entire waste unloading area was 
excavated in the early 1980s during installation of new waste transfer lines from CPP-601 to CPP-604 and Valve Box C-32 to waste tanks WL-132 and WL-133.

5.2.3.5 CPP-24. CPP-24 is the site near Tank WM-180 (see Figure 4-2) where a bucket (approximately $1 \mathrm{gal}$ ) of low-activity liquid waste was dumped on the ground on February 15, 1954. The incident report indicates that cleanup of the contaminated soil began immediately and none of the contamination is expected to remain at the site. This was a no action site under OU 3-13 that was transferred to OU 3-14 for evaluation as part of CPP-96.

5.2.3.6 CPP-25. Site CPP-25 (see Figure 4-2) is located on top of the berm immediately north of Building CPP-604 and overlaps Site CPP-20. The ground surface was contaminated on August 28, 1960, with approximately 10 gal of waste containing approximately $0.5 \mathrm{Ci}$ bound for underground tank WL-102. The contaminated soil was immediately removed. As described for CPP-20, the entire area was thoroughly excavated in the early 1980s during construction work to install new waste transfer lines. Therefore, little, if any, of the original contamination remains in the area.

5.2.3.7 CPP-26. Site CPP-26 is located in the northeast corner of the tank farm (see Figure 4-2). The ground surface was contaminated on May 10, 1964, when steam lines used for decontamination failed. The contaminated area was large due to dispersion by high winds at the time of the leak, which was estimated at $2 \mathrm{gal}$ of mist containing approximately $15 \mathrm{Ci}$. Much of the surface contaminated by the release was disturbed by subsequent construction activities and has been covered with $2 \mathrm{ft}$ of soil, a 20-mil-thick membrane liner, and an additional 6 in. of soil to prevent the liner from blowing away. Therefore, the contamination from the steam release would be expected to be approximately $2.5 \mathrm{ft}$ bgs in the tank farm area.

5.2.3.8 CPP-27/33. Site CPP-27/33 is located east of CPP-604 (see Figure 4-2). The two sites were contaminated by the same source but encountered in two separate construction and excavation activities. The release occurred in the mid-1960s when transfers of nitric acid solution from the WCF to the PEW evaporator backed up (via a drain line) into the carbon-steel tank farm pressure relief line. The acidic solution dissolved the carbon-steel line and then leaked into the surrounding soil. The release, $12 \mathrm{ft}$ bgs, contained approximately 540 gal of WCF scrub solution with approximately 1,500 Ci of activity and an additional 500 gal of low-activity, 4.5 molar nitric acid waste. The soil contaminated by these releases was excavated in 1974 to basalt for the CPP-604 basement and again in 1983 while excavating soil to replace Tank WL-102. Approximately $14,000 \mathrm{yd}^{3}$ of contaminated soil were removed from the site and disposed of at the Radioactive Waste Management Complex. The remaining 12,000 $\mathrm{yd}^{3}$ were disposed of in trenches located in the northeast corner of INTEC. ${ }^{\mathrm{b}}$ The excavated area was backfilled using the stockpiled clean soil and clean off-Site soil, and a portion of the area was covered by an asphalt road. This was confirmed by soil samples collected every $4 \mathrm{ft}$ to basalt in 2004 (see Table 5-3). The remaining low levels of contamination are consistent with backfill.

5.2.3.9 CPP-28. Site CPP-28 is located a few yards south of Tank WM-181 (see Figure 4-2). In the early $1970 \mathrm{~s}, 230$ gal of first-cycle waste (with an estimated activity of $18 \mathrm{Ci} /$ gal) leaked from a waste transfer line $7 \mathrm{ft}$ bgs that had a hole accidentally drilled in it during construction. A total of $56 \mathrm{yd}^{3}$ of contaminated soil containing an estimated 3,000 $\mathrm{Ci}$ of gross radionuclides was removed from the release site. The original line and the other similarly constructed line with split carbon/stainless-steel encasement were removed and replaced with a system having welded, stainless-steel, pipe-in-pipe encasement. The site was disturbed during the 1993-1996 tank farm upgrades. As confirmed by sampling results (see Table 5-3), contamination was removed to a depth of $8 \mathrm{ft}$ and replaced with low-activity backfill. The site

b. These trenches were identified as CPP-34 in the OU 3-13 ROD and were remediated as a Group 3 site during OU 3-13 RD/RA. 
is adjacent to CPP-79. The deeper contamination below $28 \mathrm{ft}$ is associated with the release at CPP-79 (deep).

5.2.3.10 CPP-30. Site CPP-30 is located just west of the four-pack tanks (WM-187 through WM-190) (see Figure 4-2). The ground surface around the valve boxes was contaminated with a maximum of $10 \mathrm{~mL}$ of first-cycle raffinate on June 2, 1975, during activities associated with valve maintenance. Cleanup of the contamination commenced immediately after the incident occurred, which included removal of contaminated soil. This was a no action site under OU 3-13 that was transferred to OU 3-14 for evaluation as part of CPP-96.

5.2.3.11 CPP-31. Site CPP-31, located between the westernmost six tanks (WM-180 to WM-185, see Figure 4-2), is associated with a large release during transfer of SBW from Tank WM-181 to Tank WM-180 in 1972. An estimated 18,600 gal containing approximately 30,000 Ci of activity were released at approximately $6 \mathrm{ft}$ bgs. It is the site with the largest release of curies in the tank farm and accounts for a vast majority of the radioactivity (greater than $87 \%$ of the Sr-90 and Cs- 137 activity in OU 3-14). Table 5-3 shows concentrations in 2004 of the COCs remaining in the alluvium. Following discovery of the leak, the carbon-steel line was cut and capped. No cleanup at this site has been performed. Results from the OU 3-14 and previous investigations indicate that a significant amount of contamination remains in the alluvium. Most of the Cs-137 contamination released at CPP-31 remains in the alluvium, while much of the Sr-90, which was more mobile, migrated into perched water and the interbeds.

5.2.3.12 CPP-32E. Site CPP-32E, also known as CPP-32A in some earlier documents, is a small site located west of the four-pack tanks (WM-187 to WM-190) near the southwest corner of Site CPP-30 (see Figure 4-2). Site CPP-32E was contaminated in December 1976 with liquid that dripped to the ground from the equipment used to sample liquid in the Valve Box B-4 sump. The amount of liquid that contaminated the soil was approximately $2 \mathrm{~mL}$, but with high activity (about $1 \mathrm{Ci} / \mathrm{L} \mathrm{Cs-137).} \mathrm{The} \mathrm{site} \mathrm{was}$ covered with $2.5 \mathrm{ft}$ of soil and the tank farm membrane in 1977.

5.2.3.13 CPP-32W. Site CPP-32W, also known as CPP-32B in some earlier documents, is located near Tank WM-186 (see Figure 4-2). CPP-32W is the result of a release of 1 gal of slightly contaminated water ( $5 \mathrm{mCi}$ of activity) from a temporary, aboveground piping system that existed in the mid-1970s. This site has since been covered with $2.5 \mathrm{ft}$ of soil and the tank farm membrane.

5.2.3.14 CPP-58. Site CPP-58 is located outside the tank farm adjacent to the Building CPP-604/605 complex (see Figure 4-2). The site was contaminated by three leaks of service wastewater at $6 \mathrm{ft}$ bgs (one each in 1976, 1977, and 1980) and a nitric acid spill. The volume is estimated at 1,000 gal. CPP-58 contains sites that were referred to in some earlier documents as CPP-58A (also known as CPP-58E) and CPP-58B and newly identified sites in the area. The boundary was changed under OU 3-14 to exclude OU 3-13 Group 2 sites under buildings. Numerous excavations have occurred throughout the site. Contaminated soil removed during the TFIA excavation activities was disposed of at ICDF.

5.2.3.15 CPP-58W. Site CPP-58W is located in the yard about halfway between Buildings CPP-601 and CPP-604, due east of CPP-709 (see Figure 4-2). Previous OU 3-13 documents incorrectly identified the location of the site outside the tank farm boundary. Site CPP-58W was contaminated in August 1954 by a leak from a concrete pipe, $6-8 \mathrm{ft}$ bgs, containing the CPP- 604 service wastewater. The service wastewater included slightly contaminated PEW evaporator condensate. The amount of waste that leaked was likely not more than 1,000 gal and contained approximately $40 \mathrm{mCi}$ of activity. This site was disturbed when the leaking portion of the pipe was replaced by iron pipe but no documentation was found describing cleanup. 
5.2.3.16 CPP-79 (shallow). OU 3-14 determined that there were two releases at CPP-79, shallow and deep. Site CPP-79 (shallow) is northeast of the CPP-604 tank vault (see Figure 4-2). CPP-79 was contaminated by a leak of 2,650 gal of PEW evaporator feed solution containing approximately $2.8 \mathrm{Ci}$ of activity that caused low-activity contamination in a shallow area ( $9 \mathrm{ft} \mathrm{bgs})$ in 1986 . This site was disturbed during the 1993-1994 tank farm upgrade project. The soil above $16 \mathrm{ft}$ bgs is consistent with backfill (see Table 5-3).

5.2.3.17 CPP-79 (deep). Site CPP-79 (deep) was contaminated by a release in the late 1960s to early 1970s of 400 gal of first-cycle waste, PEW, and SBW when Teflon flange gaskets failed in two valve boxes. Because the exact proportion of each waste stream was unknown, it was conservatively assumed that the release was all first-cycle waste and contained approximately 1,800 $\mathrm{Ci}$ of activity. Some of the leaking solution went into the tile pipe encasements that penetrated the floors of the valve boxes and into a horizontal encasement $30 \mathrm{ft}$ below the surface of the tank farm. The site extends under two different shallow releases, CPP-79 (shallow) and CPP-28. Personnel discovered the valve leak in the 1970s when looking for the source of the CPP-28 contamination, and they replaced the gaskets with radiation-resistant material. During an upgrade project in the 1990s, the valve boxes and associated tile-encased lines were replaced to comply with HWMA/RCRA requirements.

5.2.3.18 CPP-112. Site CPP-112 is a potential release from the tank farm concrete containment vault (CPP-784) around Tank WM-184 (see Figure 4-2). On November 18, 2003, approximately 2,000 gal of deionized water were used to rinse down the interior sides of the concrete vault containing stainless-steel tank WM-184. This deionized water/rinsate was then pumped into Tank WM-184. The quantity of water possibly lost was measured at 1,000 gal, less than the level of accuracy $(2,000$ gal) of the two devices used to measure the flow. Therefore, it was not possible to conclusively determine whether 1,000 gal were missing. Duplicate samples of the deionized water/rinsate were taken from the vault sumps for analysis. The results indicated the deionized water/rinsate was nonhazardous (i.e., no constituents exceeded the HWMA/RCRA action limits).

More information on the tank/vault configuration and analytical results of the vault water appear in the new site identification information form for CPP-112 (ICP 2005d). Although a release to the environment was not likely, a conservative source term for CPP-112 was developed based on assuming that 1,000 gal leaked and that the water contained the maximum concentration of the sample or the duplicate. This resulted in an assumed source term of $57 \mu \mathrm{Ci}$.

5.2.3.19 No Action Sites (CPP-102-CPP-110, CPP-113-CPP-116, CPP-125, CPP-126, and CPP-128). Since the signing of the OU 3-13 ROD, 16 previously unidentified sites have been discovered at INTEC outside the tank farm that the Agencies added to OU 3-14. These sites are discussed below.

Thirteen sites, CPP-102 to CPP-110 and CPP-113 to CPP-116, are shallow injection wells that received steam condensate discharges from two boiler plants that supplied steam to various buildings and structures throughout INTEC. The location of these wells is depicted on Figure 5-2. As a result of a review of historical information and a qualitative risk screening (Bragassa 2004a, 2004b), the Agencies determined that no action is appropriate due to the low risk from the CERCLA hazardous substances associated with steam condensate at these sites. Soil at three of the sites (CPP-106, CPP-107, and CPP-108) is contaminated with petroleum. The Agencies noted that when these three sites exit the CERCLA process as no action sites, the State of Idaho requirements for assessing releases of petroleum will need to be addressed. This process has been initiated with DEQ. 


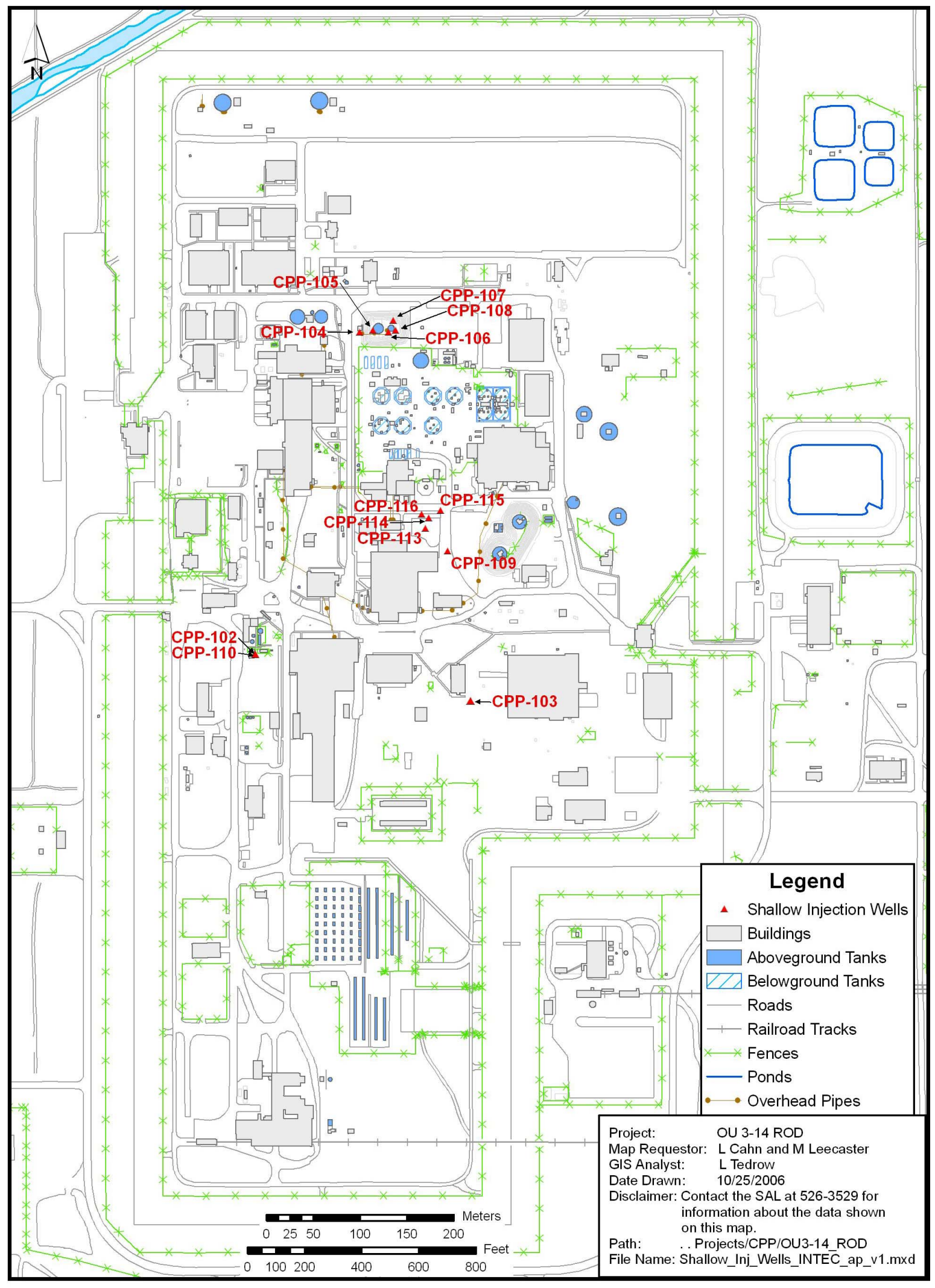

Figure 5-2. Location of shallow injection wells. 
CPP-125 consists of leaks from a 1-1/2-in. transfer line that carries nonradioactive, nonhazardous waste steam condensate to the service waste system for disposal. The steam condensate from this system meets the requirements for the Wastewater Land Application Permit. Past leaks in this line at a location north of Building CPP-1618 have been repaired as recently as July 2002. Because this system was designed to transfer nonhazardous, nonradioactive waste, there is no reason to believe that hazardous or radioactive substances were released to the environment from this pipe. The approximate location of CPP-125 is shown on Figure 4-2.

CPP-126 consists of a leak from a flange in a 20-in. transfer line used to convey service wastewater for disposal. The service waste system was designed to transfer nonradioactive, nonhazardous waste. In June 1989, during an upgrade to the service waste system, a leak was observed at a flange and repaired by tightening the flange. The wastewater in the transfer line is nonhazardous, is continuously monitored for radioactivity, and meets the requirements for the Wastewater Land Application Permit. If radioactivity is detected, the monitoring system is designed to reroute the water to a holding tank. Therefore, no unacceptable risk to human health or the environment exists because of the flange leak. The approximate location of CPP-126 is shown on Figure 4-2.

CPP-128 consists of a leak from a 4-in. transfer line that carries steam condensate from the CPP-649 Atmospheric Protection System to the service waste system for disposal. The pipe failed because steam with temperatures in excess of the temperature rating for the pipe epoxy was delivered through the system. The leak was repaired in 1990. Because this system was designed to transfer only nonhazardous, nonradioactive waste, there is no reason to believe that hazardous or radioactive waste was released to the environment from this pipe. The approximate location of CPP-128 is shown on Figure 4-2.

The OU 3-14 RI/BRA evaluated CPP-102 through CPP-110 and identified that no action under CERCLA was necessary due to the lack of an unacceptable risk associated with the discharge of the steam condensate to these shallow injection wells. The OU 3-14 RI/BRA did not include the most recent new sites (CPP-113-CPP-116, CPP-125, CPP-126, and CPP-128). Sites CPP-113 through CPP-116 have been added to this ROD because the discharges of steam condensate were at levels and quantities that would not pose an unacceptable risk. The Agencies identified that Sites CPP-125, CPP-126, and CPP-128 had releases of nonradioactive, nonhazardous steam condensate or service wastewater and that no action is also appropriate for these sites. A more detailed discussion of the releases associated with these sites can be found in the New Site Identification forms in the Administrative Record (ICP 2005a, b, c).

Upon finalization of the CERCLA no action decision, these sites will exit the CERCLA process and the requirements of the State of Idaho for abandonment of shallow injection wells and assessment of petroleum releases will be met, as applicable to these sites.

\subsection{Geology}

The INL Site is located in the Eastern Snake River Plain and occupies $890 \mathrm{mi}^{2}$ (570,000 acres). The portion of the plain occupied by the INL Site may be divided into three minor physiographic provinces: a central trough that extends from southwest to northeast through the INL Site (see Figure 5-3) and two flanking slopes that descend to the trough, one from the mountains to the northwest and the other from a broad lava ridge on the plain to the southeast. The slopes on the northwestern flank of the trough are older lava flows and younger alluvial fans originating from sediments of Birch Creek and the Little Lost River. The land formations on the southeast flank of the trough were created by basalt flows that spread northeastward onto the INL Site from the Axial Volcanic High. The lavas that erupted along the Axial Volcanic High built up a broad topographic swell directing the Snake River to its current course along the southern and southeastern edges of the plain. This ridge effectively separates the drainage of mountain 


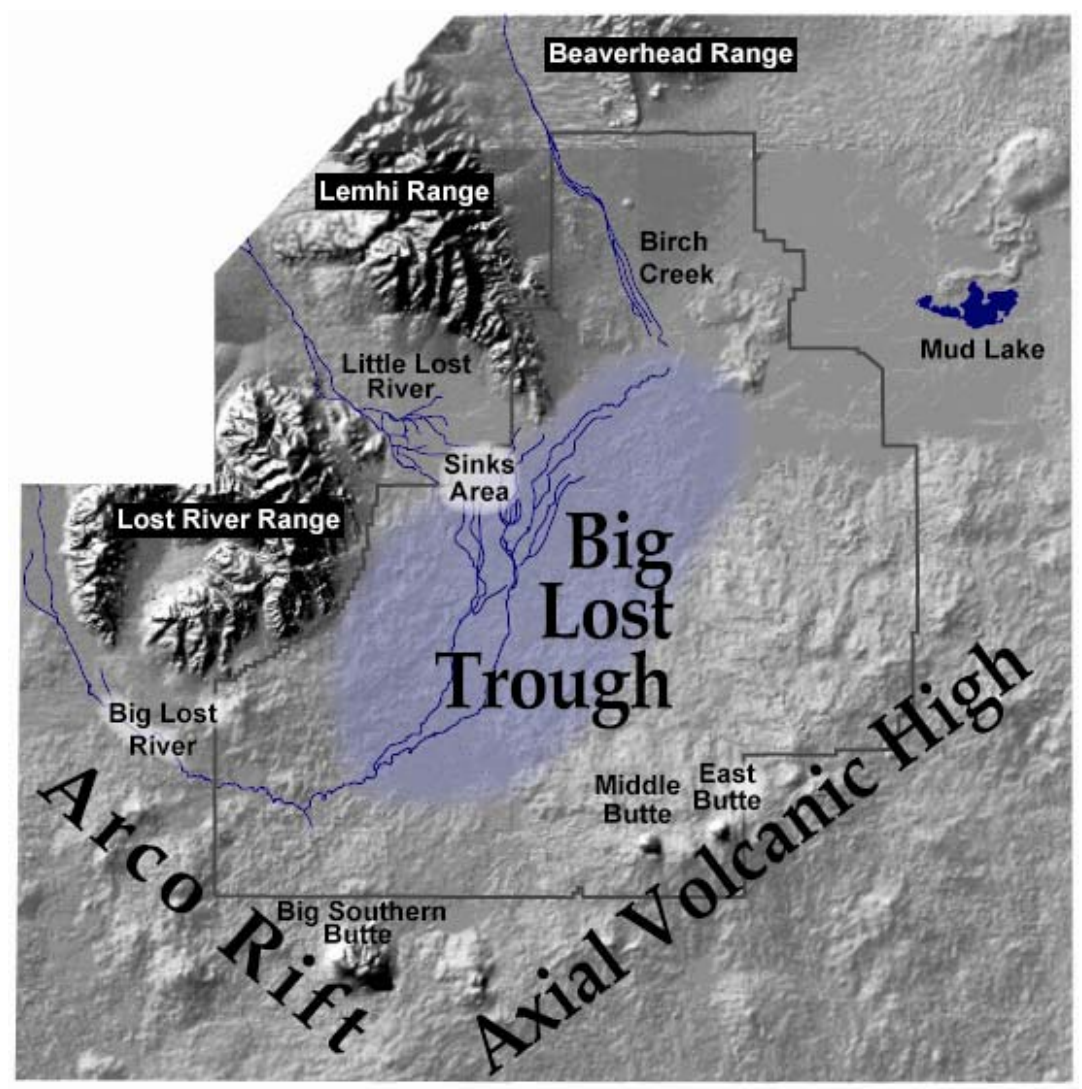

Figure 5-3. Geologic features in the area surrounding INTEC.

ranges northwest of the INL Site from the Snake River. Big Southern, Middle, and East Buttes are aligned roughly along this zone. These rhyolitic domes erupted through older flat-lying basalts of the Axial Volcanic High. Their bases were then covered in the mid-to-late Pleistocene by younger basalts that erupted from the Axial Volcanic High.

INTEC is located in the south-central portion of the INL Site (see Figure 1-1) and is constructed on relatively thick, gravelly, medium-to-coarse alluvial deposits. The tank farm, which covers 4 acres in the northern central portion of INTEC, was constructed in an area that originally had approximately $40 \mathrm{ft}$ of alluvium. The alluvial material was excavated to, and in some cases up to $20 \mathrm{ft}$ into, the underlying basalt. Few, if any, original stratigraphic layers remain in the tank farm alluvium.

\subsection{Surface Water Sources}

The migration of contaminants at OU 3-14 is influenced by infiltration of surface water. The two natural sources of surface water are precipitation and the BLR (when flowing).

\subsubsection{Big Lost River}

The BLR is an intermittent stream that flows north through the INL Site to its terminus at the Lost River sinks, where all of the water infiltrates into the ground. There is a U.S. Geologic Survey (USGS) gaging station at Lincoln Boulevard (northwest corner of the INTEC facility). When flow occurs, peak flows are typically in June and July due to snowmelt, and there is often no flow in the river during the winter months. BLR flows are regulated at Mackay Reservoir, which is located approximately 40 miles to 
the northwest of the INL Site. Flows that reach the INL Site may be diverted to the flood control "spreading areas" located southwest of the Radioactive Waste Management Complex by the INL diversion dam. Water that is not diverted to the spreading areas continues to flow northward across the INL Site in a shallow channel to its terminus at the Lost River sinks. Flow in the sinks is lost to evaporation and infiltration.

The channel of the BLR lies within $100 \mathrm{ft}$ of the northwest corner of the INTEC facility (Figure 5-4). It has been straightened and bermed in the vicinity of INTEC. The average elevation of the INTEC facility $(4,917 \mathrm{ft})$ is about $9 \mathrm{ft}$ higher than the elevation of the BLR channel immediately to the northwest and is about $5 \mathrm{ft}$ higher than the elevation of the BLR berm. An extensive study of the BLR floodplain was completed in 2005. The study concluded that the tank farm is not in the 100-year floodplain of the BLR (BOR 2005).

\subsubsection{Precipitation}

Rain and snowmelt periodically infiltrate into the gravelly alluvium in and around the INTEC facility. Rapid snowmelt and rainwater flowing over partially frozen ground can cause ponding of water in low areas. The tank farm is mounded, but water accumulates in low areas outside the tank farm. Even though the average annual precipitation $(22.1 \mathrm{~cm} / \mathrm{yr})$ is much less than the pan evaporation rate $(109 \mathrm{~cm} / \mathrm{yr})$, water from snowmelt or heavy rains infiltrates into the ground to depths where it cannot evaporate. This water then continues to move downward until it recharges perched water and the aquifer.

The combination of coarse surficial sediments and lack of vegetation permits infiltration of a large fraction of the natural precipitation. Furthermore, many areas at INTEC are occupied by buildings or are paved with asphalt or concrete. Precipitation falling on building roofs is routed to downspouts. Water falling on paved surfaces tends to flow laterally to the pavement edge, where it may then flow into drainage ditches. The ditches are mostly unlined, and a significant fraction of infiltration likely occurs along the ditches. Therefore, infiltration may actually be greater due to the impervious areas, which focus much of the surface run-off into gravelly areas or unlined drainage ditches.

The degree of correlation between the timing of upper shallow perched water level changes and calculated "relative soil moisture" strongly indicates that seasonal water level changes are primarily due to infiltration of rain and snowmelt rather than recharge from BLR streambed infiltration (DOE-ID 2006b).

\subsection{Hydrogeology}

A series of basalt flows and sedimentary interbeds underlie the surficial alluvium. Water that infiltrates downward through the alluvium encounters zones of low-permeability interbed material, low-permeability basalt flows, and high-permeability basalt flows. Infiltrating water from the surface tends to flow vertically downward but may flow laterally where low-permeability units are present that impede downward flow. The lower-permeability zones allow local accumulations of water that result in areas of high moisture content or saturation. In regions receiving sufficient recharge waters, perched water bodies form and persist as long as the recharge sources are present.

Perched water zones have been present at various depths within the 460 -ft-thick vadose zone beneath INTEC since at least as early as 1956 (Robertson, Schoen, and Barraclough 1974). Perched water exists under northern INTEC. The northern perched water system consists of the shallow and deep perched water zones. The northern shallow perched water system has been further divided into the upper shallow and lower shallow perched water zones, which generally correspond with the 110- and 140-ft sedimentary interbeds. The deep perched water zone coincides with the 380 -ft interbed. 


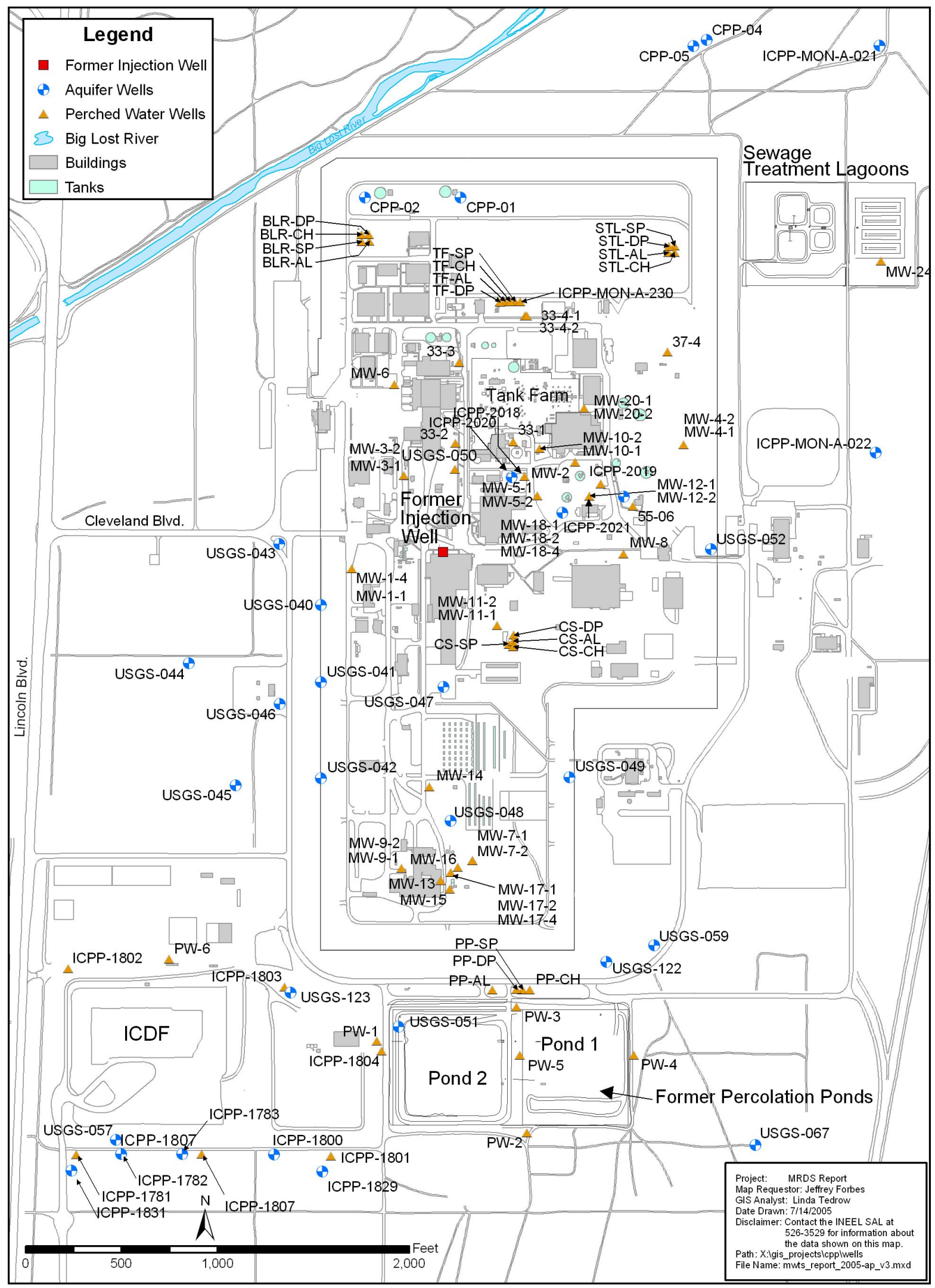

Figure 5-4. Big Lost River (upper left) and monitoring wells in the vicinity of INTEC. 


\subsubsection{Northern Shallow Perched Water}

Figure 5-5 shows the southern and eastern extent of northern shallow perched water in 2006. The northern shallow perched water level elevation data suggest that lateral flow in the shallow perched water beneath the northern INTEC area is generally to the southeast, which is consistent with the southeasterly dip of the top of the 110- $\mathrm{ft}$ interbed beneath and south of the tank farm (DOE-ID 2006b).

Based on an analysis of downhole neutron moisture logs performed at the INTEC tank farm during 1994, the annual precipitation infiltration rate inside INTEC has been estimated to be approximately $18 \mathrm{~cm} / \mathrm{yr}(7.1 \mathrm{in} . / \mathrm{yr}$ ) or about $85 \%$ of the total average annual precipitation (Appendix B of DOE-NE-ID 2006a). This equates to 0.59 acre-feet of precipitation infiltration per acre, or an infiltration rate of $193,000 \mathrm{gal} / \mathrm{acre}$. The total fenced area of INTEC is approximately 175 acres. Therefore, precipitation infiltration for the entire facility totals approximately $34 \mathrm{M} \mathrm{gal} / \mathrm{yr}$. Because the northern portion of INTEC that is over the shallow perched water accounts for about $60 \%$ of the total facility area, approximately $20 \mathrm{M} \mathrm{gal} / \mathrm{yr}$ of precipitation infiltration recharges the northern perched water, which contains the highest concentrations of radionuclides. This volume is comparable to estimates of the upper shallow perched water volume (6 to $18 \mathrm{M}$ gal). Taken together, this information indicates that the upper shallow perched water is being continuously replaced by recharge, and the mean residence time for the upper shallow perched water is estimated as less than 1 year.

Although the BLR loses much water to streambed infiltration, BLR infiltration appears to have little influence on the shallow perched water as far away from the river as under the tank farm. No response has been observed in the shallow perched water wells surrounding the tank farm from flows in the BLR. Rather, a combination of precipitation infiltration (rainfall and snowmelt) and discharges and leaks of water from facility pipelines appears to account for continued recharge of the perched water beneath the northern part of INTEC (Figure 5-5). A detailed analysis of shallow perched water level fluctuations indicates that the combined recharge from precipitation infiltration and leaks from INTEC pipelines is more important than BLR streamflow infiltration with respect to formation of the shallow perched water beneath the tank farm area (DOE-ID 2006b). This conclusion is consistent with the observation that the northern shallow perched water persisted during 2002-2005, in spite of the fact that the BLR did not flow during that time.

\subsubsection{Northern Deep Perched Water}

Deep perched water occurs approximately 380 to $400 \mathrm{ft}$ below the surface and generally coincides with the 380-ft sedimentary interbed. Only a few monitoring wells have been completed in the northern deep perched water. USGS-50 and BLR-DP have always had water in them. Wells MW-18-1 and TF-DP have gone dry since they were installed and Wells STL-DP, ICPP-2020-DP, and ICPP-2021-DP have been essentially dry since they were installed. It is difficult to estimate the lateral extent and continuity of the deep perched water zone from the limited number of wells to that depth.

\subsubsection{Snake River Plain Aquifer}

The SRPA underlies the entire INL Site and is among the nation's most productive aquifers. It is the primary source of water for domestic, municipal, and industrial use in southeastern Idaho and also provides large quantities of water for agricultural irrigation. The SRPA consists of a thick sequence of Quaternary basalt flows, some of which are separated by thin sedimentary interbeds deposited at the former land surface during the periods between volcanic eruptions. 


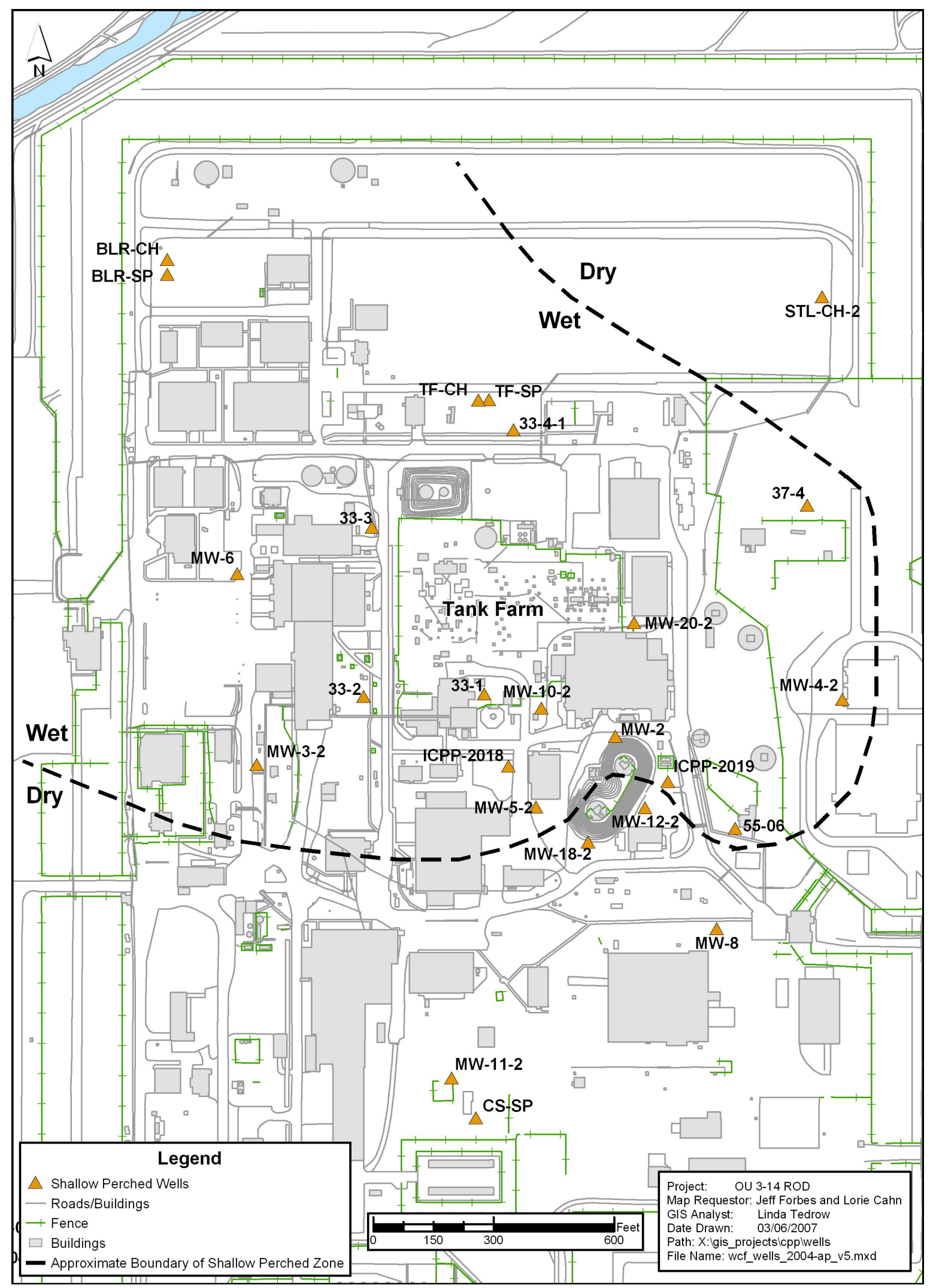

Figure 5-5. Approximate southern and eastern extent of northern shallow perched water in 2006. 
Groundwater flow in the SRPA occurs predominantly through fractures (joints) in the basalt and along rubble zones at flow contacts (bedding planes). In the eastern SRPA, regional groundwater flow is to the southwest. Recharge occurs primarily in mountain-front areas near the Yellowstone Plateau and Lost River Ranges. Lesser recharge sources include seepage into the bed of the BLR (when flowing) and infiltration of irrigation water applied to agricultural lands near Howe and Mud Lake to the north and northeast of the INL Site, respectively. On a local scale, groundwater flow directions may differ from regional flow paths.

Hydraulic conductivities beneath INTEC are among the highest anywhere in the INL Site. The very large hydraulic conductivities and fractured nature of the basalt aquifer matrix result in very rapid groundwater flow velocities, typically $5 \mathrm{ft} /$ day in the SRPA near INTEC. Based on observations of H-3 migration from the former injection well, even higher flow velocities occurred when the injection well was in operation (1952-1984) (Robertson, Schoen, and Barraclough 1974).

\subsection{Current Perched Water and Aquifer Contamination}

The perched water beneath northern INTEC and the SRPA was impacted by the OU 3-14 releases described above and the former injection well. During its operation, the INTEC injection well constituted a source of low-level radioactivity to the aquifer and deep perched water. The service wastewater included primarily clean plant cooling water with small amounts of evaporator condensates, demineralizer water, and boiler blowdown water. The condensate contained radionuclides, primarily H-3. The well was designed to discharge wastewater directly into the SRPA. However, the casing of the INTEC injection well is known to have failed twice, allowing service wastewater to flow out into the deep vadose zone (DOE-ID 2004c). Contamination of the deep perched water zone also occurred for approximately 1 month during September-October 1970 when service waste was temporarily sent to deep perched monitoring well USGS-50 during reconstruction of the injection well. The history of the former injection well was summarized in EDF-3943, "INTEC Injection Well: Summary of Historical Information and Groundwater Quality Trends." Since it was plugged with cement grout and abandoned in 1989, the former INTEC injection well is not a continuing source of contaminants to the aquifer. However, drain-out of service waste from the deep perched zone continues to contribute a slow flux of H-3, Sr-90, I-129, and other radionuclides to the SRPA (DOE-ID 2004c).

The maximum 2005 concentration in the perched water and the SRPA for the OU 3-14 groundwater COCs is shown on Table 5-4 along with the well where the maximum concentration occurred (see Figure 5-4 for a map of well locations). For Sr-90, the highest concentrations occur in the shallow perched water, and concentrations decrease toward the aquifer. For technetium-99 (Tc-99), the highest concentrations occur in the aquifer. The maximum I-129 concentrations are around the MCL of $1 \mathrm{pCi} / \mathrm{L}$ except in the lower shallow perched water, where it is not detected. The maximum nitrate concentration occurs in deep perched water well MW-1-4, which is near the former injection well.

Sr-90 is the constituent whose concentrations exceed its MCL by the greatest margin in perched water at INTEC (perched water is not a source of drinking water and the MCL is used as a point of reference only). The reasons Sr-90 is a concern for the SRPA include (1) the total (undecayed) inventory of Sr-90 in the known historical liquid releases at the tank farm was approximately 18,000 $\mathrm{Ci}$ at the time of release (DOE-NE-ID 2006a), (2) Sr-90 has a 29-year half-life, (3) Sr-90 can remain somewhat mobile under certain subsurface conditions (unlike many other fission products), and (4) Sr-90 has a high specific activity and relatively low MCL $(8 \mathrm{pCi} / \mathrm{L})$. 
Table 5-4. Maximum 2005 concentrations of COCs in perched water and the SRPA. (Well name shown in italics.)

\begin{tabular}{|c|c|c|c|c|}
\hline & \multicolumn{4}{|c|}{ Contaminants of Concern for the SRPA } \\
\hline & $\begin{array}{c}\mathrm{Sr}-90 \\
(\mathrm{pCi} / \mathrm{L})\end{array}$ & $\begin{array}{c}\text { Tc-99 } \\
(\mathrm{pCi} / \mathrm{L})\end{array}$ & $\begin{array}{c}\mathrm{I}-129 \\
(\mathrm{pCi} / \mathrm{L})\end{array}$ & $\begin{array}{l}\text { Nitrate-N } \\
(\mathrm{mg} / \mathrm{L})\end{array}$ \\
\hline \multicolumn{5}{|l|}{ Water body } \\
\hline Upper shallow perched & $\begin{array}{c}192,000 \\
M W-2\end{array}$ & $\begin{array}{c}43.8 \\
M W-5-2\end{array}$ & $\begin{array}{c}1.3 \\
I C P P-2019\end{array}$ & $\begin{array}{l}24.9 \\
37-4 \\
\end{array}$ \\
\hline Lower shallow perched & $\begin{array}{c}13,100 \\
M W-10-2 \\
\end{array}$ & $\begin{array}{c}349 \\
M W-10-2 \\
\end{array}$ & Not detected & $\begin{array}{c}11 \\
M W-9-2\end{array}$ \\
\hline Deep perched & $\begin{array}{c}120 \\
\text { USGS-50 }\end{array}$ & $\begin{array}{c}31.1 \\
\text { USGS-50 }\end{array}$ & $\begin{array}{c}0.8 \\
\text { USGS-50 }\end{array}$ & $\begin{array}{c}41.4 \\
M W-1-4\end{array}$ \\
\hline SRPA & $\begin{array}{c}35.3 \\
U S G S-47 \\
(\mathrm{MCL}=8) \\
\end{array}$ & $\begin{array}{c}2,900 \\
I C P P-M O N-A-230 \\
\left(\mathrm{MCL}=900^{\mathrm{a}}\right)\end{array}$ & $\begin{array}{c}1.2 \\
U S G S-47 \\
\left(\mathrm{MCL}=1^{\mathrm{a}}\right) \\
\end{array}$ & $\begin{array}{c}13.2 \\
I C P P-2021 \\
(\mathrm{MCL}=10) \\
\end{array}$ \\
\hline
\end{tabular}

In the SRPA, two contaminants (Sr-90 and I-129) exceed the MCLs due to past discharges to the former injection well. As shown on Figure 5-6, Sr-90 concentrations (in pCi/L) in 2005 in the SRPA exceeded the MCL $(8 \mathrm{pCi} / \mathrm{L})$ in nine of 18 monitoring wells. The portion of the plume that exceeds the standard extends $3 / 4$ of a mile downgradient of INTEC, with peak concentrations slowly declining as a result of radioactive decay and dilution/dispersion. The peak concentration in 2005 was $35.3 \pm 0.8 \mathrm{pCi} / \mathrm{L}$ in USGS-47, which is located downgradient of the former INTEC injection well within the INTEC facility. In 2005, I-129 concentrations in the aquifer exceeded the MCL of $1 \mathrm{pCi} / \mathrm{L}$ in one well, USGS-47 $(1.23 \pm 0.01 \mathrm{pCi} / \mathrm{L})$.

Two contaminants in the SRPA, Tc-99 and nitrate as nitrogen (N), exceed the MCLs from historical releases to tank farm soil. In May 2003, groundwater monitoring at aquifer monitoring well ICPP-MON-A-230 just north of the tank farm measured Tc-99 in the SRPA at concentrations approximately three times the derived MCL for Tc-99 of $900 \mathrm{pCi} / \mathrm{L}$. The results of the Tc-99 investigation indicated that the elevated Tc-99 in groundwater at Well ICPP MON-A-230 was most likely attributable to historical liquid waste releases at the tank farm, in particular the Site CPP-31 release (ICP 2004). In 2005, an additional aquifer monitoring well was drilled southeast of the tank farm (ICPP-2021) that also found elevated concentrations of Tc-99 $(1,220 \pm 20 \mathrm{pCi} / \mathrm{L})$. In 2005, the SRPA exceeded the MCL for nitrate as N of $10 \mathrm{mg} / \mathrm{L}$ in one well, ICPP-MON-A-230 (13.2 mg/L).

In contrast to the fission products, none of the actinide elements (uranium [U], plutonium [Pu], neptunium [Np], americium [Am]) have ever exceeded their MCLs in groundwater at or downgradient of INTEC. 


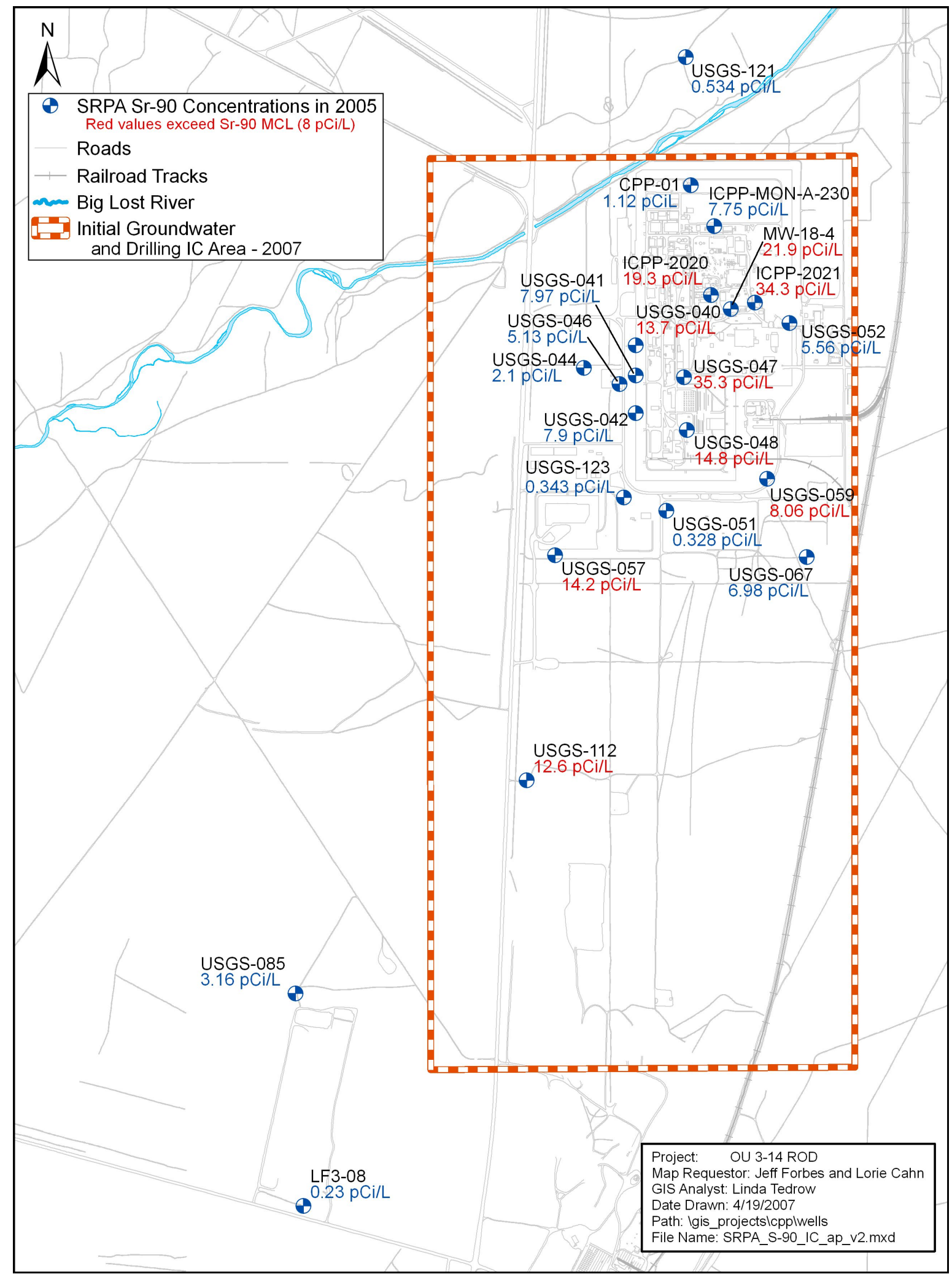

Figure 5-6. Distribution of Sr-90 in the SRPA in 2005 and initial groundwater and drilling institutional control (IC) area. Sr-90 concentrations, in pCi/L, are shown in color. Red values are $>$ MCL, blue $<$ MCL. 


\subsection{Source Term}

To model the release of contaminants into the subsurface and predict the fate and transport of contaminants, a source term was developed to account for the mass or activity released at the WAG 3 CERCLA sites. Approximately 18,000 Ci of Sr-90; 19,000 Ci of Cs-137; $15.5 \mathrm{Ci}$ of Tc-99; $1 \mathrm{Ci}$ of I-129; and $2,850,000 \mathrm{~kg}$ of nitrate are estimated to have been released into OU 3-14 soil and the former INTEC injection well. Table 5-5 shows the relative percentage that each of these sites contributed and the curies or mass for each COC. The former injection well accounted for a large percentage of the total Tc-99 and nitrate released, but the wastewater concentrations were relatively low. However, monitoring results indicate that the current plume in the SRPA that exceeds MCLs for Tc-99 and nitrate likely came from the tank farm sources, rather than the former injection well. The contaminants in the tank farm releases were much more concentrated than those in the injection well.

Table 5-5. Comparison of selected contaminant sources and their relative contributions.

\begin{tabular}{lccccc}
\hline & \multicolumn{5}{c}{ Contaminants of Concern } \\
\cline { 2 - 6 } \multicolumn{1}{c}{ Site } & Sr-90 & Cs-137 & Tc-99 & I-129 & Nitrate \\
\hline CPP-31 & $87 \%$ & $87 \%$ & $21 \%$ & $<1 \%$ & $<1 \%$ \\
CPP-28, -27/33, -79 (deep) & $12 \%$ & $12 \%$ & $2 \%$ & $<1 \%$ & $<1 \%$ \\
All other OU 3-14 sites & $<1 \%$ & $<1 \%$ & $<1 \%$ & $<1 \%$ & $<1 \%$ \\
Former injection well $^{\text {Total release }}$ & $<1 \%$ & $<1 \%$ & $77 \%$ & $99 \%$ & $99 \%$ \\
$\begin{array}{l}\text { a. Ci values reported were at time of release and have not been decayed. Over half of the Cs-137 and Sr-90 reported on this } \\
\text { table has already decayed. }\end{array}$
\end{tabular}

As shown on Table 5-5, Site CPP-31 was the largest radionuclide release in OU 3-14. Site CPP-31 accounts for over $87 \%$ of the total Sr-90 and Cs- 137 released at the tank farm. Sites CPP-28, CPP-27/33, and CPP-79 (deep) account for about 8-12\% of these contaminants, and the remaining OU 3-14 soil sites account for less than 1\% of the radionuclides. Sampling data show that Cs-137 and Sr-90 remain in the soil and that a portion of the Sr-90 has moved downward into the underlying perched water and interbed sediments. Sr-90 concentrations in the perched water decrease with depth. There is no evidence that the Sr-90 from the tank farm releases has yet reached the SRPA. The former INTEC injection well accounted for almost all of the I-129 released at INTEC, but less than 1\% of the Sr-90 and Cs-137. Although the former injection well was a small percentage of the total Sr-90 released at INTEC, it created a Sr-90 plume in the aquifer because the waste was injected directly into the aquifer.

\subsection{Conceptual Model}

Figure 5-7 is a conceptual model of the subsurface that shows the contamination currently beneath INTEC. Some contaminants released to the environment remain in the tank farm soil (Cs-137 and residual Sr-90). Some contaminants have been carried by water from surface sources into perched water, interbeds, and basalt (Sr-90); and other contaminants (Tc-99 and nitrate) have migrated through the subsurface to the aquifer. The concentration of Sr-90 in the perched water decreases with depth as it sorbs to interbeds and basalt during transport. Some contamination in the aquifer and deep perched water zone (Sr-90 and I-129) is from the former INTEC injection well. I-129 concentrations exceed the MCL in a single aquifer monitoring well near the former INTEC injection well. Production wells, which provide drinking water for INTEC, are northeast of INTEC and meet MCLs. Two older production wells in 


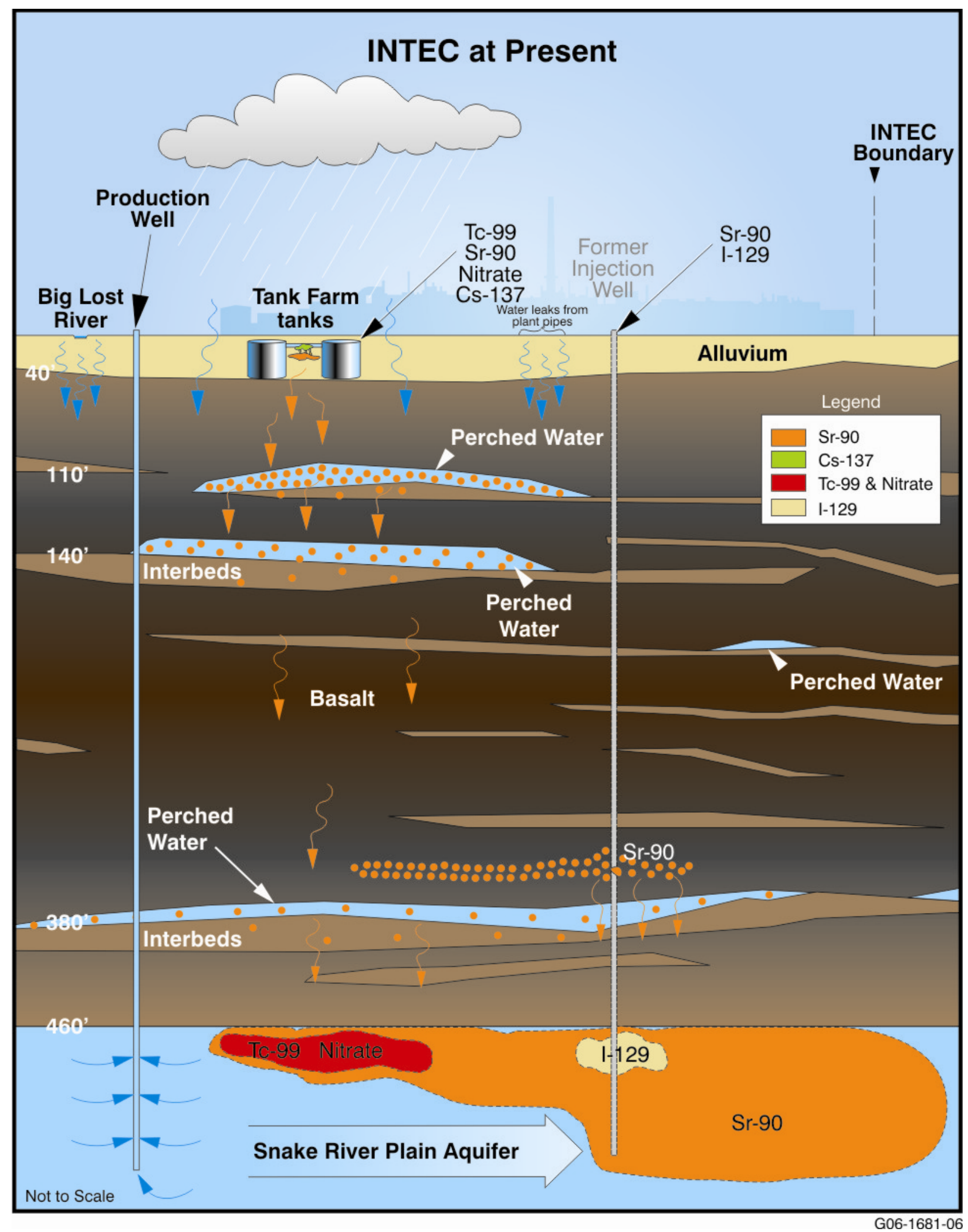

Figure 5-7. Conceptual model of the subsurface showing the contamination beneath INTEC. 
northern INTEC that do not provide drinking water have caused groundwater contaminated with Sr-90 to move to the north against the regional gradient. The deep perched water is contaminated with Sr-90 from historical failures of the casing of the INTEC injection well in the deep subsurface above the aquifer. The former injection well has been plugged and abandoned and is no longer a source of contamination. Infiltration of precipitation and anthropogenic water is the primary driving force for contaminant transport from the perched water, basalt, and interbeds to the aquifer. The BLR does not appear to impact the shallow perched water bodies beneath the tank farm.

The conceptual model provides the basis for the groundwater model, which is used to predict aquifer concentrations in the future to assess risk from the contaminant sources. The conceptual site model, which identifies exposure pathways, exposure routes, and classes of receptors for the risk assessment, is in Section 7.1.

\subsection{Groundwater Modeling}

The OU 3-13 ROD presented modeling results that were inconsistent with subsequent monitoring data. That model overestimated transport and groundwater and perched water concentrations for I-129 and $\mathrm{Pu}$ and underestimated groundwater concentrations for Tc-99. The OU 3-14 model included revised model input parameters to more accurately predict transport.

Modeling was conducted to simulate release and migration of contaminants from the OU 3-13 and OU 3-14 sites, including the former injection well, and to estimate future contaminant concentrations in the SRPA. The updated OU 3-14 source terms are based on descriptions in Section 5 of the RI/BRA (DOE-NE-ID 2006a) that were briefly summarized in Section 5.7 of this ROD. No credit was taken for soil removed from the tank farm and disposed elsewhere. A separate source term for CPP-96 was not developed because it was accounted for in the individual tank farm release sites. The modeling predicts the fate and transport of contaminants over time if no remedial action is taken. The modeling is summarized in Section 8 of the RI/BRA, and details on the modeling can be found in Appendix A of the RI/BRA for all contaminants except Sr-90, which can be found in Appendix J (DOE-NE-ID 2006a).

The numerical code was the same one used in OU 3-13 (the TETRAD simulator, Vinsome and Shook 1993). The model (Version $12.7 \mathrm{~ms}$ ) was updated with new information, and the subsurface structure was incorporated using detailed geostatistical representations of sedimentary units rather than simply representing interbed tops geostatistically and preserving total sediment thickness (effective interbeds) as was done in the OU 3-13 model. Hydraulic properties assigned to the updated model were also assigned geostatistically as opposed to assigning uniform hydraulic properties within each material type. Model parameters specific to contaminant migration, such as partition coefficients, were defined using site-specific information. Reasonable values from the literature were selected when site-specific data were not available. Some contaminants, like Tc-99, I-129, and nitrate, are very mobile- they move at about the same rate as water. Other contaminants, like Cs-137 and Sr-90, are less mobile - their movement is slowed because they attach to the surrounding soil and rock.

The simulation process involved three steps: (1) representation of the time-release of each contaminant at each source location; (2) prediction of the evolution (transport, decay, adsorption, dispersion, etc.) of the contaminant through the vadose zone; and (3) prediction of transport processes in the aquifer. In Step 1, for all contaminants with the exception of Sr-90, the source terms developed in Section 5 were represented as time-varying mass fluxes that were either placed in the vadose zone model for those releases occurring near land surface or into the aquifer model during the periods when the injection well was operative. Simulation Steps 2 and 3 were linked through a mass-flux boundary between the vadose zone and aquifer portions of the model. 
The near-surface release of Sr-90 at Site CPP-31 was treated more rigorously in Step 1 because of the composition of the SBW at that site. Specifically, a geochemical model (TOUGHREACT, $\mathrm{Xu}$ et al. 2004) of the alluvium was necessary to account for the evolution of the SBW release of Sr-90 at Site CPP-31 because of the unusual chemistry (highly acidic and high in salts). Being highly acidic, the waste released at CPP-31 dissolved naturally occurring salts contained in the soil particles (primarily calcium). The dissolved salts competed with the Sr-90 for soil attachment sites. This allowed some of the Sr-90 to migrate rapidly downward into the perched water where the background chemistry existed. Dilution with the background water and contact with the interbed sediments then reduced the Sr-90 mobility allowing most of it to attach to the interbed sediments. Closer to the CPP-31 release area, the naturally alkaline soil eventually neutralized the acidic waste. As infiltrating snowmelt and rainwater dissolved and washed away the salts, the binding strength and the chemistry of the soil was restored to background. This allowed the Sr-90 remaining in the tank farm soil to become tightly bound to the soil. To account for this complex release in the context of simulation Steps 2 and 3, Sr-90 mass flux out of the alluvium predicted by the geochemical model was placed into the TETRAD vadose zone model below the alluvium, and the portion predicted to remain in the alluvium was placed nearer land surface. As with the other contaminants, simulation Steps 2 and 3 were linked through a mass-flux boundary between the vadose zone and aquifer portions of the model accounting for all of the releases of Sr-90.

Predictive modeling was then conducted for each contaminant as far out in the future as necessary to capture the peak arrival(s) in the aquifer. Aquifer model termination dates ranged from 2095 to the year 4587, depending on the contaminant. In all cases, simulated and actual peak aquifer concentrations are stable or trending downward. Peak aquifer concentrations are predicted to decline over time.

Sr-90 is the only contaminant that is predicted to exceed MCLs in 2095 and beyond if no further remedial action is taken to protect groundwater. The geochemical modeling indicates that most of the Sr-90 has migrated into the perched water and interbed sediments. Infiltration of precipitation and discharges of clean INTEC process water would aid desorption of the Sr-90 currently in the perched water in and above the interbed sediments, facilitating downward transport toward the SRPA. The model also predicts that the residual $\mathrm{Sr}-90$ in the tank farm alluvium is relatively immobile (cation exchange) and is an insignificant contributor to the overall groundwater risk. Because of this, remedial action on the contaminated alluvium would not significantly reduce groundwater risk.

If no action is taken, the predicted extent of the Sr-90 plume is shown on Figure 5-8 from 2005 to 2096 and on Figure 5-9 from 2049 to 2151 . The red contour is the MCL ( 8 pCi/L) and the black contour is one-tenth the MCL $(0.8 \mathrm{pCi} / \mathrm{L})$. The model predicts that the maximum concentration in the aquifer will fall below $19 \mathrm{pCi} / \mathrm{L}$ in 2095 and be below the MCL in 2129 , largely as a result of decay and dispersion if no action is taken. The peak measured concentration in 2005 was $35.3 \pm 0.8 \mathrm{pCi} / \mathrm{L}$.

To address specific public concern over the long-lived contaminants $\mathrm{Pu}-239$ and $\mathrm{Pu}-240$, the analysis for these contaminants was extended beyond 2095. Adsorption to soil retards the migration rate of these contaminants, preventing them from reaching the aquifer from the near-surface release sites for thousands of years. Concentrations in the vadose zone and the mass flux of these contaminants into the aquifer were predicted through year 87,594. In the analysis of long-term concentrations, the following were considered:

- $\quad$ Predicted concentrations in the vadose zone - In the vadose zone, the water saturation is less than one, which results in higher contaminant concentrations than would be observed in the aquifer. Additionally, higher water flow velocities occurring in the aquifer dilute the slower water fluxes arriving from the vadose zone. The combined effects result in aquifer concentrations several times smaller than vadose zone concentrations. 


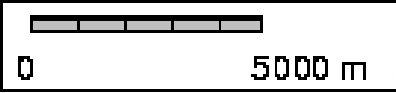

North
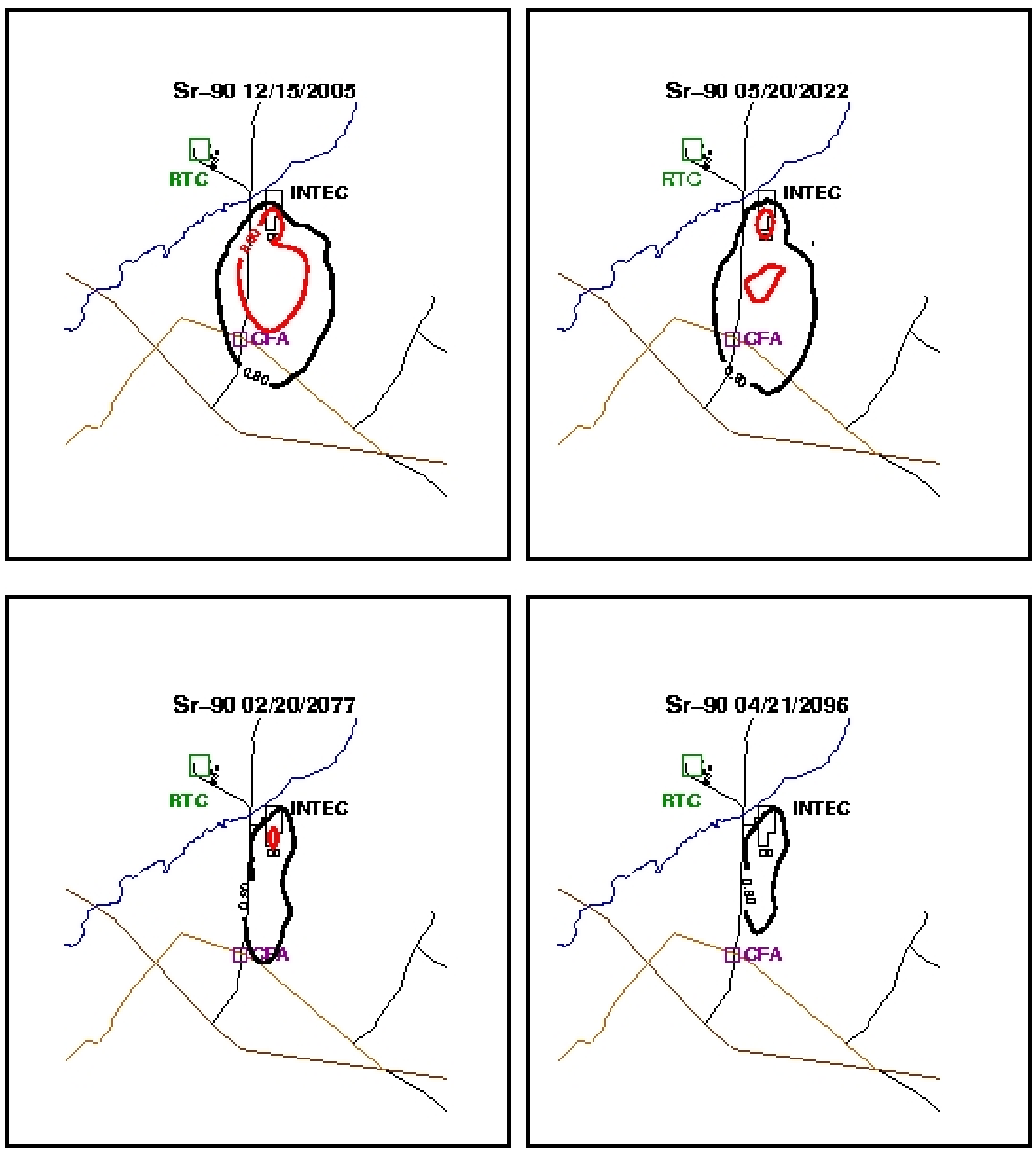

Figure 5-8. Predicted SRPA Sr-90 plumes (in pCi/L) for the years 2005, 2022, 2077, and 2096 if no action is taken. Red contour is the MCL, and black contour is one-tenth the MCL. 

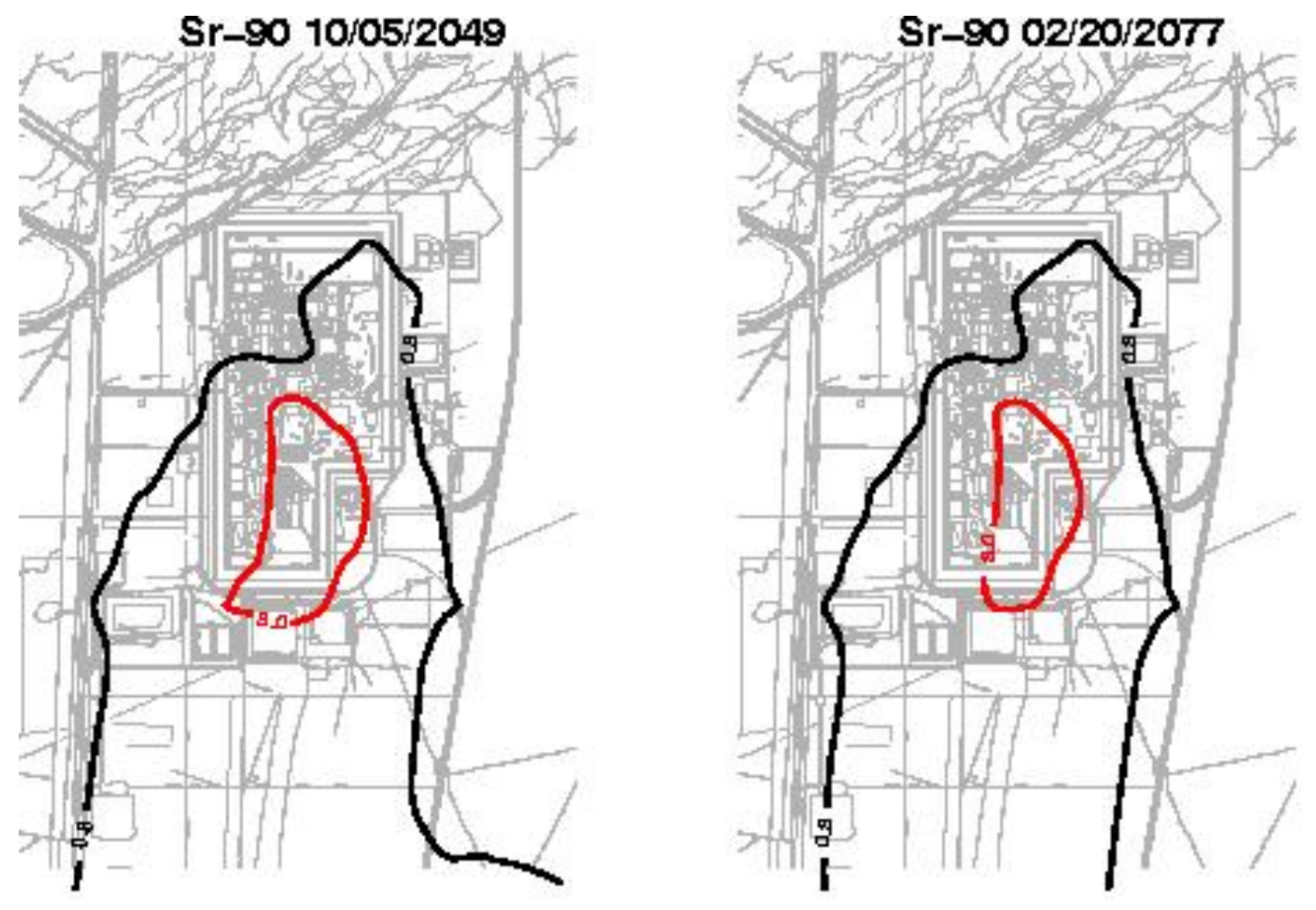

North
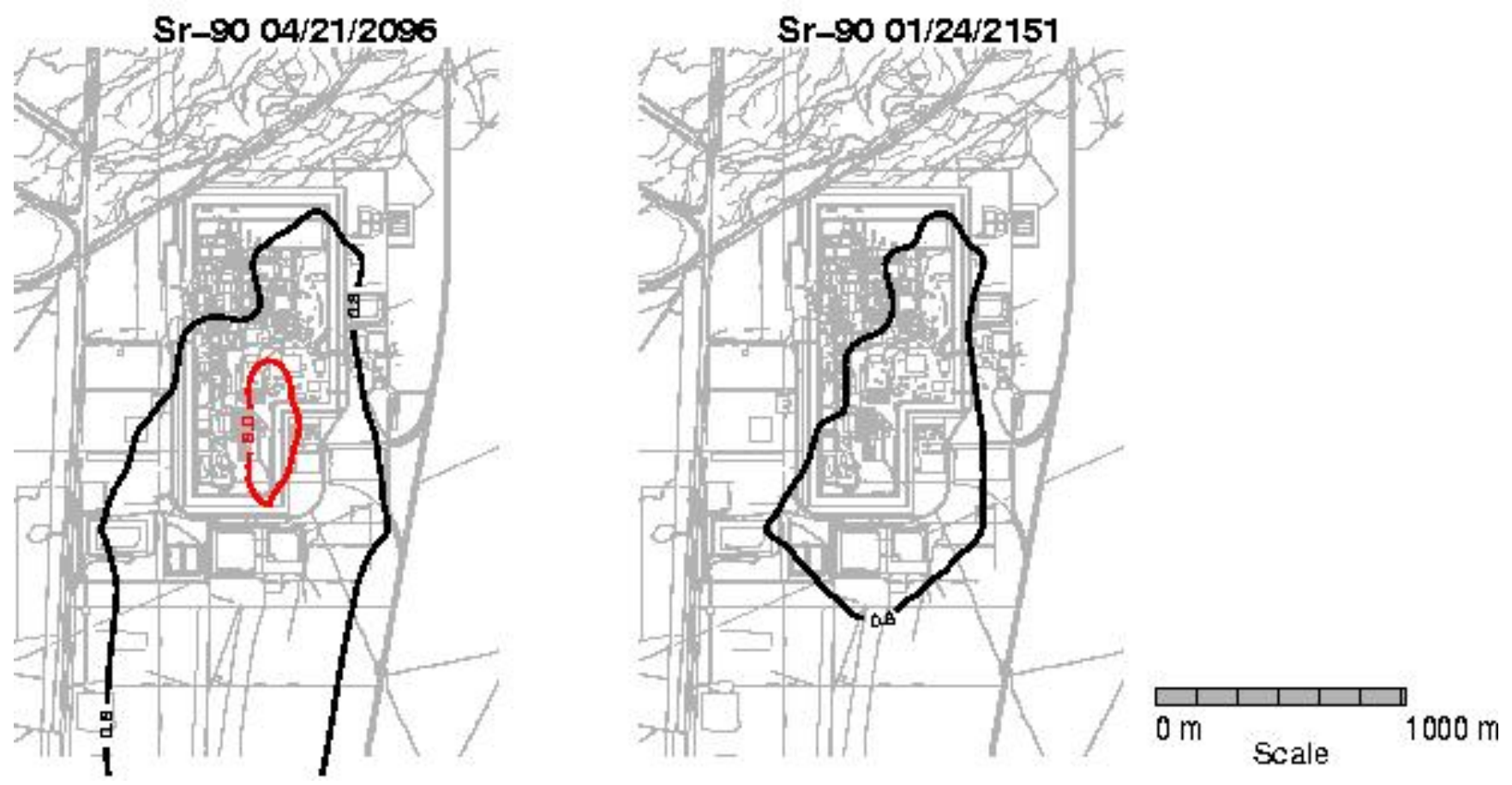

Figure 5-9. Predicted SRPA Sr-90 plumes for the years 2049, 2077, 2096, and 2151 near INTEC if no action is taken. Red contour is the MCL, and black contour is one-tenth the MCL. 
- $\quad$ Predicted mass-flux rates from the vadose zone compared to the mass fluxes that occurred during use of the injection well - The aquifer model incorporated $\mathrm{Pu}-239$ and $\mathrm{Pu}-240$ injection well discharges and predicted the peak aquifer concentrations resulting from those mass fluxes. Injection well mass fluxes can be directly compared to the predicted mass flux arriving from the vadose zone, which allows estimation of the concentration for the very long-term arrival of contaminants from land surface.

For $\mathrm{Pu}-239$, the predicted peak vadose zone concentration occurred in 1973 and was $104 \mathrm{pCi} / \mathrm{L}$. This concentration and retarded migration rate result in a mass flux on the order of $1 \times 10^{-8} \mathrm{Ci} /$ day through the 60,000-year time frame. In comparison, the failed injection well resulted in a mass flux of $4 \times 10^{-9} \mathrm{Ci} /$ day and peak aquifer concentration of $0.03 \mathrm{pCi} / \mathrm{L}$. The slightly higher flux rate arriving from the vadose zone would be expected to result in a peak aquifer concentration on the order of $0.12 \mathrm{pCi} / \mathrm{L}$, which is well below the drinking water standard of $15 \mathrm{pCi} / \mathrm{L}$.

For $\mathrm{Pu}-240$, the predicted peak vadose zone concentration was $19.4 \mathrm{pCi} / \mathrm{L}$, just slightly higher than the drinking water standard of $15 \mathrm{pCi} / \mathrm{L}$. Use of the injection well resulted in an early mass-flux rate of $2 \times 10^{-9} \mathrm{Ci} /$ day during the 1950-2000 time period and a peak aquifer concentration of $0.16 \mathrm{pCi} / \mathrm{L}$. Pu-240 originating from the near-land-surface releases is predicted to arrive much later, with fluxes peaking at $7 \times 10^{-11} \mathrm{Ci} /$ day. This much slower arrival from the vadose zone would be expected to result in a peak aquifer concentration on the order of $0.005 \mathrm{pCi} / \mathrm{L}$, which is also well below the drinking water standard of $15 \mathrm{pCi} / \mathrm{L}$. 


\section{CURRENT AND POTENTIAL FUTURE SITE AND RESOURCE USES}

The INL Site is approximately $890 \mathrm{mi}^{2}$ (570,000 acres). Land use on the entire INL Site is restricted, and access to the INL Site and INTEC is controlled. Access to ICP and INL facilities requires proper clearance, training or an escort, and controls to limit exposures. Although 90 miles of public highways pass through the northern and southern portions of the INL Site, public access beyond the highway right-of-way is not allowed. Current and projected land uses are summarized below for the INL Site, surrounding lands, and INTEC.

\subsection{Land Use on and around the INL Site}

DOE administers land within the INL Site, and the Bureau of Land Management (BLM) (Department of Interior) administers livestock grazing leases within the undeveloped portion of the INL Site (Figure 6-1). The BLM classified the acreage within the INL Site (570,000 acres) as industrial and mixed use (DOE 1991). The current primary use of the INL Site is to support facility and program operations. Large tracts of land are reserved as buffer and safety zones along the boundary of the INL Site. Portions within the central area are reserved for ICP/INL operations. The remaining land within the core, which is largely undeveloped, is used for environmental research, ecological preservation, and sociocultural preservation. The buffer consists of $500 \mathrm{mi}^{2}$ of grazing land (DOE 1991) administered by the BLM.

In the counties surrounding the INL Site, approximately $45 \%$ of the land is used for agricultural production of livestock and crops, $45 \%$ is undeveloped, and 10\% is urban (DOE 1991). Most of the land surrounding the INL Site is owned by private individuals or the U.S. Government.

Future land use is addressed in the Long-Term Land Use Future Scenarios document (DOE-ID 1995) and the Infrastructure Long-Range Plan (INEEL 2001). Because future land-use scenarios are uncertain, assumptions were made in the Long-Term Land Use Future Scenarios document for defining factors such as development pressure, advances in research and technology, and ownership patterns. The following assumptions were applied to develop forecasts for land use within the INL Site:

- $\quad$ The INL Site will remain under DOE ownership and control until at least 2095. The boundary is currently static. INEEL (2003) indicates that the boundaries of the INL Site may shrink at some future date. Portions of the INL Site will be managed beyond 2095 due to DOE's responsibility for long-term stewardship.

- The life expectancy of current and new facilities is expected to range between 30 and 50 years. The decontamination and dismantlement process will commence following closure of each facility if new missions for the facility are not determined.

- $\quad$ No residential development (e.g., housing) will be allowed to occur within the current INL Site boundaries before 2095, and there are no specific reasons to expect such development after that date.

- $\quad$ No new major, private developments (residential or nonresidential) are expected in areas adjacent to the INL Site. 
Bureau of Land Management (grazing)

National Forest land

Private land (non-cultivated)

Private land (cultivated)

State land

INL buffer zone (grazing)

BLM land managed by DOE-ID

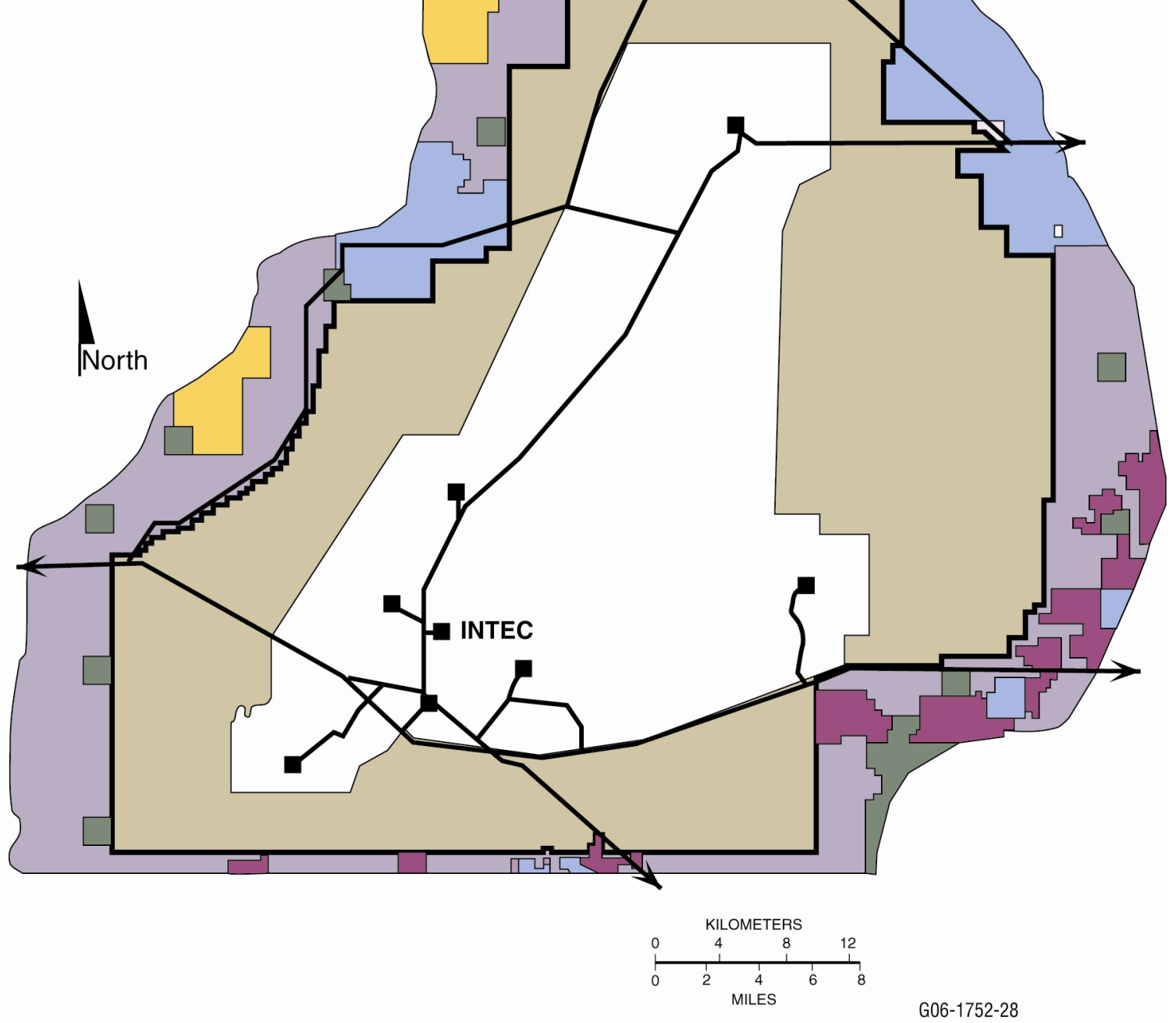

Figure 6-1. Land ownership and use in the vicinity of the Idaho National Laboratory Site. 
Future land use most likely will remain essentially the same as the current use: a research facility within the INL Site boundaries and agriculture and open land surrounding the INL Site. In addition, future land use will include the ICP/INL mission of nuclear energy research, development, and demonstration.

Laws and regulations that govern the transfer of federal land are presented in the INL Sitewide Institutional Controls Plan (DOE-ID 2006c). These will ensure future protection of human health and the environment through property transfer documentation required by CERCLA $\S 120$ (42 USC 9620) and EPA ICs policy, which include notices of contamination and remediation history, zoning restrictions issued by the appropriate local land use authority in conjunction with any transfer from federal ownership, restrictions in transfer deeds that preserve ICs, and warranties and covenants that all necessary remedial action has been performed prior to transfer of title and that the government will perform any additional remedial action found necessary after transfer. Because most INL Site land was withdrawn in 1949 from the BLM for the National Reactor Testing Station, the land that is no longer needed for the INL Site would be returned to the Public Domain under BLM management provided BLM agrees to accept responsibility for remaining CERCLA requirements related to such land. Some portions of the INL Site were acquired from previous nonfederal owners. Any transfer of land from federal to nonfederal ownership would require compliance with the detailed property transfer procedures of the Federal Property and Administrative Services Act (40 USC Subtitle I) and other applicable statutes, as well as the restrictions of CERCLA $\S 120(\mathrm{~h})$ (42 USC 9620). Due to the significant hurdles associated with transfer of federal land containing any residual contamination, including the potential liability of the federal government under CERCLA, tort, contract, and real property law, the transfer outside federal ownership, or even to unrestricted access under BLM management, would be highly unlikely for any such contaminated property at the INL Site. Therefore, the possibility of development of contaminated INL Site land by nonfederal entities, whether for residential or commercial purposes, is remote.

\subsection{Land Use at INTEC}

Current land use at INTEC is limited to industrial applications associated with (1) safe storage of SNF in preparation for shipment to a repository outside of Idaho, (2) technology development for safely treating high-level and liquid radioactive waste generated from previous fuel reprocessing activities, (3) remediation of past contamination releases to the environment, and (4) DD\&D of excess facilities. INTEC is a key part of implementing a 1995 Settlement Agreement (DOE 1995) whose key objectives are to remove all SNF from Idaho by 2035 and to prepare waste stored at the INL Site for removal from Idaho by the same date.

The Idaho High-Level Waste \& Facilities Disposition Final Environmental Impact Statement (HLW\&FD FEIS) (DOE 2002) discusses current land use plans that include a 100-year IC period for INTEC. For purposes of analysis, the year 2095 was selected as the end of DOE's ICs, which is consistent with the timeframe identified in the OU 3-13 ROD. INTEC has an established industrial infrastructure that includes grouted underground tanks and ancillary equipment at the TFF. The WCF, located to the southeast of the tank farm, has been closed with waste grouted in place to the standards applicable to a HWMA/RCRA landfill, including post-closure groundwater and cap monitoring. Future cleanup of other nearby facilities, such as the New Waste Calcining Facility, bin sets where calcined waste is stored, and Fuel Reprocessing Complex (see Buildings CPP-601, CPP-602, and CPP-630 on Figure 4-2) may leave waste in place. The Agencies have agreed that residential use over these facilities and grouted tanks is not a reasonable anticipated future use. The industrial use area is shown on Figure 4-2. 
In addition to limitations on future development imposed by anticipated physical characteristics, ICs will continue to be implemented at the INTEC facility for as long as land use or access restrictions are necessary to protect human health and the environment. The use of ICs has been established in the OU 3-13 ROD to prevent exposure to contaminated groundwater and soil until the risks reach acceptable levels.

\subsection{Groundwater Uses}

The SRPA is the source of all water used at the INL Site. INTEC withdraws raw water from production wells located in the northwestern corner of INTEC for industrial uses such as process water and fire water. Potable water for workers comes from two production wells located northeast of INTEC and meets MCLs. The portion of the SRPA that exceeds MCLs from INTEC sources is not currently used. Residential use of the SRPA on the INL Site cannot occur before 2095 and is only a remote possibility after that time. For purposes of designing the OU 3-14 remedial action, it is assumed that hypothetical future residents could live outside the INTEC industrial use area and use the SRPA as a drinking water source in 2095 and beyond. 


\section{SITE RISKS}

The BRA estimates what risks the site would pose if no action were taken and no administrative controls were in place to protect workers. It provides the basis for taking action and identifies the contaminants and exposure pathways that need to be addressed by the remedial action. This section of the ROD summarizes the results of the BRA, which was presented in detail in DOE-NE-ID (2006a) Sections 6, 7, and 8 .

\subsection{Summary of Human Health Risk Assessment}

The conceptual site model (Figure 7-1) identifies the primary and secondary contaminant sources and release mechanisms, exposure pathways, exposure routes, and classes of receptors specific to the OU 3-14 risk assessment. Two primary sources exist: the tank farm system and the former injection well. Leaks and spills, primarily from the tank farm piping and valves, resulted in contamination of soil, perched water, and the SRPA. Human exposures to contaminants can occur primarily by direct contact with surface soil at the release sites (for workers) or, in the future, through ingestion of contaminated SRPA groundwater (for future residents). A potentially complete exposure pathway/route for a receptor means that the source, release mechanism, pathway, and exposure route are possible from contaminants at the tank farm. An incomplete exposure pathway indicates that one or more criteria (i.e., pathway, exposure route, or receptor) do not exist or have limited exposure. The model indicates incomplete exposure routes for current workers because workers infrequently visit the tank farm. Visits are under controlled access conditions and workers do not remain there for long periods of time. The Agencies agree that significant exposure for current workers is not likely, due to administrative controls that currently exist on the tank farm. However, the Agencies evaluated a current worker scenario in the OU 3-14 RI/BRA to facilitate remedial action decision-making. The Agencies agree that future residential use of the industrial use area of INTEC is also not a reasonable scenario. Because all OU 3-14 soil sites are located in the industrial use area, residential contact with soil was considered an incomplete pathway and not assessed in the OU 3-14 RI/BRA. Future residents could live outside the industrial use area and could be exposed to contaminated groundwater. To be conservative, the Agencies used the maximum predicted groundwater concentration in 2095 and beyond for the risk assessment regardless of whether the peak occurred inside or outside the industrial use area. The Agencies did not assess potential future ingestion of contaminated SRPA groundwater by workers because the residential exposure scenario is more conservative.

The primary potential exposure route is from radionuclide-contaminated soil inside the tank farm boundary (direct exposure by workers) and ingestion, by hypothetical future residents, of contaminated groundwater from beneath southern INTEC.

\subsubsection{Soil}

A risk assessment for exposure to contaminated soil was conducted using the risk assessment previously completed under OU 3-13 (DOE-ID 1997a). In general, CERCLA risk assessments for workers at the INL Site use a maximum depth of $4 \mathrm{ft}$ for surface pathways based on an assumption that workers would dig only to the depth necessary to complete building foundations below the frost line. Risks from the other surface exposure routes calculated in the OU 3-13 RI/BRA-inhalation of volatiles and particulates, incidental ingestion of surface soil, and dermal absorption, which are calculated from contaminant concentrations in the top 6 in. of soil-were calculated to be at far less than $1 \times 10^{-6}$ excess cancer risk (highest was $1 \times 10^{-9}$ ) and hazard quotient of 1 , cumulatively, for the tank farm. This was expected as most of the tank farm sites had releases that occurred below the 6-in. soil depth, making the depth of 0 to $4 \mathrm{ft}$ (direct gamma exposure) and deeper (groundwater) the only exposure pathways of concern. 


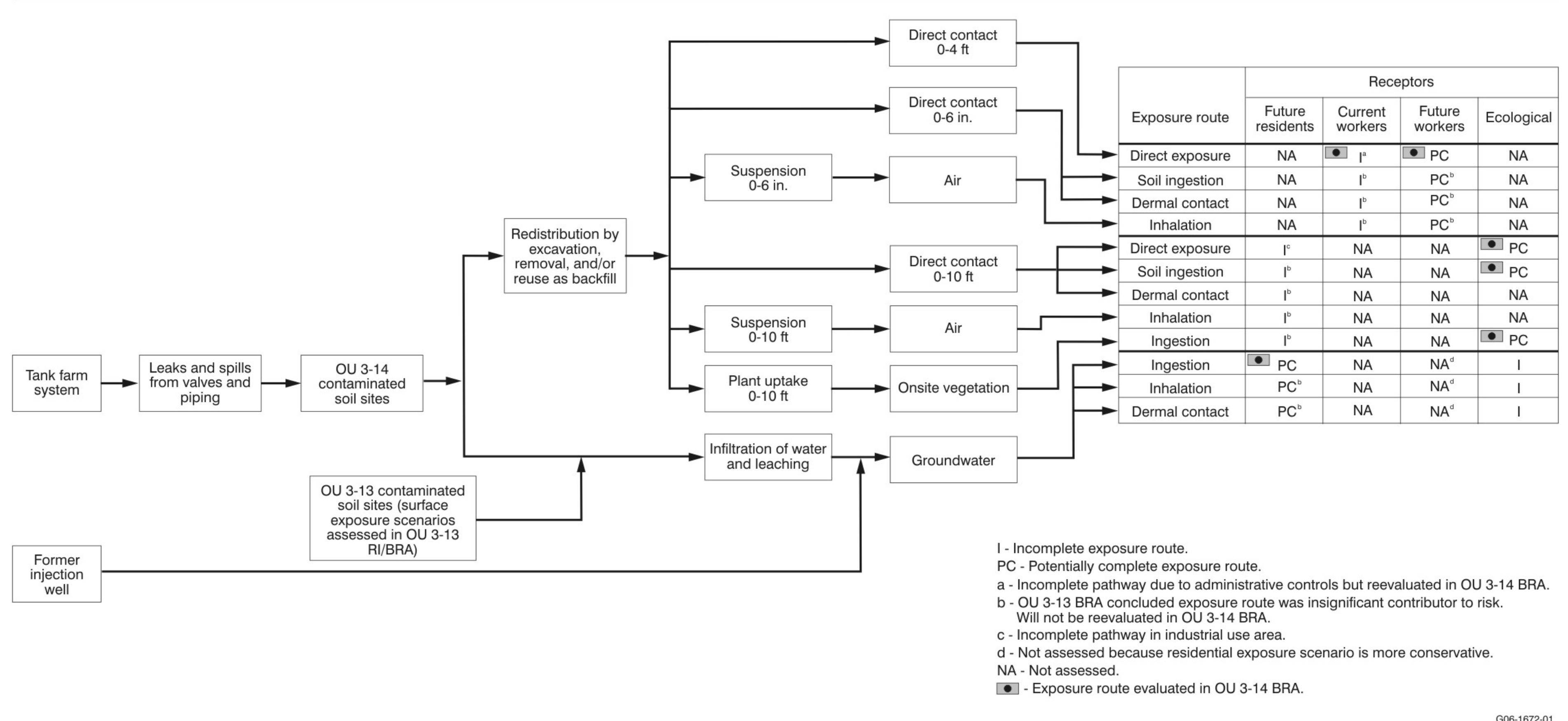

Figure 7-1. OU 3-14 conceptual site model showing groundwater source term, OU 3-14 and OU 3-13 contributing sources, release mechanisms, exposure pathways, and exposure routes and receptors for the OU 3-14 risk assessment. 
In addition, the OU 3-13 RI/BRA (DOE-ID 1997a, Tables 10-13 and 10-15) demonstrated that there are no noncarcinogenic hazards to the worker from nonradiological contaminants. To confirm this, all new nonradiological sampling data from 0 to 10 -ft depth bgs (mostly not detected) were screened for risk/hazard using EPA Region 9 preliminary remediation goals (PRGs) (EPA 2006a). All nonradiological contaminants were eliminated from further consideration during this screening step (see Appendix I of DOE-NE-ID 2006a) and, therefore, were not evaluated further in the risk assessment.

Because of the mixing of surface soil during tank farm excavation projects, all sampling data, including historical data, for inside the tank farm boundary were pooled for evaluation of surface soil risk. Soil inside the tank farm boundary includes Sites CPP-16, CPP-20, CPP-24, CPP-25, CPP-26, CPP-27/33, CPP-28, CPP-30, CPP-31, CPP-32E, CPP-32W, CPP-58W, CPP-79 (shallow), CPP-79 (deep), CPP-112, and contaminated soil used as backfill in the tank farm.

Grouping sites within the tank farm boundary is reasonable because it is improbable that a worker would remain over any single site for the duration of the exposure scenario (which is assumed to be 40 hours per week, 50 weeks per year, for 25 years). The risk assessment for the other two sites, CPP-15 and CPP-58, which are outside the tank farm, was conducted separately for each site because these two sites are not contiguous and the contaminant sources were different.

Contaminants of potential concern, exposure assessment, and toxicity assessment are presented in Section 7.2 of DOE-NE-ID (2006a). EPA classifies all radionuclides as known human cancer-causing agents (Group A carcinogens), based on their property of emitting ionizing radiation and on the extensive weight of evidence provided by epidemiological studies of radiogenic cancers in humans. At Superfund radiation sites, EPA generally evaluates potential human health risks based on the radiotoxicity, i.e., adverse health effects caused by ionizing radiation, rather than on the chemical toxicity of each radionuclide present. These evaluations consider the carcinogenic effects of radionuclides only. In most cases, cancer risks are limiting, exceeding both mutagenic and teratogenic risks. For the OU 3-14 $\mathrm{RI} / \mathrm{BRA}$, radionuclide slope factors for converting external exposure to lifetime risk of cancer incidence are taken from EPA's Health Effects Assessment Summary Tables (HEAST) - Radionuclides Table (EPA 2006b), formerly HEAST Table 4. HEAST slope factors used in the OU 3-14 RI/BRA for external exposure are shown on Table 7-3 of the RI/BRA (DOE-NE-ID 2006a).

All radionuclides detected at greater-than-detection limits were evaluated for risk in the OU 3-14 RI/BRA. Screening performed for nonradiological contaminants indicated that these contaminants (mostly not detected) would not significantly contribute to risk (see Appendix I of the RI/BRA). EPA recommends that the exposure point concentration used to calculate risk at a site represents a reasonable estimate of the average concentration likely to be contacted over time. EPA guidance also states that because of the uncertainty associated with estimating the true average concentration at a site, the $95 \%$ upper confidence limit (UCL) for the arithmetic mean should be used for this variable (EPA 1992). The exposure point concentration used in the risk assessment is the 95\% UCL for the mean or the maximum concentration, whichever is less.

Risk characterization combines the results of the exposure and toxicity assessments to quantify the health risk. For carcinogens such as the radionuclides detected at OU 3-14 sites, risks are generally expressed as the incremental probability of an individual developing cancer over a lifetime as a result of exposure to the carcinogen. Excess lifetime cancer risk is calculated from Equation 7-1:

Risk $=$ Exposure $\times$ CSF 
where

$$
\begin{array}{ll}
\text { Risk } & =\text { potential lifetime excess cancer risk (unitless) for a contaminant } \\
\text { Exposure } & =\text { direct radiation exposure }(\mathrm{yr}-\mathrm{pCi} / \mathrm{g}) \\
\mathrm{CSF} & =\text { contaminant external exposure slope factor }(\text { risk } / \mathrm{yr} \text { per } \mathrm{pCi} / \mathrm{g}) .
\end{array}
$$

The total cancer risk from all contaminants is calculated by summing the calculated risks for all radionuclides considered in the risk assessment. The total risk from all exposure routes from soil was calculated by adding the inhalation and ingestion risks calculated in the OU 3-13 RI/BRA (DOE-ID 1997a) to the direct exposure risks calculated in the OU 3-14 RI/BRA. Because the risks from all other contaminants and all other pathways were low, direct exposure to Cs-137 dominates the risk profile.

The generally acceptable risk range for site-related exposures under the NCP (40 CFR 300) is $10^{-4}$ to $10^{-6}$. The Agencies agree that acceptable risk for OU 3-14 is at the upper end of this range $\left(1 \times 10^{-4}\right)$ based on (1) the conservative nature of the risk assessment, e.g., it is unlikely there will be future industrial re-use of the OU 3-14 soil sites; therefore, worker exposure is anticipated to be much less than 40 hours per week for 25 years; (2) use of the $1 \times 10^{-4}$ risk-based level in the OU 3-13 ROD for all CERCLA soil sites at INTEC (which surround OU 3-14); and (3) the isolation of the INL Site.

Table 7-1 presents the risk for the current worker scenario for soil inside the tank farm boundary. The total current worker risk, $2 \times 10^{-2}$, is due to external radiation (direct exposure) from Cs-137. Eu-154 contributes about $0.1 \%$ to the total current worker risk, with the remaining radionuclides and exposure routes (ingestion of soil, inhalation) making an insignificant contribution. This same conclusion, that total worker risk is solely due to external radiation from Cs-137, holds true for all other potentially complete

\begin{tabular}{|c|c|c|c|c|c|}
\hline $\begin{array}{c}\text { Contaminant } \\
\text { of Potential } \\
\text { Concern }\end{array}$ & $\begin{array}{c}\text { Concentration } \\
(\mathrm{pCi} / \mathrm{g})^{\mathrm{a}}\end{array}$ & $\begin{array}{c}\text { Average } \\
\text { Concentration over } \\
\text { Exposure Duration }^{\mathrm{b}} \\
(\mathrm{pCi} / \mathrm{g})\end{array}$ & $\begin{array}{c}\text { Direct } \\
\text { Radiation } \\
\text { Exposure } \\
\text { (pCi-yr } / \mathrm{g})\end{array}$ & $\begin{array}{c}\text { Direct } \\
\text { Radiation Risk }\end{array}$ & $\begin{array}{l}\text { Other Exposure } \\
\text { Route Risk }\end{array}$ \\
\hline Am-241 & 1.02 & 1.00 & 5.72 & $1.6 \mathrm{E}-07$ & $-^{\mathrm{d}}$ \\
\hline Сo-60 & 0.027 & 0.0079 & 0.045 & $5.6 \mathrm{E}-07$ & - \\
\hline Cs-134 & 0.009 & 0.001 & 0.006 & 4.1E-08 & - \\
\hline Cs-137 & 1,848 & 1,405 & 8,008 & $2.0 \mathrm{E}-02$ & $5.0 \mathrm{E}-08$ \\
\hline Eu-154 & 1.52 & 0.664 & 3.79 & $2.2 \mathrm{E}-05$ & - \\
\hline $\mathrm{Np}-237$ & 0.15 & 0.15 & 0.85 & $6.8 \mathrm{E}-07$ & - \\
\hline $\mathrm{Pu}-238$ & 3.17 & 2.88 & 16.4 & $4.5 \mathrm{E}-07$ & - \\
\hline $\mathrm{Pu}-239$ & 0.61 & 0.61 & 3.5 & $6.9 \mathrm{E}-10$ & - \\
\hline Sr-90 & 89 & 67 & 380 & $1.8 \mathrm{E}-07$ & $2.0 \mathrm{E}-08$ \\
\hline Tc-99 & 2.01 & 2.01 & 11.5 & $9.3 \mathrm{E}-10$ & - \\
\hline $\mathrm{U}-234$ & 1.08 & 1.08 & 6.2 & $1.6 \mathrm{E}-09$ & - \\
\hline $\mathrm{U}-235$ & 0.075 & 0.075 & 0.43 & $2.3 \mathrm{E}-07$ & - \\
\hline $\mathrm{U}-238$ & $\mathrm{e}$ & e & e & $\mathrm{e}$ & $\mathrm{e}$ \\
\hline Total & N/A & N/A & N/A & 2E-02 & 7E-08 \\
\hline \multicolumn{6}{|c|}{$\begin{array}{l}\text { a. } 95 \% \text { UCL or maximum of the } 0 \text { to } 4 \text {-ft sampling data decayed t } \\
\text { b. } 25 \text {-year average of the integrated concentration (with decay) ov } \\
\text { c. Sum of risks from soil ingestion and inhalation taken from both } \\
\text { RI/BRA (DOE-ID 1997a). } \\
\text { d. - indicates no data available and not calculated in OU 3-13. } \\
\text { e. Less than background (see Table } 7-4 \text { of DOE-NE-ID 2006a). } \\
\text { N/A = not applicable. }\end{array}$} \\
\hline
\end{tabular}
soil pathways in OU 3-14 (see Tables 7-10 through 7-14 in the OU 3-14 RI/BRA).

Table 7-1. Current worker scenario risk assessment results for soil inside the tank farm boundary. 
The results of the soil risk assessment are summarized in Table 7-2. These risk estimates are based on a reasonable maximum exposure and were developed by taking into account various conservative assumptions about the frequency and duration of a worker's exposure to soil, as well as the toxicity of Cs-137. The total risk from direct exposure to contaminated soil inside the tank farm boundary for a current unprotected worker is estimated to be $2 \times 10^{-2}$ and for a future unprotected worker is $3 \times 10^{-3}$. These risk levels indicate that if no cleanup action is taken, a current worker would have an increased probability of 2 in 100 of developing cancer as a result of site-related exposure to Cs-137 and a future worker would have an increased probability of 3 in 1,000. These risk results exceed the risk criteria of $1 \times 10^{-4}$ established in the OU 3-13 ROD (DOE-ID 1999a). The total risk to a current worker from direct exposure to contaminated soil is estimated to be $7 \times 10^{-4}$ at Site CPP-15 and $4 \times 10^{-4}$ at Site CPP-58. Due to radioactive decay (Cs-137 has a 30-year half life), these risks drop to acceptable levels, i.e., below $1 \times 10^{-4}$, before $2095\left(8 \times 10^{-5}\right.$ for Site CPP-15 and $5 \times 10^{-5}$ for CPP-58). No other metals, chemicals, or radionuclides other than Cs-137 pose an unacceptable risk or hazard to human health or the environment through the surface pathway.

Table 7-2. Estimated total risk $^{\mathrm{a}}$ to an unprotected worker from contaminated surface soil.

\begin{tabular}{|c|c|c|c|c|}
\hline Site & Contaminant & $\begin{array}{l}\text { Risk to Current Worker } \\
(2005)^{\mathrm{b}}\end{array}$ & $\begin{array}{l}\text { Risk to Future Worker } \\
(2095)^{\mathrm{b}}\end{array}$ & $\begin{array}{c}\text { Primary Exposure } \\
\text { Pathway } \\
\end{array}$ \\
\hline $\begin{array}{l}\text { Soil inside tank } \\
\text { farm boundary }\end{array}$ & Cs-137 & $2 \mathrm{E}-02(200$ in 10,000$)$ & $3 E-03(30$ in 10,000$)$ & External exposure \\
\hline CPP-15 & Cs-137 & $7 \mathrm{E}-04(7$ in 10,000$)$ & $8 \mathrm{E}-05(0.8$ in 10,000$)$ & External exposure \\
\hline CPP-58 & Cs-137 & $4 \mathrm{E}-04(4$ in 10,000$)$ & $5 \mathrm{E}-05(0.5$ in 10,000$)$ & External exposure \\
\hline $\begin{array}{l}\text { Bold }=\text { Risks that ex } \\
\text { a. Cs-137 risk via ex } \\
\text { therefore equivalent } \\
\text { b. No contaminants }\end{array}$ & $\begin{array}{l}\text { eptable levels (1E- } \\
\text { posure alone excee } \\
\text { isk. } \\
\text { n Cs-137 present in }\end{array}$ & $\begin{array}{l}\text { isk-based level). } \\
\text { isks for all other pathways at } \\
\text { soil pose an unacceptable ri }\end{array}$ & $\begin{array}{l}\text { DCs combined by over two } \\
\text { hazard to human health or } t\end{array}$ & $\begin{array}{l}\text { ers of magnitude and is } \\
\text { environment. }\end{array}$ \\
\hline
\end{tabular}

\subsubsection{Groundwater}

The groundwater in the SRPA currently exceeds safe drinking water standards for Tc-99, Sr-90, I-129, and nitrate as nitrogen. The model predicts that the maximum concentrations of all contaminants in the aquifer reached their peak prior to 2000, are trending downward, and will continue to decline over time. Sr-90 is the only contaminant that is predicted to exceed federal MCLs in 2095 and beyond if no further remedial action is taken to protect groundwater. Risks from ingesting contaminated groundwater were assessed assuming a resident consumes 2 L per day for 30 years. Table 7-3 summarizes the results of the groundwater risk assessment and includes the MCL, maximum SRPA concentration measured in 2005, predicted concentrations in 2005 and 2095, risk to future residents in 2095, and the year the concentration is predicted to be below the MCL. Although Sr-90 was the only contaminant predicted to exceed MCLs beyond 2095, all contaminants that were considered in the groundwater risk assessment are shown because the potential additive effect increases the overall risk from $2 \times 10^{-5}$ for Sr-90 to $3 \times 10^{-5}$ for all groundwater contaminants. The model also predicts that the residual $\mathrm{Sr}-90$ remaining in the tank farm soil is relatively immobile (due to ion exchange) and is an insignificant contributor to overall risk to the aquifer (see Appendix J of DOE-NE-ID 2006a). The risk to the aquifer is from remobilization of the Sr-90 that initially moved quickly out of the alluvium, is reversibly sorbed onto the interbed sediments and basalts, and can be carried down to the aquifer through perched water. 
Table 7-3. Human health contaminants of concern summary (groundwater ingestion pathway) for all INTEC CERCLA sources (if no action taken).

\begin{tabular}{|c|c|c|c|c|c|c|c|c|}
\hline Contaminant & MCL & $\begin{array}{c}\text { Year of } \\
\text { Simulated } \\
\text { SRPA Peak } \\
\text { Concentration } \\
\end{array}$ & $\begin{array}{c}\text { Actual Maximum } \\
\text { Concentration } \\
(2005)\end{array}$ & $\begin{array}{c}\text { Predicted } \\
\text { Concentration } \\
(2005) \\
\end{array}$ & $\begin{array}{c}\text { Predicted } \\
\text { Maximum } \\
\text { Concentration } \\
(2095) \\
\end{array}$ & $\begin{array}{c}\text { Estimated Risk to } \\
\text { Future Resident } \\
(2095) \\
\end{array}$ & $\begin{array}{c}\text { Year Predicted to be } \\
\text { below Safe Drinking } \\
\text { Water Standard }\end{array}$ & $\begin{array}{l}\text { Aquifer Model } \\
\text { Termination } \\
\text { Date } \\
\end{array}$ \\
\hline $\mathrm{H}-3$ & $20,000 \mathrm{pCi} / \mathrm{L}$ & 1965 & $8,740 \pm 207 \mathrm{pCi} / \mathrm{L}$ & $9,970 \mathrm{pCi} / \mathrm{L}^{\mathrm{a}}$ & $123 \mathrm{pCi} / \mathrm{L}$ & $1 \mathrm{E}-07$ & 2001 & 2095 \\
\hline Sr-90 & $8 \mathrm{pCi} / \mathrm{L}$ & 1965 & $35.3 \pm 0.8 \mathrm{pCi} / \mathrm{L}$ & $40.8 \mathrm{pCi} / \mathrm{L}$ & $18.6 \mathrm{pCi} / \mathrm{L}$ & $2 \mathrm{E}-05$ & 2129 & 2293 \\
\hline Tc-99 & $900 \mathrm{pCi} / \mathrm{L}^{\mathrm{b}}$ & 1999 & $2,900 \pm 47 \mathrm{pCi} / \mathrm{L}$ & $235 \mathrm{pCi} / \mathrm{L}$ & $9.8 \mathrm{pCi} / \mathrm{L}$ & $6 \mathrm{E}-07$ & 1999 & 2095 \\
\hline I-129 & $1 \mathrm{pCi} / \mathrm{L}^{\mathrm{b}}$ & 1970 & $1.2 \pm 0.1 \mathrm{pCi} / \mathrm{L}$ & $3.9 \mathrm{pCi} / \mathrm{L}$ & $0.9 \mathrm{pCi} / \mathrm{L}$ & $3 \mathrm{E}-06$ & 2080 & 2095 \\
\hline $\mathrm{Np}-237$ & $15 \mathrm{pCi} / \mathrm{L}$ & 1965 & ND & $4.1 \mathrm{pCi} / \mathrm{L}$ & $4.2 \mathrm{pCi} / \mathrm{L}$ & $5 \mathrm{E}-06$ & 1987 & 2304 \\
\hline $\mathrm{Pu}-239$ & $15 \mathrm{pCi} / \mathrm{L}$ & 1960 & ND & $0.02 \mathrm{pCi} / \mathrm{L}$ & $0.002 \mathrm{pCi} / \mathrm{L}$ & $3 \mathrm{E}-09$ & Always & $\begin{array}{l}2095 \text { (vadose } \\
\text { zone modeled to } \\
\text { year } 87,594)\end{array}$ \\
\hline $\mathrm{Pu}-240$ & $15 \mathrm{pCi} / \mathrm{L}$ & 1960 & ND & $0.009 \mathrm{pCi} / \mathrm{L}$ & $0.001 \mathrm{pCi} / \mathrm{L}$ & $3 \mathrm{E}-09$ & Always & $\begin{array}{l}2095 \text { (vadose } \\
\text { zone modeled to } \\
\text { year } 87,594)\end{array}$ \\
\hline U-234 & $30 \mu \mathrm{g} / \mathrm{L}$ & 1958 & $2.5 \pm 0.2 \mu \mathrm{g} / \mathrm{L}$ & $1.2 \mathrm{E}-04 \mu \mathrm{g} / \mathrm{L}^{\mathrm{c}}$ & $2 \mathrm{E}-04 \mu \mathrm{g} / \mathrm{L}$ & $2 \mathrm{E}-06$ & Always & 2304 \\
\hline Total risk & & & & & & $3 \mathrm{E}-05$ & & \\
\hline $\mathrm{Hg}$ & $2 \mu \mathrm{g} / \mathrm{L}$ & 1981 & $0.08 \mu \mathrm{g} / \mathrm{L}$ & $0.6 \mu \mathrm{g} / \mathrm{L}$ & $0.3 \mu \mathrm{g} / \mathrm{L}^{\mathrm{d}}$ & $\begin{array}{c}0.01 \\
\text { (hazard quotient) }\end{array}$ & 1993 & 4587 \\
\hline $\mathrm{NO}_{3}-\mathrm{N}$ & $10 \mathrm{mg} / \mathrm{L}$ & 1993 & $13.2 \mathrm{mg} / \mathrm{L}$ & $6.2 \mathrm{mg} / \mathrm{L}$ & $2.1 \mathrm{mg} / \mathrm{L}$ & $\begin{array}{c}0.04 \\
\text { (hazard quotient) }\end{array}$ & 1998 & 2095 \\
\hline Total hazard $\mathrm{i}$ & & & & & & 0.05 & & \\
\hline $\begin{array}{l}\text { Bold = Informati } \\
\mathrm{ND}=\text { Not detecte } \\
\text { a. This prediction } \\
\text { b. Derived MCL. } \\
\text { c. The predicted } \mathrm{I} \\
\text { d. This prediction }\end{array}$ & $\begin{array}{l}n \text { contaminants that } \\
\text { entered into RI/BR } \\
4 \text { concentration fluc } \\
\text { entered into RI/BR }\end{array}$ & $\begin{array}{l}\text { ently or are predictec } \\
\text { ables 8-3 and A-9-12 } \\
\text { es over time (2095 p } \\
\text { ables 8-3, 8-4, and A }\end{array}$ & $\begin{array}{l}\text { xceed their MCLs. } \\
\text { orrectly as } 99,700 \mathrm{pCi} / \mathrm{L} \\
\text { tion exceeds the } 2005 \mathrm{pr} \\
2 \text { incorrectly as } 0.13 \mu \mathrm{g} / \mathrm{l}\end{array}$ & $\begin{array}{l}\text { lave been } 9,970 \\
\text { but never excee } \\
\text { l have been } 0.3\end{array}$ & $\begin{array}{l}8 \text { predicted pe } \\
\text { displayed cor }\end{array}$ & $\begin{array}{l}\text { Figure A-9-7. } \\
\text { (5.4E-04 } \mu \mathrm{g} / \mathrm{L}) \text {. } \\
\text { Figure A-9-43. }\end{array}$ & & \\
\hline
\end{tabular}


There is uncertainty in the estimate of risks from future ingestion of groundwater because of the reliance on modeling to predict future concentrations. The modeling predictions of future concentrations have uncertainty corresponding to possible ranges in some of the input values. The inputs were set at realistic and, in some cases, conservative, values. The uncertainty analysis is presented in the RI/BRA (DOE-NE-ID 2006a). For parameters that had some uncertainty in the input values, sensitivity runs were performed at the extreme ends of the range of values to further assess uncertainty.

The model underpredicts the current Tc-99 maximum concentration by a factor of 12 and underpredicts the peak concentration by an estimated factor of 3 (modeled concentrations peaked in 1999 at $935 \mathrm{pCi} / \mathrm{L})$. Despite this uncertainty, it is likely that the Tc-99 concentrations will be well below the MCL by 2095, in part because the predicted 2095 concentration $(9.8 \mathrm{pCi} / \mathrm{L})$ is so far below the MCL (by a factor of 90).

\subsection{Cumulative Risk}

The baseline risk results have been presented separately for the soil and groundwater pathways. The cumulative risk for the surface pathways, across all COCs, is dominated by the risk from the external exposure to Cs-137 because this risk is so much greater than the other risks. There is no groundwater pathway associated with the current occupational exposures because the water supply wells currently in use at INTEC are located upgradient of the facility. Therefore, there is no possibility that a current worker would be exposed through both the surface and groundwater pathways and thus the cumulative risk is represented by the risk presented in Table 7-2.

A future resident could hypothetically reside outside the industrial use area and would not be exposed to contaminated soil in the industrial use area. The cumulative risk for a future resident is the total risk from the groundwater pathway, $3 \times 10^{-5}$, and the hazard index (HI) is 0.05 (see Table 7-3). This is a conservative estimate because the maximum groundwater concentrations for each contaminant do not overlap in space and time.

A future worker inside the industrial use area could be exposed to both contaminated soil and contaminated groundwater. The risk from drinking contaminated groundwater would be less than the residential exposure of $3 \times 10^{-5}$ because workers are assumed to ingest less water than a resident. Because the risk to a future worker inside the tank farm boundary from ingestion of groundwater would be several orders of magnitude less than the risk from external exposure to soil, the cumulative risk for all pathways is not greater than the risk through the external exposure pathway.

For a future worker in the year 2095 and beyond at Sites CPP-15 or CPP-58, which are located outside the tank farm boundary, the Cs-137 concentration in the soil will have decayed to acceptable levels. However, groundwater is predicted to exceed the MCL for Sr-90 until 2129 if no action is taken.

\subsection{Cumulative Impacts from Non-CERCLA Residual Sources at INTEC}

Cumulative impacts from non-CERCLA residual sources at INTEC such as the WCF, which has been grouted in place, and the residuals that could be left in place when the tanks, sand pads, and associated piping in the TFF are closed are addressed in Section 1.3.12 of the OU 3-14 FS (DOE-ID 2006d). This assessment was done to ensure that cumulative risks from remediated CERCLA and non-CERCLA sources do not exceed risk-based levels. Releases associated with non-CERCLA INTEC sources were determined to occur at different times than the baseline risks for the CERCLA INTEC sources - the peaks did not overlap — and the peak risks from conservative estimates of these 
sources post-closure will be so low that the cumulative risk will not exceed risk-based levels or MCLs. The cumulative risk assessment showed that no concern exists over the cumulative effects between the closed TFF, WCF, and the tank farm soil.

\subsection{Ecological Risk Assessment}

The ecological risk assessment (ERA) performed for OU 3-13 was updated to incorporate new data (see Chapter 7 of the RI/BRA, DOE-NE-ID 2006a). An ERA had previously been performed in the OU 3-13 RI/FS and presented in Section 28 of DOE-ID (1997b). The OU 3-13 ERA follows the approach presented in the Guidance Manual for Conducting Screening Level Ecological Risk Assessments at the INEL (VanHorn, Hampton, and Morris 1995) and uses the 0 to $10-\mathrm{ft}$ depth for evaluation, similar to the risk assessments for the residential intrusional scenario. The results of this assessment found that several metals and radionuclides are potentially at levels of concern. Because of the availability of new sampling data for OU 3-14 and updated input parameters for ecological receptors available from EPA (EPA 2006c) and the OU 10-04 Comprehensive RI/FS (DOE-ID 2001), these data were reassessed under OU 3-14 to ensure that the conclusions made in the OU 3-13 RI/FS are still valid.

\subsubsection{Ecological Risk Assessment Results}

Initial screening of contaminants was performed as discussed in Sections 7.4 and 7.5 of the RI/BRA (DOE-NE-ID 2006a). Both CPP-15 and soil inside the tank farm boundary had contaminants at concentrations above screening levels. Hazard quotients and hazard indexes were calculated for both nonradionuclides and radionuclides (both for external and internal exposure) using the approach documented in the OU 10-04 Comprehensive RI/FS (DOE-ID 2001). Changes based on the new or updated chemical-specific documents from EPA (EPA 2006d) were included for antimony, arsenic, barium, beryllium, cadmium, chromium (no value is available for exposure to plants), cobalt, lead, and vanadium. A hazard quotient is developed by dividing the maximum dose from the contaminant by its toxicity value. An HI is developed by summing hazard quotients for each contaminant by species. At the INL Site, it is accepted that, if the total HI does not exceed 10, then the contaminants remaining can be eliminated for risk to ecological receptors at the population level.

For CPP-15, none of the HIs exceeded 10 for any of the species evaluated (see Tables 7-16 and 7-17 of the OU 3-14 RI/BRA, DOE-NE-ID 2006a).

For soil inside tank farm boundary, none of the HIs exceeded 1 for chromium (see Tables 7-18 and 7-19 in the RI/BRA). There is a significant risk (with HIs over 400) from internal exposure to radionuclides at this site (see Table 7-4); however, the external exposure is at acceptable levels (the highest HI is 4.0 as shown on Tables 7-22 and 7-23 of the RI/BRA, DOE-NE-ID 2006a).

\subsubsection{Summary of Results for the Ecological Risk Assessment}

The ERA concluded that a potential exists inside the tank farm for biotic receptors to receive unacceptable internal exposure to the individual contaminants Cs-137 and Sr-90. The ERA used the conservative assumptions that the habitat in the area was freely available for use by ecological receptors and that the maximum concentration of the contamination in the 0 to $10-\mathrm{ft}$ range was available to all receptors. In reality, the surface of the tank farm is covered with an impermeable membrane, gravel, asphalt, or structures, which inhibit plant growth and discourage use by animals in the area. A more detailed assessment that takes these facts into account would result in a reduced calculated risk. 
Table 7-4. Hazard quotients for internal exposure of ecological receptors to radionuclides from soil inside the tank farm boundary.

\begin{tabular}{|c|c|c|c|}
\hline Functional Groups & $\begin{array}{l}\text { Hazard Quotient } \\
\text { for Cs-137 } \\
\text { (unitless) }\end{array}$ & $\begin{array}{l}\text { Hazard Quotient } \\
\text { for Sr-90 } \\
\text { (unitless) }\end{array}$ & Hazard Index \\
\hline Avian herbivores (AV121) & 2.E+01 & $8 . E+01$ & $1 . \mathrm{E}+02^{\mathrm{c}}$ \\
\hline Avian herbivores (AV122) & 9. $\mathrm{E}+01$ & $3 . \mathrm{E}+02$ & 4.E+02 \\
\hline Avian insectivores (AV210) & 6.E+01 & 2. $\mathrm{E}+02$ & 3.E+02 \\
\hline Black tern & 2. $\mathrm{E}+01$ & 8.E+01 & 1.E+02 \\
\hline Avian insectivores (AV210A) & 6. $\mathrm{E}+01$ & 2. $\mathrm{E}+02$ & 3.E+02 \\
\hline Avian insectivores (AV221) & 6.E+01 & 2. $\mathrm{E}+02$ & 3.E+02 \\
\hline Avian insectivores (AV222) & 9. $\mathrm{E}+01$ & 3.E+02 & 4.E+02 \\
\hline Avian insectivores (AV222A) & 6.E+01 & 2. $\mathrm{E}+02$ & 3.E+02 \\
\hline Great Basin spadefoot toad & 9. $\mathrm{E}+01$ & 3.E+02 & 4.E +02 \\
\hline Mourning dove & $9 . \mathrm{E}+01$ & $3 . \mathrm{E}+02$ & 4.E+02 \\
\hline Sage sparrow & 6.E+01 & 2. $\mathrm{E}+02$ & 3.E+02 \\
\hline Ferruginous hawk & 6.E+01 & 2. $\mathrm{E}+02$ & 3.E+02 \\
\hline Loggerhead shrike & 6. $\mathrm{E}+01$ & 2. $E+02$ & 3.E+02 \\
\hline Burrowing owl & 2.E+01 & $8 . \mathrm{E}+01$ & 1.E+02 \\
\hline Black-billed magpie & 9. $\mathrm{E}+01$ & $3 . \mathrm{E}+02$ & 4.E+02 \\
\hline Mule deer & 9. $\mathrm{E}+01$ & 2. $\mathrm{E}+02$ & 3.E+02 \\
\hline Pygmy rabbit & 9.E+01 & 2.E+02 & 3.E+02 \\
\hline Townsend's western big-eared bat & 9. $\mathrm{E}+01$ & 2. $\mathrm{E}+02$ & 3.E+02 \\
\hline Coyote & 9. $\mathrm{E}+01$ & 2.E+02 & 3.E+02 \\
\hline Deer mouse & 9. $\mathrm{E}+01$ & 2. $\mathrm{E}+02$ & 3.E+02 \\
\hline Sagebrush lizard & 9. $\mathrm{E}+01$ & $3 . E+02$ & 4. $\mathrm{E}+02$ \\
\hline Plants & 9. $\mathrm{E}+00$ & 3.E +01 & 4.E+01 \\
\hline Grasshoppers, beetles & $9 . \mathrm{E}+01$ & 4.E+03 & 4.E+03 \\
\hline $\begin{array}{l}\text { a. Maximum concentration for Cs-137 is } 5 \text {. } \\
\text { b. Maximum concentration for Sr-90 is } 3.2 \\
\text { c. Bold indicates HI above } 10 \text {. }\end{array}$ & & & \\
\hline
\end{tabular}

\subsection{Basis for Action}

The Agencies determined that soil inside the tank farm boundary poses an unacceptable risk due to the high levels of Cs-137 contamination and the significant risk from direct radiation to human health and the environment should exposures occur $\left(2 \times 10^{-2}\right.$ to current worker and $3 \times 10^{-3}$ to future worker from Cs-137). The Agencies determined that soil at Sites CPP-15 and CPP-58, which are located outside the tank farm boundary, poses an unacceptable risk to the current worker due to Cs-137 contamination $\left(7 \times 10^{-4}\right.$ and $4 \times 10^{-4}$ for Sites CPP-15 and CPP-58, respectively), but risks to a future worker are acceptable $\left(8 \times 10^{-5}\right.$ and $\left.5 \times 10^{-5}\right)$, if direct exposure were to occur. Concentrations in the groundwater currently exceed the MCL for Sr-90, Tc-99, I-129, and nitrate in the vicinity of INTEC. The groundwater model predicts that the SRPA will be restored to drinking water standards by 2095 for all COCs except Sr-90. The model predicts that the source of Sr-90 is currently below the alluvium in the interbeds and perched water system and a portion can be mobilized by infiltration. The Cs-137, which is immobile in the alluvium, will decay to acceptable levels. 
The response action selected in this ROD is necessary to protect the public health, welfare, or the environment from actual or threatened releases of hazardous substances into the environment. Such a release or threat of release may present an imminent and substantial endangerment to public health, welfare, or the environment. The remedial actions selected in this ROD are designed to reduce the potential threats to human health and the environment to acceptable levels. In addition, the Agencies have determined that no action is necessary under CERCLA to protect public health, welfare, or the environment at 16 sites located outside the tank farm boundary. 


\section{REMEDIAL ACTION OBJECTIVES}

The RAOs for OU 3-14 provide a general description of what the CERCLA cleanup is designed to accomplish. These goals serve as the design basis for the selected remedy identified in this ROD.

\subsection{Remedial Action Objectives for OU 3-14}

RAOs for the SRPA affected by INTEC sources are defined as follows:

I. Prior to 2095, prevent current workers and the general public from ingesting SRPA groundwater contaminated by INTEC releases that exceeds (1) MCLs, currently identified as $8 \mathrm{pCi} / \mathrm{L}$ for Sr-90, $900 \mathrm{pCi} / \mathrm{L}$ for Tc-99, $1 \mathrm{pCi} / \mathrm{L}$ for $\mathrm{I}-129$, and $10 \mathrm{mg} / \mathrm{L}$ for nitrate measured as nitrogen; (2) a cumulative excess cancer risk from all carcinogens of 1 in 10,000; or (3) an HI of 1.

II. In 2095 and beyond, ensure that concentrations of all contaminants in SRPA groundwater contaminated by INTEC releases do not exceed (1) MCLs; (2) a cumulative excess cancer risk from all carcinogens of 1 in 10,000; or (3) an HI of 1.

Total excess cancer risk and HI will be determined by summing contaminants that are predicted to be in the SRPA at the same place and time. The results of the BRA model predicted that Sr-90 would exceed the MCL of $8 \mathrm{pCi} / \mathrm{L}$ until 2129. No noncarcinogens have been identified that would exceed an MCL in 2095 and beyond, and the total HI is currently below 1 and predicted to remain below 1.

RAOs I and II can potentially be met through ICs; combinations of actions on the alluvium, the SRPA, and/or the vadose zone below the alluvium; and/or recharge controls on infiltration and anthropogenic water.

RAOs for the OU 3-14 soil are defined as follows:

III. Prevent external exposure to current and future workers inside the tank farm boundary from Cs-137 contaminated alluvium and prevent biotic transport that would exceed an excess cancer risk of 1 in 10,000 .

IV. Prevent external exposure to current workers at Sites CPP-15 and CPP-58 from Cs-137 contaminated alluvium that would exceed an excess cancer risk of 1 in 10,000.

V. Prevent internal exposure to biological receptors from Cs-137 and Sr-90 inside the tank farm boundary that would exceed an ecological hazard quotient of 10 for an individual contaminant and a total ecological HI of 10.

RAOs III and IV for soil are focused on external exposure to Cs-137, which represents the predominant risk. The risk and hazard quotient for other exposure routes, such as soil ingestion, are well below the risk threshold of $1 \times 10^{-4}$ or the hazard quotient of 1 and are extremely small $(0.0002 \%$ or less of the total) relative to impacts from external exposure. RAO III also addresses the potential for biotic transport of contamination as a possible pathway. Intrusion by deep-rooted plants and burrowing mammals and insects (such as ants) into contaminated soil can create a pathway for movement of contamination to the surface. This transported material could then be a potential source of exposure to human receptors on the surface. To ensure protection of workers, the remedy will inhibit transport of COCs to the surface by plants and animals. RAO V focuses on internal exposure for biological receptors. 


\subsection{Basis and Rationale for Remedial Action Objectives}

The basis for the RAOs for the soil is to clean up the site to industrial use standards, the anticipated future land use for this portion of INTEC.

The basis for the RAOs for groundwater is to ensure that current workers are not exposed to contaminated groundwater during implementation of the selected remedy and to restore groundwater to MCLs for hypothetical future residents living at INTEC (outside the industrial use area) and future INTEC workers.

\subsection{Risks Addressed by the Remedial Action Objectives}

The risks associated with Cs-137 contaminated soil will be addressed by containment until the Cs-137 decays to risk levels below $1 \times 10^{-4}$ for a future worker. The risks associated with ingestion of contaminated INTEC groundwater will be addressed through (1) ICs until the portion of the SRPA contaminated by INTEC releases is restored to MCLs or below on or before 2095 and (2) reducing infiltration. 


\section{REMEDIATION GOALS}

Remediation goals (RGs) are established based on the results of the BRA and the evaluation of expected exposures and risks for selected alternatives. The remediation goals will be used to assess the effectiveness of the selected remedial alternatives in meeting the RAOs.

Groundwater RGs are based on meeting the MCLs in the portion of the SRPA contaminated by INTEC releases by 2095 and beyond and are presented in Table 9-1. The RG for beta-gamma-emitting radionuclides (H-3, I-129, Tc-99, and Sr-90 and its daughters) is restricted to a cumulative dose of $4 \mathrm{mrem} / \mathrm{yr}$ in 2095 and beyond. The cumulative dose is determined by contaminants that overlap in space and time. The cumulative dose from alpha-emitting radionuclides (such as Am-241, Np-237, and Pu isotopes) is much lower than the MCL of $15 \mathrm{pCi} / \mathrm{L}$ for all alpha-emitting radionuclides.

Table 9-1. Groundwater remediation goals for the year 2095 and beyond.

\begin{tabular}{|c|c|}
\hline Contaminant of Concern ${ }^{\mathrm{a}}$ & Remediation Goal \\
\hline Sr-90 & $8 \mathrm{pCi} / \mathrm{L}$ \\
\hline Total (Sr-90, I-129, and Tc-99) & $4 \mathrm{mrem} / \mathrm{yr}$ \\
\hline
\end{tabular}

The RGs for Cs-137 in OU 3-14 soil were developed from EPA PRGs (EPA 2006a). EPA PRGs are back-calculated, current soil concentrations that correspond to a risk of 1 in 1,000,000. They are calculated using standard EPA exposure route equations and EPA cancer slope factors.

For future outdoor workers, the EPA PRG for outdoor worker soil was initially selected. Because EPA PRGs are calculated for a 1-in-1,000,000 target risk criteria, they were multiplied by 100 to obtain the RGs for the 1-in-10,000 risk criteria for the OU 3-14 sites. The RG for an outdoor worker having a $1 \times 10^{-4}(1$-in-10,000) risk-based level for external exposure to Cs- 137 was calculated to be $11.3 \mathrm{pCi} / \mathrm{g}$ in 2095. This calculation was based on a worker spending 40 hours per week on the tank farm, for 50 weeks per year, and for 25 years (2095 to 2120). Current workers are protected by ICs.

Due to radioactive decay, the RG depends on the year the cleanup is performed. The calculated outdoor worker RG for year 2095 of $11.3 \mathrm{pCi} / \mathrm{g}$ is used to calculate the $\mathrm{RG}$ for any year from the present to 2095 by dividing the RG by an exponential decay factor. This decay factor was calculated as [ $\mathrm{e}^{-\lambda t}$ ], where $\lambda$ is the Cs-137 decay rate constant $\left(0.023 \mathrm{yr}^{-1}\right)$ and $\mathrm{t}$ is the decay time (in years) between the cleanup date and 2095 when the future worker exposure scenario begins.

For example, the Cs-137 RG in 2006 is calculated as

$$
11.3 \mathrm{pCi} / \mathrm{g} / \mathrm{e}^{-\left[\left(0.023 \mathrm{yr}^{-1}\right)(89 \mathrm{yr})\right]}=87.5 \mathrm{pCi} / \mathrm{g} .
$$

Example calculations for future years are summarized in Table 9-2. 
Table 9-2. Soil remediation goals for Cs-137 for various remedial decision dates.

\begin{tabular}{|l|c|}
\hline \multicolumn{1}{|c|}{ Remedial Decision Date } & $\begin{array}{c}\text { Cs-137 Soil Remediation Goal } \\
\text { (pCi/g) }\end{array}$ \\
\hline 2095 & 11.3 \\
\hline 2035 (projected INTEC facility closure) & 45 \\
\hline 2012 (projected TFF closure) & 76 \\
\hline
\end{tabular}

The RG will apply to the top $4 \mathrm{ft}$ of alluvium in the industrial use area. The RGs will be used to verify the effectiveness of the selected remedial action and to determine if additional remedial action is necessary prior to termination of the remedial action. 


\section{DESCRIPTION OF ALTERNATIVES}

This section describes remedial alternatives developed to meet the RAOs cited in Section 8. As required under the NCP (40 CFR 300.430), technologies that may potentially meet RAOs were identified and screened. Representative technologies were selected from those retained after screening, and the retained technologies were combined into a range of alternatives, including

- Source control alternatives involving treatment of contamination to reduce the toxicity, mobility, and volume of contamination

- Alternatives involving little or no treatment but providing protection of human health and the environment by preventing exposures to receptors, e.g., containment and ICs

- Groundwater alternatives that attain RGs within different restoration time periods using one or more different technologies.

The alternatives were formulated to meet RAOs while adding progressively more protective measures; therefore, some elements are common to several or all of the alternatives.

Groundwater modeling was used to predict the effect on SRPA water quality of potential remedial alternatives under OU 3-14, in combination with potential remedies under OU 3-13. The model predicts that the most effective way to meet the groundwater RAOs is to control recharge to the SRPA by reducing infiltration of precipitation to $1 \mathrm{~mm} /$ year or less over a 10 -acre area around and including the tank farm. Figure 4-1 shows this recharge control zone (RCZ).

The modeling also predicted that removing or treating the contaminated alluvium does not significantly reduce risk to the SRPA because the mobile Sr-90 has already migrated to the perched water and the residual Sr-90 contamination in the alluvium is essentially immobile. Furthermore, the model predicted that lining the BLR near INTEC would have a negligible effect on risk because infiltration of river water does not recharge the shallow perched water directly under the tank farm.

The alternatives will be described in reference to the RCZ border (area outside the tank farm) and the north, central, and south tank farm as shown on Figure 4-1. The central tank farm includes Site CPP-31, where most of the contamination was released from the tank farm to the alluvium and underlying groundwater, and includes underground tanks WM-180 through WM-190 as well as extensive surface infrastructure projected to be removed from service by 2012. The north tank farm has no release sites and has not been characterized but is considered part of CPP-96. The south tank farm includes release sites CPP-20, CPP-25, CPP-27, and CPP-33; the berm adjacent to CPP-604; and buried tanks WM-100 through WM-102 and WL-101, WL-102, and WL-133. It is adjacent to infrastructure projected to remain active through 2035, including Buildings CPP-604, CPP-605, CPP-756, and the main stack. Following closure of the TFF tanks in 2012, INTEC cleanup and closure activities will continue with completion expected in 2035. Several components of tank farm infrastructure (transfer pipelines and valve boxes) are required for INTEC closure activities and will remain active beyond tank closure. This infrastructure is shown in purple in Figure 4-1.

Because of the preference in the NCP for treatment, an SRPA pump and treat alternative was evaluated. Small, mobile fractions of Sr-90 from the northern perched water and interbeds (originating from the tank farm and from the deep vadose zone [injection well failure]) are predicted to slowly move down to the SRPA. Based on technical limitations, pump and treat would be very inefficient at removing Sr-90. The model predicted that if pump and treat started in 2077 (design based on manual iterations), it would need to continue until 2123. Less than $0.1 \mathrm{Ci}$ of $\mathrm{Sr}-90$ could be removed each year from the SRPA. 
Over 45 years of pumping, this alternative would remove less than $4.5 \mathrm{Ci}$ of Sr-90. A contingent pump and treat alternative was evaluated in detail in the OU 3-14 FS, Appendix A (DOE-ID 2006d). In addition to the inefficiency of pumping and treatment, the technical practicability of selecting a remedy for groundwater that would not be implemented for 70 years is very low. For these reasons, SRPA pump and treat will not be considered further in this ROD. The other alternatives are summarized below.

\subsection{No Action Alternative}

DOE is required by federal orders and state and federal laws to protect workers and the public from unacceptable exposures, and the INL Site currently has administrative and physical controls in place to prevent unacceptable exposures to contaminated soil and groundwater. DOE cannot implement a no action alternative (i.e., no controls) because it would put workers at risk and would not meet the requirements of federal orders and state and federal laws. Therefore, the no action alternative is not considered further.

\subsection{Alternative 1 - Limited Action}

The limited action alternative includes all of the ongoing OU 3-13 remedies for tank farm soil and groundwater and serves as a basis for comparison in the FS against the other alternatives as required under the NCP. This alternative includes

- Institutional controls for OU 3-14 soil and the SRPA until 2095

- $\quad$ Operating and maintaining existing surface water controls implemented under the TFIA

- $\quad$ Monitoring the SRPA until 2095.

Existing ICs will remain in effect as long as hazards remain that limit unrestricted use of the site for the planned land use, i.e., through at least 2095 for the tank farm. These ICs include the control of activities, access restrictions, and restrictions on leasing or transferring property, as described in the INL Sitewide Institutional Controls Plan (DOE-ID 2006c), and maintaining notification requirements in response to failed control/corrective action. The ICs will be maintained on both OU 3-14 soil and the SRPA. Operations and maintenance (O\&M) will continue on the IC components through inspection of CPP-96 that will lead to necessary updates to the INL Sitewide Institutional Controls Plan. O\&M of the TFIA components will continue as described in DOE-ID (2006e). This will include O\&M of the paved areas in and around the tank farm, the lift station, the evaporation pond (see Figure 1-1) and leak detection system, and the lined drainage ditches and culverts that are used to transfer surface water run-off away from the tank farm and to the evaporation pond. Monitoring of the SRPA, currently addressed under OU 3-13, would continue under OU 3-14 using existing wells.

Soil exposure carcinogenic risks identified for future workers would remain unchanged for Alternative 1 if ICs end. The direct radiation exposure risk for a worker inside the tank farm border would remain above $1 \times 10^{-4}$ for about 220 years or until about 2227. Direct exposure risks to workers at CPP-15 and CPP-58 would decrease to allowable levels before 2095. Risks to ecological receptors due to radionuclides in soil would not be mitigated by this alternative.

Ingestion of contaminated groundwater would be administratively prevented until at least 2095 . From 2095 until 2129, Sr-90 concentrations in the SRPA would remain above acceptable levels for ingestion by hypothetical future residents living outside the industrial use area or future workers, based on BRA groundwater modeling predictions. 


\subsection{Alternative 2 - Containment and Monitoring}

Alternative 2, illustrated in Figure 10-1, expands upon the actions in Alternative 1:

- $\quad$ Cover the RCZ outside the tank farm with low-permeability pavement.

- $\quad$ Cap the central and south tank farm with an evapotranspiration cap with a capillary biobarrier (ET/CB).

- Install a protective cover over the north tank farm. Characterize the north tank farm soil for Cs-137 in the top $4 \mathrm{ft}$ and

a) If soil is less than the future worker RG, cover the north tank farm with low-permeability pavement or

b) If soil is above the future worker RG, remove soil contaminated above the future worker RG prior to installing low-permeability pavement.

- $\quad$ Maintain, modify, and upgrade as necessary, the TFIA components as the remedy is implemented until at least 2095. Components include lined drainage ditches, culverts, an evaporation pond, and a lift station.

- $\quad$ Monitor and maintain the ET/CB.

- Implement ICs for OU 3-14 soil and the SRPA until 2095.

- Monitor the portion of the SRPA contaminated by INTEC releases until MCLs have been met (expected to be on or before 2095).

The RCZ outside the tank farm, about 3.5 acres excluding aboveground infrastructure, and the north tank farm, about 0.5 acre, would be covered with 4-6 in. of low-permeability pavement, the features of which are shown on Figure 10-2. This type of cover can be readily installed around existing infrastructure, such as the concrete pad over Site CPP-15, and can be easily expanded as facility infrastructure is removed. This cover requires ongoing maintenance to ensure its effectiveness (such as patching) and use of lift stations to transport accumulated surface water to a lined evaporation pond.

The central and south tank farm, about 3.2 acres and 0.7 acres, respectively, would be capped with an ET/CB. Figure 10-3 shows the features of this cap. The ET/CB varies in thickness from $6 \mathrm{ft}$ at the edges to $18 \mathrm{ft}$ at the crown and would protect workers from external exposure to contaminated soil, reduce water infiltration, and prevent biota from intruding through the cap and bringing contamination to the surface. This type of cap requires less maintenance than the low-permeability pavement and does not require lift stations or evaporation ponds for managing surface water. Instead, it minimizes recharge by storing moisture and returning it to the air using plants and evaporation.

The immediate installation of the ET/CB over the south tank farm is prevented by ongoing INTEC cleanup activities that require access to Buildings CPP-604, CPP-605, and CPP-1659, and other infrastructure, including active underground waste lines and tanks (see Figure 4-1). Therefore, the south tank farm would initially be covered with low-permeability pavement to reduce infiltration to the northern perched water until after INTEC closure ( 2035) when the south tank farm would be covered with an $\mathrm{ET} / \mathrm{CB}$. 


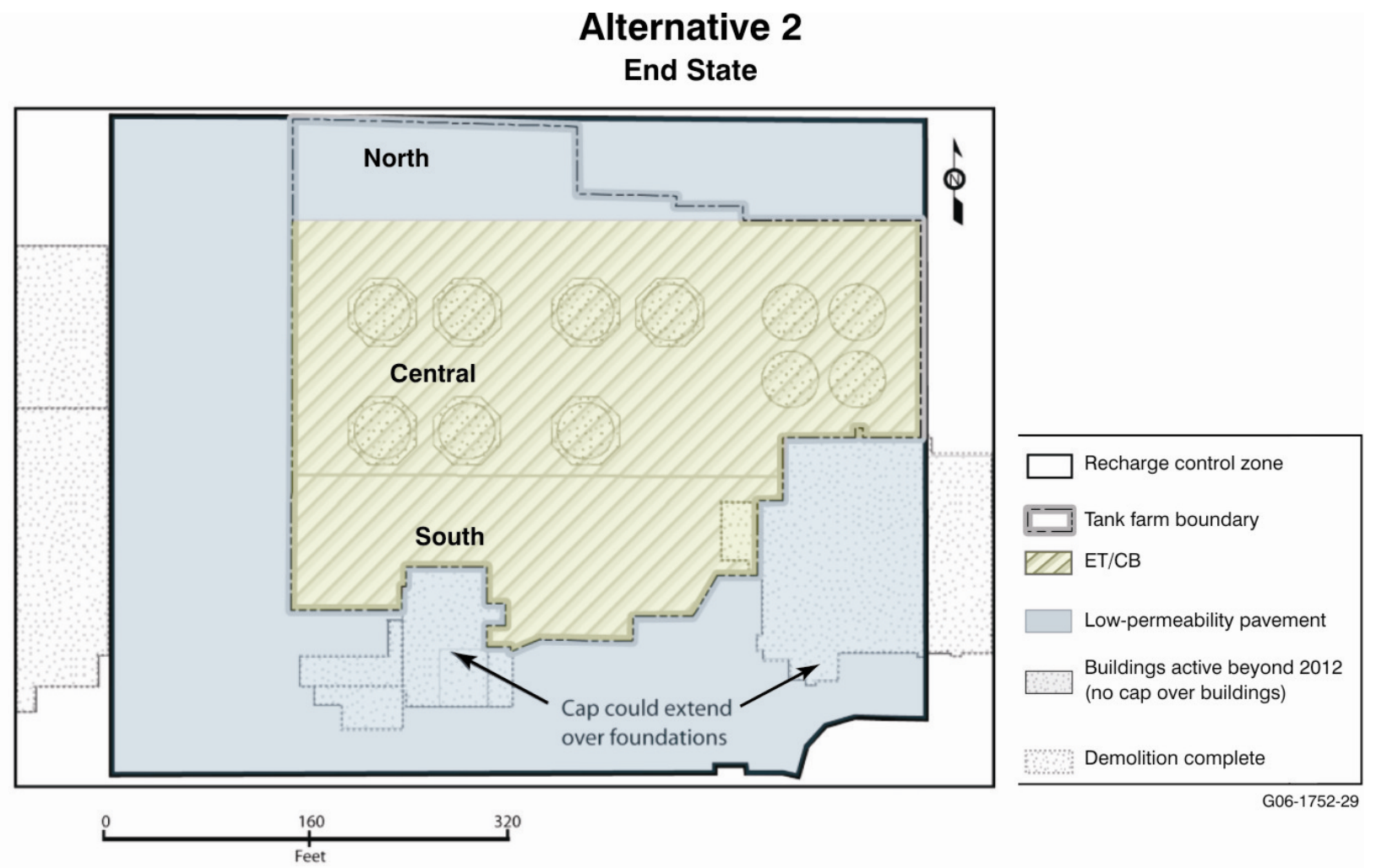

Figure 10-1. Alternative 2, Containment and Monitoring.

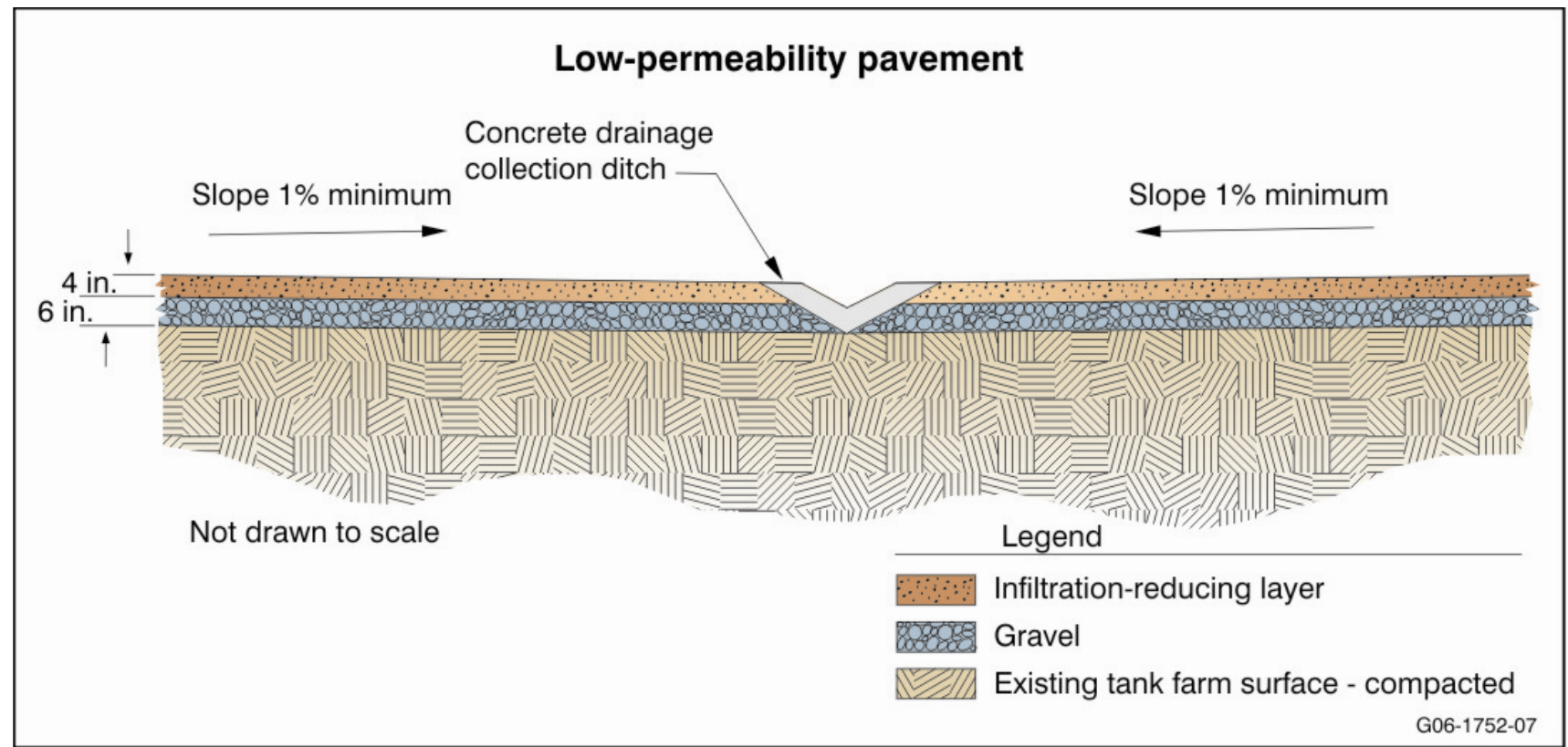

Figure 10-2. Conceptual design features of the low-permeability pavement. 


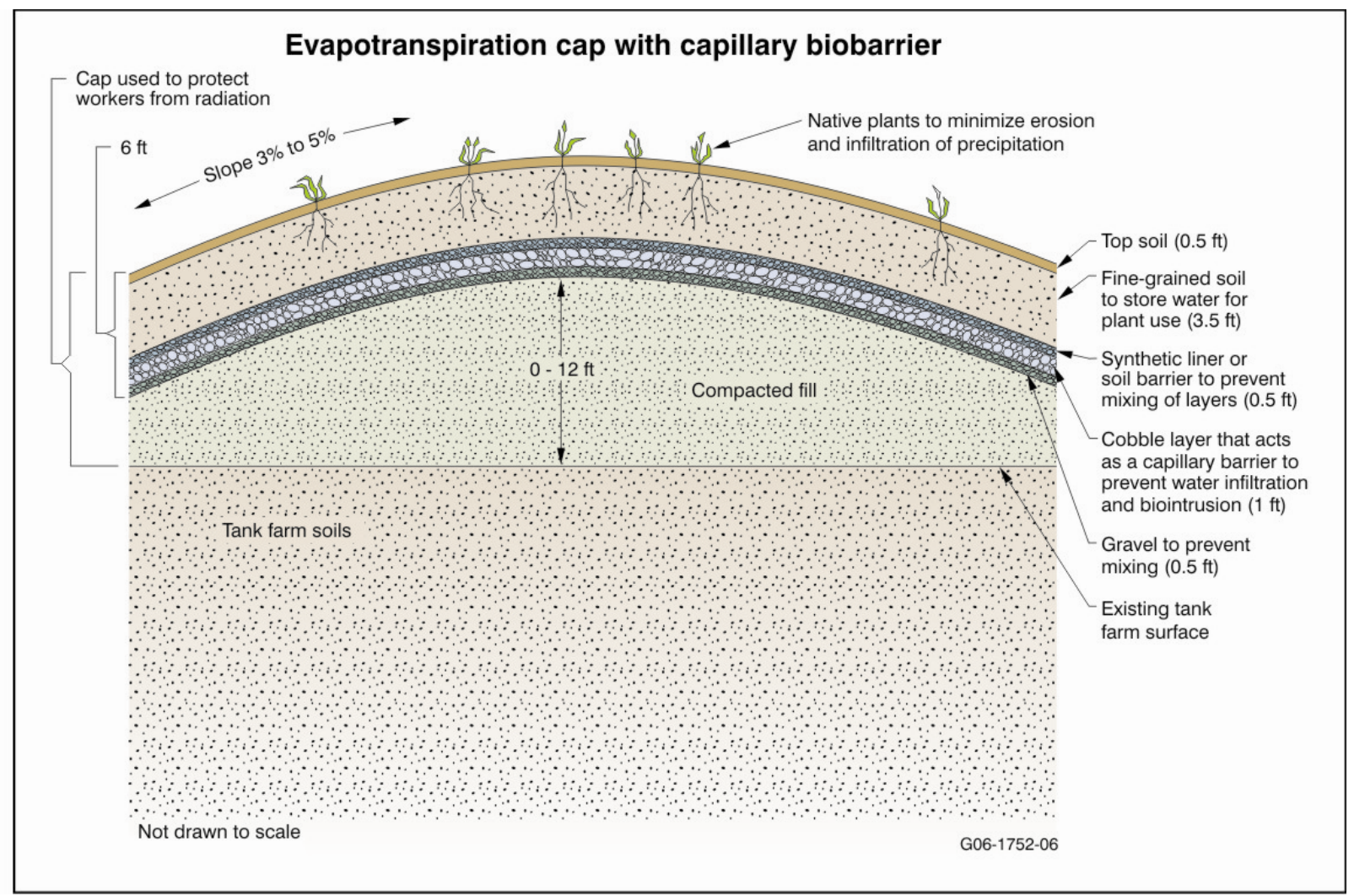

Figure 10-3. Conceptual design features of the evapotranspiration cap with capillary biobarrier.

The north tank farm area will be characterized to determine Cs-137 levels in the top $4 \mathrm{ft}$ of soil. If the soil is above the RGs, a determination will be made whether to remove contaminated soil before installing the same low-permeability pavement planned for the RCZ outside the tank farm or whether to leave the contaminated soil in place and extend the central tank farm ET/CB to cover the north tank farm area. Excavated soil will be disposed of in the ICDF, which is scheduled for last receipt of waste in 2013 and closure in 2015. (ICDF was assumed to be the disposal location for contaminated soil and debris, secondary waste, and investigation-derived waste only through 2013, with an equivalent facility assumed to be available after that.)

Until the ET/CB is installed, worker exposures would be reduced to allowable levels by administrative controls and access restrictions discussed under Alternative 1. The ET/CB would provide additional worker protection for the duration of unacceptable risk. Environmental risks would be reduced or eliminated by the ET/CB. Worker ingestion of contaminated groundwater would be administratively controlled until at least 2095 by providing drinking water from production wells located outside the plume. In 2095 and beyond, Sr-90 concentrations in the SRPA would be at allowable levels for ingestion by hypothetical future residents living outside the industrial use area based on modeling results of reducing infiltration over 10 acres.

The central tank farm ET/CB can be installed directly following TFF closure, which will require extending active valve boxes to the surface of the cap and constructing retaining walls to protect Buildings CPP-604/CPP-605 and CPP-659, which house critical ventilation and evaporation processes. Or, the central tank farm ET/CB can be installed following INTEC closure and following DD\&D of all remaining infrastructure. Therefore, two variants of Alternative 2 will be presented, installing the ET/CB on the central tank farm following TFF closure (Option a) or following INTEC closure (Option b). 


\subsubsection{Alternative 2a}

Alternative 2a would be completed before INTEC closure, with the exception of the south tank farm (see the top of Figure 10-4). Low-permeability pavement would be installed over the RCZ outside the tank farm, north tank farm, and south tank farm and integrated into existing buildings and structures. This low-permeability pavement would be maintained and expanded as INTEC infrastructure was removed.

After DD\&D of inactive surface infrastructure (following tank farm closure) in the central tank farm, the ET/CB would be installed. Retaining walls would be installed around active infrastructure, surface water drainage would be rerouted as necessary, and valve boxes in the cap area would be extended to allow access to valves on active transfer lines. As the peripheral infrastructure is no longer needed and removed, the retaining walls would be removed and the ET/CB would be contoured in these areas. The south tank farm would initially be covered with low-permeability pavement to reduce infiltration to the aquifer until after INTEC closure ( 2035) when the south tank farm would be covered with an ET/CB. Table 10-1 presents the timing for installation of each component of Alternative 2a.

\subsubsection{Alternative $2 b$}

Alternative $2 \mathrm{~b}$ is similar to Alternative $2 \mathrm{a}$, except for the central tank farm where a low-permeability pavement will be installed followed by an ET/CB. Following TFF closure, low-permeability pavement would be installed over the central tank farm (see bottom left drawing on Figure 10-4). After INTEC closure, when the interfering infrastructure is no longer needed and has been closed, the ET/CB would be constructed on top of the low-permeability pavement (see drawing on right side of Figure 10-4).

The ET/CB would be installed over both the central and south tank farm during a single effort. The ET/CB could be extended over a larger area (for example, the north tank farm) and combined with other caps if that is more cost-effective than maintaining the low-permeability pavement. The final capping configuration of Alternatives $2 a$ and $2 b$, after removal of interfering infrastructure, would be identical. Table 10-1 presents the timing for installation of each component of Alternative $2 \mathrm{~b}$.

OU 3-14 actions to be completed initially, between 2008 and immediately following TFF closure planned for 2012, will be fully protective of workers through administrative controls and access restrictions and will reduce risks to groundwater. This allows for staged implementation of additional components after the interfering infrastructure is removed or no longer in use, which is estimated to be after 2035. These additional remedy components will add measures for long-term protection of workers and biota, while minimizing long-term maintenance requirements.

\subsection{Alternative 3 - Hot Spot Removal, Containment, and Monitoring}

Alternative 3 would add the following actions to those implemented under Alternative 2:

- $\quad$ Removal of contaminated alluvium at CPP-31

- Disposal at ICDF

- $\quad$ Backfilling with clean material. 


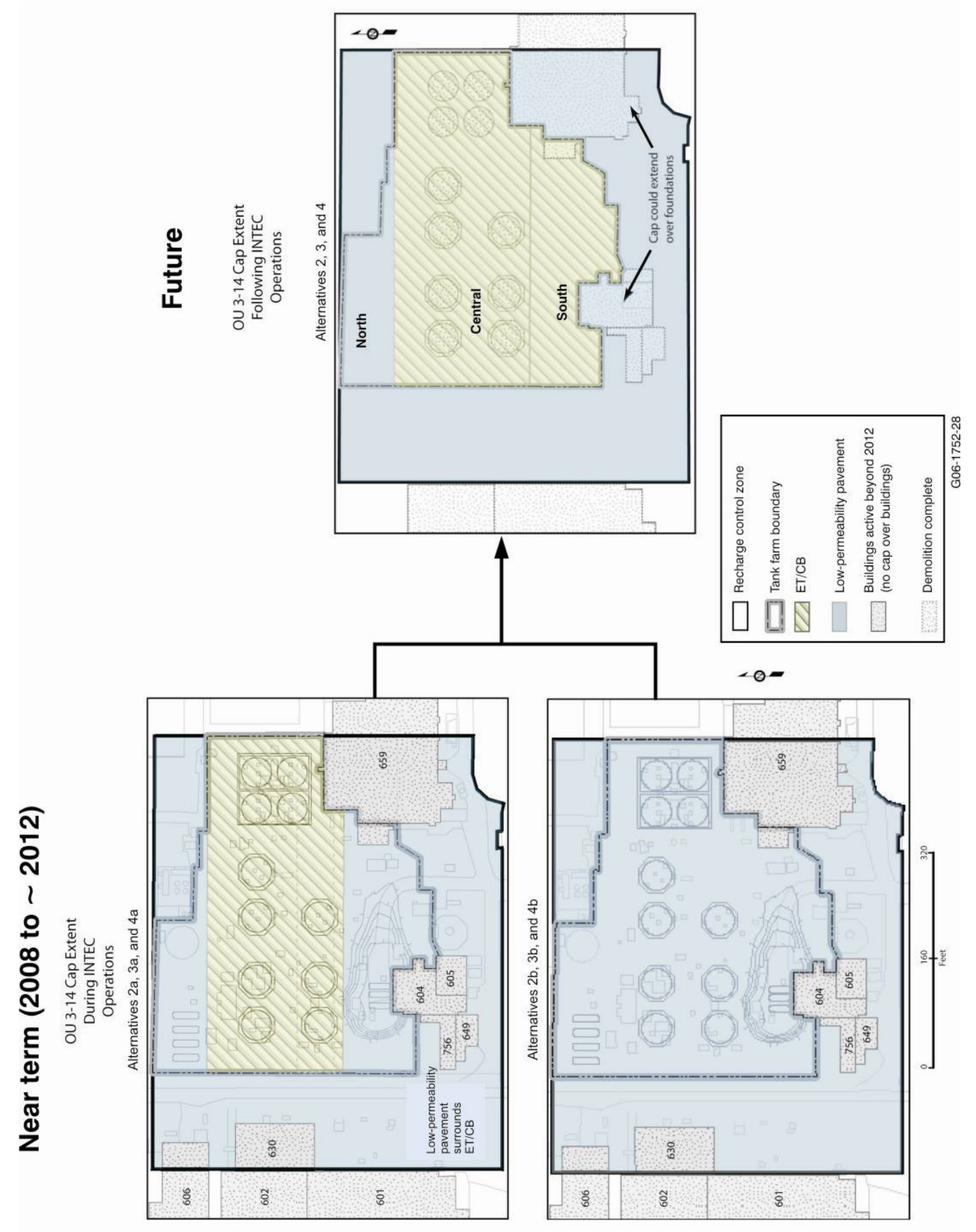

Figure 10-4. Cap extent for Alternatives 2 through 4 during and following facility operation. 
Table 10-1. Installation timing for alternatives.

\begin{tabular}{|c|c|c|c|c|c|c|c|}
\hline Area & Remedy & $\begin{array}{l}\text { Alternative } 2 \mathrm{a} \\
\text { Containment and } \\
\text { Monitoring }\end{array}$ & $\begin{array}{l}\text { Alternative } 2 \mathrm{~b} \\
\text { Containment and } \\
\text { Monitoring }\end{array}$ & $\begin{array}{c}\text { Alternative 3a } \\
\text { Hot Spot Removal, } \\
\text { Containment, and } \\
\text { Monitoring }\end{array}$ & $\begin{array}{c}\text { Alternative } 3 b \\
\text { Hot Spot Removal, } \\
\text { Containment, and } \\
\text { Monitoring }\end{array}$ & $\begin{array}{l}\text { Alternative } 4 \mathrm{a} \\
\text { In Situ Treatment, } \\
\text { Containment, and } \\
\text { Monitoring }\end{array}$ & $\begin{array}{c}\text { Alternative } 4 \mathrm{~b} \\
\text { In Situ Treatment, } \\
\text { Containment, and } \\
\text { Monitoring }\end{array}$ \\
\hline $\begin{array}{l}\text { RCZ outside the tank } \\
\text { farm }\end{array}$ & Low-permeability pavement & Before TFF closure ${ }^{\mathrm{a}}$ & Before TFF closure & Before TFF closure & Before TFF closure & Before TFF closure & Before TFF closure \\
\hline \multirow[t]{3}{*}{ North tank farm } & $\begin{array}{l}\text { If soil }<\mathrm{RG} \text {, low-permeability } \\
\text { pavement }\end{array}$ & \multirow[b]{2}{*}{ Before TFF closure } & \multirow[b]{2}{*}{ Before TFF closure } & \multirow[b]{2}{*}{ Before TFF closure } & \multirow[b]{2}{*}{ Before TFF closure } & \multirow[b]{2}{*}{ Before TFF closure } & \multirow[b]{2}{*}{ Before TFF closure } \\
\hline & $\begin{array}{l}\text { If soil > RG, } \\
\text { - Excavate and low-permeability } \\
\text { pavement }\end{array}$ & & & & & & \\
\hline & or & $\mathrm{NA}^{\mathrm{c}}$ & After INTEC closure ${ }^{d}$ & NA & After INTEC closure & NA & After INTEC closure \\
\hline \multirow[t]{4}{*}{ Central tank farm } & Low-permeability pavement & NA & After TFF closure & NA & After TFF closure & NA & After TFF closure \\
\hline & $\mathrm{ET} / \mathrm{CB}$ & After TFF closure & After INTEC closure & After TFF closure & After INTEC closure & After TFF closure & After INTEC closure \\
\hline & CPP-31 excavation & NA & NA & After TFF closure & After INTEC closure & NA & NA \\
\hline & CPP-31 in situ treatment & NA & NA & NA & NA & After TFF closure & After INTEC closure \\
\hline \multirow[t]{2}{*}{ South tank farm } & Low-permeability pavement & Before TFF closure & Before TFF closure & Before TFF closure & Before TFF closure & Before TFF closure & Before TFF closure \\
\hline & $\mathrm{ET} / \mathrm{CB}$ & After INTEC closure & After INTEC closure & After INTEC closure & After INTEC closure & After INTEC closure & After INTEC closure \\
\hline
\end{tabular}


Site CPP-31 was the source of the largest OU 3-14 contaminant release to the alluvium and the underlying basalt and perched water. A relatively small fraction of the approximately $15,900 \mathrm{Ci}$ of $\mathrm{Sr}-90$ originally released is estimated to remain in the alluvium at CPP-31. The modeling predicts that the residual Sr-90 in the alluvium is essentially immobile and will not contribute significantly to groundwater risk. Given the immobile nature of Cs-137, most of it remains in the alluvium. Removal of contaminated alluvium would require worker protection from gamma radiation. As a result, excavation would likely be performed using remote handling techniques, which complicates this alternative. Because excavation using remote handling techniques would be to $60 \mathrm{ft}$ deep in some areas but limited horizontally to $50 \mathrm{ft}$ due to the distance between tank vaults, ramps and shoring would also be required. Excavated alluvium would be transported to ICDF for disposal and the excavation backfilled with clean fill.

Removal of contaminated alluvium at CPP-31 would provide no additional worker protection beyond that resulting from administrative controls through 2095 and capping the south and central tank farm with the ET/CB. After 2095, the ET/CB would maintain worker protection for the duration of unacceptable risk. Environmental risks would be reduced or eliminated by the ET/CB.

Excavating and disposing of contaminated CPP-31 alluvium, combined with capping, would achieve Sr-90 MCLs in the SRPA approximately 5 years sooner than just reducing infiltration over 10 acres. Sr-90 concentrations in the SRPA would remain above MCLs until approximately 2090 (as compared to 2095 for Alternative 2). Ingestion of the SRPA contaminated by INTEC releases would be administratively prevented until MCLs are attained. In 2090 and beyond, Sr-90 concentrations in the SRPA would be at allowable levels for ingestion by hypothetical future residents living outside the industrial use area.

There are two variants of Alternative 3. The difference between the two options is when CPP-31 is excavated and the ET/CB is constructed, either following TFF closure (Option a) or following INTEC closure (Option b).

\subsubsection{Alternative 3a}

Contaminated alluvium at Site CPP-31 would be excavated and disposed of at the ICDF, and the excavation would be backfilled with clean soil before constructing the ET/CB over the central tank farm. Excavation and cap construction would both occur immediately following tank farm closure. Other than excavating Site CPP-31, the paving/capping remedy would follow the sequence described for Alternative $2 \mathrm{a}$ (see top left and right drawings on Figure 10-4). Table 10-1 presents the timing for installation of each component of Alternative 3a.

\subsubsection{Alternative $3 b$}

In this alternative, the low-permeability pavement would be installed over the contaminated alluvium at Site CPP-31. Following INTEC closure, Site CPP-31 would be excavated and disposed of at an equivalent facility to the ICDF, and the excavation would be backfilled with clean soil. Other than excavating Site CPP-31, the paving/capping remedy would follow the sequence of activities described for Alternative $2 \mathrm{~b}$ (see bottom left and right drawings on Figure 10-4). Table 10-1 presents the timing for installation of each component of Alternative $3 \mathrm{~b}$. 


\subsection{Alternative 4 - In Situ Hot Spot Treatment, Containment, and Monitoring}

Alternative 4 adds the following actions to those implemented under Alternative 2:

- In situ treatment of contaminated alluvium at Site CPP-31 using injection of cementitious grout

- $\quad$ Disposal of grout returns at ICDF or an equivalent facility.

The alluvium within Site CPP-31, from the surface down to the basalt interface, would be grouted to ensure that the $\mathrm{Sr}-90$ remaining in the alluvium is immobilized. Some grout and drill cuttings would be forced out of the drill annulus in any grouting scenario. These grout returns would be contaminated and are assumed to require remote handling, thereby requiring increased work controls to protect workers.

Grouting the contaminated alluvium at CPP-31 would provide no additional worker protection beyond that resulting from administrative controls through 2095 and capping the south and central tank farm with the ET/CB. After 2095, the ET/CB would maintain worker protection for the duration of risk. Environmental risks would be reduced or eliminated by the ET/CB.

Treating contaminated alluvium in situ at Site CPP-31, combined with capping, would provide only a very minor reduction in the Sr-90 concentration in the SRPA compared to just reducing infiltration over 10 acres. This is because the Sr-90 in the alluvium is already essentially immobile and grouting provides little additional benefit. Sr-90 concentrations in the SRPA would remain above the MCL until approximately 2090 (as compared to 2095 for Alternative 2). Groundwater ingestion by workers would be administratively controlled until at least 2090. In 2090 and beyond, Sr-90 concentrations in the SRPA would be at allowable levels for ingestion by hypothetical future residents living outside the industrial use area.

Because of buried and surface infrastructure at CPP-31, only about half of the grout holes installed would reach the alluvium-basalt interface, resulting in less than $100 \%$ of the contaminated alluvium being contacted by grout. Grouting after TFF closure (Option a) and grouting after INTEC closure (Option b) for Alternative 4 are described below.

\subsubsection{Alternative 4a}

Contaminated alluvium at Site CPP-31 would be grouted in situ prior to constructing the ET/CB over the central tank farm. Other than this grouting, the paving/capping remedy would follow the sequence described for Alternative 2a (see top left and right drawings on Figure 10-4). Table 10-1 presents the timing for installation of each component of Alternative $4 \mathrm{a}$.

\subsubsection{Alternative 4b}

The low-permeability pavement would be constructed over the central tank farm and maintained until INTEC closure. Contaminated alluvium at Site CPP-31 would then be grouted in situ prior to constructing the ET/CB over the central tank farm. Other than this grouting, the paving/capping remedy would follow the sequence of activities described for Alternative $2 b$ (see bottom left and right drawings on Figure 10-4). Table 10-1 presents the timing for installation of each component of Alternative $4 \mathrm{~b}$. 


\section{COMPARATIVE ANALYSIS OF ALTERNATIVES}

The alternatives were evaluated using the nine evaluation criteria specified by CERCLA (40 CFR 300.430(f)(5)(i)). The purpose of this evaluation is to identify the relative advantages and disadvantages of each alternative. The alternatives are compared to each other and the comparative analysis is summarized below. The relative performance of each alternative is described in Table 11-1.

\subsection{Overall Protection of Human Health and the Environment}

This criterion addresses whether each alternative provides adequate protection of human health and the environment and describes how risks posed through each exposure pathway are eliminated, reduced, or controlled through treatment, engineering controls, and/or ICs. RAOs are used as a measure of how well an alternative meets this criterion.

All alternatives (1, 2a, 2b, 3a, 3b, 4a, and 4b) would meet RAO I by implementing ICs, including access restrictions through at least 2095.

Alternatives 2a, 2b, 3a, 3b, 4a, and $4 \mathrm{~b}$ would meet RAO II by combining ICs with capping to reduce infiltration in the RCZ. By reducing this infiltration, the modeling predicts that the MCLs would be met by 2095 for the portion of the SRPA contaminated by INTEC releases.

Installing a final ET/CB on the central tank farm after closure of the TFF, as for Alternatives 2a, $3 a$, and $4 a$, versus after INTEC closure, as for Alternatives $2 b, 3 b$, and $4 b$, would have no effect on attainment of RAO II, because the interim low-permeability pavement would be maintained to provide adequate infiltration control.

Alternative 1 meets RAO III for current workers only (not future), because active ICs are assumed to end in 2095, and meets RAO IV. DOE will not rely on ICs alone as a sole remedy after 2095; therefore, Alternative 1 does not meet RAO III after 2095. Alternatives 2a, 2b, 3a, 3b, 4a, and 4b meet RAOs III and IV by maintaining ICs through 2095 and by removing, grouting, or capping contaminated soil.

Alternative 1 does not meet RAO V because ICs, operations and maintenance, and monitoring were assumed to not prevent exposures to ecological receptors. Alternatives 2a, 2b, 3a, 3b, 4a, and 4b would meet RAO V by removing or capping contaminated soil.

\subsection{Compliance with Applicable or Relevant and Appropriate Requirements}

Per Section 121(d) of CERCLA (42 USC 9621(d)) and the NCP (40 CFR 300.430(f)(1)(ii)(B)), remedial actions at CERCLA sites must attain applicable or relevant and appropriate requirements (ARARs), unless waived under CERCLA Section 121(d)(4) (42 USC 9621(d)(4), Public Law 99-499). ARARs are promulgated, or legally enforceable, federal and state requirements. EPA has also developed another category, known as "to be considered," that includes nonpromulgated criteria, advisories, guidance, and proposed standards issued by federal or state governments. Since to-be-considered criteria are nonbinding, they are not included in this list. Applicable requirements are those cleanup standards, standards of control, and other substantive requirements, criteria, or limitations promulgated under federal environmental or state environmental or facility siting laws that specifically address a hazardous substance, pollutant, contaminant, remedial action, location, or other circumstance found at a CERCLA 
Table 11-1. Detailed analysis summary for the OU 3-14 tank farm soil and groundwater

\begin{tabular}{|c|c|c|c|c|c|c|c|}
\hline \multirow[b]{2}{*}{ Criteria } & \multirow{2}{*}{$\begin{array}{l}\text { Alternative } 1 \\
\text { Limited Action }\end{array}$} & \multicolumn{2}{|c|}{$\begin{array}{c}\text { Alternative } 2 \\
\text { Containment and Monitoring } \\
\end{array}$} & \multicolumn{2}{|c|}{$\begin{array}{c}\text { Alternative } 3 \\
\text { Hot Spot Removal, Containment, and Monitoring }\end{array}$} & \multicolumn{2}{|c|}{$\begin{array}{c}\text { Alternative } 4 \\
\text { Hot Spot Treatment, Containment, and Monitoring } \\
\end{array}$} \\
\hline & & $2 \mathrm{a}$ & $2 \mathrm{~b}$ & $3 a$ & $3 \mathrm{~b}$ & $4 \mathrm{a}$ & $4 \mathrm{~b}$ \\
\hline \multicolumn{8}{|c|}{ Overall protection of human health and the environment (threshold criterion) } \\
\hline Human health protection & $\begin{array}{l}\text { Protective of human health } \\
\text { using existing ICs through } \\
\text { 2095. Not protective beyond } \\
2095\end{array}$ & $\begin{array}{l}\text { Soil and groundwater } \\
\text { exposure risks are controlled } \\
\text { for duration of risk }\end{array}$ & $\begin{array}{l}\text { Soil and groundwater } \\
\text { exposure risks are controlled } \\
\text { for duration of risk }\end{array}$ & $\begin{array}{l}\text { Soil and groundwater } \\
\text { exposure risks are controlled } \\
\text { for duration of risk }\end{array}$ & $\begin{array}{l}\text { Soil and groundwater } \\
\text { exposure risks are controlled } \\
\text { for duration of risk }\end{array}$ & $\begin{array}{l}\text { Soil and groundwater } \\
\text { exposure risks are controlled } \\
\text { for duration of risk }\end{array}$ & $\begin{array}{l}\text { Soil and groundwater } \\
\text { exposure risks are controlled } \\
\text { for duration of risk }\end{array}$ \\
\hline Environmental protection & $\begin{array}{l}\text { Allows continued ecological } \\
\text { exposures }\end{array}$ & $\begin{array}{l}\text { Soil exposure risks are } \\
\text { controlled for duration of risk }\end{array}$ & $\begin{array}{l}\text { Soil exposure risks are } \\
\text { controlled for duration of risk }\end{array}$ & $\begin{array}{l}\text { Soil exposure risks are } \\
\text { controlled for duration of risk }\end{array}$ & $\begin{array}{l}\text { Soil exposure risks are } \\
\text { controlled for duration of risk }\end{array}$ & $\begin{array}{l}\text { Soil exposure risks are } \\
\text { controlled for duration of risk }\end{array}$ & $\begin{array}{l}\text { Soil exposure risks are } \\
\text { controlled for duration of risk }\end{array}$ \\
\hline \multicolumn{8}{|c|}{ Compliance with ARARs (threshold criterion) } \\
\hline \multicolumn{8}{|l|}{ Action-Specific } \\
\hline $\begin{array}{l}\text { National Emission Standards for } \\
\text { Hazardous Air Pollutants, } \\
\text { 40 CFR 61.93, "Emission } \\
\text { Monitoring and Test } \\
\text { Procedures" }\end{array}$ & $\begin{array}{l}\text { Would meet ARARs, } \\
\text { emissions would be below } \\
\text { allowable levels }\end{array}$ & $\begin{array}{l}\text { Would meet ARARs, } \\
\text { emissions would be below } \\
\text { allowable levels }\end{array}$ & $\begin{array}{l}\text { Would meet ARARs, } \\
\text { emissions would be below } \\
\text { allowable levels }\end{array}$ & $\begin{array}{l}\text { Would meet ARARs by } \\
\text { engineering and } \\
\text { administrative controls } \\
\text { implemented through the } \\
\text { RD/RA work plan } \\
\end{array}$ & $\begin{array}{l}\text { Would meet ARARs by } \\
\text { engineering and } \\
\text { administrative controls } \\
\text { implemented through the } \\
\text { RD/RA work plan }\end{array}$ & $\begin{array}{l}\text { Would meet ARARs by } \\
\text { engineering and } \\
\text { administrative controls } \\
\text { implemented through the } \\
\text { RD/RA work plan }\end{array}$ & $\begin{array}{l}\text { Would meet ARARs by } \\
\text { engineering and } \\
\text { administrative controls } \\
\text { implemented through the } \\
\text { RD/RA work plan }\end{array}$ \\
\hline $\begin{array}{l}\text { National Emission Standards for } \\
\text { Hazardous Air Pollutants, } \\
\text { 40 CFR 61.94(a), "Compliance } \\
\text { and Reporting" }\end{array}$ & $\begin{array}{l}\text { Would meet ARARs, } \\
\text { emissions would be below } \\
\text { allowable levels }\end{array}$ & $\begin{array}{l}\text { Would meet ARARs, } \\
\text { emissions would be below } \\
\text { allowable levels }\end{array}$ & $\begin{array}{l}\text { Would meet ARARs, } \\
\text { emissions would be below } \\
\text { allowable levels }\end{array}$ & $\begin{array}{l}\text { Would meet ARARs by } \\
\text { engineering and } \\
\text { administrative controls } \\
\text { implemented through the } \\
\text { RD/RA work plan } \\
\end{array}$ & $\begin{array}{l}\text { Would meet ARARs by } \\
\text { engineering and } \\
\text { administrative controls } \\
\text { implemented through the } \\
\text { RD/RA work plan }\end{array}$ & $\begin{array}{l}\text { Would meet ARARs by } \\
\text { engineering and } \\
\text { administrative controls } \\
\text { implemented through the } \\
\text { RD/RA work plan }\end{array}$ & $\begin{array}{l}\text { Would meet ARARs by } \\
\text { engineering and } \\
\text { administrative controls } \\
\text { implemented through the } \\
\text { RD/RA work plan }\end{array}$ \\
\hline $\begin{array}{l}\text { "Rules for Control of Fugitive } \\
\text { Dust," and "General Rules," } \\
\text { IDAPA } 58.01 .01 .650 \text { and } \\
\text { 58.01.01.651 }\end{array}$ & $\begin{array}{l}\text { Would meet ARARs, } \\
\text { emissions would be below } \\
\text { allowable levels }\end{array}$ & $\begin{array}{l}\text { Would meet ARARs, } \\
\text { emissions would be below } \\
\text { allowable levels }\end{array}$ & $\begin{array}{l}\text { Would meet ARARs, } \\
\text { emissions would be below } \\
\text { allowable levels }\end{array}$ & $\begin{array}{l}\text { Would meet ARARs by } \\
\text { engineering and } \\
\text { administrative controls } \\
\text { implemented through the } \\
\text { RD/RA work plan }\end{array}$ & $\begin{array}{l}\text { Would meet ARARs by } \\
\text { engineering and } \\
\text { administrative controls } \\
\text { implemented through the } \\
\text { RD/RA work plan }\end{array}$ & $\begin{array}{l}\text { Would meet ARARs by } \\
\text { engineering and } \\
\text { administrative controls } \\
\text { implemented through the } \\
\text { RD/RA work plan }\end{array}$ & $\begin{array}{l}\text { Would meet ARARs by } \\
\text { engineering and } \\
\text { administrative controls } \\
\text { implemented through the } \\
\text { RD/RA work plan }\end{array}$ \\
\hline $\begin{array}{l}\text { "Ground Water Quality Rule," } \\
\text { IDAPA 58.01.11 }\end{array}$ & Would not meet ARARs & Would meet ARARs by 2095 & Would meet ARARs by 2095 & Would meet ARARs by 2090 & Would meet ARARs by 2090 & Would meet ARARs by 2090 & Would meet ARARs by 2090 \\
\hline $\begin{array}{l}\text { "Rules and Minimum Standards } \\
\text { for the Construction and Use of } \\
\text { Injection Wells in the State of } \\
\text { Idaho," IDAPA } 37.03 .03\end{array}$ & Not applicable & $\begin{array}{l}\text { Would meet ARARs, shallow } \\
\text { injection wells impacted by } \\
\text { the remedy would be } \\
\text { abandoned, if necessary, in } \\
\text { accordance with the required } \\
\text { standards }\end{array}$ & $\begin{array}{l}\text { Would meet ARARs, shallow } \\
\text { injection wells impacted by } \\
\text { the remedy would be } \\
\text { abandoned, if necessary, in } \\
\text { accordance with the required } \\
\text { standards }\end{array}$ & $\begin{array}{l}\text { Would meet ARARs, shallow } \\
\text { injection wells impacted by } \\
\text { the remedy would be } \\
\text { abandoned, if necessary, in } \\
\text { accordance with the required } \\
\text { standards }\end{array}$ & $\begin{array}{l}\text { Would meet ARARs, shallow } \\
\text { injection wells impacted by } \\
\text { the remedy would be } \\
\text { abandoned, if necessary, in } \\
\text { accordance with the required } \\
\text { standards }\end{array}$ & $\begin{array}{l}\text { Would meet ARARs, shallow } \\
\text { injection wells impacted by } \\
\text { the remedy would be } \\
\text { abandoned, if necessary, in } \\
\text { accordance with the required } \\
\text { standards }\end{array}$ & $\begin{array}{l}\text { Would meet ARARs, shallow } \\
\text { injection wells impacted by } \\
\text { the remedy would be } \\
\text { abandoned, if necessary, in } \\
\text { accordance with the required } \\
\text { standards }\end{array}$ \\
\hline $\begin{array}{l}\text { "Well Construction Standards } \\
\text { Rules," IDAPA 37.03.09 }\end{array}$ & Not applicable & $\begin{array}{l}\text { Would meet ARARs, } \\
\text { boreholes or wells impacted } \\
\text { by the remedy would be } \\
\text { modified or abandoned, if } \\
\text { necessary, in accordance with } \\
\text { the required standards }\end{array}$ & $\begin{array}{l}\text { Would meet ARARs, } \\
\text { boreholes or wells impacted } \\
\text { by the remedy would be } \\
\text { modified or abandoned, if } \\
\text { necessary, in accordance with } \\
\text { the required standards }\end{array}$ & $\begin{array}{l}\text { Would meet ARARs, } \\
\text { boreholes or wells impacted } \\
\text { by the remedy would be } \\
\text { modified or abandoned, if } \\
\text { necessary, in accordance with } \\
\text { the required standards }\end{array}$ & $\begin{array}{l}\text { Would meet ARARs, } \\
\text { boreholes or wells impacted } \\
\text { by the remedy would be } \\
\text { modified or abandoned, if } \\
\text { necessary, in accordance with } \\
\text { the required standards }\end{array}$ & $\begin{array}{l}\text { Would meet ARARs, } \\
\text { boreholes or wells impacted } \\
\text { by the remedy would be } \\
\text { modified or abandoned, if } \\
\text { necessary, in accordance with } \\
\text { the required standards }\end{array}$ & $\begin{array}{l}\text { Would meet ARARs, } \\
\text { boreholes or wells impacted } \\
\text { by the remedy would be } \\
\text { modified or abandoned, if } \\
\text { necessary, in accordance with } \\
\text { the required standards }\end{array}$ \\
\hline $\begin{array}{l}\text { "Hazardous Waste } \\
\text { Determination," } 40 \text { CFR } 262.11\end{array}$ & Not applicable & 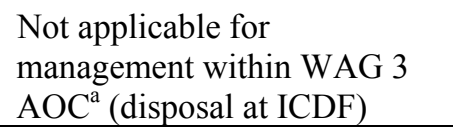 & $\begin{array}{l}\text { Not applicable for } \\
\text { management within WAG } 3 \\
\text { AOC (disposal at ICDF) }\end{array}$ & $\begin{array}{l}\text { Not applicable for } \\
\text { management within WAG } 3 \\
\text { AOC (disposal at ICDF) }\end{array}$ & $\begin{array}{l}\text { Not applicable for } \\
\text { management within WAG } 3 \\
\text { AOC (disposal at ICDF) }\end{array}$ & $\begin{array}{l}\text { Not applicable for } \\
\text { management within WAG } 3 \\
\text { AOC (disposal at ICDF) }\end{array}$ & $\begin{array}{l}\text { Not applicable for } \\
\text { management within WAG } 3 \\
\text { AOC (disposal at ICDF) }\end{array}$ \\
\hline
\end{tabular}




\begin{tabular}{|c|c|c|c|c|c|c|c|}
\hline \multirow[b]{2}{*}{ Criteria } & \multirow{2}{*}{$\begin{array}{l}\text { Alternative } 1 \\
\text { Limited Action }\end{array}$} & \multicolumn{2}{|c|}{$\begin{array}{c}\text { Alternative } 2 \\
\text { Containment and Monitoring }\end{array}$} & \multicolumn{2}{|c|}{$\begin{array}{c}\text { Alternative } 3 \\
\text { Hot Spot Removal, Containment, and Monitoring }\end{array}$} & \multicolumn{2}{|c|}{$\begin{array}{c}\text { Alternative } 4 \\
\text { Hot Spot Treatment, Containment, and Monitoring }\end{array}$} \\
\hline & & $2 \mathrm{a}$ & $2 \mathrm{~b}$ & $3 \mathrm{a}$ & $3 b$ & $4 \mathrm{a}$ & $4 \mathrm{~b}$ \\
\hline $\begin{array}{l}\text { "Temporary Units" IDAPA } \\
\text { 58.01.05.008 (40 CFR 264.553) }\end{array}$ & Not applicable & Not applicable & Not applicable & $\begin{array}{l}\text { Would meet ARARs by } \\
\text { engineering and } \\
\text { administrative controls } \\
\text { implemented through the } \\
\text { RD/RA work plan }\end{array}$ & $\begin{array}{l}\text { Would meet ARARs by } \\
\text { engineering and } \\
\text { administrative controls } \\
\text { implemented through the } \\
\text { RD/RA work plan }\end{array}$ & $\begin{array}{l}\text { Would meet ARARs by } \\
\text { engineering and } \\
\text { administrative controls } \\
\text { implemented through the } \\
\text { RD/RA work plan }\end{array}$ & $\begin{array}{l}\text { Would meet ARARs by } \\
\text { engineering and } \\
\text { administrative controls } \\
\text { implemented through the } \\
\text { RD/RA work plan }\end{array}$ \\
\hline $\begin{array}{l}\text { "Land Disposal Requirements" } \\
\text { IDAPA 58.01.05.011 } \\
(40 \text { CFR 268) }\end{array}$ & Not applicable & Not applicable & Not applicable & $\begin{array}{l}\text { Would meet ARARs by } \\
\text { characterization and treatment } \\
\text { if required }\end{array}$ & $\begin{array}{l}\text { Would meet ARARs by } \\
\text { characterization and treatment } \\
\text { if required }\end{array}$ & $\begin{array}{l}\text { Would meet ARARs by } \\
\text { characterization and treatment } \\
\text { if required }\end{array}$ & $\begin{array}{l}\text { Would meet ARARs by } \\
\text { characterization and treatment } \\
\text { if required }\end{array}$ \\
\hline $\begin{array}{l}\text { "Alternative LDR Treatment } \\
\text { Standards for Contaminated } \\
\text { Soil" IDAPA 58.01.05.011 } \\
\text { (40 CFR 268.49) }\end{array}$ & Not applicable & Not applicable & Not applicable & $\begin{array}{l}\text { Would meet ARARs by } \\
\text { characterization and treatment } \\
\text { if required }\end{array}$ & $\begin{array}{l}\text { Would meet ARARs by } \\
\text { characterization and treatment } \\
\text { if required }\end{array}$ & $\begin{array}{l}\text { Would meet ARARs by } \\
\text { characterization and treatment } \\
\text { if required }\end{array}$ & $\begin{array}{l}\text { Would meet ARARs by } \\
\text { characterization and treatment } \\
\text { if required }\end{array}$ \\
\hline \multicolumn{8}{|l|}{ Chemical-Specific } \\
\hline $\begin{array}{l}\text { "Toxic Substances," } \\
\text { IDAPA 58.01.01.161 } \\
\text { "Toxic Air Pollutants, } \\
\text { Noncarcinogenic Increments," } \\
\text { IDAPA 58.01.01.585 } \\
\text { "Toxic Air Pollutants, } \\
\text { Carcinogenic Increments," } \\
\text { IDAPA 58.01.01.586 } \\
\text { "Environmental Remediation } \\
\text { Source," } \\
\text { IDAPA 58.01.01.210.16(a) }\end{array}$ & $\begin{array}{l}\text { Would meet ARARs, } \\
\text { emissions would be below } \\
\text { allowable levels }\end{array}$ & $\begin{array}{l}\text { Would meet ARARs by } \\
\text { engineering and } \\
\text { administrative controls } \\
\text { implemented through the } \\
\text { RD/RA work plan }\end{array}$ & $\begin{array}{l}\text { Would meet ARARs by } \\
\text { engineering and } \\
\text { administrative controls } \\
\text { implemented through the } \\
\text { RD/RA work plan }\end{array}$ & $\begin{array}{l}\text { Would meet ARARs by } \\
\text { engineering and } \\
\text { administrative controls } \\
\text { implemented through the } \\
\text { RD/RA work plan }\end{array}$ & $\begin{array}{l}\text { Would meet ARARs by } \\
\text { engineering and } \\
\text { administrative controls } \\
\text { implemented through the } \\
\text { RD/RA work plan }\end{array}$ & $\begin{array}{l}\text { Would meet ARARs by } \\
\text { engineering and } \\
\text { administrative controls } \\
\text { implemented through the } \\
\text { RD/RA work plan }\end{array}$ & $\begin{array}{l}\text { Would meet ARARs by } \\
\text { engineering and } \\
\text { administrative controls } \\
\text { implemented through the } \\
\text { RD/RA work plan }\end{array}$ \\
\hline $\begin{array}{l}\text { "Ambient Air Quality Standards } \\
\text { For Specific Air Pollutants," } \\
\text { IDAPA 58.01.01.577 }\end{array}$ & $\begin{array}{l}\text { Would meet ARARs, } \\
\text { emissions would be below } \\
\text { allowable levels }\end{array}$ & Would meet ARARs & Would meet ARARs & Would meet ARARs & Would meet ARARs & Would meet ARARs & Would meet ARARs \\
\hline $\begin{array}{l}\text { National Emission Standards for } \\
\text { Hazardous Air Pollutants, } \\
\text { 40 CFR 61.92, "Standard" }\end{array}$ & $\begin{array}{l}\text { Would meet ARARs, } \\
\text { emissions would be below } \\
\text { allowable levels }\end{array}$ & $\begin{array}{l}\text { Would meet ARARs, } \\
\text { emissions would be below } \\
\text { allowable levels }\end{array}$ & $\begin{array}{l}\text { Would meet ARARs, } \\
\text { emissions would be below } \\
\text { allowable levels }\end{array}$ & $\begin{array}{l}\text { Would meet ARARs by } \\
\text { administrative and } \\
\text { engineering controls }\end{array}$ & $\begin{array}{l}\text { Would meet ARARs by } \\
\text { administrative and } \\
\text { engineering controls }\end{array}$ & $\begin{array}{l}\text { Would meet ARARs by } \\
\text { administrative and } \\
\text { engineering controls }\end{array}$ & $\begin{array}{l}\text { Would meet ARARs by } \\
\text { administrative and } \\
\text { engineering controls }\end{array}$ \\
\hline \multicolumn{8}{|l|}{ Location-Specific (none identified) } \\
\hline $\begin{array}{l}\text { Long-term effectiveness and } \\
\text { permanence (balancing } \\
\text { criterion) }\end{array}$ & $\begin{array}{l}\text { No long-term effectiveness or } \\
\text { permanence }\end{array}$ & $\begin{array}{l}\text { Provides long-term } \\
\text { effectiveness and permanence } \\
\text { for duration of risk by capping } \\
\text { contaminated soil. MCLs are } \\
\text { attained in SRPA in } 2095 \text { and } \\
\text { after. }\end{array}$ & $\begin{array}{l}\text { Provides long-term } \\
\text { effectiveness and permanence } \\
\text { for duration of risk by capping } \\
\text { contaminated soil. MCLs are } \\
\text { attained in SRPA in } 2095 \text { and } \\
\text { after. }\end{array}$ & $\begin{array}{l}\text { Provides long-term } \\
\text { effectiveness and permanence } \\
\text { for duration of risk by capping } \\
\text { contaminated soil (removing } \\
\text { hot spot does not reduce risk). } \\
\text { MCLs are attained in SRPA in } \\
2090 \text { and after. }\end{array}$ & $\begin{array}{l}\text { Provides long-term } \\
\text { effectiveness and permanence } \\
\text { for duration of risk by capping } \\
\text { contaminated soil (removing } \\
\text { hot spot does not reduce risk). } \\
\text { MCLs are attained in SRPA in } \\
2090 \text { and after. }\end{array}$ & $\begin{array}{l}\text { Provides long-term } \\
\text { effectiveness and permanence } \\
\text { for duration of risk by capping } \\
\text { contaminated soil (grouting } \\
\text { hot spot does not reduce risk). } \\
\text { MCLs are attained in SRPA in } \\
2090 \text { and after. }\end{array}$ & $\begin{array}{l}\text { Provides long-term } \\
\text { effectiveness and permanence } \\
\text { for duration of risk by capping } \\
\text { contaminated soil (grouting } \\
\text { hot spot does not reduce risk). } \\
\text { MCLs are attained in SRPA in } \\
2090 \text { and after. }\end{array}$ \\
\hline $\begin{array}{l}\text { Reduction of toxicity, mobility, } \\
\text { or volume through treatment } \\
\text { (balancing criterion) }\end{array}$ & $\begin{array}{l}\text { Provides no treatment except } \\
\text { radioactive decay }\end{array}$ & $\begin{array}{l}\text { Provides no treatment except } \\
\text { radioactive decay }\end{array}$ & $\begin{array}{l}\text { Provides no treatment except } \\
\text { radioactive decay }\end{array}$ & $\begin{array}{l}\text { Provides no treatment except } \\
\text { radioactive decay }\end{array}$ & $\begin{array}{l}\text { Provides no treatment except } \\
\text { radioactive decay }\end{array}$ & $\begin{array}{l}\text { In situ grouting would } \\
\text { immobilize a fraction of the } \\
\text { Sr-90 remaining in soil inside } \\
\text { tank farm boundary }\end{array}$ & $\begin{array}{l}\text { In situ grouting would } \\
\text { immobilize a fraction of the } \\
\text { Sr-90 remaining in soil inside } \\
\text { tank farm boundary }\end{array}$ \\
\hline
\end{tabular}


Table 11-1. (continued).

\begin{tabular}{|c|c|c|c|c|c|c|c|}
\hline \multirow[b]{2}{*}{ Criteria } & \multirow{2}{*}{$\begin{array}{l}\text { Alternative } 1 \\
\text { Limited Action }\end{array}$} & \multicolumn{2}{|c|}{$\begin{array}{c}\text { Alternative } 2 \\
\text { Containment and Monitoring }\end{array}$} & \multicolumn{2}{|c|}{$\begin{array}{c}\text { Alternative } 3 \\
\text { Hot Spot Removal, Containment, and Monitoring }\end{array}$} & \multicolumn{2}{|c|}{$\begin{array}{c}\text { Alternative } 4 \\
\text { Hot Spot Treatment, Containment, and Monitoring }\end{array}$} \\
\hline & & $2 \mathrm{a}$ & $2 \mathrm{~b}$ & $3 a$ & $3 b$ & $4 \mathrm{a}$ & $4 \mathrm{~b}$ \\
\hline $\begin{array}{l}\text { Short-term effectiveness } \\
\text { (balancing criterion) }\end{array}$ & $\begin{array}{l}\text { Highly effective. Risks are } \\
\text { eliminated during IC period }\end{array}$ & $\begin{array}{l}\text { No risks to outlying } \\
\text { communities or environment. } \\
\text { Risks to workers during } \\
\text { remedy implementation would } \\
\text { be reduced to allowable levels } \\
\text { by engineering and } \\
\text { administrative controls }\end{array}$ & $\begin{array}{l}\text { No risks to outlying } \\
\text { communities or environment. } \\
\text { Risks to workers during } \\
\text { remedy implementation would } \\
\text { be reduced to allowable levels } \\
\text { by engineering and } \\
\text { administrative controls }\end{array}$ & $\begin{array}{l}\text { No risks to outlying } \\
\text { communities or environment. } \\
\text { CPP- } 31 \text { removal remedy has } \\
\text { lowest short-term } \\
\text { effectiveness, highest risks of } \\
\text { worker exposures during } \\
\text { remedy implementation }\end{array}$ & $\begin{array}{l}\text { No risks to outlying } \\
\text { communities or environment. } \\
\text { CPP-31 removal remedy has } \\
\text { lowest short-term } \\
\text { effectiveness, highest risks of } \\
\text { worker exposures during } \\
\text { remedy implementation } \\
\end{array}$ & $\begin{array}{l}\text { No risks to outlying } \\
\text { communities or environment. } \\
\text { CPP-31 in situ grouting has } \\
\text { lower risks of worker } \\
\text { exposures during remedy } \\
\text { implementation than } \\
\text { excavating soil } \\
\end{array}$ & $\begin{array}{l}\text { No risks to outlying } \\
\text { communities or environment. } \\
\text { CPP-31 in situ grouting has } \\
\text { lower risks of worker } \\
\text { exposures during remedy } \\
\text { implementation than } \\
\text { excavating soil }\end{array}$ \\
\hline $\begin{array}{l}\text { Implementability (balancing } \\
\text { criterion) }\end{array}$ & $\begin{array}{l}\text { Readily implemented because } \\
\text { it only involves continuing } \\
\text { existing ICs }\end{array}$ & $\begin{array}{l}\text { Technically complex due to } \\
\text { required infrastructure } \\
\text { modifications and extent of } \\
\text { low-permeability pavement }\end{array}$ & $\begin{array}{l}\text { Less technically complex than } \\
\text { Alternative 2a since less } \\
\text { infrastructure modification } \\
\text { required as part of remedy }\end{array}$ & $\begin{array}{l}\text { Very technically complex due } \\
\text { to required infrastructure } \\
\text { modifications, remote } \\
\text { retrieval of large fraction of } \\
\text { CPP-31 soil, and extent of } \\
\text { infiltration-reduction capping. } \\
\text { CPP-31 removal is moderately } \\
\text { implementable. Limited } \\
\text { commercial availability of } \\
\text { remote excavation services }\end{array}$ & $\begin{array}{l}\text { Less technically complex than } \\
\text { Alternative 3a since less } \\
\text { infrastructure modification } \\
\text { would be required as part of } \\
\text { remedy }\end{array}$ & $\begin{array}{l}\text { Very technically complex due } \\
\text { to required infrastructure } \\
\text { modification and extent of } \\
\text { low-permeability pavement. } \\
\text { CPP-31 in situ grouting is } \\
\text { technically complex due to } \\
\text { subsurface infrastructure, } \\
\text { difficulty in monitoring } \\
\text { effectiveness. Commercial jet } \\
\text { grouting services are } \\
\text { available. }\end{array}$ & $\begin{array}{l}\text { Less technically complex than } \\
\text { Alternative 4a since less } \\
\text { infrastructure modification } \\
\text { would be required as part of } \\
\text { remedy }\end{array}$ \\
\hline \multicolumn{8}{|c|}{ Cost (million) (net present value in Fiscal Year [FY] 2006 dollars) (balancing criterion) } \\
\hline Capital cost & $\$ 0$ & $\$ 6.9$ & $\$ 3.7$ & $\$ 37.8$ & $\$ 22.2$ & $\$ 10.8$ & $\$ 6.0$ \\
\hline $\begin{array}{l}\text { Operating and maintenance } \\
\text { cost }\end{array}$ & $\$ 3.3$ & $\$ 5.3$ & $\$ 5.3$ & $\$ 5.3$ & $\$ 5.3$ & $\$ 5.3$ & $\$ 5.3$ \\
\hline Total cost & $\$ 3.3$ & $\$ 12.2$ & $\$ 9.0$ & $\$ 43.1$ & $\$ 27.5$ & $\$ 16.1$ & $\$ 11.3$ \\
\hline
\end{tabular}


site. Relevant and appropriate requirements are those cleanup standards, standards of control, and other substantive requirements, criteria, or limitations promulgated under federal environmental or state environmental or facility siting laws that, while not "applicable" to a hazardous substance, pollutant, contaminant, remedial action, location, or other circumstance at a CERCLA site, address problems or situations sufficiently similar to those encountered at the CERCLA site that their use is well-suited to the particular site.

A summary discussion of compliance with ARARs is provided in Table 11-1. Alternative 1 would meet all Clean Air Act (42 USC 7401 et seq.) and Idaho air regulations identified in Table 11-1 by implementing ICs and monitoring through administrative controls. Alternative 1 would not meet MCLs after 2095 because Sr-90 concentrations in the SRPA would exceed standards.

Alternatives 2a, 2b, 3a, 3b, 4a, and 4b would meet soil removal and disposal ARARs identified in this section. Clean Air Act and Idaho air regulations would be met during remediation activities through administrative and engineering controls. Administrative and engineering controls would be implemented during soil excavation and cap construction to limit radiological doses in accordance with DOE Order 5400.5, "Radiation Protection of the Public and the Environment." Completing final remedy implementation by 2012, as for Alternatives 2a, 3a, and 4a, versus completing phased-remedy implementation by 2035, as for Alternatives $2 \mathrm{~b}, 3 \mathrm{~b}$, and $4 \mathrm{~b}$, would have no effect on attainment of ARARs. Alternatives 2a, 2b, 3a, 3b, 4a, and 4b would meet MCLs by 2095 based on groundwater modeling predictions.

\subsection{Long-Term Effectiveness and Permanence}

This criterion refers to expected residual risk and the ability of a remedy to maintain reliable protection of human health and the environment over time, after cleanup levels have been met. This criterion includes consideration of residual risk that will remain onsite following remediation and the adequacy and reliability of controls.

Alternative 1 would provide no long-term effectiveness or permanence because no physical controls would be implemented, other than the TFIA asphalt surfaces, drainage system, and evaporation pond. The TFIA asphalt surfaces are assumed to require relatively frequent repair and sealing and to not limit infiltration into CPP-31 soil after 2095. The surface water controls would not be effective after 2095. The existing asphalt surface covering would not provide an adequate surface barrier to prevent exposures to future workers after 2095.

Alternatives 2 through 4 had medium long-term effectiveness and permanence. This criterion applies to the soil and the SRPA. The long-term worker exposure to the soil is controlled by the ET/CB and/or administrative controls, which are the same for each of these alternatives. Alternatives 2 through 4 also result in roughly equivalent long-term effectiveness and permanence for the SRPA. Removing (Alternative 3) or grouting (Alternative 4) CPP-31 soil was predicted by modeling to have only a slight effect on Sr-90 concentrations in the SRPA. Thus, recharge control by low-permeability pavement, implemented under Alternatives 2, 3, and 4, would provide adequate long-term effectiveness and permanence for the soil and for the SRPA until the MCL for Sr-90 is met, which is predicted to be by 2095. All alternatives include groundwater monitoring for OU 3-14 contaminants to ensure MCLs will be met in the SRPA beneath INTEC by 2095. 


\subsection{Reduction of Toxicity, Mobility, and Volume through Treatment}

This criterion considers the expected performance of treatment technologies that may be included as part of a remedy. Alternative 1 would not implement treatment and would not reduce Cs-137 or Sr-90 toxicity, mobility, or volume except through natural radioactive decay. Alternatives $4 \mathrm{a}$ and $4 \mathrm{~b}$ would implement treatment through in situ grouting at CPP-31, thereby reducing mobility of most of the Sr-90 present in soil at OU 3-14.

Alternatives 2a, 2b, 3a, and 3b would not use treatment. However, mobility of Sr-90 would be lowered by reducing the infiltration that drives downward migration from contaminated perched water to the SRPA.

\subsection{Short-Term Effectiveness}

The period of time needed to implement the remedy and any adverse effects that may be posed to workers, the public, and the environment during construction and operation of the remedy until cleanup levels are achieved are included in this criterion. No added risks to the public or the environment would result from implementing any of the alternatives; therefore, only worker risks during remedy implementation are discussed.

Alternative 1 has the best short-term effectiveness, because existing ICs, TFIA O\&M, and monitoring could be continued with no added risks or hazards to workers. Soil removal and cap construction implemented as part of Alternatives $2 \mathrm{a}, 2 \mathrm{~b}, 3 \mathrm{a}, 3 \mathrm{~b}, 4 \mathrm{a}$, and $4 \mathrm{~b}$ would have incrementally higher risks to workers, but they could be mitigated by INL Site work controls and physical controls.

Short-term effectiveness for Alternative $2 \mathrm{~b}$ would be essentially the same as for Alternative 2a. Construction of a low-permeability pavement on the central tank farm as part of phased remedy implementation would not increase risks to workers, the public, or the environment.

Alternatives $4 \mathrm{a}$ and $4 \mathrm{~b}$ would have increased chances of worker exposures and injuries due to production of radioactive drill cuttings and grout returns. Mitigating risks and hazards would require significant administrative and engineering controls. Gamma radiation exposures from drill cuttings and grout returns under Alternative $4 \mathrm{~b}$ would be lower than for Alternative $4 \mathrm{a}$ because an additional 23 years of radioactive decay of Cs-137 would reduce gamma radiation levels.

Alternatives $3 \mathrm{a}$ and $3 \mathrm{~b}$ would likely have the highest worker direct radiation exposures and would require more substantive administrative and engineering controls, including shielding and a work enclosure. Even if all worker exposures were controlled to facility limits by using shielding, reducing exposure times, and increasing the numbers of workers, the total occupational exposures would be higher for Alternatives $3 a$ and $3 b$ than for any other alternative due to removal of CPP-31 soil. Exposures under Alternative $3 \mathrm{~b}$ would be somewhat lower than for Alternative 3a because an additional 23 years of radioactive decay of Cs-137 would reduce gamma radiation levels.

\subsection{Implementability}

Implementability addresses the technical and administrative feasibility of a remedy from design through construction and operation. Factors such as availability of services and materials, administrative feasibility, and coordination with other governmental entities are considered. 
Alternative 1 would be the most readily implementable alternative because it only involves continuing existing ICs, TFIA O\&M, and monitoring. Covering the RCZ with low-permeability pavement is technically implementable; however, achieving the required positive drainage over the entire area would require regrading in some areas as well as additional lined drainage ditches and potentially at least one additional lift station.

Capping the central tank farm with an ET/CB after TFF closure, as for Alternatives 2a, 3a, and 4a, is technically complex, because of the interfering infrastructure. Decontamination and decommissioning of existing buildings and construction of retaining walls as part of remedy implementation would greatly reduce the technical implementability of these alternatives. Capping the central tank farm with an ET/CB after INTEC closure, as for Alternatives $2 \mathrm{~b}, 3 \mathrm{~b}$, and $4 \mathrm{~b}$, is much more feasible, because interfering infrastructure would have been removed by the decontamination and decommissioning program prior to capping.

Alternative $2 \mathrm{~b}$ is the only viable alternative (Alternative 1 does not meet threshold criteria) that is highly implementable. Capping would not require digging or drilling into the hot spot, and the final ET/CB would be constructed in the central tank farm when INTEC operations have ended and interfering infrastructure has been removed.

CPP-31 soil removal (Alternatives $3 \mathrm{a}$ and $3 \mathrm{~b}$ ) has relatively low implementability. This is because of the high direct radiation exposures that would be encountered, which would require remote retrieval (no worker contact) inside an enclosure and specialized equipment and services with limited availability, as well as the required depth of retrieval (up to $40 \mathrm{ft}$ ), which would require shoring and access ramps. Alternative $3 \mathrm{~b}$ is more technically feasible than Alternative $3 \mathrm{a}$, because interfering infrastructure would be reduced by the end of INTEC activities.

In situ grouting (Alternatives $4 \mathrm{a}$ and $4 \mathrm{~b}$ ) also has relatively low implementability due to the extensive subsurface infrastructure, potential for worker exposures and injury, and requirements for specialized equipment and services that have limited availability. Alternative 4a has low implementability because of (1) the combined complexity of drilling into the hot spot with existing INTEC infrastructure still operating and (2) capping the central tank farm with an ET/CB up to $18 \mathrm{ft}$ thick adjacent to an active building and over active waste lines and valve boxes. Alternative $4 \mathrm{~b}$ is more technically feasible than Alternative $4 \mathrm{a}$ because interfering infrastructure would be reduced by the end of INTEC activities.

\subsection{Cost}

Total project costs, in net present value, are listed in Table 11-1. Detailed cost estimates are included in the OU 3-14 Tank Farm Soil and Groundwater Feasibility Study (DOE-ID 2006d), Appendix B, and are presented in present day dollar values.

\subsection{State Acceptance}

DEQ has been involved in the development and review of all aspects of this project, including the documents in the Administrative Record and this ROD. All comments received from DEQ on these documents have been resolved and the documents revised accordingly. In addition, DEQ has participated in public meetings where public comments and concerns have been received and discussed. DEQ concurs with the selected remedial alternative for the tank farm soil and INTEC groundwater contained in this ROD and is a signatory to the ROD with DOE and EPA. 


\subsection{Community Acceptance}

Community participation in the remedy selection process and Proposed Plan reviews included participation in the public meetings held August 29 and 30, 2006. The 30-day public comment period was extended an additional 30 days, from August 22, 2006, through October 21, 2006. The Responsiveness Summary, presented as Part 3 of this ROD, includes verbal and written comments received from the public with the corresponding Agencies' responses to these comments. The public provided a broad range of comments, ranging from acceptance of the preferred alternative to requesting removal of all contaminants. 


\section{SELECTED REMEDY}

The selected remedy for OU 3-14 soil and groundwater is Alternative 2b-ICs, monitoring, soil excavation and disposal as necessary, containment (low-permeability pavement and ET/CB) - along with additional infiltration controls. The selected remedy will reduce toxicity by reducing contaminant migration to the SRPA sufficiently to attain MCLs beneath INTEC by 2095 , reduce potential gamma radiation exposures to current and future workers and biota to allowable levels, and prevent biotic intrusion.

\subsection{Summary of the Rationale for the Selected Remedy}

The selected remedy is protective of human health and the environment, complies with all federal and state ARARs, meets all of the RAOs, and maintains long-term protectiveness and permanence. This alternative was selected over the other alternatives because it

- Is highly implementable - The remedy is highly implementable because it takes into account interfering infrastructure and activities of other INTEC cleanup projects. The ET/CB can be constructed in a single phase over an inactive surface rather than constructing a cap with aboveground structures protruding through it and patching as the structures are removed.

- $\quad$ Provides higher short-term effectiveness - The remedy poses less short-term risk to workers during implementation because remote handling of waste or complex excavations or enclosures are not needed, and it has less risk of exposure to contaminated soil from excavation or grout returns.

- Is the most cost-effective-The remedy is fully protective of workers and the SRPA and the least costly. The other alternatives cost significantly more but do not achieve a significant decrease in risks or restoration timeframe.

Due to practical limitations for achieving an infiltration rate of $1 \mathrm{~mm} / \mathrm{yr}$ in the middle of an operating facility, the Agencies will implement additional recharge controls within a larger area over the northern perched water. Potential actions to reduce water infiltration and recharge of the perched water zones beneath the northern portion of INTEC were identified in "Methods to Reduce Water Infiltration and Recharge of the Northern Shallow Perched Water Zone at INTEC" (EDF-6868). The actions include eliminating unnecessary discharges of clean water to the ground, improving the storm water drainage system, and monitoring process meter flows so that leaks can be detected and fixed. These actions will be implemented under OU 3-14 and defined during remedial design.

\subsection{Description of the Selected Remedy}

The selected remedy for OU 3-14 consists of remedial actions for tank farm soil and groundwater contaminated by INTEC releases, no action for a group of sites outside the tank farm, and potential actions for any newly discovered sites assigned to OU 3-14 under the new site identification process. The OU 3-14 remedy supersedes the OU 3-13 interim actions and is integrated with the OU 3-13 final actions. The selected remedy details are described below. A summary of component installation timing is presented in Table 12-1. Note that the timing of the selected remedy is slightly different from Alternative $2 b$. 
Table 12-1. Installation timing for the selected remedy.

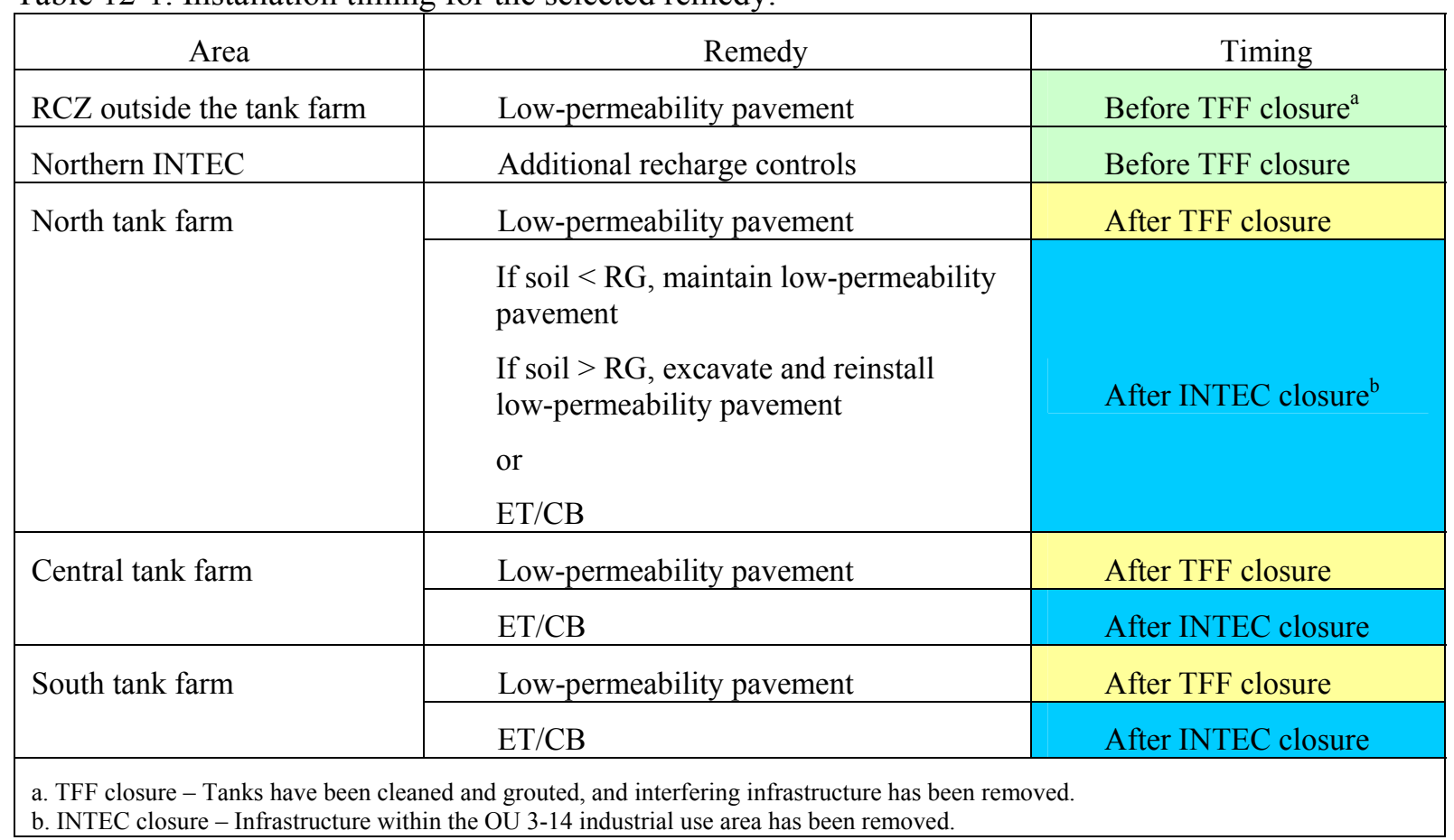

\subsubsection{Components of the Selected Remedy Prior to Tank Farm Facility Closure}

The components of the selected remedy to begin prior to TFF closure include the following (engineering detail and performance criteria will be provided in the OU 3-14 RD/RA work plan, which follows signature of this ROD):

- Implement ICs for the INTEC groundwater that exceeds MCLs, the contaminated tank farm soil, and the area in proximity to the tank farm designated for industrial land use (see Figure 4-2). Section 12.2.4 identifies the type of controls that will be implemented. These ICs will be implemented as part of the remedy and included in the INL Sitewide Institutional Controls Plan (DOE-ID 2006c or subsequent revisions). This supports RAOs I, III, and IV.

- Install and maintain a low-permeability pavement (or equivalent barrier to reduce infiltration) over the RCZ outside the tank farm (see bottom left drawing of Figure 10-4) with an expanded drainage system to reduce infiltration of precipitation without interfering with ongoing INTEC operations and remediation activities. Installation will be performed in sections as geographical areas become available. The low-permeability pavement will be designed to abut existing buildings and structures as practical to minimize (to the extent possible) surface water infiltration. As buildings and structures are removed through DD\&D, the low-permeability pavement will be extended to maintain an infiltration-reducing barrier over the RCZ outside the tank farm. Water run-off will be directed toward lined ditches (i.e., concrete-lined TFIA ditches) (see Figure 10-2), which will divert it to an evaporation pond. The goal will be to capture and send to the evaporation pond an equivalent volume of infiltration that would fall on the RCZ outside the tank farm. Operations and maintenance details will be specified in the OU 3-14 RD/RA work plan. This supports RAO II. 
- $\quad$ Maintain the TFIA system per the O\&M Plan (DOE-ID 2006e) until the system is incorporated into, and expanded to accommodate, the drainage and water management requirements of the selected remedy. Approval of the OU 3-14 RD/RA work plan with its O\&M plan, and expansion, completes the TFIA. This supports RAOs II and V.

- Implement and maintain additional recharge controls in northern INTEC to reduce anthropogenic and storm water recharge sources to the northern perched water zones. Actions will include such activities as capturing roof run-off from area buildings, eliminating excessive landscape watering, eliminating steam condensate drip-leg discharges, lining drainage ditches and improving INTEC drainage, and extending pavement to reduce water infiltration. Water run-off will be directed toward lined ditches (i.e., concrete-lined TFIA ditches), which will divert it to the evaporation pond. Other actions will be designed to detect anthropogenic recharge and will include pipeline valve isolation tests and hydrostatic tests to identify leaks in suspect areas, calculating water balances to identify changes in system flows that could indicate leaks, installing additional flow meters to improve the accuracy of water balances, and expanding the telemetry for real-time water level monitoring in perched water wells to detect subsurface leaks. This supports RAO II.

- Monitor contaminant concentrations and water levels in indicator monitoring wells to determine the effectiveness of the groundwater remedy. Monitor perched water and groundwater in the SRPA to ensure that the portions of the SRPA contaminated by INTEC sources will meet MCLs by 2095. Monitoring of perched water and the SRPA under the OU 3-13 ROD (DOE-ID 1999a) will be superseded by a long-term monitoring plan for OU 3-14. In the interim, Group 4 (perched water) and Group 5 (SRPA) will continue to follow the OU 3-13 monitoring plans (DOE-ID 2005, 2004d, respectively). This supports RAOs I and II.

\subsubsection{Remedy Components following Tank Farm Facility Closure}

Components of the selected remedy to be installed or maintained after TFF closure (tanks grouted and interfering infrastructure removed) include

- Install a low-permeability pavement (or equivalent barrier to reduce infiltration) over the north, central, and south tank farm to reduce infiltration of precipitation (see bottom left drawing of Figure 10-4). The low-permeability pavement will be designed to abut existing buildings, structures, or retaining walls (as practical) to ensure maximum capture of precipitation. Captured surface water run-off will be directed toward lined ditches, culverts, and lift station(s) for transport to the lined evaporation pond. This supports RAO II.

- $\quad$ Continue ICs for the INTEC groundwater that exceeds MCLs, the contaminated tank farm soil, and the area in proximity to the tank farm designated for industrial land use (Figure 4-2). Section 12.2.4 identifies the type of controls. These ICs will be included in the INL Sitewide Institutional Controls Plan (DOE-ID 2006c or subsequent revisions). This supports RAOs I, III, and IV.

- $\quad$ Maintain the drainage system and low-permeability pavement over the RCZ (see Figure 4-1) to reduce infiltration of precipitation without interfering with ongoing INTEC cleanup operations. As buildings and structures are removed through DD\&D, the low-permeability pavement will be extended to maintain an infiltration-reducing barrier over the RCZ. Surface water run-off will be directed toward lined ditches (i.e., concrete-lined ditches) (see Figure 10-2), which will divert it to the lined evaporation pond. Operations and maintenance details will be specified in the OU 3-14 RD/RA work plan. This supports RAO II. 
- Maintain the recharge controls in northern INTEC to reduce anthropogenic and storm water recharge sources to the northern perched water zones. Actions will include the maintenance of activities that captured roof run-off from area buildings, lined drainage ditches and INTEC drainage, and pavement to reduce water infiltration. Water run-off will be directed toward lined ditches (i.e., concrete-lined ditches), which will divert it to the lined evaporation pond. Actions will continue that were designed to detect anthropogenic recharge, which include performing pipeline valve isolation tests and hydrostatic tests to identify leaks in suspect areas, calculating water balances to identify changes in system flows that could indicate leaks, installing additional flow meters to improve the accuracy of water balances, and installing telemetry for real-time water level monitoring in perched water wells to detect subsurface leaks. This supports RAO II.

- Monitor contaminant concentrations and water levels in indicator monitoring wells to determine the effectiveness of the groundwater remedy. Monitor perched water and the SRPA in accordance with a long-term monitoring plan to ensure that the portions of the SRPA contaminated by INTEC sources will meet MCLs by 2095. This supports RAOs I and II.

\subsubsection{Remedy Components Coordinated with INTEC Facility Closure}

INTEC facility closure is defined as when the active infrastructures, as shown in Figure 4-1, reach their final end state. Components of the selected remedy to be installed or maintained after INTEC closure include the following:

- Install a protective cover over the north tank farm (see Figure 10-1). Characterization results will be used to design the protective cover (e.g., maintain the low-permeability pavement, excavate soil and replace with clean backfill and new low-permeability pavement or equivalent barrier to reduce infiltration, or extend the ET/CB that is placed over the central area). This supports RAOs II, III, and $\mathrm{V}$.

- Install an ET/CB over the central and south tank farm to protect workers from exposure (see Figure 10-3). The ET/CB will be installed in a single action after interfering infrastructure is removed. Native vegetation will be planted on the cover to minimize erosion and infiltration of precipitation. The upper layers of the ET/CB will contain topsoil and fine-grained soil to store water and promote plant growth; the lower section will consist of compacted fill that will be used to shape the crowned surface and isolate contaminated soil from current and future workers and biota. Between the two sections will be a biointrusion and capillary barrier that will prevent both water and biota from entering the compacted fill. This supports RAOs II, III, and V.

- Monitor and maintain the ET/CB, low-permeability pavement, and drainage system to reduce infiltration of precipitation. This supports RAOs II, III, and V.

- Continue ICs for the INTEC groundwater that exceeds MCLs, the contaminated tank farm soil, and the area in proximity to the tank farm designated for industrial land use (Figure 4-2). Section 12.2.4 identifies the type of controls. These ICs will be included in the INL Sitewide Institutional Controls Plan (DOE-ID 2006c or subsequent revisions). This supports RAOs I, III, and IV.

- Monitor contaminant concentrations and water levels in indicator monitoring wells to determine the effectiveness of the groundwater remedy. Monitor perched water and the SRPA in accordance with a long-term monitoring plan to ensure that the portions of the SRPA contaminated by INTEC sources will meet MCLs by 2095. This supports RAOs I and II. 


\subsubsection{Institutional Controls Component of the Selected Remedy}

Institutional controls are used to prevent unacceptable exposure to contamination remaining at a site. This is accomplished through the use of administrative, physical, and legal controls and access restrictions. The remedy for tank farm soil and INTEC groundwater includes actions to isolate contaminants and prevent unacceptable exposure pathways through engineered controls. To ensure success of the remedy, ICs will be used to prevent unacceptable exposure to the contaminated soil and groundwater in addition to preventing land uses that would be inconsistent with the selected remedy. These controls include the designation of the land use in the proximity of the tank farm as industrial (Figure 4-2) and a groundwater and drilling IC area (Figure 5-6). The institutional controls will be maintained until the concentration of hazardous substances in the soil and groundwater is at levels that would allow for unlimited use and unrestricted exposure.

Institutional controls will be implemented to prevent unacceptable exposure to contaminated soil or groundwater. The process to control disturbances of CERCLA sites as documented in the INL Sitewide Institutional Controls Plan (DOE-ID 2006c) will be updated to manage disturbances of contaminated tank farm soil by non-CERCLA activities, including ensuring that intrusions in the ET/CB cap are repaired properly and in a timely manner. To prevent use of contaminated groundwater, restrictions will be implemented for the portion of the SRPA in proximity to INTEC that exceeds MCLs. Administrative controls will also be necessary to prevent cross contamination between contaminated perched water and the SRPA from drilling activities. Figure 5-6 identifies the initial area that will have restrictions associated with drilling and prohibitions on water use for drinking or irrigation purposes if the boring will encounter perched water and/or the SRPA. The boundary of this controlled area is based on sampling data and has been conservatively estimated to include those areas where groundwater could be expected to approach or exceed the MCLs for Sr-90, Tc-99, I-129, and nitrate. Through the use of the ongoing review process for the IC plan and the CERCLA 5-year reviews, this boundary will be adjusted, as necessary, to ensure that the areas where groundwater exceeds MCLs due to INTEC releases are included in this restricted area. In the future when the sampling results and trends identify that the groundwater meets MCLs and is acceptable for unrestricted use, the boundary will be adjusted until such time as the ICs associated with the groundwater restrictions are eliminated. The predicted timeframe for the portion of the SRPA contaminated by INTEC releases to meet the MCLs is on or before 2095.

DOE is responsible for implementing, maintaining, reporting on, and enforcing the ICs, including land use controls that are required under this ROD. Although DOE may later transfer these procedural responsibilities to another party, by contract, property transfer agreement, or through other means, DOE shall retain ultimate responsibility for remedy integrity. The current implementation, maintenance, and periodic inspection requirements for the ICs at the INL Site are described in the approved CERCLA work plans, which include operation and maintenance plans and the INL Sitewide Institutional Controls Plan (DOE-ID 2006c).

\subsubsection{Revision to the INL Sitewide Institutional Controls Plan. No later than 180 days} after the ROD is signed, DOE shall revise and submit to EPA and DEQ for review and approval the INL Sitewide Institutional Controls Plan. The revised plan will include ICs required by this ROD and specify the implementation and maintenance actions that will be taken, including periodic inspections. The INL Sitewide Institutional Controls Plan is the Agency-approved document that is used by DOE and establishes a consistent approach for implementation of ICs at the INL Site. In accordance with EPA guidance on ICs, the INL Sitewide Institutional Controls Plan has been implemented to address those general requirements needed to successfully implement ICs at all CERCLA sites. Those general requirements and controls in the INL Sitewide Institutional Controls Plan include 
- Roles and responsibilities for IC implementation

- $\quad$ Listing of DOE-controlled INL Site areas with ICs and identification of the ICs

- $\quad$ Agency notification of activities or situations that may interfere with the effectiveness of land use controls or are inconsistent with the land use control or IC objectives and identification and implementation of corrective actions

- $\quad$ Notification regarding transfers of IC-controlled sites, including federal transfers

- $\quad$ Establishment of requirements for Agency concurrence with modification or termination of land use controls

- $\quad$ Performance of annual assessments of ICs and reporting results to the Agencies

- Implementation of a tracking mechanism that identifies land areas under IC control and current and projected land uses at the INL Site.

12.2.4.2 Planned Institutional Controls. The following land use control objectives, followed by the implementation actions/mechanisms, are identified and will be maintained by DOE until modified or discontinued by the Agencies:

1. Ensure that land use within the area designated as "industrial land use" remains industrial and that use of the property for nonindustrial uses such as residential housing, elementary and secondary schools, child care facilities, and playgrounds will be prohibited (DOE-ID 2006c or subsequent revisions).

Implementation Actions/Mechanisms:

a. The INL Sitewide Institutional Controls Plan (DOE-ID 2006c) will continue to require notification to the Agencies before any transfer, sale, or lease of an area with ICs to a federal entity and/or a nonfederal entity (such as a state or local government or private party). DOE will coordinate with the Agencies to ensure that the appropriate controls, such as deed notices and other informational devices, are provided in the conveyance or lease documents and protections are in place to maintain effective ICs.

b. Post warning signs in portions of the area designated as "industrial land use" to caution workers of potential hazards associated with the radiological contamination remaining in the soil where exposure would cause an unacceptable risk.

2. Prohibit use of groundwater for drinking water or irrigation purposes in the portion of the SRPA that exceeds MCLs within the groundwater and drilling IC area (Figure 5-6) until groundwater quality has been restored.

Implementation Actions/Mechanisms:

a. The INL Sitewide Institutional Controls Plan (DOE-ID 2006c) will include controls to prevent the use of groundwater that exceeds MCLs for drinking water or irrigation. 
3. Control drilling of new wells and boreholes within the groundwater and drilling IC area (Figure 5-6) to prevent spread of contamination to the SRPA.

Implementation Actions/Mechanisms:

a. The INL Sitewide Institutional Controls Plan (DOE-ID 2006c) will include a process to review plans for drilling of new wells and boreholes in the perched water or SRPA in those areas exceeding MCLs due to INTEC releases until water quality has been restored (below MCLs). The review and approval of plans for new wells and boreholes by the Agencies will ensure that the drilling techniques and planned use of the well/borehole are appropriate. Specifically, the method of construction of the wells and boreholes will not provide a conduit for accelerated infiltration of contaminants during drilling or thereafter.

4. Control the disturbance of soil in the area designated as industrial land use (soil IC area identified in Figure 4-2) to prevent the potential spread of contaminated soil that exceeds the OU 3-14 RAOs unless prior approval is obtained from the Agencies. Soil disturbances include actions disturbing soil during the course of maintenance, construction, or investigation activities.

Implementation Actions/Mechanisms:

a. $\quad$ The INL Sitewide Institutional Controls Plan (DOE-ID 2006c) process for review of soil disturbances of CERCLA sites by non-CERCLA activities will be updated to require a notice of soil disturbance for maintenance, construction, or investigation activities within the area designated as industrial land use.

5. Maintain the integrity of current or future remedial or monitoring systems.

Implementation Actions/Mechanisms:

a. The INL Sitewide Institutional Controls Plan (DOE-ID 2006c) will include a process to restrict actions or activities that would permanently disrupt or lessen the performance of the low-permeability pavement or the ET/CB.

b. An operations and maintenance plan will be developed to monitor the integrity of and repair the low-permeability pavement and associated drainage system.

c. Monitoring plans will include a mechanism to monitor and maintain the integrity of current or future remedial or monitoring systems.

\subsubsection{No Action Sites}

The selected remedy for 16 sites outside the tank farm boundary is no action under CERCLA. Three of these sites (CPP-125, CPP-126, and CPP-128) had leaks or releases of nonradioactive, nonhazardous steam condensate or service wastewater and, therefore, require no action. The remaining 13 no action sites (CPP-102, CPP-103, CPP-104, CPP-105, CPP-106, CPP-107, CPP-108, CPP-109, CPP-110, CPP-113, CPP-114, CPP-115, CPP-116) are shallow injection wells. Releases associated with these sites do not pose an unacceptable risk to human health or the environment that requires CERCLA remediation or implementation of ICs. Upon finalization of the no action decision, the sites will exit the CERCLA process. The requirements of the State of Idaho Department of Water Resources for abandonment of shallow injection wells and assessment of the petroleum releases will be met, as applicable. 


\subsubsection{Newly Discovered Sites}

If historical releases to the environment are discovered, these sites will be addressed using the new site identification process the Agencies have established for evaluation and inclusion of potential new sites under the FFA/CO. Using this process, a newly identified release is evaluated and decisions are made concerning actions to be taken to address the site. This approach allows new sites with releases to be cleaned up under an existing ROD under certain conditions. These decisions for new sites are based on an evaluation of the information known about the release and the associated risk posed. The following is a summary of the approaches that may be taken for newly identified sites:

1. Sites with no CERCLA contaminants that "exit" CERCLA - If there are no CERCLA contaminants, the site will exit the CERCLA process and will be documented on the new site identification evaluation form that is signed by the Agencies.

2. Sites with no unacceptable risks and decision deferred to OU 10-08 ROD - If the site has CERCLA contaminants but the contaminants pose no unacceptable short-term and/or long-term risk, the "no-action" or "no further action" decision on the site will be documented in the OU 10-08 ROD.

3. Sites with unacceptable risk, contaminants included in an existing ROD, and remediation may be expedited - Remediation may be expedited for sites where the Agencies determine that the CERCLA contaminants are similar to those that have already been addressed in the scope of an existing ROD. In this circumstance, the Agencies may use the regulatory framework for a "Plug-In" or "Analogous Sites" approach for new sites. This approach provides that when new sites meet specific criteria (contaminants included in an existing ROD) and remediation may be performed under that ROD, the sites will be cleaned up in accordance with the ROD's RAOs. The completion of remediation is documented in a remedial action report.

4. Sites with an unacceptable risk and the contaminants are not included in an existing ROD -

If contaminants at a site pose an unacceptable risk but are not included in an existing ROD, a CERCLA removal action may be taken. If additional evaluation is needed prior to taking an action, the site may be further evaluated using the process to be identified in the OU 10-08 ROD.

New sites that are remediated using an existing ROD or a removal action will undergo evaluation during the 5-year review process to assess whether the actions taken are sufficient to protect human health and the environment. To protect workers, the public, and the environment, the ICs for newly identified sites being evaluated will be implemented using the controls in place for similar sites at the INL Site.

\subsection{Estimated Cost for the Selected Remedy}

Tables 12-2 through 12-4 give detailed and summary estimated costs to construct, operate, and maintain the selected remedy (Alternative $2 \mathrm{~b}$ plus additional infiltration controls such as those described in EDF-6868) for OU 3-14 tank farm soil and groundwater. The estimated total cost of the remedy, through the year 2095, is $\$ 14,770,941$ in net present value 2006 dollars. The information in this cost estimate is based on the best available information regarding the anticipated scope of the remedial alternative. Changes in the cost elements are likely to occur as a result of new information and data collected during the engineering design of the remedial alternative. Major changes may be documented in the form of a memorandum in the Administrative Record file, an ESD, or a ROD amendment. This is a rough order-of-magnitude engineering cost estimate that is expected to be within +50 to $-30 \%$ of the actual project cost. 
Table 12-2. Detailed capital cost of the selected remedy.

\begin{tabular}{|c|c|c|}
\hline Description of Capital Cost & $\begin{array}{l}\text { Present Day } \\
\text { Cost (2012) } \\
\end{array}$ & $\begin{array}{l}\text { Present Day } \\
\text { Cost (2035) } \\
\end{array}$ \\
\hline \multicolumn{3}{|l|}{ Remedial design } \\
\hline Remedial design work plan & $\$ 48,000$ & $\$ 48,000$ \\
\hline Remedial action work plan & $\$ 39,500$ & $\$ 39,500$ \\
\hline Engineering design drawings, specifications & $\$ 65,000$ & $\$ 65,000$ \\
\hline Operations and maintenance plan & $\$ 27,500$ & $\$ 27,500$ \\
\hline Miscellaneous environmental documents & $\$ 88,500$ & $\$ 88,500$ \\
\hline Subtotal for Remedial Design & $\$ 268,500$ & $\$ 268,500$ \\
\hline \multicolumn{3}{|l|}{ Remediation/technical support activities } \\
\hline Operational plans & $\$ 104,500$ & $\$ 104,500$ \\
\hline Develop management self-assessment plan & $\$ 28,500$ & $\$ 28,500$ \\
\hline $\begin{array}{l}\text { Develop Operational Readiness Review, provisional } \\
\text { operating authorization, and implementation plan }\end{array}$ & $\$ 28,500$ & $\$ 28,500$ \\
\hline Subtotal for Remediation/Technical Support Activities & $\$ 161,500$ & $\$ 161,500$ \\
\hline \multicolumn{3}{|l|}{ Remedial action } \\
\hline Construction equipment & $\$ 28,000$ & $\$ 28,000$ \\
\hline Drainage ditches and culverts (2035) & & $\$ 144,000$ \\
\hline North tank farm excavation, backfill, disposal (2035) & & $\$ 518,000$ \\
\hline Install infiltration barrier (2012) & $\$ 3,075,000$ & \\
\hline Install infiltration barrier (2035) & & $\$ 120,000$ \\
\hline Install ET/CB cover central tank farm (2035) & & $\$ 2,967,000$ \\
\hline Install ET/CB cover south tank farm (2035) & & $\$ 765,000$ \\
\hline Infiltration controls & $\$ 1,396,806$ & \\
\hline Subtotal for Remedial Action & $\$ 4,499,806$ & $\$ 4,542,000$ \\
\hline \multicolumn{3}{|l|}{ Remedial action report } \\
\hline Final inspection/remedial action report & $\$ 174,500$ & $\$ 174,500$ \\
\hline Subtotal for Remedial Action Report & $\$ 174,500$ & $\$ 174,500$ \\
\hline \multicolumn{3}{|l|}{ Professional/technical services } \\
\hline Project management & $\$ 168,000$ & $\$ 168,000$ \\
\hline Construction management & $\$ 201,500$ & $\$ 201,500$ \\
\hline Subtotal for Professional/Technical Services & $\$ 369,500$ & $\$ 369,500$ \\
\hline Subtotal Capital Cost & $\$ 5,473,806$ & $\$ 5,516,000$ \\
\hline Total Capital Cost & \multicolumn{2}{|c|}{$\$ 10,989,806$} \\
\hline
\end{tabular}


Table 12-3. Detailed operations and maintenance and periodic cost of the selected remedy.

\begin{tabular}{|c|c|c|}
\hline Description of Operation and Maintenance Cost & $\begin{array}{l}\text { Estimated Cost } \\
\text { (Annual) }\end{array}$ & $\begin{array}{c}\text { Extended Cost } \\
\text { (Life of Project) }\end{array}$ \\
\hline \multicolumn{3}{|l|}{ O\&M activities } \\
\hline Extraction, containment & $\$ 86,000$ & \\
\hline Project management & $\$ 10,000$ & \\
\hline Subtotal for O\&M Activities & $\$ 96,000$ & \\
\hline \multicolumn{3}{|l|}{ Surveillance and monitoring } \\
\hline Project management & $\$ 10,000$ & \\
\hline Monitoring, sampling, testing, analysis $(2013,2015,2020,2025 \ldots 2095)$ & $\$ 147,000$ & \\
\hline Subtotal for Surveillance and Monitoring & $\$ 157,000$ & \\
\hline \multicolumn{3}{|l|}{ Infiltration controls } \\
\hline Subtotal for Infiltration Controls & $\$ 240,975$ & \\
\hline \multicolumn{3}{|l|}{ Institutional controls } \\
\hline Site information database & $\$ 3,000$ & \\
\hline Annual IC inspection & $\$ 3,000$ & \\
\hline Project management & $\$ 10,000$ & \\
\hline Subtotal for Institutional Controls & $\$ 16,000$ & \\
\hline Total O\&M Cost & $\$ 509,975$ & $\$ 22,152,961$ \\
\hline \multicolumn{3}{|l|}{ Description of Periodic Cost } \\
\hline \multicolumn{3}{|l|}{ Construction/O\&M activities (periodic) ${ }^{\mathrm{a}}$} \\
\hline Remedy failure or replacement & $\$ 4,000$ & \\
\hline Infiltration barrier maintenance & $\$ 122,000$ & \\
\hline Subtotal for Construction/O\&M Activities (periodic) ${ }^{a}$ & $\$ 126,000$ & \\
\hline \multicolumn{3}{|l|}{ Professional/technical services (5-year reviews) } \\
\hline Subtotal for Professional/Technical Services (5-year reviews) & $\$ 52,000$ & \\
\hline \multicolumn{3}{|l|}{ Update ICs plan (annual) } \\
\hline Subtotal for Update ICs Plan (annual) & $\$ 21,000$ & \\
\hline Total Periodic Cost & $\$ 199,000$ & $\$ 13,137,000$ \\
\hline a. Periodic costs are included in operations and maintenance & & \\
\hline
\end{tabular}

Table 12-4. Summary of cost of the selected remedy.

\begin{tabular}{|l|c|}
\hline \multicolumn{1}{|c|}{ Description of Cost } & Estimated Cost \\
\hline Total Capital Cost & $10,989,806$ \\
\hline Total O\&M Cost & $22,152,961$ \\
\hline Total Periodic Cost & $13,137,000$ \\
\hline TOTAL PROJECT COST IN PRESENT VALUE & $\$ 46,279,767$ \\
\hline TOTAL PROJECT COST IN NET PRESENT VALUE & $\$ 14,771,000$ \\
\hline $\begin{array}{l}\text { a. Present value cost includes an average 19.8\% contingency. } \\
\text { b. Net present value in 2006 dollars. Net present value adjusts the value of a dollar today by the value of that same dollar in the future } \\
\text { after accounting for return and inflation. Estimated accuracy is }+50 \text { to }-30 \% \text {. A } 6.5 \% \text { discount rate used to calculate net present value. }\end{array}$ \\
\hline
\end{tabular}




\subsection{Expected Outcomes of the Selected Remedy}

Following are the expected outcomes of the selected remedy in terms of resulting land and groundwater uses, cleanup levels, and risk reduction achieved as a result of the action:

- Available land use and cleanup levels - The available land use is industrial. Institutional controls, the ET/CB, and/or removal and disposal will protect workers from unacceptable external exposure to contaminated soil, based on the $1 \times 10^{-4}$ risk-based level for an industrial worker. For soil outside the ET/CB, the cleanup level is $11.3 \mathrm{pCi} / \mathrm{g} \mathrm{Cs}-137$ to be met by 2095 in the top $4 \mathrm{ft}$.

- $\quad$ Available groundwater uses and cleanup levels-By 2095, the SRPA near INTEC will be restored to beneficial use as an unrestricted source of drinking water for workers and future residents. The cleanup levels for the SRPA to be met by 2095 are the MCLs, which are $8 \mathrm{pCi} / \mathrm{L}$ for $\mathrm{Sr}-90$ and $4 \mathrm{mrem} / \mathrm{yr}$ for total Sr-90, Tc-99, and I-129. Until the MCLs are met, ICs will prevent use of the portion of the SRPA contaminated from INTEC sources.

- Ecological benefits - The installation of the biobarrier component of the ET/CB will protect biota from internal exposure to unacceptable levels of Cs-137 and Sr-90 and prevent biota from bringing contaminants to the surface. 
12-12 


\section{STATUTORY DETERMINATIONS}

CERCLA requires that statutory determinations are made regarding the selected remedy.

\section{Protection of Human Health and the Environment, Compliance with ARARs, and}

Cost-Effectiveness - The selected remedy for each site has been determined to be protective of human health and the environment through the use of engineering controls and institutional controls to prevent external exposures that exceed $1 \times 10^{-4}$ risk-based levels and ingestion of contaminated groundwater that exceeds MCLs. Current workers will continue to be protected from external exposures exceeding $1 \times 10^{-4}$ risk-based levels to Cs-137 contaminated soil using administrative procedures to control access to the tank farm soil. Future workers will be protected by the ET/CB from external exposure to Cs-137 contaminated soil in the tank farm. The biobarrier will prevent biotic intrusion into the contaminated soil, which will both protect biota from contamination and prevent biota from bringing contamination to the surface.

Restoration of the portion of the SRPA contaminated by INTEC releases to MCLs by 2095 will protect hypothetical future residents from ingesting contaminated groundwater. This will be accomplished by reducing infiltration of precipitation and anthropogenic water to the underlying perched water and SRPA. The selected remedy will not pose unacceptable short-term risks to workers during implementation.

The Agencies believe that the selected remedy's combination of ICs, capping, infiltration controls, and monitoring will provide an overall level of protection comparable to grouting with capping and soil removal with capping at a significantly lower cost.

The remedy complies with ARARs. Table 13-1 lists all ARARs for the selected remedy and provides a brief explanation of how the ARAR applies. This table includes nonbinding criteria that are to-be-considered such as EPA Region 10's IC policy. This policy will be used to guide the development of ICs and their inclusion in the INL Sitewide Institutional Controls Plan (DOE-ID 2006c). In implementing the selected remedy, the Agencies have agreed to consider nonbinding criteria that are to-be-considered. This includes DOE Order 435.1, which protects the public and the environment from radiation and addresses the management of radioactive waste. EPA's policy on ICs is also to-be-considered because contamination would remain in place above levels that would allow for unrestricted use.

It is the Agencies' judgment that the selected remedy is cost-effective and represents a reasonable value for the money spent. In making this determination, the following definition from the NCP was used: "A remedy shall be cost-effective if its costs are proportional to its overall effectiveness" (40 CFR 300.430(f)(1)(ii)(D)) and (40 CFR 300.430(f)). The selected remedy (Alternative 2b plus additional infiltration controls) is the most cost-effective of the alternatives because it is the least costly alternative that satisfies the threshold criteria. When compared to other potential remedial actions, the selected remedy provides the best balance between cost and effectiveness in protecting human health and the environment. It meets long-term effectiveness and permanence criteria while protecting workers in the short term during implementation of the remedy. It provides a potentially greater return on investment than the other alternatives because it provides a similar reduction in risk to the SRPA as grouting and removal but is safer for the remediation workers. The low-permeability pavement is equally protective of the SRPA as an ET/CB, as long as it is maintained, and installing the ET/CB over a flat surface is more cost-effective than installing it in and around operating facilities and over aboveground structures that would protrude through the ET/CB because they would still require access. 
Table 13-1. Summary of applicable or relevant and appropriate requirements for the selected remedy.

\begin{tabular}{|c|c|c|c|c|}
\hline \multirow[b]{2}{*}{$\begin{array}{l}\text { Requirement } \\
\text { (Citation) }\end{array}$} & \multicolumn{3}{|c|}{ ARAR Type } & \multirow[b]{2}{*}{ Comments } \\
\hline & $\begin{array}{l}\text { Action- } \\
\text { Specific }\end{array}$ & $\begin{array}{l}\text { Chemical- } \\
\text { Specific }\end{array}$ & $\begin{array}{l}\text { Location- } \\
\text { Specific }\end{array}$ & \\
\hline \multicolumn{5}{|l|}{ Clean Air Act and Idaho Air Regulations } \\
\hline $\begin{array}{l}\text { "Toxic Substances," IDAPA 58.01.01.161 } \\
\text { "Toxic Air Pollutants, Noncarcinogenic Increments," } \\
\text { IDAPA 58.01.01.585 } \\
\text { "Toxic Air Pollutants, Carcinogenic Increments," } \\
\text { IDAPA 58.01.01.586 } \\
\text { "Environmental Remediation Source," } \\
\text { IDAPA 58.01.01.210.16(a) }\end{array}$ & & A & & $\begin{array}{l}\text { Applies to remediation activities. Compliance with } \\
\text { IDAPA 58.01.01.161 requires that the release of } \\
\text { noncarcinogenic and carcinogenic contaminants into } \\
\text { the air must be estimated in accordance with } \\
\text { IDAPA 58.01.01.210 before start of construction, } \\
\text { controlled, and, as necessary, monitored. If these } \\
\text { increments cannot be met for remediation sources, } \\
\text { compliance with IDAPA 58.01.01.161 will be met in } \\
\text { accordance with IDAPA 58.01.01.210.16(a), } \\
\text { "Environmental Remediation Source." }\end{array}$ \\
\hline $\begin{array}{l}\text { "Ambient Air Quality Standards For Specific Air Pollutants," } \\
\text { IDAPA 58.01.01.577 }\end{array}$ & & A & & $\begin{array}{l}\text { The remediation activities will comply with the } \\
\text { applicable emission standards and will not cause or } \\
\text { significantly contribute to a violation of an ambient } \\
\text { air quality standard. Modeling will be performed if } \\
\text { deemed necessary. }\end{array}$ \\
\hline $\begin{array}{l}\text { "National Emission Standards for Hazardous Air Pollutants," } \\
40 \text { CFR 61.92, "Standard" }\end{array}$ & & A & & $\begin{array}{l}\text { Applies to soil removal and cap construction } \\
\text { activities. Will be met, because emissions will be } \\
\text { below allowable levels. }\end{array}$ \\
\hline $\begin{array}{l}\text { "National Emission Standards for Hazardous Air Pollutants," } \\
40 \text { CFR 61.93, "Emission Monitoring and Test Procedures" }\end{array}$ & A & & & $\begin{array}{l}\text { Applies to soil removal and cap construction } \\
\text { activities. Will be met, because emissions will be } \\
\text { below allowable levels. }\end{array}$ \\
\hline $\begin{array}{l}\text { "National Emission Standards for Hazardous Air Pollutants," } \\
40 \text { CFR 61.94(a), "Compliance and Reporting" }\end{array}$ & A & & & $\begin{array}{l}\text { Applies to soil removal and cap construction } \\
\text { activities. Will be met, because emissions will be } \\
\text { below allowable levels. }\end{array}$ \\
\hline $\begin{array}{l}\text { "Rules for Control of Fugitive Dust," and "General Rules," } \\
\text { IDAPA 58.01.01.650 and 58.01.01.651 }\end{array}$ & A & & & $\begin{array}{l}\text { Applies to soil removal and cap construction } \\
\text { activities. Will be met, because emissions will be } \\
\text { below allowable levels. }\end{array}$ \\
\hline
\end{tabular}


Table 13-1. (continued).

\begin{tabular}{|c|c|c|c|c|}
\hline \multirow[b]{2}{*}{$\begin{array}{l}\text { Requirement } \\
\text { (Citation) }\end{array}$} & \multicolumn{3}{|c|}{ ARAR Type } & \multirow[b]{2}{*}{ Comments } \\
\hline & $\begin{array}{l}\text { Action- } \\
\text { Specific }\end{array}$ & $\begin{array}{l}\text { Chemical- } \\
\text { Specific }\end{array}$ & $\begin{array}{l}\text { Location- } \\
\text { Specific }\end{array}$ & \\
\hline \multicolumn{5}{|l|}{ Idaho Hazardous Waste Management Act } \\
\hline $\begin{array}{l}\text { "Hazardous Waste Determination,” IDAPA 58.01.05.006 } \\
\text { (40 CFR 262.11) }\end{array}$ & A & A & & $\begin{array}{l}\text { Applies to wastes that have been placed, treated, } \\
\text { stored, or are being sent to an off-Site facility for } \\
\text { management. }\end{array}$ \\
\hline “Temporary Units,” IDAPA 58.01.05.008 (40 CFR 264.553) & A & A & & $\begin{array}{l}\text { Applies to wastes that require staging, storage, or } \\
\text { treatment. }\end{array}$ \\
\hline $\begin{array}{l}\text { "Land Disposal Requirements,” IDAPA 58.01.05.011 } \\
\text { (40 CFR 268) }\end{array}$ & A & A & & $\begin{array}{l}\text { Applies to wastes that have been placed, stored, } \\
\text { treated, or are being sent to an off-Site facility for } \\
\text { management. }\end{array}$ \\
\hline $\begin{array}{l}\text { “Alternative LDR Treatment Standards for Contaminated } \\
\text { Soil," IDAPA 58.01.05.011 (40 CFR 268.49) }\end{array}$ & A & A & & $\begin{array}{l}\text { Applies to soil wastes that have been placed, stored, } \\
\text { treated, or are being sent to an off-Site facility for } \\
\text { management. }\end{array}$ \\
\hline \multicolumn{5}{|l|}{ Idaho Ground Water Quality Rule } \\
\hline “Ground Water Quality Rule,” IDAPA 58.01.11 & A & A & & $\begin{array}{l}\text { The State of Idaho Ground Water Quality Rule's } \\
\text { regulated levels of contaminants are equivalent to the } \\
\text { Clean Water Act MCLs. Will be met because Sr-90, } \\
\text { Tc-99, I-129, and nitrate concentrations in the SRPA } \\
\text { will be below applicable State of Idaho groundwater } \\
\text { quality standards in } 2095 \text { and after. }\end{array}$ \\
\hline \multicolumn{5}{|l|}{ Idaho Shallow Injection Well, Monitoring Well, and Borehole Standards } \\
\hline $\begin{array}{l}\text { "Rules and Minimum Standards for the Construction and Use } \\
\text { of Injection Wells in the State of Idaho," IDAPA 37.03.03 }\end{array}$ & A & & & $\begin{array}{l}\text { Applies to the shallow injection wells that are } \\
\text { impacted by the remedy and need to be abandoned. }\end{array}$ \\
\hline “Well Construction Standards Rules,” IDAPA 37.03.09 & A & & & $\begin{array}{l}\text { Applies to wells and boreholes that are impacted by } \\
\text { the remedy and need to be abandoned or modified. }\end{array}$ \\
\hline
\end{tabular}


Table 13-1. (continued).

\begin{tabular}{|l|l|l|l|l|}
\hline \multicolumn{2}{|c|}{$\begin{array}{c}\text { Requirement } \\
\text { (Citation) }\end{array}$} & \multicolumn{2}{|c|}{ ARAR Type } & \multicolumn{1}{|c|}{ Comments } \\
\cline { 2 - 4 } \multicolumn{2}{|l|}{} & $\begin{array}{c}\text { Action- } \\
\text { Specific }\end{array}$ & $\begin{array}{c}\text { Chemical- } \\
\text { Specific }\end{array}$ & $\begin{array}{c}\text { Location- } \\
\text { Specific }\end{array}$ \\
\hline To-Be-Considered Requirements & TBC & & $\begin{array}{l}\text { Applies to radioactive waste generated from } \\
\text { remediation activities. Will be met by disposal in } \\
\text { ICDF or at an ICDF-equivalent on-Site or off-Site } \\
\text { disposal facility. }\end{array}$ \\
\hline $\begin{array}{l}\text { EPA Region 10 Final Policy on the Use of Institutional } \\
\text { Controls at Federal Facilities (EPA 2006e) }\end{array}$ & TBC & & $\begin{array}{l}\text { Applies to tank farm soil during IC period, because } \\
\text { contamination will remain in place after remediation } \\
\text { above levels that allow for unrestricted use and } \\
\text { access. Will be met by IC approach defined in } \\
\text { RD/RA work plan. }\end{array}$ \\
\hline $\begin{array}{l}\text { Key: } \\
\text { A = applicable requirement. } \\
\text { TBC= to be considered. }\end{array}$ & & & \\
\hline
\end{tabular}


Use of Permanent Solutions and Alternative Treatment Technologies to the Maximum Extent Practicable and Preference for Treatment as a Principal Element-The NCP expresses a preference for remedies that use permanent solutions and alternative treatment technologies to the maximum extent practicable to reduce toxicity, mobility, and volume. Most of the $\mathrm{COC}$ are radionuclides that cannot be destroyed through treatment. Management of the contaminated soil will include measures to limit contaminant mobility (e.g., containment). A cost-effective method to separate the contaminants from the soil is not available. As a result, the concentration of radionuclides in the contaminated soil that exceeds the RGs will be reduced only by radioactive decay. Therefore, because treatment for radionuclidecontaminated soil is not found to be practical, those remedies addressing radionuclide-contaminated soil do not satisfy the statutory preference for treatment as a principal element of the remedy. EPA's preference for sites that pose relatively low-level threats or where treatment is impractical is engineering controls, such as containment.

The statutory preference for treatment as a principal element is not satisfied because the selected remedy meets the threshold criteria and protects workers from unacceptable direct exposure to Cs-137 contaminated soil without treatment. Implementation of a treatment technology could result in greater overall risk to workers because of the potential for exposure to alpha radiation and high levels of gamma radiation.

Five-Year Reviews - Section 121(c) of CERCLA (42 USC 9621(c)) and the NCP (40 CFR 300.430(f)(5)(iii)(C)) provide the statutory and legal bases for conducting 5-year reviews. For those sites where contaminants are to be left in place in concentrations in excess of levels that will allow for unlimited use and unrestricted exposure, a review will be conducted at least every 5 years after the initiation of the first remedial action. The statutory 5-year review will ensure that the remedy is still effective in protecting human health and the environment. Additionally, the 5-year review will evaluate such factors as contaminant migration from sites where contamination has been left in place, effectiveness of ICs, and overall effectiveness of the remedial actions. Five-year reviews will be conducted for remediated sites with ICs until it has been determined during a 5-year review that controls and reviews are no longer necessary. In an effort to provide a more comprehensive assessment of CERCLA actions being implemented at the INL Site, the Agencies performed a comprehensive 5-year review in 2006 (DOE-NE-ID 2006b). The next INL Site 5-year review is scheduled for completion in 2011 and will include the review of OU 3-14 activities.

If, during a 5-year review, the existing remedy is found to not be protective of human health or the environment, the Agencies could consider new technologies that were not available at the time of ROD signature. New technologies may be developed in the future that could achieve remediation goals faster, better, or for less cost. The Agencies can amend or modify the ROD through the CERCLA process when necessary to ensure that the remedy is protective and to improve the remedy. 
13-6 


\section{DOCUMENTATION OF SIGNIFICANT CHANGES}

CERCLA Section 117(b) (42 USC 9617(b)) requires that an explanation of significant changes from the preferred alternative originally presented in the Proposed Plan be provided in the ROD (42 USC 9601, Public Law 99-499). There are no significant changes. 
14-2 


\section{DECLARATION AND DECISION SUMMARY REFERENCES}

40 CFR 61.92, 2007, "Standard," Code of Federal Regulations, Office of the Federal Register, January 2007.

40 CFR 61.93, 2007, "Emission Monitoring and Test Procedures," Code of Federal Regulations, Office of the Federal Register, January 2007.

40 CFR 61.94, 2007, "Compliance and Reporting," Code of Federal Regulations, Office of the Federal Register, January 2007.

40 CFR 262.11, 2006, "Hazardous Waste Determination," Code of Federal Regulations, Office of the Federal Register, August 2006.

40 CFR 264 Appendix IX, 2006, "Ground-Water Monitoring List," Code of Federal Regulations, Office of the Federal Register, July 2006.

40 CFR 264.553, 2006, “Temporary Units (TU)," Code of Federal Regulations, Office of the Federal Register, July 2006.

40 CFR 265, 2006, "Interim Status Standards for Owners and Operators of Hazardous Waste Treatment, Storage, and Disposal Facilities," Code of Federal Regulations, Office of the Federal Register, July 2006.

40 CFR 268, 2006, "Land Disposal Restrictions," Code of Federal Regulations, Office of the Federal Register, July 2006.

40 CFR 268.49, 2006, "Alternative LDR Treatment Standards for Contaminated Soil," Code of Federal Regulations, Office of the Federal Register, July 2006.

40 CFR 300, 2007, "National Oil and Hazardous Substances Pollution Contingency Plan," Code of Federal Regulations, Office of the Federal Register, March 2007.

40 CFR 300.430, 2007, "Remedial Investigation/Feasibility Study and Selection of Remedy," Code of Federal Regulations, Office of the Federal Register, March 2007.

40 CFR 300.430(f), 2007, "Selection of Remedy," Code of Federal Regulations, Office of the Federal Register, March 2007.

40 CFR 300.430(f)(3), 2007, "Community Relations to Support the Selection of Remedy," Code of Federal Regulations, Office of the Federal Register, March 2007.

40 CFR 300.430(f)(5), 2007, "Documenting the Decision," Code of Federal Regulations, Office of the Federal Register, March 2007.

40 USC, Subtitle I, 1949, "Federal Property and Administrative Services Act," United States Code, June 30, 1949, as amended.

42 USC 7401 et seq., 1999, “Clean Air Act,” United States Code, November 15, 1999, as amended. 
42 USC 9601 et seq., 1980, "Comprehensive Environmental Response, Compensation and Liability Act of 1980 (CERCLA/Superfund)," United States Code, December 11, 1980, as amended.

42 USC 9613, 1980, “Civil Proceedings, United States Code, December 11, 1980, as amended.

42 USC 9617, 1986, "Public Participation," United States Code, October 17, 1986.

42 USC 9620, 1986, “Federal Facilities,” United States Code, October 17, 1986, as amended.

42 USC 9621, 1986, “Cleanup Standards,” United States Code, October 17, 1986.

BOR, 2005, Big Lost River Flood Hazard Study: Idaho National Laboratory, Idaho, Report 2005-2, U.S. Department of the Interior, Bureau of Reclamation, Denver, CO, November 2005.

Bragassa, J. L., 2004a, “Track 1 Decision Documentation Package - No Action Required - Investigation for Shallow Injection Wells CPP-104, CPP-105, CPP-106, CPP-107 and CPP-108 Associated with Fuel Oil Storage Tanks (CPP-701), Operable Unit 3-13, Waste Area Group 3,"

Document ID 24863, Bechtel BWXT Idaho, April 27, 2004.

Bragassa, J. L., 2004b, "Decision Documentation Package - Track 1 Sites CPP-102, CPP-103, CPP-109 and CPP-110 - Shallow Injection Wells Located at INTEC, Operable Unit 3-13, Waste Area Group 3," Document ID 24884, Bechtel BWXT Idaho, March 23, 2004.

DOE, 1991, Draft Environmental Impact Statement for the Siting, Construction, and Operation of New Production Reactor Capacity, DOE/EIS-0144D, U.S. Department of Energy Office of New Production Reactors, April 1991.

DOE, 1995, Settlement Agreement, U.S. Department of Energy, Environmental Management; U.S. Department of the Navy; and Idaho Department of Health and Welfare, October 16, 1995.

DOE, 2002, Idaho High-Level Waste \& Facilities Disposition Final Environmental Impact Statement, DOE/EIS-0287, U.S. Department of Energy, September 2002. Available online at http://www.eh.doe.gov/NEPA/eis/eis0287/0287toc.html.

DOE, 2003, United States Environmental Protection Agency, Idaho Department of Environmental Quality, United States Department of Energy, in the Matter of: the December 04, 2002, Notice of Violation and the December 20, 2002, Statement of Dispute, Agreement to Resolve Dispute, U.S. Environmental Protection Agency, Idaho Department of Environmental Quality, U.S. Department of Energy, February 21, 2003.

DOE, 2005, Supplement Analysis for The Idaho High-Level Waste \& Facilities Disposition Final Environmental Impact Statement, DOE/EIS-0287-SA-01, U.S. Department of Energy, June 2005.

DOE O 435.1, 2001, "Radioactive Waste Management," Change 1, U.S. Department of Energy, August 28, 2001.

DOE O 5400.5, 1993, "Radiation Protection of the Public and the Environment," Change 2, U.S. Department of Energy, January 7, 1993. 
DOE-ID, 1991, Federal Facility Agreement and Consent Order for the Idaho National Engineering Laboratory and Action Plan, Administrative Record No. 1088-06-29-120, U.S. Department of Energy Idaho Operations Office; U.S. Environmental Protection Agency, Region 10; Idaho Department of Health and Welfare, December 1991.

DOE-ID, 1995, Long-Term Land Use Future Scenarios for the Idaho National Engineering Laboratory, DOE/ID-10440, U.S. Department of Energy Idaho Operations Office, August 1995.

DOE-ID, 1997a, Comprehensive RI/FS for the Idaho Chemical Processing Plant OU 3-13 at the INEEL - Part A, RI/BRA Report (Final), DOE/ID-10534, U.S. Department of Energy Idaho Operations Office, November 1997.

DOE-ID, 1997b, Comprehensive RI/FS for the Idaho Chemical Processing Plant OU 3-13 at the INEEL — Part B, FS Report (Final), DOE/ID-10572, U.S. Department of Energy Idaho Operations Office, November 1997.

DOE-ID, 1998, Proposed Plan for Waste Area Group 3 at the Idaho Chemical Processing Plant, Idaho National Engineering and Environmental Laboratory, U.S. Environmental Protection Agency, Idaho Department of Health and Welfare, U.S. Department of Energy Idaho Operations Office, October 1998.

DOE-ID, 1999a, Final Record of Decision, Idaho Nuclear Technology and Engineering Center, Operable Unit 3-13, Idaho National Engineering and Environmental Laboratory, Idaho Falls, Idaho, DOE/ID-10660, Rev. 0, U.S. Environmental Protection Agency, Idaho Department of Environmental Quality, U.S. Department of Energy Idaho Operations Office, October 1999.

DOE-ID, 1999b, Final Scope of Work for the Waste Area Group 3, Operable Unit 3-14, Tank Farm Soil and Groundwater Remedial Investigation/Feasibility Study, DOE/ID-10653, Rev. 0, U.S. Department of Energy Idaho Operations Office, October 1999.

DOE-ID, 2000a, Remedial Design/Remedial Action Work Plan for Group 1 Tank Farm Interim Action, DOE/ID-10772, Rev. 0, U.S. Department of Energy Idaho Operations Office, September 2000.

DOE-ID, 2000b, Operable Unit 3-14 Tank Farm Soil and Groundwater Phase I Remedial Investigation/Feasibility Study Work Plan, DOE/ID-10676, Rev. 0, U.S. Department of Energy Idaho Operations Office, December 2000.

DOE-ID, 2000c, Operable Unit 3-13 Group 2 Closure Evaluation Criteria and Checklist, DOE/ID-10775, Rev. 1, U.S. Department of Energy Idaho Operations Office, October 2000.

DOE-ID, 2001, Comprehensive Remedial Investigation/Feasibility Study for Waste Area Groups 6 and 10 Operable Unit 10-04, DOE/ID-10807, Rev. 0, U.S. Department of Energy Idaho Operations Office, August 2001.

DOE-ID, 2003, Contingent Landfill Closure and Post-Closure Plan for Idaho Nuclear Technology and Engineering Center Tanks WM-182 and WM-183, DOE/ID-10841, Rev. 1, U.S. Department of Energy Idaho Operations Office, September 2003.

DOE-ID, 2004a, Operable Unit 3-14 Tank Farm Soil and Groundwater Remedial Investigation/Feasibility Study Work Plan, DOE/ID-10676, Rev. 1, U.S. Department of Energy Idaho Operations Office, June 2004. 
DOE-ID, 2004b, Explanation of Significant Differences for the Final Record of Decision for the Idaho Nuclear Technology and Engineering Center, Operable Unit 3-13, DOE/ID-11109, Rev. 0, U.S. Department of Energy Idaho Operations Office, January 2004.

DOE-ID, 2004c, Monitoring Report/Decision Summary for Operable Unit 3-13, Group 5, Snake River Plain Aquifer, DOE/ID-11098, Rev. 1, U.S. Department of Energy Idaho Operations Office, December 2004.

DOE-ID, 2004d, Long-Term Monitoring Plan for Operable Unit 3-13, Group 5, Snake River Plain Aquifer, DOE/ID-10783, Rev. 3, U.S. Department of Energy Idaho Operations Office, August 2004.

DOE-ID, 2005, Long-Term Monitoring Plan for Operable Unit 3-13, Group 4 Perched Water, DOE/ID-10746, Rev. 2, U.S. Department of Energy Idaho Operations Office, November 2005.

DOE-ID, 2006a, Operable Unit 3-13, Group 3, Other Surface Soils Remediation Sets 4-6 (Phase II) Remedial Design/Remedial Action Work Plan, DOE/ID-11254, Rev. 0, U.S. Department of Energy Idaho Operations Office, July 2006.

DOE-ID, 2006b, Annual INTEC Water Monitoring Report for Group 4 - Perched Water (2005), DOE/ID-11259, Rev. 0, U.S. Department of Energy Idaho Operations Office, January 2006.

DOE-ID, 2006c, INL Sitewide Institutional Controls Plan, DOE/ID-11042, Rev. 3, U.S. Department of Energy Idaho Operations Office, July 2006.

DOE-ID, 2006d, Operable Unit 3-14 Tank Farm Soil and Groundwater Feasibility Study, DOE/ID-11247, Rev. 0, U.S. Department of Energy Idaho Operations Office, May 2006.

DOE-ID, 2006e, Operation and Maintenance Plan for INTEC Operable Unit 3-13, Group 1, Tank Farm Interim Action, DOE/ID-10771, Rev. 4, U.S. Department of Energy Idaho Operations Office, November 2006.

DOE-NE-ID, 2006a, Operable Unit 3-14 Tank Farm Soil and Groundwater Remedial Investigation/Baseline Risk Assessment, DOE/NE-ID-11227, Rev. 0, U.S. Department of Energy Idaho Operations Office, April 2006.

DOE-NE-ID, 2006b, Five-Year Review of CERCLA Response Actions at the Idaho National Laboratory, DOE/NE-ID-11201, Rev. 1, U.S. Department of Energy Idaho Operations Office, June 2006.

EDF-3943, 2003, "INTEC Injection Well: Summary of Historical Information and Groundwater Quality Trends," Rev. 0, Idaho National Engineering and Environmental Laboratory, Idaho Completion Project, December 2003.

EDF-6868, 2006, "Methods to Reduce Water Infiltration and Recharge of the Northern Shallow Perched Water Zone at INTEC," Rev. 0, Idaho National Laboratory, Idaho Cleanup Project, August 2006.

EPA, 1991, A guide to principal threat and low level threat wastes, Office of Solid Waste and Emergency Response, Washington D.C., Superfund Publication 9380.3-06FS, U.S. Environmental Protection Agency, November 1991. 
EPA, 1992, Supplemental Guidance to RAGS: Calculating the Concentration Term, Office of Solid Waste and Emergency Response, Washington D.C., EPA Publication 9285.7-081, U.S. Environmental Protection Agency, May 1992.

EPA, 2006a, Preliminary Remediation Goals, http://www.epa.gov/region09/waste/sfund/prg/index.html U.S. Environmental Protection Agency, Web page updated March 8, 2006, Web page visited April 24, 2006.

EPA, 2006b, Radionuclide Carcinogenicity Slope Factors, http://www.epa.gov/radiation/heast/index.html, U.S. Environmental Protection Agency, Web page updated March 7, 2006, Web page visited April 24, 2006.

EPA, 2006c, Ecological Soil Screening Levels, http://mountain.epa.gov/ecotox//ecossl, U.S. Environmental Protection Agency, Web page updated April 13, 2006, Web page visited April 24, 2006.

EPA, 2006d, Ecological Soil Screening Levels - Recent Additions, http://mountain.epa.gov/ecotox//ecossl/recent.htm, U.S. Environmental Protection Agency, Web page updated April 13, 2006, Web page visited April 24, 2006.

EPA, 2006e, Region 10 Final Policy on the Use of Institutional Controls at Federal Facilities, U.S. Environmental Protection Agency, available at www.epa.gov, Web page updated May 2006.

ICP, 2004, Evaluation of Tc-99 in Groundwater at INTEC: Summary of Phase 1 Results, ICP/EXT-04-00244, Rev. 0, Idaho National Engineering and Environmental Laboratory, Idaho Completion Project, September 2004.

ICP, 2005a, "2" SWA-106450 Leak North of CPP-1618," New Site Identification, Document ID 1886659, Idaho National Laboratory, Idaho Cleanup Project, April 2005.

ICP, 2005b, “20” SW-NS-110477 Flange Leak East of CPP-601,” New Site Identification, Document ID 1886660, Idaho National Laboratory, Idaho Cleanup Project, April 2005.

ICP, 2005c, “4” SWA-100532 Leak Near the Intersection with 8" SWN-3001," New Site Identification, Document ID 24920, Idaho National Laboratory, Idaho Cleanup Project, April 2005.

ICP, 2005d, "WM-184 CPP Tank Farm Containment Vault Potential Release," Document ID 24908, Idaho National Laboratory, Idaho Cleanup Project, June 2005.

ICP, 2006a, Proposed Plan for Tank Farm Soil and Groundwater at the Idaho Nuclear Technology and Engineering Center, Operable Unit 3-14, RPT-223, Rev. 0, U.S. Department of Energy Idaho Operations Office, U.S. Environmental Protection Agency, Idaho Department of Environmental Quality, August 2006.

ICP, 2006b, Final Report for the Decontamination and Decommissioning of CPP-627 Remote Analytical Facility, ICP/EXT-06-01145, Rev. 0, Idaho National Laboratory, Idaho Cleanup Project, February 2006.

IDAPA 37.03.03, 2003, "Rules and Minimum Standards for the Construction and Use of Injection Wells in the State of Idaho," Idaho Administrative Procedures Act, May 2003. 
IDAPA 37.03.09, 1993, "Well Construction Standards Rules,” Idaho Administrative Procedures Act, July 1993.

IDAPA 58.01.01.161, 1995, “Toxic Substances,” Idaho Administrative Procedures Act, Idaho Department of Environmental Quality, June 1995.

IDAPA 58.01.01.210, 1995, "Demonstration of Preconstruction Compliance with Toxic Standards," Idaho Administrative Procedures Act, Idaho Department of Environmental Quality, June 1995.

IDAPA 58.01.01.210.16, 1995, "Environmental Remediation Source," Idaho Administrative Procedures Act, Idaho Department of Environmental Quality, June 1995.

IDAPA 58.01.01.577, 1994, “Ambient Air Quality Standards For Specific Air Pollutants,” Idaho Administrative Procedures Act, Idaho Department of Environmental Quality, May 1994.

IDAPA 58.01.01.585, 1995, “Toxic Air Pollutants Non-carcinogenic Increments,” Idaho Administrative Procedures Act, Idaho Department of Environmental Quality, June 1995.

IDAPA 58.01.01.586, 2001, “Toxic Air Pollutants Carcinogenic Increments,” Idaho Administrative Procedures Act, Idaho Department of Environmental Quality, March 2001.

IDAPA 58.01.01.650, 1994, "Rules for Control of Fugitive Dust," Idaho Administrative Procedures Act, Idaho Department of Environmental Quality, May 1994.

IDAPA 58.01.01.651, 1994, “General Rules,” Idaho Administrative Procedures Act, Idaho Department of Environmental Quality, May 1994.

IDAPA 58.01.05.006, 2006, "Standards Applicable to Generators of Hazardous Waste," Idaho Administrative Procedures Act, Idaho Department of Environmental Quality, April 2006.

IDAPA 58.01.05.008, 2006, "Standards for Owners and Operators of Hazardous Waste Treatment, Storage and Disposal Facilities," Idaho Administrative Procedures Act, Idaho Department of Environmental Quality, April 2006.

IDAPA 58.01.05.011, 2006, “Land Disposal Restrictions," Idaho Administrative Procedures Act, Idaho Department of Environmental Quality, April 2006.

IDAPA 58.01.11, 1997, “Ground Water Quality Rule,” Idaho Administrative Procedures Act, Idaho Department of Environmental Quality, March 1997.

INEEL, 2001, Infrastructure Long-Range Plan, INEEL/EXT-2000-01052, Rev. 0, Idaho National Engineering and Environmental Laboratory, February 2001. (Note: this document is Official Use Only and its availability is restricted.)

Kreizenbeck, Ronald, EPA, to Warren Bergholz, U.S. DOE, December 4, 2002, "Notice of Violation and Penalty Assessment," CCN 38236.

NBS, 1963, Maximum Permissible Body Burdens and Maximum Permissible Concentrations of Radionuclides in Air and Water for Occupational Exposure, NBS Handbook 69, National Bureau of Standards, U.S. Department of Commerce, Washington, D.C., revised August 1963. 
Public Law 99-499, 1986, "Superfund Amendments and Reauthorization Act of 1986 (SARA)," 100 Statutes 1728, U.S. Environmental Protection Agency, October 17, 1986.

Public Law 108-375, 2004, Ronald W. Reagan National Defense Authorization Act for Fiscal Year 2005, Section 3116, "Defense Site Acceleration Completion," U.S. Department of Energy, January 20, 2004.

Robertson, J. B., R. Schoen, J. T. Barraclough, 1974, The Influence of Liquid Waste Disposal on the Geochemistry of Water at the National Reactor Testing Station, Idaho: 1952-1970, USGS Open-File Report IDO-22053, U.S. Geological Survey, February 1974.

VanHorn, R. L., N. L. Hampton, and R. C. Morris, 1995, Guidance Manual for Conducting Screening Level Ecological Risk Assessments at the INEL, INEL-95/0190, Rev. 0, Idaho National Engineering Laboratory, June 1995.

Vinsome, P. K. W, and G. M. Shook, 1993, "MultiPurpose Simulation,” Journal of Petroleum Science and Engineering, Vol. 9, pp. 29-38, Elsevier Science Publishers B. V., Amsterdam.

Xu, T., E. Sonnenthal, N. Spycher and K. Pruess, 2004, TOUGHREACT User's Guide: A Simulation Program for Non-Isothermal Multiphase Reactive Geochemical Transport in Variably Saturated Geologic Media, LBNL-55460, Lawrence Berkeley National Laboratory, Berkeley, CA, May 2004. 
15-8 


\section{PART 3: RESPONSIVENESS SUMMARY}

\section{RESPONSIVENESS SUMMARY}

The public comment period for the Operable Unit (OU) 3-14 Proposed Plan (DOE-ID 2006a) began August 22, 2006, and ended October 21, 2006, for the receipt of written and oral comments. Public meetings on the OU 3-14 Proposed Plan were conducted in Idaho Falls on August 29, 2006, and Twin Falls on August 30, 2006. Oral and written comments were submitted during the public meetings, and written comments were received during the public comment period required by the Comprehensive Environmental Response, Compensation and Liability Act (CERCLA) §117 (42 USC 9617) and the National Oil and Hazardous Substances Pollution Contingency Plan (NCP) (40 CFR 300.430(f)(5)(iii)(B)). The oral and written comments are available in the Administrative Record for the OU 3-14 remedial investigation/feasibility study (RI/FS) project. The Administrative Record is located in the Idaho National Laboratory (INL)/Idaho Cleanup Project (ICP) Technical Library in Idaho Falls. Additional copies may be viewed at the Albertsons Library on the campus of Boise State University. The Administrative Record can also be accessed on the internet at http://ar.inel.gov.

Responses to the comments are provided in this section. An index to the comments on the OU 3-14 Proposed Plan is provided in Table 16-1.

Table 16-1. Oral and written comments on the OU 3-14 Proposed Plan.

\begin{tabular}{|c|c|c|c|}
\hline Name & Affiliation & Abbreviation & Comment No. \\
\hline \multicolumn{4}{|c|}{ Comments received during public meetings } \\
\hline Dennis Donnelly & Concerned citizen & $\mathrm{DD}$ & $\begin{array}{l}2,3,5,6,8,21,25 \\
27,28,60\end{array}$ \\
\hline Willie Preacher & Shoshone-Bannock Tribes & WP & $21,29,30$ \\
\hline Jeremy Maxand & Snake River Alliance & SRA & See SRA below \\
\hline \multicolumn{4}{|c|}{ Written comments received during public comment period } \\
\hline John Tanner & Coalition 21 & $\mathrm{C} 21$ & $7,23,37,38,44$ \\
\hline Douglas Paddock & Concerned citizen & DP & $\begin{array}{l}21,33,39,46,55 \\
84,87\end{array}$ \\
\hline Xenia Williams & Concerned citizen & XW & $9,30,31,47$ \\
\hline Peter Rickards & Concerned citizen & PR & $\begin{array}{l}3-5,18,20,21,30 \\
41-43,50,52,53 \\
60,61,87\end{array}$ \\
\hline Char Roth & Concerned citizen & $\mathrm{CR}$ & $9,21,29,45$ \\
\hline Bruce Tidwell & Concerned citizen & BT & $8,21,31$ \\
\hline Tom Kennelly & Concerned citizen & $\mathrm{TK}$ & 21,31 \\
\hline William Flannery & INL Citizens Advisory Board & $\mathrm{CAB}$ & $5,39,54,63$ \\
\hline Nikki Hixson & Concerned citizen & $\mathrm{NH}$ & $16,21,30$ \\
\hline Torri Lockman & Concerned citizen & $\mathrm{TL}$ & $30,48,49,64$ \\
\hline Mary Woollen & Keep Yellowstone Nuclear Free & YNF & $\begin{array}{l}3-5,8,9,18,21 \\
30,39,41,43,47 \\
65-67,83,85,86\end{array}$ \\
\hline
\end{tabular}


Table 16-1. (continued).

\begin{tabular}{llcc}
\hline \multicolumn{1}{c}{ Name } & Affiliation & Abbreviation & \multicolumn{1}{c}{ Comment No. } \\
\hline Jeremy Maxand & Snake River Alliance & SRA & $5,8,10,15,21,26$, \\
& & & $32,34-36,39-41$, \\
& & & $56-59,63,80,82$, \\
Chuck Brocious & Environmental Defense Institute & EDI & $83,86,87$ \\
& & & $4,5,8,11,13,21$, \\
& & & $65-68,79,81,86$, \\
Roger Turner, Yvette & Shoshone-Bannock Tribes & SBT & 87 \\
Tuell, Kelly Wright, & & & $1,5,9,12,14,17$, \\
Willie Preacher, & & & $19,20,22,24,51$, \\
Blaine Edmo & & & $54,62,63,69-78$, \\
\hline
\end{tabular}

The comments, both oral and written, have been grouped into various subject categories. These categories are characterization, modeling, risk assessment, remedy selection, design, communications and process, tribal issues, and other issues. The comments are summarized and combined where similar comments have been received.

\section{Public Comments and Agency Responses}

\section{Characterization}

Comment 1: The information gathered to date, especially on the subsurface characterization is great. [SBT]

Response: Thank you. The Department of Energy (DOE), the Environmental Protection Agency (EPA), and the Idaho Department of Environmental Quality (DEQ) (collectively referred to as the Agencies) have spent a great deal of time searching historical records, interviewing employees, using process knowledge, identifying and filling data gaps, drilling, and sampling to characterize the nature and extent of the releases.

\section{Modeling}

Comment 2: There is a problem with Strontium and Cesium in Idaho groundwater [inferring that it came from the INL] based on the USGS report 84-4201, which measured these elements in wells near Pocatello. On page 17, this report shows seven of eight wells having levels of Strontium-90 in the groundwater that exceed the drinking water limit, and Cesium-137 levels are comparable. One well analyzed had levels of Strontium-90 roughly eighteen times the drinking water limit. [DD]

Response: The comment refers to data from the former FMC plant (now a Superfund site) in Michaud Flats near Pocatello, Idaho. It is not in the same flow system or aquifer as the INL Site.

The U.S. Geological Survey (USGS) provided a letter that clarifies the data referred to in this comment (Rousseau 2006) and excerpts are included here. The commentor "misunderstood the data contained in the report. Cesium-137 and strontium-90 data were not provided in the report.

Concentrations of gross-beta particle radioactivity were reported (Jacobson 1984) along with gross-alpha particle radioactivity and tritium. Gross-beta particle radioactivity is a measure of the total radioactivity 
given off as beta particles during the radioactive decay process. By convention, laboratories report this radioactivity as if it were given off by one reference radionuclide..."

"The Michaud Flats area is situated south of the Snake River and ground-water flows to the north and northwest and discharges into the Portneuf River. The Michaud Flats area aquifer system includes the Michaud Gravel, the Sunbeam Formation, the Starlight Formation, and the flows of the Bighole Basalt. Flow in the Michaud Flats area aquifer system is separated from flow in the ESRPA by the Snake River. Because the Snake River prevents groundwater flow between the two aquifer systems, contamination in the Michaud Flats area cannot come from the INL."

Comment 3: Several comments were received on the modeling time frame: The Proposed Plan does not analyze the long-term threat of alpha emitters suspended above the aquifer. This long-term analysis looks only until 2095, despite plutonium lasting 240,000 years. Current DOE [Department of Energy] analysis extends only to 2095, which is insufficient. [DD, PR, YNF]

Response: The Agencies evaluated long-lived contaminants, including plutonium (Pu), beyond 2095. The Proposed Plan summarized the results of the baseline risk assessment (BRA) only for contaminants of concern that either have exceeded, or are predicted in the future to exceed, the Idaho Ground Water Quality standards (same as maximum contaminant levels [MCLs]). The alpha-emitters, including plutonium, were not included in the brief modeling summary in the Proposed Plan because they do not, and are not predicted to, exceed MCLs in the aquifer at the Idaho Nuclear Technology and Engineering Center (INTEC). However, modeling for all contaminants of potential concern, including alpha-emitters is discussed in detail in the BRA. Predictive modeling for each contaminant was continued as far out in the future as necessary to capture the peak arrival(s) in the aquifer. Depending on the contaminant, vadose zone model termination dates ranged from 2095 to the year 87,594 and aquifer model termination dates ranged from 2095 to the year 4587. Because Pu-239 has a long half-life (24,000 years, not 240,000 years as stated in the comment), it was evaluated to determine how far in the future the model should run. Although the peak $\mathrm{Pu}-239$ and $\mathrm{Pu}-240$ concentrations were predicted to have occurred in the Snake River Plain Aquifer in 1960 as a result of injection well discharges, the vadose zone model was run out to the year 87,594 because of public concern over these long long-lived contaminants. This ensured that the potential slow transport through the vadose zone over thousands of years was accounted for. The concentrations of alpha-emitters in vadose zone pore water through the year 87,594 were predicted to be so low that they could not result in concentrations above the MCL in the aquifer and, therefore, the aquifer model for $\mathrm{Pu}-239$ and $\mathrm{Pu}-240$ was not run past the year 2095.

Comment 4: Commentors were concerned about the location of the tank farm relative to the floodplain of the Big Lost River. Several commentors stated that INTEC is in the floodplain of the Big Lost River and has been flooded on numerous previous occasions. One commentor stated the area is destined for massive flooding, called 500-year floods, but the long-term analysis looks only until 2095. [PR, YNF, EDI]

Response: The tank farm has never flooded. The area of the tank farm that will be covered by the evapotranspiration cap with capillary biobarrier is outside of the Big Lost River 100-year and 500-year floodplain. The regulatory requirements for facilities in floodplains are in reference to the 100-year flood, which is the predicted maximum flood that is expected to occur once every 100 years. INL has an exhaustive, updated, peer-reviewed flood hazard study and independent analysis of the INL Diversion Dam which shows that the dam is adequate for the 100-year flow (BOR 2005). Nonetheless, flood models were developed assuming that the INL Diversion Dam does not exist when in fact the dam is adequate for flows up to $1 \mathrm{ft}$ of freeboard, which would likely include the 100-year flood. This study concludes that there will be no significant inundation of the tank farm by the 100 -year flood. The modeling and risk assessment evaluated credible scenarios and were done in accordance with EPA guidance. See response 
to Comment 3 for the issue of long-term analysis. The cap needs to remain effective in protecting industrial workers from exposure to contaminated soil for 220 years until the Cs-137 in the soil has decayed to acceptable levels.

Comment 5: Commentors were concerned that the long-term effects from flooding would spread contaminated soils or plumes. Heavy snows and spring thaws could cause the Big Lost River to overflow. Flood waters could travel horizontally under the cap. Commentors were concerned about recharge upstream of the cap and vadose zone recharge below the cap. How can the DOE assure that in the event of flooding, that suspended plutonium and other contaminants will not migrate? Flood water will generate recharge which would flush the contaminated soil into perched zones and eventually into the aquifer. Commentors would like to see information which addresses these concerns. [DD, PR, CAB, YNF, SRA, EDI, SBT]

Response: As stated in response to Comment 4, the tank farm is outside the Big Lost River floodplain. During periods of flow, the Big Lost River loses water through streambed infiltration. This water moves primarily vertically downward, but may also move horizontally along low-permeability horizons. However, perched water monitoring during periods of river flow during 2005 and 2006 has shown that lateral flow of Big Lost River infiltration in the shallow perched zone (depths of 100-150 ft below ground) is limited to the extreme northwest corner of INTEC and does not extend beneath the tank farm. The basis for this conclusion is that water levels in shallow perched monitor wells located more than 1,000 ft away from the river did not rise in response to flow in the Big Lost River. Rather, shallow perched water levels in the vicinity of the tank farm respond mainly to infiltration of snowmelt and rainfall inside INTEC, as well as to clean water releases within the facility perimeter. A detailed analysis of the relative magnitudes of these recharge sources is presented in a report titled Evaluation of Factors Affecting Perched Water Levels at INTEC (DOE-ID 2006b, Appendix C). This report concludes that “... in both 1993 and 2005, upper shallow perched water levels (near the tank farm) appeared to respond to the rapid rise in soil moisture from precipitation infiltration but not to subsequent river flow."

Comment 6: Tectonic activity could destroy the proposed protections. [DD]

Response: New construction at INL is required to be designed to withstand seismic and tectonic events per DOE requirements for risk reduction and protection of workers, the public, and the environment. The level of rigor of the analysis depends upon the risks associated with the planned operations in the facility being constructed. Tectonic hazards were independently evaluated by the Nuclear Regulatory Commission prior to granting the license to store the Three Mile Island (TMI) -2 fuels at INTEC. Capping soil in place has lower associated hazards than does storing TMI-2 fuel.

The closest mapped faults to INTEC are over 13 miles to the west along the northwest boundary of the INL Site. The most recent fault offsets (earthquakes) along these faults occurred greater than 15,000 years ago. The most recent volcanic activity near INTEC occurred 15 miles south of INL at Craters of the Moon approximately 2,000 years ago. The most recent volcanic flows that reached INTEC occurred approximately 200,000 years ago (Helm-Clark et al. 2005, pages 4-4 and 4-5). Therefore, the claim that tectonic activity could destroy the protections during the required time period (220 years for the evapotranspiration cap with capillary biobarrier and 88 years for the low-permeability pavement) is not credible. The selected remedy requires monitoring and a review every 5 years until the risk is at acceptable levels. In the unlikely event of future tectonic activity, disturbance to the cap would be detected through monitoring, and action would be taken to ensure that the remedy is protective. 
Comment 7: It was pointed out that the Sr-90 plume caused by the injection well is receding. The much larger amount of Sr-90 from the tank farm spills has not reached the aquifer in significant amounts after 35 years. The modeling results indicating that it will not travel far when it gets there seem reasonable. [C21]

Response: The Agencies agree with the comment.

Comment 8: Total source term is an enormous amount of contamination that will end up in the Snake River Plain Aquifer (SRPA). [EDI, DD, BT, SRA, YNF]

Response: The statement that all of the source term will end up in the SRPA is incorrect. The two reasons for this are radioactive decay and adsorption of contaminants to solids (such as the alluvium and interbeds). First, consider radioactive decay. The total source term represents the undecayed inventory (at the time of the release to the soil). The two predominant contaminants, strontium-90 (Sr-90) and cesium-137 (Cs-137), have half-lives of 29 and 30 years, respectively. Since the largest release occurred 35 years ago, less than half of the contamination remains. Second, contaminants move through the subsurface at different rates because they adsorb differently to solids. Thus, of the total source term, only a small fraction of the Sr-90 is predicted to end up in the SRPA because much of it adsorbs to the solids. Other contaminants, such as Cs-137, have even greater affinity to the soil, have remained in the soil for 35 years, and are expected to decay in place and never reach the SRPA. Two of the contaminants that leaked into tank farm soil do not adsorb to solids (technetium-99 and nitrate) and have migrated to the aquifer.

Comment 9: Risk modeling of contaminated groundwater and soil movement does not accurately determine if the aquifer will be protected and is not acceptable. Nature and weather conditions of today may change and current modeling may not be accurate in the future. Capping does not fully protect the aquifer and is not the answer to cleanup. [SBT, XW, YNF, CR]

Response: In order to assess risks in the future, groundwater modeling is necessary. The results of groundwater modeling (DOE-NE-ID 2006a, Appendixes A and J, and summarized in Section 8) are used to assess risks in the Baseline Risk Assessment (summarized in DOE-NE-ID 2006a, Sections 6, 7, and 8). In the Feasibility Study (DOE-ID 2006c, Appendix A), the Agencies examined whether a low-permeability pavement would protect the aquifer and determined that a 10-acre low-permeability pavement would meet the objective of protecting the aquifer (DOE-ID 2006c, Section A-5). Although the Agencies try to minimize modeling uncertainty and improve the predictive ability of the model, the Agencies recognize that modeling is only a tool and can be inaccurate or fail to account for unexpected changes in conditions. Therefore, monitoring of the perched water and Snake River Plain Aquifer is a component of the remedy. Because waste will be left in place, the Comprehensive Environmental Response, Compensation and Liability Act (CERCLA) requires that the Agencies conduct 5-year reviews to ensure that the remedy is fully protective of the aquifer. If data indicate that the remedy is not protective, the CERCLA process mandates that the Agencies modify the remedy to ensure protectiveness.

Comment 10: One commentor said that they have a strong bias in favor of contaminant removal based on the importance of the SRPA and uncertainties underlying all modeled risk assessments. [SRA]

Response: The selected remedy will protect human health and the environment and will comply with all applicable or relevant and appropriate requirements. The selected remedy provides the best balance of the seven remaining criteria: long-term effectiveness and permanence; reduction of toxicity, mobility, or volume through treatment; short-term effectiveness; implementability; cost; state/support agency acceptance; and community acceptance. The OU 3-14 Remedial Investigation/Baseline Risk Assessment (Appendix A, Section 10 of DOE-NE-ID 2006a) acknowledges and discusses uncertainties in 
the modeling process. The vadose zone and groundwater model formulation used reasonably conservative estimates of parameters to err on overestimating risk to account for uncertainty. The State of Idaho DEQ, EPA Region 10, and DOE understand and accept the uncertainties inherent in modeling and require ongoing monitoring of the perched water and aquifer and 5-year reviews to confirm the effectiveness of the remedy.

Comment 11: DOE's modeling is fundamentally and deliberately flawed. DOE's own report states "The modeling results indicated that actions on the Tank Farm Soil alone will not meet Snake River Plain Aquifer Remedial Action Objectives." [EDI]

Response: The Agencies disagree with the statement that the modeling is fundamentally and deliberately flawed. The model and model results used to support the Remedial Investigation/Baseline Risk Assessment (summarized in DOE-NE-ID 2006a, Sections 6, 7, and 8, and provided in detail in Appendices A and J) and Feasibility Study (DOE-ID 2006c, Appendix A) were reviewed and approved by EPA and DEQ as being consistent with the scientific methodologies adopted for these purposes by the Agencies. Actions taken on the tank farm soil alone (removing and/or grouting the tank farm soil) will not be protective of the Snake River Plain Aquifer (SRPA) because the real risk to the aquifer is not from the soil but from the strontium-90 that migrated into the perched water system below the alluvium over 35 years ago. That is why the Agencies have included infiltration controls in the selected remedy to reduce flux of contaminants out of the perched water system to the SRPA, which will protect the aquifer. This combination of actions (capping soil to protect workers, reducing infiltration [over a 10-acre area, which is larger than just the contaminated soil], and additional infiltration controls) will meet the SRPA remedial action objectives. The TETRAD model has been reviewed by an independent third party (Martian 2007). This review indicated that TETRAD is comparable to other programs that are used for environmental modeling.

Comment 12: The years for protection and monitoring until the risk is at an acceptable level is based on 7 half-lives. This may equate to 220 years before it is down to an acceptable level. [SBT]

Response: The statement is referring to the radioactive half-life of cesium-137, which is 30 years. After every 30 years, half of the cesium- 137 has decayed and half remains. After 7 half-lives, less than $1 \%$ of the original cesium-137 remains. If no action was taken, unacceptable levels of risk to workers from direct exposure to contaminated soil inside the tank farm boundary would last 220 years. However, once the evapotranspiration cap with capillary biobarrier is constructed, the workers will be protected. Until that time, workers will be protected using administrative controls similar to those currently in place. For groundwater, if no action was taken, unacceptable levels of strontium-90 would remain in the aquifer until the year 2129. The selected remedy will reduce the time until the contaminants in the aquifer are at acceptable levels on or before 2095.

Comment 13: Radioactive contamination in groundwater under INTEC is 60,000 times the EPA drinking water concentrations [maximum contaminant level or MCL]; at RTC, 176,000 times MCLs. Due to close proximity, both of these sources must be considered collectively in making cleanup decisions that will impact the aquifer. [EDI]

Response: The data cited are from over 14 years ago and are from shallow perched water, not the Snake River Plain Aquifer (SRPA). Currently, the maximum contaminant concentrations in SRPA monitoring wells at INTEC are strontium-90 (about $4 \times$ MCL), technetium-99 (about $3 \times$ MCL), and iodine-129 and nitrate (both at concentrations near the MCL). The concentration of chromium in the aquifer at the Reactor Technology Complex (RTC) has decreased from about $2.5 \times$ MCL in 1993 to $1.4 \times$ MCL in 2005 (ICP 2006). This decreasing trend is consistent with the Operable Unit 2-12 (RTC) Record of Decision, which predicted that the concentrations of all contaminants in the aquifer at RTC 
(both radioactive and nonradioactive) would decrease to below the MCLs within 20 years. The INTEC and RTC plumes were addressed together under the OU 3-13 Remedial Investigation/Feasibility Study (RI/FS) (DOE-ID 1997). That study concluded that commingling the RTC and INTEC plumes would not result in additional unacceptable cumulative risk beyond the unacceptable risks already identified for specific individual contaminants in the aquifer.

\section{Risk Assessment}

Comment 14: Rationale needed for use of 1 in 10,000 as approved risk level. Preference is for 1 in $1,000,000$. Some commentors stated that they prefer no risk. [SBT]

Response: The acceptable risk range for site-related exposures under the National Oil and Hazardous Substances Pollution Contingency Plan (NCP) (40 CFR 300) is $10^{-4}$ (1 in 10,000 or 1E-04) to $10^{-6}$ ( 1 in 1,000,000 or 1E-06). The Agencies agree that acceptable risk for OU 3-14 is at the upper end of this range $\left(1 \times 10^{-4}\right)$ based on $(1)$ the conservative nature of the risk assessment, e.g., it is unlikely there will be future industrial re-use of the OU 3-14 soil sites and therefore worker exposure is anticipated to be much less than 40 hours per week for 25 years; (2) use of the $1 \times 10^{-4}$ risk-based level in the OU 3-13 Record of Decision for all Comprehensive Environmental Response, Compensation and Liability Act soil sites at INTEC (which surround OU 3-14); and (3) the isolation of the INL.

Comment 15: The Record of Decision for the tank farm soil should include, for each contaminant of concern [in the risk assessment], what percentage has decayed and what percentage is left. [SRA]

Response: The Record of Decision, although lengthy, is nevertheless a brief overview of the Remedial Investigation/Baseline Risk Assessment, Feasibility Study, and other technical documents and is not intended to contain the same level of detail. These technical documents are available in the Administrative Record. About half of the cesium-137 in the soil has decayed since the major releases in the 1970s. For a future worker in 2095, after 4 half-lives, about $6 \%$ of the cesium-137 will be left and it will be bound to the soil. For strontium-90, 2095 occurs after 4 half-lives, which means that about $94 \%$ of the strontium-90 will have decayed away, with about $6 \%$ remaining. Most of that $6 \%$ will be bound to soil, bound to interbeds, or in perched water. The other contaminants of concern either have long half-lives (technetium-99 and iodine-129) or no half-life (nitrate). These three contaminants essentially travel with groundwater and do not sorb to sediments, so $100 \%$ will be dispersed in groundwater. The model predicts that these three contaminants will meet the maximum contaminant level by 2095 without any remedial action being taken. The modeling does not account for any degradation of nitrate, which could further decrease concentrations over time.

Comment 16: I have known of several people who live in the affected area and have contracted brain tumors. Currently my children are unable to give their infant tap water for the damage that it causes to her intestines. These may or may not be caused by the leakage of hazardous waste into the aquifer, however, wouldn't it be best to err on the side of safety. [NH]

Response: The Agencies are sorry to hear about your family member and the other people mentioned in your comment. The health problems described in your comment could not have been caused by INTEC releases because the portion of the aquifer that is contaminated above drinking water standards from INTEC sources does not extend beyond the INL boundary and, therefore, does not extend to any residential drinking water wells. The Agencies' remediation plan errs on the side of safety for current workers as well as future residents to ensure contamination does not affect off-Site residents or future on-Site residents. 
Comment 17: The Risk Assessment conducted as a part of the WAG [Waste Area Group] 10 Site Investigation several years ago to gain a better understanding of Tribal risk was not utilized in determination of what level of cleanup will be done on each Operable Unit. [SBT]

Response: The Tribes did not specifically mention INTEC, WAG 3, or OU 3-14 in the material provided to the WAG 10 risk assessment team (DOE-ID 2001, Appendix A). During the institutional control period, institutional controls required at this site and the low-permeability pavement and evapotranspiration cap with capillary biobarrier (i.e., capping) will prohibit exposures to any tribal members who are hunting and gathering. After the institutional control period, these caps will prevent exposures to any tribal members who are hunting and gathering. The selected remedy, which combines engineering and institutional controls and prevents unrestricted access to the site and to contaminants of concern until the contaminants have decayed to acceptable levels, is protective of scenarios involving less frequent exposures (such as hunting and gathering) than the worker exposure scenarios. See Tribal Issues.

Comment 18: DOE failed to analyze the pathway of airborne risk if/when Pu reaches the aquifer and is pumped to the surface for irrigation. This is where the inhalation pathway is REALLY of concern, and billions of plutonium particles will be available for public exposure. Avoiding this known and documented exposure pathway is how they incorrectly conclude the alternatives are all equally effective in the long-term. [PR, YNF]

Response: The modeling predicted that plutonium concentrations would always be at least several orders of magnitude below the maximum contaminant level of $15 \mathrm{pCi} / \mathrm{L}$. Estimation of risk associated with inhalation from groundwater pumped to the surface can be assessed using very conservative assumptions. EPA (EPA 2007) evaluates inhalation from fugitive dust and from volatile radionuclides from groundwater at the site. Because plutonium is not volatile, the only pathway of potential concern would be inhalation of fugitive dust. Inhalation of fugitive dust for an irrigation scenario was evaluated in the OU 3-13 Remedial Investigation/Baseline Risk Assessment (DOE-ID 1997) using more conservative assumptions and determined to not pose an unacceptable risk. However, to address the comment, a worst-case risk assessment assuming that (1) groundwater obtained from an area of highest possible contamination is used for irrigation and (2) that all the Pu-239 in this irrigation water is aerosolized, was performed. It showed that risk levels were more than 100 times below the lower end of the National Oil and Hazardous Substances Pollution Contingency Plan (NCP) acceptable risk range of $1 \times 10^{-6}$ (Van Horn 2007).

\section{Remedy Selection}

Comment 19: The Agencies' determination that the tank farm and 12 surrounding acres will remain industrial for the foreseeable future is inconsistent with the limited 100-year institutional control period provided to the Tank Farm by the Idaho High-Level Waste and Facilities Disposition Final Environmental Impact Statement (DOE 2002a). Sr-90 contamination from INTEC in the aquifer will be greater than maximum contaminant levels (MCLs) beyond the 100-yr institutional control period. The institutional control period should represent a date where DOE is fully prepared to have the INL cleaned up, restored, with natural resources protected. [SBT]

Response: The Agencies agree that the Snake River Plain Aquifer must be restored to maximum contaminant levels (MCLs) within a reasonable time period. The Agencies are committed to cleaning up the aquifer in less than 100 years (by 2095 instead of 2107, which is in 88 years). This is reflected in the remedial action objectives (see Section 8 of this Record of Decision). The selected remedy is designed to achieve MCLs in the aquifer by 2095 and be protective of the environment. This is consistent with the Idaho High-Level Waste \& Facilities Disposition Final Environmental Impact Statement, which used 2095 as the assumed end of DOE's institutional control for the purposes of analysis (DOE 2002a). 
The Agencies have agreed that future residential use beyond 2095 for a 16-acre portion of northern INTEC, which includes grouted facilities and underground tanks (71 FR 68811-68813 and 71 FR 68813-68814), is not a reasonable future use scenario. See Tribal Issues.

Comment 20: Institutional monitoring is only for a short duration. [PR, SBT]

Response: The Department of Energy is legally bound to perform the remedial actions set forth in this Record of Decision (ROD), including all required monitoring (see Description of the Selected Remedy in Part 1 of this ROD). That obligation continues until the remedy is complete. Monitoring will continue for as long as waste remains in place that is above risk-based levels, in accordance with the National Oil and Hazardous Substances Pollution Contingency Plan (NCP) and this ROD.

Comment 21: Many commentors request that soil contamination remaining in the CPP-31 alluvial soil be removed, or all the contamination be removed. [DD, WP, DP, PR, CR, BT, TK, NH, YNF, SRA, EDI]

Response: Removing the soil doesn't significantly reduce the risk to the Snake River Plain Aquifer (see response to Comment 11). The risk to groundwater is from strontium-90 that is already in the perched water system and could migrate, and not from contaminants in the soil, which are immobile. Capping the soil protects workers and biota from exposure until the cesium-137 decays and protects the aquifer from contaminant migration out of the perched water system until strontium- 90 decays. Therefore, it would not be prudent to remove soil, with potential for exposing workers during soil removal, to achieve such a minimal risk reduction to hypothetical future residents or workers.

Site closures under CERCLA are risk-based. Given the future industrial land use likely for this area and results of the Baseline Risk Assessment (DOE-NE-ID 2006a), complete removal of hot spot contamination would not significantly reduce risks to human health and the environment beyond the risk reduction achieved by the selected remedy. "Hot spot" soil removal would be hazardous for remediation workers, more difficult to implement, and less cost-effective. Containment and institutional controls are a cost-effective remedy for this site; they will contain the cesium-137 and prevent exposure until it decays to acceptable levels (220 years). Performance monitoring and 5-year reviews will determine whether the remedy is effective and allow for future modification of the remedy, if needed.

The selected remedy will protect human health and the environment and will comply with all applicable or relevant and appropriate requirements (ARARs). The selected remedy provides the best balance of the seven remaining criteria: long-term effectiveness and permanence; reduction of toxicity, mobility, or volume through treatment; short-term effectiveness; implementability; cost; state/support agency acceptance; and community acceptance.

Comment 22: We applaud the amount of cleanup that has been done at the site but the Tribes feel that DOE and the contractors have determined the End State for the INL without any type of consideration from Tribes or stakeholders. The initial discussion [during a DOE presentation in 2002 on the Project Management Plan at a DOE/tribal meeting] gave the Tribes the indication that all of the contamination would be cleaned up or removed. Now it looks like the answer is to cap any areas that may have some contamination in the sub-surface regardless of the levels of contamination. [SBT]

Response: INL doesn't apply a single end-state standard to all contaminated areas. In the case of soil in the vicinity of the INTEC tank farm, the Agencies are agreeing in this Record of Decision to remediate to an industrial standard. The end state includes low-permeability pavement until 2095 for the outer recharge control zone and the evapotranspiration cap with capillary biobarrier on the south and central tank farm. The Performance Management Plan (DOE-ID 2002) outlined DOE's accelerated 
cleanup strategy. That plan indicated that a majority of cleanup decisions would be made by 2012 . Cleanup in this context means remediate. Cleanup decisions are based on achieving acceptable risk-based levels, not necessarily pristine conditions, and options can include, for example, no action, removal, or treatment. Cleanup criteria can be met by containing the waste and monitoring to ensure the remedial action objectives are achieved. The public comment process on the Proposed Plan is the Tribes' and other stakeholders' opportunity to affect the choice of remedial action. See Tribal Issues.

Comment 23: One commentor believes the chosen alternative, $2 b$, is adequate for cleanup of the tank farm soils. The commentor would not recommend anything more extensive. [C21]

Response: The Agencies agree that Alternative 2b is adequate for cleanup of tank farm soil.

Comment 24: After attending and listening to the presentations on the Operable Unit 3-14, on the Tank Farms Soils and Groundwater Cleanup, I am fully supportive of the efforts of Idaho DOE to continue to clean up the subsurface and surface contamination. Unfortunately, the total lack of environmental regulation back in the 1940s-1990s has resulted in expensive cleanup that impacts us all. [SBT]

Response: Thank you for requesting the briefing. It was very helpful for the Agencies in understanding your concerns and they appreciate the opportunity to discuss the project and answer your questions.

Comment 25: There is too much contamination (listed on Table 1 in the Proposed Plan) to cap and walk away. [DD]

Response: The contamination listed in Table 1 of the Proposed Plan represents the amount of contamination in the waste at the time of release. Radioactive decay has reduced this contamination by more than half. The residual contamination in the soil is not mobile, is tightly bound to the soil, and is decaying in place.

The selected remedy will protect human health and the environment and will comply with all applicable or relevant and appropriate requirements (ARARs). See response to Comment 21.

Comment 26: The only real active effort to stop contamination is to cover the contaminated area so no further downward migration happens. [SRA]

Response: Reducing recharge of the perched water over a larger area (10 acres) has the most significant benefit in stopping downward migration. Additional infiltration controls will be implemented in northern INTEC. Covering the contamination remaining in the alluvial soil is part of the selected remedy.

Comment 27: The Proposed Plan does not take into account the long radioactive lifetimes of strontium and cesium. [DD]

Response: The half-lives of strontium-90 (Sr-90) and cesium-137 (Cs-137) are not considered long (29 and 30 years, respectively). These half-lives are taken into account in all aspects of this project, from modeling the transport of Sr-90 over long periods of time (until the year 2293), assessing risk to workers from direct exposure to Cs-137 (risk is unacceptable for over 220 years if no action is taken), to selecting a remedy designed to (1) protect human health and the environment until the Cs-137 has decayed to acceptable levels and (2) ensure that Sr-90 concentrations in the aquifer are at safe levels for ingestion by future workers and residents. Institutional controls will protect workers and the environment throughout 
the institutional control period, during which time the Snake River Plain Aquifer will be restored to Idaho Ground Water Quality standards (same as maximum contaminant levels). After 2095, the caps will contain the Cs-137 until it decays to acceptable levels.

Comment 28: Wind and wildfire could disperse contaminants and this was not accounted for. [DD]

Response: The Agencies are not sure if the statement is referring to the risk assessment or the remedy and are responding to both issues. The OU 3-13 Baseline Risk Assessment (DOE-ID 1997) evaluated wind dispersion and these results were incorporated into the OU 3-14 Baseline Risk Assessment (DOE-NE-ID 2006a). The soil contamination at OU 3-14 soil sites is not surficial and cannot be dispersed by wind or wildfire. OU 3-14 soil sites inside the tank farm boundary are currently covered by a liner and up to 6 in. of gravel; three sites (CPP-28, CPP-31, and CPP-79) are also covered by asphalt. Most of the leaks and spills occurred below ground. A few minor releases occurred at the surface. Some of these surface releases have been cleaned up and all of them are covered by the liner/gravel. The two sites outside the tank farm boundary are also covered: CPP-15 is covered by a concrete transformer pad, electrical duct banks, and asphalt around the edges and CPP-58 is covered by pavement and asphalt.

The selected remedy includes covering all soil sites with a low-permeability pavement and then covering the central and southern tank farm with an evapotranspiration cap with a capillary biobarrier. Because the contamination is not surficial and the remedy prevents it from becoming surficial in the future, contaminants of concern will not be available for dispersal through wind or wildfire.

Comment 29: It would be cheaper to remove all the waste right now and remove the potential for mishap than monitor it over time. [WP, CR]

Response: The risk is associated with the strontium-90 contamination that migrated into the perched water system below the soil over 30 years ago and not with the immobile contamination remaining in the soil that is decaying in place. Removing the soil would not remove the primary source of mobile strontium-90 in the subsurface because it is located primarily below the soil in the perched water and interbeds. The perched water system is the source of potential future contamination of the Snake River Plain Aquifer, so monitoring would still be required even if the soil was removed. Although cost was considered, cost is only one of the nine criteria used for remedy selection. The selected remedy provides the best balance of the CERCLA criteria.

Comment 30: We remain concerned that DOE has once again chosen the cheapest alternative to treat some of the deadliest of waste. A remote handled extraction plan could provide $\$ 43$ million in high tech clean-up jobs. [YNF, PR, WP, XW, TL, NH]

Response: The State of Idaho, EPA Region 10, and DOE have selected a cost-effective remedy that also protects human health and the environment, complies with all applicable or relevant and appropriate regulations, and best meets balancing criteria. Using the CERCLA balancing criteria, the Agencies selected Alternative $2 \mathrm{~b}$ because it is the most implementable, offers the best short-term effectiveness (protects remediation workers), and is the most cost-effective option (see Section 12.1 of the Record of Decision).

Comment 31: At what point does our government agencies that hash and rehash the problem at INEEL finally take a stand and do the right thing? At 74 I can say without doubt that every time the government does not do the right thing it has to come back and with double the expense. Do it all over again...Dig up the waste, remove it, and eliminate the potential of the waste ever invading the aquifer. This is a no brainer, spend the money and permanently eliminate the problem. I want it all gone from 
above my water supply. You would too. Be honest. Covering it up just postpones the cleanup decision. Then when it's removed it will cost $\$ 50$ million. The DOE has been balking at this for as long as I can remember. The bottom line is - this waste must be removed to protect it from leaching into the aquifer. If we continue to stall we face contaminated water and an ever increasing price tag to do the right thing! [TK, XW, BT]

Response: The Agencies recognize that they have been studying this problem for a long time (the Agencies began investigating some of these sites under CERCLA in 1991, although some sites were investigated earlier under other programs). This is due to the complexity of the Operable Unit 3-14 sites and the challenges the Agencies face with cleanup of these particular sites, contaminants, and contaminated media. However, through the extensive investigations, the Agencies have learned a lot about these sites - the nature and extent of contamination, the fate and transport of contaminants, and the risk - and conducted a detailed evaluation of remedial alternatives. The Agencies have learned that most of the contamination in the soil is immobile (hasn't moved in 35 years) and is not predicted to cause a problem in the groundwater. Digging up the soil does not protect the Snake River Plain Aquifer (SRPA) because the potentially mobile contamination is below the soil. Reducing infiltration will protect the aquifer by preventing the small mobile fraction of strontium- 90 that is already in the perched water system (at depths greater than $100 \mathrm{ft}$ below grade) from migrating to the SRPA in concentrations that would cause Idaho Ground Water Quality standard (same as maximum contaminant level [MCL]) to be exceeded. That is why the Agencies have selected the low-permeability pavement, evapotranspiration cap with capillary biobarrier, and monitoring rather than digging up the soil. Protection of the SRPA is ensured by monitoring of perched water, which will provide early warning of unexpected contamination, and monitoring of the SRPA. The Agencies agree with the commentors that the SRPA must be restored to MCLs. Fortunately, the strontium-90 contaminant plume is entirely on INL property and has not migrated to any off-Site water supplies. The leading edge of the plume is over 7 miles from the southern INL boundary and the plume is shrinking, a trend that the selected remedy is designed to continue until the aquifer is restored.

Comment 32: DOE needs both the infiltration reducing cap [low-permeability pavement] and the worker protection cap [evapotranspiration cap with capillary biobarrier]. There was some talk this evening about doing only the worker protection cap. At the least, there needs to be redundancy in the line of defense between the aquifer and the rain and storm water that drives contaminants into the aquifer. [SRA]

Response: The low-permeability pavement will be installed over the central and south tank farm and maintained until the evapotranspiration cap with capillary biobarrier $(\mathrm{ET} / \mathrm{CB})$ is installed after INTEC closure. The ET/CB will reduce infiltration over the central and south tank farm so that the low-permeability pavement will not be required. The selected remedy does not specify what to do with the low-permeability pavement. Whether to leave the low-permeability pavement in place or remove it prior to installing the ET/CB will be evaluated in remedial design. It would be left in place if it does not interfere with construction and performance of the ET/CB.

Comment 33: The infiltration-reducing cap [low-permeability pavement] requires maintenance. How would this maintenance be done and how would problems be identified and fixed if the worker protection cap $[\mathrm{ET} / \mathrm{CB}]$ is on top of the infiltration-reducing cap? [DP]

Response: Once the evapotranspiration cap with capillary biobarrier $(\mathrm{ET} / \mathrm{CB})$ is placed on top of the low-permeability pavement, the ET/CB performs the same function as the pavement it replaces. Therefore, maintenance of the pavement under the ET/CB is unnecessary. 
Comment 34: If the waste is not removed from the ground, there needs to be a great deal of attention paid to what type of system will require the least amount of maintenance and attention by the government. [SRA]

Response: This evaluation was done in the Feasibility Study (DOE-ID 2006c) and resulted in selection of the evapotranspiration cap with capillary biobarrier (ET/CB) for long-term isolation of the contamination remaining in the central and south tank farm area. The ET/CB is designed to be maintenance-free. However, as part of remedial design, the Agencies plan to determine if the ET/CB should be expanded to cover areas where only a low-permeability pavement is required. The low-permeability pavement requires maintenance to ensure its effectiveness, and DOE is required to ensure its effectiveness until the Snake River Plain Aquifer has been restored to Idaho Ground Water Quality standards (same as maximum contaminant levels).

Comment 35: Take a hard look at long-term maintenance costs for caps. Where have we done this before? What has the success been? What is the annual cost? How much maintenance is actually required compared to the plan? [SRA]

Response: This evaluation was done for the Feasibility Study, including the cost estimates (see Appendix B of DOE-ID 2006c for details on the costs, including projected annual costs). Currently, INL maintains caps on several sites, including the TRA Warm Waste Pond, the Central Facilities Area landfill, the BORAX-I burial ground, and the SL-1 burial ground, and there have been no issues with performance of these caps. Actual costs for maintaining these caps were assessed for the Feasibility Study cost estimates for the selected remedy. It was found that actual maintenance costs have been similar to the planned costs.

Comment 36: Asking a federal agency to commit to maintaining a structure like this of at least 100 years is questionable. DOE's past and current activities when it comes to newly generated waste leave no room for public trust or confidence that they will maintain these caps, which is the only line of defense between the waste and the water. [SRA]

Response: The Record of Decision is a legally binding document that commits DOE to maintain the covers as long as is necessary. That obligation continues until the remedy is complete and includes maintenance of all components of the remedy, including the final low-permeability pavement and evapotranspiration cap with capillary biobarrier. There are many examples of structures that the U.S. Government has maintained for over 100 years. The Agencies have selected monitoring of perched water as a line of defense to ensure the remedy is protective of the aquifer.

Comment 37: If we could count on it being remembered 100 years from now that this was a nuclear site, nothing would need to be done now. In no reasonable scenario could there be a threat beyond INTEC. [C21]

Response: The Agencies are committed to restoring the Snake River Plain Aquifer during the institutional control period, which the Agencies have assumed could end in 2095, regardless of whether the site remains a nuclear site for 100 years. The Agencies agree that there is no threat beyond INTEC under any reasonable future use scenario.

Comment 38: Worker protection cap [ET/CB] does seem rather thick. [C21]

Response: The thickness of the evapotranspiration cap with capillary biobarrier (ET/CB) is a function of the minimum thickness needed for protectiveness plus the extra thickness necessary to create the gentle slope for drainage. Most of the thickness of the ET/CB at the maximum thickness is grading 
fill, required to achieve a surface slope of 3 to $5 \%$ for drainage. This grading fill adds 3 to $5 \mathrm{ft}$ to the $\mathrm{ET} / \mathrm{CB}$ thickness per $100 \mathrm{ft}$ of horizontal extent.

Comment 39: Several comments question whether or not the caps will sufficiently limit recharge, including from sources outside the capped area. [CAB, DP, SRA, YNF]

Response: Based on research to date, including field observations on the effects of caps in arid environments, the selected remedy will adequately reduce infiltration rates of water and, thereby, the driving force for downward contaminant migration from the perched water system. Vadose zone modeling inputs included measured surface recharge rates over a model domain much larger than the recharge control zone, estimated/measured water from INTEC activities for the duration of activities there, and estimated/measured recharge from Big Lost River flows. Modeling predicted that reducing infiltration to $1-\mathrm{mm} / \mathrm{yr}$ over the 10 -acre area alone would be sufficient to meet maximum contaminant levels in the Snake River Plain Aquifer by 2095. The Agencies recognize the difficulty of achieving a $1 \mathrm{~mm} / \mathrm{yr}$ infiltration rate at an operating facility and are instituting additional recharge controls.

Monitoring and 5-year reviews will assess the effectiveness of the remedy and corrections will be made, if necessary, to ensure continued protectiveness.

Comment 40: ROD should have a full description of institutional controls (which include public information) and their anticipated time span. [SRA]

Response: In response to this comment, the Agencies provided details on institutional controls in this ROD (Section 12.2.4). Institutional controls and their time spans will be further developed during remedial design/remedial action $(\mathrm{RD} / \mathrm{RA})$ to ensure that the remedial action objectives are met. The RD/RA documents and 5-year review documents, which will provide details on the remedy's effectiveness, will be available to the public in the Administrative Record. The Administrative Record can be found on the web at http://ar.inel.gov.

Comment 41: Whenever we hear about cleanup projects, we always hear about what can't be done due to risk to workers. [SRA, PR, YNF]

Response: It could be done, but removing the contaminated soil will not reduce the contamination in the perched water and interbeds that threatens groundwater. It would not be prudent to potentially expose current workers to contamination during soil removal for such a minimal risk reduction to hypothetical future residents or workers. Short-term effectiveness (e.g., worker protection) is one of the required CERCLA evaluation criteria. DOE places a high priority on worker protection, short-term effectiveness, and all other CERCLA criteria used in selecting the remedy.

Comment 42: The DOE is incorrectly analyzing the true impacts of the alternatives to avoid revealing the health threat of their cheaper choice. [PR]

Response: Under CERCLA, the baseline health risks are analyzed in the Baseline Risk Assessment (DOE-NE-ID 2006a) to assess the risks if no action is taken, in order to determine whether an action is necessary. Once it was determined that no action would pose an unacceptable risk, the Agencies developed remedial action objectives and remediation goals. The selected alternative must meet these objectives and goals, the threshold criteria of protecting human health and the environment, and all applicable or relevant and appropriate requirements. No additional risk assessment is required for the alternatives as suggested by the comment. Alternative $2 \mathrm{~b}$ meets these criteria and is protective of human health and the environment. Alternatives 3 (includes hot spot removal) and 4 (includes hot spot grouting) are not cost-effective because they do not significantly reduce the overall risk to the aquifer over Alternative $2 \mathrm{~b}$. The baseline risk assessment and the analysis of effectiveness of the alternatives were 
done according to CERCLA and were extensively reviewed. The State of Idaho, EPA Region 10, and DOE agree that these assessments adequately indicate current and future risks to human health and the environment. Monitoring and 5-year reviews will assess remedy effectiveness through 2095.

Comment 43: This INTEC cleanup plan ironically uses the dangers of inhaling plutonium as the excuse to avoid removing the plutonium. DOE claims they are experts at cleanup, and have robots for waste excavation to avoid worker exposure. Dismissing Alternative 3a for harming workers is incorrect as a decision driver. The DOE says that if the waste and soils are exhumed, it would place the workers at a great health risk due to exposure. In other DOE clean-up operations there has been success in utilizing remote handling techniques and DOE has taken great pride in such efforts. If they could commit to such a strategy in this case then the future worries and legacy which extend out into the tens of thousands of years (based on half-life of plutonium which is 24,000 years) would be gone. [PR, YNF]

Response: The risk to groundwater is from strontium-90 that is located in the interbeds and perched water, not the residual and immobile strontium- 90 that has been in the soil for over 35 years. The amount of plutonium does not present an unacceptable risk if left in place, either to workers or to the aquifer. The presence of plutonium in the soil complicates the remedy, but doesn't preclude soil removal. One of the reasons that the Agencies are choosing Alternative $2 b$ is because removing the soil would not significantly reduce the risk to a hypothetical future worker or the aquifer but increases the chance that a current remediation worker could be exposed (gamma radiation and obstructions during excavation are the main concerns, but not the only concerns). Removing the soil is not cost-effective because it is a significant increase in cost over Alternative $2 \mathrm{~b}$ without a significant incremental reduction in overall risk to the aquifer.

Comment 44: It should be mentioned that workers have already done a lot of digging in the tank farm soil when it was much more radioactive. But it seems reasonable to protect workers in the distant future who are unaware of the history. [C21]

Response: Many of the excavations were done in the 1970s (e.g., CPP-27/33, CPP-28). They had planned to excavate in CPP-31 at the same time, but decided to put the line that they were installing in a different place rather than dig into CPP-31. CPP-31 is more complicated than the other sites (i.e., the combination of the contamination depth, the high radioactivity, and the utilities that would have to be excavated through, including the concrete encasement). At CPP-28, they did not dig below the encasement, so workers did not dig into the most highly radioactive soils. Much of the CPP-31 contamination is also below an encasement. The current contractor application of the As Low As Reasonably Achievable principle to control and limit worker exposures is more protective than in the 1970s. Regardless of what transpired in the past with respect to worker exposure, the selected remedy will protect workers in the future. Digging into Site CPP-31 would subject today's workers to unnecessary risk with little risk reduction for hypothetical future workers.

Comment 45: Radioactive contaminants must stay out of the groundwater. This plan puts future workers and residents at risk. [CR]

Response: One of the primary goals of the remedy selected in this Record of Decision is to ensure that the portion of the Snake River Plain Aquifer contaminated by INTEC operations will meet drinking water standards for future residents and workers. The selected remedy will accomplish this through engineered and administrative controls, and monitoring and 5-year reviews to evaluate effectiveness. 
Comment 46: It does not plan for clean water. It plans for sort-of clean water. It represents a compromise based upon percentages and parts per million that have been determined as acceptable levels of toxicity for drinking water. [DP]

Response: The Idaho Ground Water Quality standards are the same numerically as the maximum contaminant levels (MCLs), which are drinking water standards set by EPA (40 CFR 141.62(b) and 40 CFR 141.66). Concentrations of contaminants in drinking water that are less than the MCLs meet EPA's drinking water standards. These standards, set by laws and regulations, are considered safe. The Agencies are obligated to find solutions that meet these protectiveness standards while using taxpayer dollars cost-effectively.

Comment 47: Alternative $2 \mathrm{~b}$ maintains continued risk of contaminant migration through perched water to the aquifer. [We] were assured that the plutonium that is currently mixed in the soils is no longer mobile, nor of "type" that can migrate. Explanations of this, however, have either been incomprehensible or based on questionable modeling assumptions. I do not believe a dirt cap on plutonium will prevent anything leaking into our only water supply. I cannot believe anybody would expect us to accept that premise. To save a bit of money, maybe? [YNF, XW]

Response: The plutonium in the soil is not migrating and has not migrated in 35 years, and this is supported by sampling results for soil, perched water, and the aquifer and a conservative analysis that assumed there was a hypothetical mobile fraction. The cap is not being designed, or intended, to stop plutonium from migrating out of the soil. The State of Idaho, EPA Region 10, and DOE understand and accept the assumptions used in the modeling. However, because models are simply predictive tools, the Agencies include ongoing monitoring of the perched water and Snake River Plain Aquifer and 5-year reviews to confirm the effectiveness of the remedy.

Comment 48: I want my children to feel free to experience Idaho and its beauty as I did as a child. I want them to grow up and not be concerned about issues with water and having cancer. [TL]

Response: The Agencies feel the same way about the beauty of Idaho, the health and welfare of our children, and the importance of a clean water supply. EPA standards are conservatively set to protect human health and the environment. By selecting a remedy that will meet those standards, the Agencies are ensuring protection of human health, the aquifer, and biota. Even if the Agencies were to take no action, there would not be a health threat to off-Site populations or water supplies. The furthest extent of the strontium-90 contaminant plume is on the INL Site, and over 7 miles away from INL's south boundary. However, the Agencies are taking remedial actions to reduce recharge to the perched water in order to restore the aquifer beneath the INTEC facility to drinking water standards.

Comment 49: Think about the long-term effects and the damage that has already been done. [TL]

Response: The Baseline Risk Assessment (DOE-NE-ID 2006a) examines the long-term effects of the contamination that has occurred in the tank farm soil and INTEC groundwater. It looks at the increased risk of cancer for workers exposed to the contaminated soil and hypothetical future residents at INTEC drinking the water. No off-Site effects have occurred from this contamination, which remains on-Site, and no off-Site populations are at risk. The furthest extent of the contaminated plume in the aquifer is receding back toward the INTEC facility, not moving downgradient toward the INL boundary. Workers are being protected from exposure to the contaminated soil and groundwater (INL drinking water wells meet drinking water standards). The Agencies are including monitoring and institutional controls in the remedy to ensure the continuing safety of the water supply and control worker exposures. 
Comment 50: Pump and treat was illegally separated from the rest of the remedies and delayed. This strontium has already leaked into the aquifer and the perched area in between, well below the tank farm. DOE's excuse ("The Agencies did not consider pump and treat of the perched water because it can only be pumped at a few gallons per minute, and the pumping rate cannot be sustained.") is hardly a legitimate reason to refuse to pump it all out and simply CONTAIN it. Pump all perched water out, even if it has to be done slowly, to protect our water. [PR]

Response: The Agencies conducted a thorough analysis of pump and treat for strontium removal from the aquifer. The analysis showed that pump and treat of strontium-90 is not efficient or effectivepump and treat could remove less than 0.1 curie per year of the almost 9,000 curies of strontium- 90 in the subsurface. Over the next 30 years, radioactive decay alone will destroy about 1,500 times as much strontium-90 as pump and treat would. Pumping perched water is ineffective because the perched water can only be pumped at a few gallons per minute; the pumping rate cannot be sustained; the area of influence of each well would be very small, necessitating many wells; and the perched water is still being recharged. Furthermore, pumping perched water to remove strontium-90 would be very ineffective because most of the strontium-90 is not in the water; it is sorbed onto the sediments. On the basis of the detailed evaluations of the alternatives in the Feasibility Study (DOE-ID 2006c), the Agencies have not selected pump and treat. Instead, the Agencies have focused on reducing the volume of perched water using infiltration controls to protect the Snake River Plain Aquifer.

Comment 51: The Tribes would like an assurance that DOE and the current and future M\&O Contractors will do their best to maintain the integrity of the aquifer. [SBT]

Response: DOE's obligation to protect groundwater at the INL Site is inherent in its statutory responsibilities under CERCLA Sections 104 (42 USC 9604) and 120 (42 USC 9620) as delegated to DOE by the President of the United States of America. See Tribal Issues.

Comment 52: DOE has illegally separated the treatment of Sr from their dwelling analysis and focus on alternative options for the soil at the tank farm transfer leak site. [PR]

Response: The Feasibility Study investigated in situ treatment technologies (Table 3-1 and Section 3.2.2.4 of DOE-ID 2006c) and concluded that the technologies were not developed or demonstrated sufficiently to be part of the alternatives that were evaluated in detail. The selected remedy does not use experimental strontium treatment technologies. With regard to treatment of Snake River Plain Aquifer groundwater using pump and treat, which was evaluated in detail in the Operable Unit 3-14 Feasibility Study, the pump and treat of perched water was dismissed for the reasons described in the response to Comment 50. Because pumping would not remove most of the strontium-90 in the perched water system, treatment of extracted perched water would not be effective in meeting remedial action objectives.

Comment 53: DOE's plans to inject acidic polymers (carbopol), which will cover up this strontium problem, are not included in the public cleanup plans. DOE thinks they can avoid true cleanup of strontium- 90 by an experimental temporary injection scheme of an acidic polymer. No one knows what will happen as the $\mathrm{pH}$ changes over time, but it can't be as safe as simply removing the Sr. These plans need to be included for public comment. [PR]

Response: The research the statement is referring to was not part of the Agencies' Proposed Plan for Operable Unit 3-14, and is not part of the selected remedy because the technology is conceptual and not proven. 
Comment 54: Future technology may be developed and we would accept that to be an option for a remedy if it may eliminate or further protect the aquifer. If remedy fails, perform a review to determine if there is new or other technology available to prevent or stop the spread of contamination [SBT, CAB]

Response: The Agencies will review the remedy every 5 years to ensure that it is protective of human health and the environment and is functioning as designed. Furthermore, the Agencies can evaluate whether a remedy change is warranted at any time. If, in the future, the remedy is determined not to be protective, the Agencies can amend the Record of Decision to implement a new technology. If a new technology is developed that could achieve remediation goals faster, better, and for less cost, a process exists under CERCLA to modify the Record of Decision. This flexibility under CERCLA ensures that the Record of Decision can be changed when necessary to ensure that the remedy is protective or to improve the remedy.

\section{Design}

Comment 55: Will the caps be able to withstand extreme weather conditions such as extreme rain, snow, or flood, such as what happened in 1962 and 1969? [DP]

Response: The evapotranspiration cap with capillary biobarrier (ET/CB) is intended to function in a range of average climatic conditions for the INL Site. The tank farm is mounded and did not flood in 1962 or 1969. The area of the tank farm that will be covered by the ET/CB is outside the floodplain of the Big Lost River (BOR 2005). The final cap design will refine the conceptual design to address probabilistic estimates of wind erosion and precipitation based on the required period of performance (the duration of unacceptable risk) to meet all functional and operational requirements.

Comment 56: Native plants in southeastern Idaho have roots that extend below $4 \mathrm{ft}$. How thick will the worker protection cap $[\mathrm{ET} / \mathrm{CB}]$ be at its thinnest point? Do you anticipate ongoing issues with maintenance of the designed grade of the worker protection cap? How will they be addressed? [SRA]

Response: The evapotranspiration cap with capillary biobarrier (ET/CB) incorporates a biobarrier specifically designed to minimize biointrusion by plants, invertebrates, and burrowing animals. Roots will not be able to extend down to the depths reached in native soils. The ET/CB will have a minimum thickness of about $6.5 \mathrm{ft}$. The relatively shallow design grade of 3 to $5 \%$, which is intended to minimize surface soil erosion, is designed to last for the period of performance, without active maintenance. Cap inspections and 5-year reviews will identify any problems with the ET/CB and make corrections as needed.

Comment 57: The risk assessment and feasibility study do not adequately address biotic intruders into contaminated tank farm soil. The commentor is concerned about extent to which intruders will affect both workers and dispersal of radioactive material and expects DOE to evaluate potential impact of intruders (e.g., ants) beyond a general reference. Will contaminated soil generate heat, will heat attract insects or animals? How many intruders will contact contaminated soils and how much contaminated soil will they bring to the surface? In what form? What will happen to contamination once it reaches the surface? What impact will this have on workers and the public? [SRA]

Response: The ecological risk assessment was presented in the Remedial Investigation/Baseline Risk Assessment in Section 7 (DOE-NE-ID 2006a). It analyzes the ecological risk if no action were taken and assumes that the tank farm provides good habitat, which it currently does not (no plants growing through liner and gravel). The shallow tank farm soil is not thermally warm and is not an attractant to invertebrates, including ants. The ecological risk assessment determined that there was an unacceptable risk. As a result, the Agencies selected a biobarrier specifically designed to minimize biointrusion by 
plants, invertebrates, and burrowing animals to protect human health and the environment. The conceptual design of the biobarrier was based on research on biointrusion barriers documented in the Feasibility Study (DOE-ID 2006c).

Comment 58: How far will water from infiltration cap be moved? Will it be possible for infiltration [near the edge of the cap] to come near enough to the control area to influence movement of contaminants [in the soil]? [SRA]

Response: The contaminants in the soil are not mobile and will decay in place. The remedy will reduce infiltration through the 10-acre area to limit transport of strontium-90 from the perched water system to the aquifer. The water will be moved $1,000 \mathrm{ft}$ away to the lined evaporation pond, where it will evaporate. If water were to infiltrate outside the edge of the low-permeability pavement, it should move vertically downward and bypass the contaminated soil. The modeling predicts that infiltrating water outside the 10-acre area will not adversely impact the aquifer. If water moves horizontally under the low-permeability pavement due to wicking, or condenses under the pavement, this should not influence movement of contaminants in the soil because the residual contamination in the soil is immobile and has been there for 35 years. As part of remedial design, engineers will determine whether to install a system to reduce moisture under the pavement.

\section{Communications and Process}

Comment 59: Briefing today [8/30/06] with DEQ and DOE was helpful to understand what the regulators' and DOE's plan is to deal with this problem. [SRA]

Response: Thank you for requesting the briefing. It was very helpful for the Agencies in understanding your concerns and they appreciate the opportunity to discuss the project and answer your questions.

Comment 60: Two commentors stated that an Environmental Impact Statement (EIS) was necessary. One commentor formally requests a full EIS under the National Environmental Policy Act (NEPA). Only with a rigorous analysis of remediation activities versus future threats under NEPA can we have any hope of making a proper decision. Another commentor states that DOE is violating CERCLA and NEPA laws. [DD, PR]

Response: Under DOE's CERCLA/NEPA Policy, established in 1994, DOE relies on the CERCLA process for review of actions to be taken under CERCLA, i.e., no separate NEPA document or NEPA process is ordinarily required. Under this policy, DOE also takes steps to ensure early public involvement in the CERCLA process and makes CERCLA documents available to the public as early as possible.

The basis for DOE's CERCLA/NEPA policy is a determination by the Department of Justice that there is a statutory conflict between NEPA and CERCLA, and that NEPA, as a matter of law, does not apply to CERCLA cleanups. The statutory conflict is that, whereas NEPA allows judicial review (under the Administrative Procedure Act) before an agency takes action, CERCLA seeks to achieve expeditious cleanups and generally bars such "pre-enforcement" review (see CERCLA Section 113(h) (42 USC 9613(h)). A 1995 memorandum from the Assistant Attorney General, Environment and Natural Resources Division, Department of Justice, to DOE, EPA, the Department of Defense, and the Council on Environmental Quality, memorialized agency consensus on DOE's CERCLA/NEPA policy. 
The public comment period and public meetings on the Operable Unit 3-14 Proposed Plan provided the public with an opportunity to examine and comment on remediation alternatives (including the preferred alternative) and participate in the remedy selection process as required under 40 CFR 300.430(f)(3). The Proposed Plan describes the remedial alternatives analyzed, identifies the preferred alternative, and discusses the rationale for its selection. The Remedial Investigation/Baseline Risk Assessment and Feasibility Study were also available during this period.

Comment 61: One commenter said that the plan was illegal. [PR]

Response: The OU 3-14 project (including the Remedial Investigation//Baseline Risk Assessment, Feasibility Study, the Proposed Plan, and this Record of Decision) has proceeded in compliance with CERCLA, the NCP, and the Federal Facility Agreement and Consent Order (DOE-ID 1991) as agreed by the three Agencies.

Comment 62: Commentor requests that DOE provide written response on technical issues raised. [SBT]

Response: This Responsiveness Summary is the written response to all formal comments submitted by members of the public. It is available in the Administrative Record. In fulfillment of the DOE policy on tribal consultation, DOE is placing in the Administrative Record the comments provided by the Tribes and the Agencies' responses, in addition to participating in meetings directly with tribal representatives.

Comment 63: Several commentors would like to see regular groundwater monitoring, reporting, and updates to evaluate the effectiveness of the cap and whether it has affected mobility of contaminants in tank farm soil, and minimized or stopped the spread of contamination. For the first 5 years, DOE and EPA should do a yearly review, with regular reviews every 5 years afterwards. Other commentors requested a yearly update on monitoring results and the status of contaminated plumes. One commentor is confident the designs of the two caps are far more effective than older ones but urged DOE to inform public regularly of extent (concentration and area) of all contaminants of concern in vadose zone, perched water, and the Snake River Plain Aquifer. Findings should be compared to predictions made in the risk assessment. Any problems with caps should be discussed publicly. [SRA, SBT, CAB]

Response: The monitoring and reporting frequency will be specified in the remedial design/remedial action work plan or associated monitoring plans and will be no less frequently than every 5 years. Monitoring reports, which will be available in the Administrative Record, will include concentrations of all contaminants of concern measured in perched water and the Snake River Plain Aquifer. Findings will be compared to predictions made in the risk assessment. Any problems will be included in the reports and the 5-year reviews, which will also be in the Administrative Record. If a problem occurs that would require a fundamental change to the remedy, the Agencies would notify the public and accept public comments as part of a new Proposed Plan.

Comment 64: I feel obligated to express my feeling involving the cover up. [TL]

Response: The Agencies welcome comments from the public. The CERCLA process has been transparent and all documents that support the Agencies' decision are available in the Administrative Record at http://ar.inel.gov. The CERCLA process was followed with involvement of all three Agencies in accordance with regulations and EPA guidance, including public involvement requirements. 
Comment 65: Two commentors stated that DOE mailings describing the project showed a lack of basic information a person would need to make an informed and responsible decision. [YNF, EDI]

Response: The Proposed Plan and Record of Decision are brief overviews of the Remedial Investigation/Baseline Risk Assessment and Feasibility Study and other technical documents and are not intended to contain the same level of detail, because the technical documents are available in the Administrative Record for anyone interested in that level of detail. The Agencies condensed thousands of pages of technical information in the Administrative Record down to 24 pages for the general public. The Agencies attempted to summarize the most important information. The Agencies also mailed a color fact sheet to try to explain the different types of contaminant sources, the contamination that exists today, and where it is in the subsurface. The Remedial Investigation/Baseline Risk Assessment and the Feasibility Study are referenced throughout the Proposed Plan for anyone who would like more technical information. The Agencies appreciate how difficult it is for the general public to read technical documents and, therefore, project people were available at public meetings and provided briefings and conference calls as requested to explain the project and answer questions.

Comment 66: Two commentors stated that waste characterization was downplayed in the Proposed Plan. This persistent \& deliberate trivialization of waste characterization leads the public to believe that there is no major problem. The process was deficient in full disclosure. [YNF, EDI]

Response: Waste characterization data was just one element the Agencies used as a basis in selecting the remedy outlined in this Record of Decision. In the Proposed Plan, the Agencies tried to strike a balance between too much technical detail and too little. The Agencies put critical information on the first page to ensure that the public would realize that (1) the contaminated soil posed an unacceptable risk to unprotected workers, (2) INTEC groundwater would exceed drinking water standards for more than 100 years if no action is taken, and (3) remedial action is required to protect future workers and the Snake River Plain Aquifer. The Proposed Plan also discussed that 12 billion gallons of wastewater had been injected directly into the aquifer down the former INTEC injection well and that the strontium-90 contaminant plume from INTEC is 1-1/2 miles long. The Proposed Plan clearly references the OU 3-14 Remedial Investigation/Baseline Risk Assessment (DOE-NE-ID 2006a) and Feasibility Study (DOE-ID 2006c), both of which provide full disclosure of the nature and extent of contamination, as well as the waste characteristics. Both documents are available to the public in the Administrative Record found at http://ar.inel.gov.

Comment 67: Two commentors provided examples where waste characterization is downplayed. For example, the Proposed Plan states that "strontium-90 exceeds the Idaho Ground Water Quality standard" but fails to say by how much. DOE fails to offer groundwater contaminant levels and corresponding MCLs [maximum contaminant levels]. This data is crucial for the public to fully understand the severity of the problem and draw their own conclusions on appropriate cleanup. This point was brought up in a meeting with the DOE, and the concern was noted but there was no follow-up. [YNF, EDI]

Response: This comment has been addressed in the Record of Decision, Section 5.6 (Table 5-4), which gives current contaminant concentrations that exceed Idaho Ground Water Quality standards (same as MCLs) with the corresponding standard, to facilitate comparison between the two. The Proposed Plan stated that the Snake River Plain Aquifer currently exceeds drinking water standards because that is the threshold dividing what is considered safe and unsafe. Although the Proposed Plan does not state current contaminant concentrations, it gives the maximum predicted concentration for the risk assessment and the corresponding Idaho Ground Water Quality standard. The Proposed Plan also referenced documents that provided more detail, including specific concentrations. The Proposed Plan and Record of Decision are brief overviews of the Remedial Investigation/Baseline Risk Assessment and Feasibility Study and other 
technical documents, which discuss in detail strontium-90 concentration data in comparison to the MCL. All these documents are available in the Administrative Record at http://ar.inel.gov.

Comment 68: One commentor stated that DOE's deficiencies of full disclosure are rampant in public mailings and DEQ and EPA are complicit in this misinformation. The commentor's review of the Administrative Record identified 37,324.56 curies were released from more than 22,990 gallons of leaks, specific information on the maximum soil concentrations and depths, and the estimated 120 gallon release at CPP-15 contained contaminated soils at $778,000 \mathrm{pCi} / \mathrm{g}$. [EDI]

Response: The Agencies did not fail to disclose information. The Remedial Investigation /Baseline Risk Assessment (RI/BRA) (DOE-NE-ID 2006a) contains hundreds of pages of waste characterization information. The Proposed Plan and Record of Decision are brief overviews of the RI/BRA and Feasibility Study and other technical documents and are not intended to contain the same level of detail; the technical documents are available in the Administrative Record for anyone interested in that level of detail. Because only a brief summary can be included in a 24-page Proposed Plan, the Agencies presented information on the contaminant sources for the biggest releases and referenced where specific information can be found. Table 1 in the Proposed Plan compares selected contaminant sources. It shows over 37,000 curies released. The Proposed Plan also mentions the volumes for the most concentrated releases (19,770 gallons mentioned) that included sodium-bearing waste, first-cycle waste, Waste Calcining Facility scrub solution, and process equipment waste. The other releases that were not specifically discussed in the Proposed Plan, but are presented in detail in the RI/BRA, contain much less than $1 \%$ of the radioactivity and contaminant mass released. This includes CPP-15, which contained less than $0.24 \%$ of the total I-129 released and less than $0.005 \%$ of all other radionuclides released at the tank farm. The data cited in the comment was for gross beta, which is not as accurate as the isotope-specific data that were presented in the same table in the RI/BRA, and was at a depth of $10.5 \mathrm{ft}$. Because the contaminated soil is below the depth of exposure for workers, it is the potential mobility of the contamination rather than the concentration that determines risk. The Proposed Plan focused on the mobility and the risk to groundwater under the facility.

\section{Tribal Issues}

Comment 69: The INL lands are within the aboriginal land area of the Shoshone-Bannock Tribes. The Tribes have used the land and waters within and surrounding the INL for fishing, hunting, plant gathering, medicinal, religious, ceremonial, and other cultural uses since time immemorial. These lands and natural resources provided the Tribes their home and way of life. When the Tribes signed the Treaty of Fort Bridger in 1868 with the United States, the Tribes protected their rights to subsistence and traditional activities on the unoccupied lands of the federal government, which includes the INL Site. [SBT]

Response: In addition to responding to Tribal Comment 69, this response addresses common issues raised by the Tribe for the OU 3-14 Proposed Plan and will be referred to as necessary in the responses to Tribal comments.

DOE recognizes that the Shoshone-Bannock Tribes (the Tribes) are concerned that INL is within the aboriginal land area of the Tribes and that historically the land and waters within and surrounding INL were used for fishing, hunting, plant gathering, medicinal, religious, ceremonial, and other cultural uses before the Shoshone-Bannock Reservation (the Reservation) was established. DOE also recognizes there is a distinctive obligation of trust incumbent upon the government in its dealings with the Tribes. The scope of the trust is defined by the specific duties and obligations contained in treaties, agreements, executive orders, or statutes. However, DOE cannot afford the Tribes more rights than the DOE has under the law and implementing regulations. Unless there is a specific duty that has been placed on DOE with 
respect to the Tribes, DOE's trust obligations are discharged by its compliance with general regulations and statutes not specifically aimed at protecting the Tribes. As a mutually agreeable vehicle to discharge our statutory responsibilities and implement applicable federal policies, DOE has entered into the Agreement-in-Principle Between the Shoshone-Bannock Tribes and the United States Department of Energy (DOE 2002b) with the Tribes to define their working relationship and recognize DOE's trust responsibility. For example, in preparing the Operable Unit 3-14 Proposed Plan, DOE's compliance with CERCLA regulations and requirements (e.g., public notice, meetings, and remedy selection) is sufficient to fulfill DOE's trust obligation to the Tribes. At the same time, DOE and its contractors have worked, and will continue to work, with the Tribes to provide input to INL planning and access to INL as necessary or required by the National Historic Preservation Act, the Archaeological Resources Protection Act, the National Environmental Policy Act, the Native American Graves Protections and Repatriation Act, the American Indian Religious Freedom Act, and any other applicable laws and agreements.

CERCLA Section 126 (42 USC § 9626) authorizes the federal government to recognize Indian tribes and afford them substantially the same treatment as states with regard to most CERCLA provisions at locations where tribes have jurisdiction, such as a reservation. This participation includes, but is not limited to, notification to the Tribes of releases, consultation on remedial actions, access to information, and roles and responsibilities under the National Contingency Plan. Since INL is not on the reservation and the Tribes do not otherwise have jurisdiction over INL, this provision does not apply. At federal facilities such as INL, the public participates in the CERCLA process through, among other things, public comment on documents such as the Operable Unit 3-14 Proposed Plan, community interviews, and participation on various advisory boards. Because the Tribes do not have jurisdiction over INL, their rights are on par with those of the public.

The DOE, the State of Idaho, and EPA entered into the Federal Facility Agreement and Consent Order (FFA/CO) to remediate the INL Site. Although the FFA/CO uses the CERCLA process, it integrates the requirements of CERCLA and the Resource Conservation and Recovery Act (including the State counterpart, the Hazardous Waste Management Act). Since the State has jurisdiction to regulate hazardous waste in Idaho, and INL is located in Idaho, the FFA/CO resolved these jurisdictional issues by selecting the CERCLA process as outlined in the National Contingency Plan, and also providing a role in the remediation for Idaho as a regulatory agency. Since INL is outside of the Reservation, the Tribes have no regulatory authority at INL and are not similarly situated with the State. Therefore, there is no legal basis to provide the Tribes with a regulatory role under the FFA/CO.

Article 4 of the Fort Bridger Treaty of 1868 (the Treaty) gives the Tribes a right to hunt on the "unoccupied lands of the United States so long as game may be found thereon." At the same time, in Article 2 of the Treaty, the Tribes agreed to relinquish all title, claims, or rights to aboriginal lands outside the Reservation, including INL. This relinquishment was confirmed in a stipulated judgment before the Indian Claims Commission in Shoshone-Bannock Tribes, Ft. Hall, Idaho et al. v. United States, 19 Ind. Cl. Comm. 3 (1968). Any claims based on such rights would be barred by the stipulated judgment.

For the Tribes to exercise their Treaty hunting right on the INL Site, the land must remain unoccupied and there must be game on the land. While DOE recognizes that the Tribes retained the right under the Treaty to hunt on unoccupied lands on the INL Site, the property encompassing this project is not expected to ever become "unoccupied" such that hunting would arise consistent with the use of the property. As long as the property is fenced and has other indications of occupancy, it will remain occupied. 
Comment 70: Since the creation of the INL activities have damaged the land and natural resources both on- and off-Site. DOE's decisions regarding waste management, remediation, storage, long-term stewardship, and transportation activities must provide for the protection of the Tribes' natural and cultural resources. [SBT]

Response: The DOE has for many years maintained a significant program for protection of cultural resources, including compliance with the Archeological Resources Protection Act, the Native American Graves Protection and Repatriation Act, the National Historic Preservation Act, the American Indian Religious Freedom Act, and other statutes. Pursuant to those statutes, DOE has appropriately involved the Tribes in consultation and other communications on these cultural resource protection efforts. Compliance with these statutes is integrated with all DOE programs, including remedial actions under CERCLA.

DOE-ID has gone well beyond strict compliance with federal cultural resource laws in efforts to avoid impacts to cultural resources located on INL land. The INL Cultural Resource Management Office has developed, for DOE-ID, the INL Cultural Resource Management Plan (CRMP) (DOE-ID 2005) to guide these efforts and tailor the process of cultural resource protection at the INL to comply with federal cultural resource laws, DOE orders, Executive Orders, etc. The CRMP outlines strategies for the protection of all types of cultural resources on the INL Site and was developed over several years with the assistance of the then-Shoshone-Bannock anthropologist and others in her office, now called the Heritage Tribal Office (HeTO). As presented in the CRMP, the 2002 Agreement-in-Principle Between the Shoshone-Bannock Tribes and the United States Department of Energy (AIP) provides a framework for ensuring that the Tribes are involved in INL activities at various levels. A high level of involvement and collaboration is achieved through the INL Cultural Resource Management Office activities, including but not limited to, monthly Cultural Resource Working Group meetings, Quarterly Activity Reports, programmatic archaeological surveys, and yearly archaeological resource monitoring. Through these established communication lines, tribal representatives from HeTO are informed of INL cultural resource compliance activities and provided with opportunities to participate in fieldwork and development of measures that will protect resources of concern to them, particularly during ground-disturbing INL projects. Other CRMP/AIP-driven activities, such as special informational briefings by Idaho Cleanup Project and INL projects and direct delivery of environmental documentation, also provide the Tribes with opportunities to participate in decision-making.

The specific natural resources of interest to the Tribes, related to their treaty right to hunt and fish on "unoccupied lands", have been affected to a very limited extent, primarily by construction of buildings, roads, and utilities. Such construction predated releases of hazardous substances, so there were few surface natural resources at those locations that could be damaged by the subsequent releases. Outside the relatively small areas of land where roads and buildings have been constructed, many within fenced enclosures, approximately $99 \%$ of the 890 square miles of the INL Site is undeveloped and uncontaminated land with some of the most extensive tracts of contiguous natural habitat in Idaho, including both native plants and animals. This preservation has been formalized by establishment of the Sagebrush Steppe Reserve in cooperation with the Bureau of Land Management and the U.S. Fish and Wildlife Service. If, at some future date, portions of the INL Site are returned to the Public Domain, the biological resources that support hunting and food gathering will have been preserved much more than on Public Domain lands that have been open for unrestricted entry by the general public. 
Comment 71: The Tribes are an affected tribe with respect to DOE EM/Clean-up plans and activities, and have a role in EPA and DOE's planning and implementation process for environmental restoration and waste. DOE should work closely with the Tribes on a government-to-government basis, as outlined in the President's Memorandum of April 24, 1994, on Government-to-Government Relations With Native American Tribal Governments (Fed. Reg. Vol. 59, No. 85, May 4, 1994). Part of the responsibility cited in the document is the requirement:

"In carrying out this relationship with the Tribes, the DOE will assess the impact of DOE's plans, projects, programs, activities on tribal trust resources and assure that tribal government rights and concerns are considered during the development of such plans, projects, programs, and activities." [SBT]

Response: DOE-ID, pursuant to the "DOE American Indian and Alaska Natives Tribal Government Policy," dated January 20, 2006 (Bodman 2006), which implements all applicable Presidential guidance, solicited the Tribes' comments on the Operable Unit 3-14 Proposed Plan. In addition to the Proposed Plan, the Tribes received fact sheets on this project. DOE held three briefings with the Tribes on this project and made formal presentations to the INL Citizens Advisory Board (CAB). The Tribes have a DOE tribal liaison who is also a member of the CAB, chair the CAB's INTEC subcommittee, and were in attendance at all CAB briefings and subcommittee conference calls. See Response 70 for a further discussion of DOE's efforts to fulfill its trust responsibility to the Tribes and its government-to-government relations with the Tribes.

Comment 72: DOE, in this project, did not adequately assess the impact to the Tribes, nor did they provide trust responsibility to them, as provided by Fort Bridger Treaty and the above-referenced Presidential Memorandum. Unless the plans are changed to incorporate protection of these Treaty rights the DOE will finalize inadequate Remedial Action Objectives, will fail to provide alternatives that incorporate treaty rights, and then fail to provide adequate weight to the Tribal-based impacts when arriving at the preferred alternative at the Tank Farm (OU 3-14). A section should be added, in the final Plan for OU 3-14 that reflects DOE's consideration of the Tribal Treaty Rights, one that specifically addresses clean-up alternatives at the INL that protect the natural resources consistent with these treaty rights. [SBT]

Response: The remedial action objectives have been developed to incorporate Tribal rights as those rights are or may be applied to INL, as required by law and applicable guidance. As discussed in Response 69, DOE's general trust obligation is discharged by its compliance with general regulations and statutes not specifically aimed at protecting the Tribes. DOE's compliance with CERCLA regulations and requirements (e.g., public notice, meetings, remedy selection) is sufficient to fulfill DOE's trust obligation to the Tribes. The response to Comment 69 also provides information regarding the extent of Tribal hunting and aboriginal rights on INL consistent with Treaty rights.

Comment 73: By adhering to these clean-up policies DOE is, essentially, permanently removing the availability and accessibility of these lands to the Tribes. The archeological record is very clear that the lands at the INL were used historically by the Tribes and consequently they should be restored in the foreseeable future and returned to BLM whereupon the Tribes may exercise their hunting, fishing rights and to travel freely through this land, as they did before DOE took interim possession of the INL. Placing long-term institutional and physical barriers in these lands directly prohibit the future use by the Tribes. In this sense, the DOE has not carried out their trust responsibility to the Tribes, and have not selected alternatives that reflect consideration of restoring the INL lands back to a point where it would be safe and accessible to Tribal members to hunt, fish, and otherwise enjoy the use of their aboriginal territory protected by Treaty Rights. Recommendation: A new section should be added the CERCLA clean-up that changes the RAO's to include one that "addresses Tribal impacts". The Text Chart in the Plan that shows 
Remedial Action Objectives should be changed to reflect the DOE's trust responsibility to the Tribes. [SBT]

Response: As discussed in the response to Comment 69, DOE is required to carry out its trust responsibility consistent with applicable law. In preparing the Operable Unit 3-14 Proposed Plan, DOE's compliance with CERCLA regulations and requirements (e.g., public notice, meetings, and remedy selection) is sufficient to fulfill DOE's trust obligation to the Tribes. As discussed in the response to Comment 69, while DOE recognizes that the Tribes retained the right under the Treaty to hunt on unoccupied lands, the property encompassing this project is not expected to ever become "unoccupied" such that hunting would arise consistent with the use of the property. See the responses to Comments 70 and 71 for additional discussion in regard to DOE's efforts to carry out its trust responsibility to the Tribes.

Comment 74: Tribes preference for approved risk may be with the 1 in 1,000,000 especially since this area is considered as a Tribal resource and some elders may want to re-use these areas. Tribes have the right to gather, hunt and collect on aboriginal territory such as this one. [SBT]

Response: The tank farm, which is the subject of this Proposed Plan, has occupied this specific location for decades. It has long since become unsuitable for hunting activities. The conservative nature of the Operable Unit 3-14 risk assessment bounds the range of activities that would result in Tribal members being exposed to contamination, such as hunting, gathering, and collecting, if this location were unoccupied lands. The selected remedy would be fully protective for these activities, and certainly the risk to Tribal members doing these activities would be significantly less than the risk to workers in conducting excavation or similar activities. See the response to Comment 69 for a discussion of Tribal hunting and aboriginal rights on the INL Site.

Comment 75: Who is considered the regulators? Why aren't the Tribes a part of this bargaining team? Need Tribal involvement. [SBT]

Response: Under the INL Federal Facility Agreement and Consent Order (FFA/CO), selection of the final cleanup decision for the buried waste is the joint responsibility of DOE, EPA, and the State of Idaho. The controlling statute is CERCLA $\S 120$ (42 USC § 9620), which gives oversight of federal facility remedial actions to EPA, with additional involvement by the appropriate state and the appropriate federal agency. Mechanisms for Tribal involvement are discussed in the responses to Comments 69 and 70 .

Comment 76: There has also been a question and a concern regarding the Tribes as being one of the regulators along with the State of Idaho and EPA with important issues at the INL. The INL is located on aboriginal and treaty rights areas of the Shoshone-Bannock Tribes. Radioactive waste shipments routinely travel through the reservation on I-15 Interstate and on the rail to and from the INL. [SBT]

Response: The INL Federal Facility Agreement and Consent Order (FFA/CO) does not envision the Tribes as being one of the regulators along with the State of Idaho and the EPA for CERCLA decisions at INL. However, although the Tribes are not a signatory to the FFA/CO, under the CERCLA process the Tribes' input is solicited through public notice, meetings, and the opportunity to comment on remedy selection. All final cleanup decisions are reached only after evaluating, through public notice and comment, including Tribal comments, the feasibility and safety of a full range of alternatives. Under the FFA/CO, selection of final cleanup remedies for Operable Unit 3-14 and other CERCLA sites is the joint responsibility of DOE, EPA, and the State of Idaho. As discussed in the responses to Comments 69 and 70, DOE has entered into an Agreement-in-Principle with the Tribes that defines their working relationship and recognizes DOE's trust responsibility. Further, EPA as a federal agency also has a trust 
relationship with the Tribes. The CERCLA process has provided for full participation of the Tribes; DOE and EPA, as federal agencies are charged with recognizing and implementing their trust responsibilities to the Tribes for the INL CERCLA cleanup. See the response to Comment 69 for the discussion regarding aboriginal and treaty rights areas of the Tribes. Lastly, the transport of materials, including radioactive and other wastes, on I-15 Interstate and on rail through the Reservation is regulated by the federal government by statutes implemented by the U.S. Department of Transportation.

Comment 77: The protection of the land base and the people is of the highest priority for both the Tribes and DOE. [SBT]

Response: We agree.

Comment 78: It is quite evident that DOE only goes through the "motions" when offering their consultation with the Tribes. It is necessary to demand that a Federal Facilities Agreement be prepared in order to give the Tribes the necessary "clout" in dealing with this Federal Agency; otherwise we will be in the same boat forever, with "token lipservice" offered by DOE. [SBT]

Response: The INL Federal Facility Agreement and Consent Order (FFA/CO) entered into by DOE, EPA, and the State of Idaho governs actions such as the Operable Unit 3-14 Record of Decision. The FFA/CO establishes a formal, three-party process for deciding how to remediate Operable Unit 3-14 and similar sites, pursuant to CERCLA § 120 (42 USC § 9620). All final cleanup decisions are reached only after evaluating, through public notice and comment, the feasibility and safety of a full range of alternatives. Under the FFA/CO, selection of the final cleanup decision for the buried waste is the joint responsibility of DOE, EPA, and the State of Idaho. As discussed in the responses to Comments 69 and 70, DOE has entered into an Agreement-in-Principle with the Tribes that defines their working relationship and recognizes DOE's trust responsibility. The CERCLA process has provided for full participation of the Tribes; DOE and EPA, as federal agencies, are charged with recognizing and implementing their trust responsibilities to the Tribes for the INL CERCLA cleanup. As discussed in the response to Comment 71, DOE has conducted significant consultation and briefings to the Tribes and Tribe members.

\section{Other Issues}

Comment 79: There is significant groundwater intrusion from sumps $(36,633 \mathrm{gal} / \mathrm{yr})$ that collect leaks or other groundwater contributions to waste accumulation outside the original containment area. This data (not disclosed by DOE or IDEQ) indicates serious leaks or equally serious surface/groundwater contributor to INTEC contaminant dispersion into the underlying Snake River Plain Aquifer. [EDI]

Response: The water that is collected in the referenced sumps is rainfall and snowmelt, not groundwater or waste from the tanks. The sump water described in the comment enters the tank vault through unsealed joints in the tank vault ceiling, between the roof beams and panels. The water is pumped out and treated using the Process Equipment Waste evaporator and does not leak into groundwater. The existence of the rainfall and snowmelt, and its effect on contaminant migration, is included in the model. The references where the data can be found were cited in the comment letter and are publicly available. The comment letter provides data from INTEC perched water in 1995 and 2002. Perched water concentrations have decreased over time. More recent data (from 2005) are included in Section 5.6 of this Record of Decision. 
Comment 80: One commentor emphasized that the DOE must learn lessons to avoid future problems like Operable Unit 3-14. [SRA]

Response: Current environmental requirements of the Resource Conservation and Recovery Act (RCRA) that apply to the Tank Farm Facility are designed to prevent these types of releases. All waste transfer lines in the Tank Farm Facility have been upgraded to meet RCRA standards, such as double containment. The Operable Unit 3-14 sites are from old spills and leaks - the last known leak to the environment in the tank farm was in 1986. When design problems were found at the tank farm, DOE performed upgrade projects to correct problems and prevent their recurrence. In addition, DOE also reviewed the entire system configuration at the time of leak discovery and repaired or replaced piping that had similar inferior configuration.

Comment 81: One commentor stated that DOE fails to disclose how much of the INTEC high-level waste tank sediments will be left in tanks, and what specific contaminant concentrations are in the sediments. [EDI]

Response: The performance assessment, where this information was considered in the CERCLA process, was discussed in Section 1.3.12 of the Feasibility Study (DOE-ID 2006c). The requested information on the volume and curies of tank residuals, as well as the estimated radiological contaminant concentrations in the closed tanks, can be found in Basis for 3116 Determination for the Idaho Nuclear Technology and Engineering Center Tank Farm Facility at the Idaho National Laboratory (DOE-NE-ID 2006b), issued November 19, 2006, which can be found at http://apps.em.doe.gov/idwd. There was extensive public review and disclosure related to the Waste Determination and the High-Level Waste and Facilities Disposition Environmental Impact Statement and related Amended Record of Decision (see "Determination under Section 3116 of the Ronald W. Reagan National Defense Authorization Act for Fiscal Year 2005 for the Idaho Nuclear Technology and Engineering Center Tank Farm Facility at the Idaho National Laboratory, Notice of Availability" (71 FR 68813-68814) and the "Amended Record of Decision: Idaho High-Level Waste and Facilities Disposition Final Environmental Impact Statement" (71 FR 68811-68813)). Although not required by Section 3116, DOE also made available the draft 3116 Determination for a 30-day public review and comment period in September 2005 (70 FR 54374-54375). No public comments were received during the comment period; however, comments were subsequently received after the comment period from the State of Idaho and the INL Site Environmental Management Citizens Advisory Board (Hardesty 2006; Kipping 2005; Trever 2006). These comments were considered in preparing the 3116 Basis Document (Provencher 2005; Van Camp 2006a, b). DOE also consulted with the Nuclear Regulatory Commission (NRC) regarding the Waste Determination Pursuant to Section 3116(a) of the National Defense Authorization Act. The DOE also provided other additional information, as requested by the NRC (NRC 2006a); DOE and NRC held public consultation meetings as well as several consultation telephone calls. On October 20, 2006, the NRC issued its "Technical Evaluation Report for the U.S. Department of Energy Idaho National Laboratory Site Draft Section 3116 Waste Determination for Idaho Nuclear Technology and Engineering Center Tank Farm Facility" (NRC 2006b). It is available on the NRC electronic reading room at http://www.nrc.gov with an ADAMS accession number of ML062490108.

Comment 82: Wastes with sodium should not be pumped through piping near contaminated soil, as sodium could remobilize Sr-90, transporting it to groundwater extremely quickly. There needs to be a hard look at piping, joints, boxes, containment - what underground TF piping will be retired, remediated, and what will stay in service and used through the industrial use of the site. What types of liquids are being pumped through those pipes? [SRA] 
Response: The Agencies share your concerns about sodium and its potential to remobilize waste. Idaho Cleanup Project has discontinued use, and initiated closure, of the brine pit near the tank farm. The suggested action - taking a "hard look" at the piping system-is a good idea and has been done. The results of the evaluation dictated which waste transfer lines are being removed from service and which will remain in service. Those that will remain in service have been upgraded to meet Resource Conservation and Recovery Act (RCRA) requirements (double-contained with leak detection/monitoring systems). The waste transfer lines will not handle high-level waste, as that waste no longer exists (it has been calcined). Sodium-bearing waste that is currently stored in the tank farm will be transferred through RCRA-compliant lines in the tank farm to be treated prior to permanent disposal. This piping travels through some of the Operable Unit 3-14 sites, but does not travel through the largest release site, CPP-31. Additional current and future waste will typically be acidic and have much lower concentrations of radionuclides than historical high-level waste. Typical wastes will include decontamination solutions and similar low-level wastes. The lines that will remain in service within the Operable Unit 3-14 boundaries also include utility lines (primarily steam). However, the evaluation of the active piping systems and current liquid characterization is outside the scope of Operable Unit 3-14.

Comment 83: Commentors requested that underground piping in areas near the contaminated soil not be used. One commentor stated that past leaks in valve boxes and transfer pipes could happen again. If there was a failure -- similar to past -- and liquid leaked into already contaminated areas, what is potential for remobilizing strontium and drive waste down into the aquifer? [SRA, YNF]

Response: The current liquid waste system and hypothetical future spills are outside the scope of CERCLA and Operable Unit 3-14. However, the number of lines that will remain in service near the contaminated soil has been evaluated and minimized. The lines that will remain in service, particularly the waste transfer lines, do not have the same configuration as the lines that leaked in the past. The types of piping configurations that leaked in the past (tile encasements, two-piece screwed-together, etc.) have been removed from service and no longer exist. All waste transfer lines that will remain in service are made of stainless steel. All such lines have stainless-steel secondary encasements that have been upgraded to meet current Resource Conservation and Recovery Act requirements. Waste monitoring systems and leak detection systems are improved over historical systems. Due to these system upgrades, the Agencies are confident that another accident, similar to the historical incidents, will not occur.

Comment 84: Continued operation of INTEC facilities poses a risk of further contamination. Leaving INTEC open will lead to prolonged inaction, and only partial cleanup due to operational constraints. INTEC infrastructure should be decommissioned as soon as possible to make way for thorough cleaning of the site. [DP]

Response: The mission of INTEC operations is to ensure that legacy waste is managed and dispositioned properly to protect human health and the environment. Remediation of contaminated areas within INTEC, including cleaning and closing the Tank Farm Facility, tank farm system, and other INTEC facilities; treatment and removal of remaining Tank Farm Facility waste; and retrieval and removal of calcined waste require the continued operation of INTEC and its support facilities and infrastructure (see Section 4 of this Record of Decision). Sudden and abrupt abandonment of INTEC would leave wastes in place that would pose a threat to the environment. Risks of further contamination will be minimized by using processes that meet current environmental regulations and using improved technologies. A planned, sequential cleanup and shutdown of INTEC is the prudent way to proceed to minimize risks to personnel and the environment.

DOE, the State of Idaho, and EPA are committed to the cleanup of Operable Unit 3-14 and the rest of INTEC. There is a regulatory agreement in place between DOE and the State of Idaho that includes cleanup milestones for INTEC. Because it will take time to clean up INTEC, even under DOE's 
accelerated plans, the Agencies are selecting a low-permeability pavement to be installed first. This component of the remedy provides equivalent aquifer protection as the evapotranspiration cap with capillary biobarrier. Comments relating to other cleanups at INTEC are outside of Operable Unit 3-14, but the Agencies have selected a plan that is integrated with these non-CERCLA constraints.

Comment 85: Commentor stated that DOE is obligated by the State of Idaho to remove the plutonium and other contaminated waste. [YNF]

Response: The Agencies are not aware of any requirements as described by the commentor that are applicable to the contamination covered by this Record of Decision. The agreed-to requirements applicable to this remediation are as set forth in the Federal Facility Agreement and Consent Order among DOE, the State of Idaho, and EPA.

Comment 86: Commentors addressed subject matter discussed or presented in documents prepared outside the scope of CERCLA or outside this Operable Unit such as End States and the containment, corrosion rates, seismic standards, potential flooding, waste classification, waste characterization, washing, sampling other media, and grouting or removal related to Resource Conservation and Recovery Act tanks and piping. [EDI, YNF, SRA, SBT]

Response: Comments not specific to the Operable Unit 3-14 project should be addressed to the appropriate program and will not be addressed here. The Agencies carefully evaluated each submitted comment to identify which comments are specific to Operable Unit 3-14 and have responded to those accordingly.

Comment 87: Commentors rendered opinions on other DOE and/or INL programs (Nuclear Energy, Global Nuclear Energy Partnership, continued INTEC operations, other tanks, reprocessing, State of Idaho INL Oversight) unrelated to alternatives discussed in the Proposed Plan, such as the safety for workers in other programs. [SRA, DP, EDI, PR]

Response: The safety and operation of DOE programs other than Operable Unit 3-14 and other comments not directly related to the Operable Unit 3-14 project are beyond the scope of this project. DOE continues to emphasize safety in all aspects of its operations (both nuclear and otherwise). 


\section{RESPONSIVENESS SUMMARY REFERENCES}

40 CFR 141.62, 2004, "Maximum Contaminant Levels for Inorganic Contaminants," Code of Federal Regulations, Office of the Federal Register, June 2004.

40 CFR 141.66, 2000, "Maximum Contaminant Levels for Radionuclides," Code of Federal Regulations, Office of the Federal Register, December 2000.

40 CFR 300, 2006, "National Oil and Hazardous Substances Pollution Contingency Plan," Code of Federal Regulations, Office of the Federal Register, October 2006.

40 CFR 300.430(f)(3), 2007, "Community Relations to Support the Selection of Remedy," Code of Federal Regulations, Office of the Federal Register, January 2007.

40 CFR 300.430(f)(5), 2007, "Documenting the Decision," Code of Federal Regulations, Office of the Federal Register, January 2007.

42 USC 9604, 1980, "Response Authorities," United States Code, December 11, 1980, as amended.

42 USC 9613, 1980, “Civil Proceedings,” United States Code, December 11, 1980, as amended.

42 USC 9617, 1986, "Public Participation," United States Code, October 17, 1986.

42 USC § 9620, 1986, “Federal Facilities,” United States Code, October 17, 1986, as amended.

42 USC § 9626, 1986, “Indian Tribes,” United States Code, October 17, 1986.

70 FR 54374, 2005, "Notice of Availability of Draft Section 3116 Determination Idaho Nuclear Technology and Engineering Center Tank Farm Facility," Federal Register, Vol. 70, No. 177, U.S. Department of Energy, pp. 54374-54375, September 14, 2005.

71 FR 68811, 2006, "Amended Record of Decision: Idaho High-Level Waste and Facilities Disposition Final Environmental Impact Statement," Federal Register. Vol. 71, No. 228, U.S. Department of Energy, pp. 68811-68813, November 28, 2006.

71 FR 68813, 2006, "Determination under Section 3116 of the Ronald W. Reagan National Defense Authorization Act for Fiscal Year 2005 for the Idaho Nuclear Technology and Engineering Center Tank Farm Facility at the Idaho National Laboratory, Notice of Availability," Federal Register, Vol. 71, No. 228, U.S. Department of Energy, pp. 68813-68814, November 28, 2006.

Bodman, S. W., DOE, to Heads of Departmental Elements, DOE, "DOE American Indian and Alaska Natives Tribal Government Policy," January 20, 2006.

BOR, 2005, Big Lost River Flood Hazard Study: Idaho National Laboratory, Idaho, Report 2005-2, U.S. Department of the Interior, Bureau of Reclamation, Denver, CO, November 2005.

DOE, 2002a, Idaho High-Level Waste \& Facilities Disposition Final Environmental Impact Statement, DOE/EIS-0287, U.S. Department of Energy, September 2002. Available online at http://www.eh.doe.gov/NEPA/eis/eis0287/0287toc.html. 
DOE, 2002b, Agreement-in-Principle Between the Shoshone-Bannock Tribes and the United States Department of Energy, December 10, 2002.

DOE-ID, 1991, Federal Facility Agreement and Consent Order for the Idaho National Engineering Laboratory and Action Plan, Administrative Record No. 1088-06-29-120, U.S. Department of Energy Idaho Operations Office; U.S. Environmental Protection Agency, Region 10; Idaho Department of Health and Welfare. Available online at http://ar.inel.gov.

DOE-ID, 1997, Comprehensive RI/FS for the Idaho Chemical Processing Plant OU 3-13 at the INEELPart A, RI/BRA Report (Final), DOE/ID-10534, U.S. Department of Energy Idaho Operations Office, November 1997. Available online at http://ar.inel.gov/.

DOE-ID, 2001, Comprehensive Remedial Investigation/Feasibility Study for Waste Area Groups 6 and 10 Operable Unit 10-04, DOE/ID-10807, Rev. 0, U.S. Department of Energy Idaho Operations Office, August 2001.

DOE-ID, 2002, Environmental Management Performance Management Plan for Accelerating Cleanup of the Idaho National Engineering and Environmental Laboratory, DOE/ID-11006, U.S. Department of Energy Idaho Operations Office, July 2002.

DOE-ID, 2005, Idaho National Laboratory Cultural Resource Management Plan, DOE-ID-10997, Rev. 1, U.S. Department of Energy Idaho Operations Office, October 2005.

DOE-ID, 2006a, Proposed Plan for Tank Farm Soil and Groundwater at the Idaho Nuclear Technology and Engineering Center, Operable Unit 3-14, RPT-223, Rev. 0, U.S. Department of Energy Idaho Operations Office, U.S. Environmental Protection Agency, Idaho Department of Environmental Quality, August 2006.

DOE-ID, 2006b, Annual INTEC Water Monitoring Report for Group 4 - Perched Water (2005), DOE/ID-11259, Rev. 0, U.S. Department of Energy Idaho Operations Office, January 2006.

DOE-ID, 2006c, Operable Unit 3-14 Tank Farm Soil and Groundwater Feasibility Study, DOE/ID-11247, Rev. 0, U.S. Department of Energy Idaho Operations Office, May 2006.

DOE-NE-ID, 2006a, Operable Unit 3-14 Tank Farm Soil and Groundwater Remedial Investigation/Baseline Risk Assessment, DOE/NE-ID-11227, Rev. 0, U.S. Department of Energy Idaho Operations Office, April 2006.

DOE-NE-ID, 2006b, Basis for Section 3116 Determination for the Idaho Nuclear Technology and Engineering Center Tank Farm Facility, DOE/NE-ID-11226, Rev. 0, U.S. Department of Energy Idaho Operations Office, November, 2006.

EPA, 2007 Preliminary Remediation Goals for Radionuclides, http://epa-prgs.ornl.gov/radionuclides/, U.S. Environmental Protection Agency, Web page updated March 11, 2007, Web page visited March 11, 2007.

Hardesty, T., DEQ, letter to M. Gilbertson, DOE, regarding DEQ Review Draft 3116 Determination for INL Tank Farm, August 18, 2006. 
Helm-Clark, C., S. Ansley, T. McLing, and T. Wood, 2005, Borehole and Well Middle-1823 and Its Relationship to the Stratigraphy of the South-Central Idaho National Laboratory, ICP/EXT 05-00790, Rev. 0, Idaho Completion Project, March 2005.

ICP, 2006, Annual Groundwater Monitoring Status Report for Waste Area Group 2 for Fiscal Year 2006, RPT-237, Rev. 1, Idaho Cleanup Project, October 2006.

Jacobson, N. D., 1984, Hydrogeology of Eastern Michaud Flats, Fort Hall Indian Reservation, Idaho: U.S. Geological Survey Water-Resources Investigations Report 84-4201, 31 p.

Kipping, D., INL Site EM Citizens Advisory Board, to R. B. Provencher, DOE-ID, November 16, 2005, "Draft Section 3116 Determination for the Idaho Nuclear Technology and Engineering Center Tank Farm."

Martian, Peter, 2007, Verification and Benchmark Testing of the TETRAD Simulator, Version 12.7ms, RPT-335, Idaho Cleanup Project, January 2007.

NRC, 2006a, "Request for Additional Information on the Draft Section 3116 Determination for Idaho Nuclear Technology and Engineering Center Tank Farm Facility (DOE/NE-ID-11226)," U.S. Nuclear Regulatory Commission, January 10, 2006.

NRC, 2006b, “Technical Evaluation Report for the U.S. Department of Energy Idaho National Laboratory Site Draft Section 3116 Waste Determination for Idaho Nuclear Technology and Engineering Center Tank Farm Facility,” U.S. Nuclear Regulatory Commission, October 2006.

Provencher, R. B., DOE-ID, to D. Kipping, INL Site EM Citizens Advisory Board, December 20, 2005, "Response to Citizens Advisory Board Questions Regarding the Draft Section 3116 Waste Determination for the Idaho Nuclear Technology and Engineering Center Tank Farm (FMDP-MTPP-05-040).”

Rousseau, Joseph P., USGS, letter to Lorie Cahn, CH2M-WG Idaho, September 6, 2006.

Trever, K. E., DEQ, to K. Lockie and X. Yin, DOE, January 17, 2006, "State of Idaho Document Review Report on $\S 3116$ Determination for INL Tank Farm.”

Van Camp, S. G., DOE-ID, to K. E. Trever, DEQ, March 20, 2006(a), “State of Idaho Review Report on Section 3116 Determination for Idaho Tank Farm (FMDP-MTPP-06-005)."

Van Camp, S. G. DOE-ID, to K. E. Trever, DEQ, July 26, 2006(b), "Response State of Idaho Review of Draft 3116 Determination for the Idaho Nuclear Technology and Engineering Center Tank Farm Facility (FMDP-MTPP-06-022)."

Van Horn, Robin L. (Robin.VanHorn@icp.doe.gov), “OU 3-14 ROD - Response to Comment \#19," email to Lorie S. Cahn (Lorie.Cahn@icp.doe.gov), March 12, 2007, CCN 304530. (Note: Due to revisions of draft ROD text that occurred after the date of this email, Comment \#19 is now Comment \#18 in the final ROD.) 
17-4 